\title{
Atrophic gastritis during acid-suppressive therapy with focus on ECL cell hyperplasia and intragastric bacteria
}

Citation for published version (APA):

Sanduleanu, S. (2001). Atrophic gastritis during acid-suppressive therapy with focus on ECL cell hyperplasia and intragastric bacteria. [Doctoral Thesis, Maastricht University]. Universitaire Pers Maastricht. https://doi.org/10.26481/dis.20010928ss

Document status and date:

Published: 01/01/2001

DOI:

10.26481/dis.20010928ss

Document Version:

Publisher's PDF, also known as Version of record

Please check the document version of this publication:

- A submitted manuscript is the version of the article upon submission and before peer-review. There can be important differences between the submitted version and the official published version of record.

People interested in the research are advised to contact the author for the final version of the publication, or visit the DOI to the publisher's website.

- The final author version and the galley proof are versions of the publication after peer review.

- The final published version features the final layout of the paper including the volume, issue and page numbers.

Link to publication

\footnotetext{
General rights rights.

- You may freely distribute the URL identifying the publication in the public portal. please follow below link for the End User Agreement:

www.umlib.nl/taverne-license

Take down policy

If you believe that this document breaches copyright please contact us at:

repository@maastrichtuniversity.nl

providing details and we will investigate your claim.
}

Copyright and moral rights for the publications made accessible in the public portal are retained by the authors and/or other copyright owners and it is a condition of accessing publications that users recognise and abide by the legal requirements associated with these

- Users may download and print one copy of any publication from the public portal for the purpose of private study or research.

- You may not further distribute the material or use it for any profit-making activity or commercial gain

If the publication is distributed under the terms of Article 25fa of the Dutch Copyright Act, indicated by the "Taverne" license above, 


\section{Atrophic gastritis during acid-suppressive therapy}

with focus on ECL cell hyperplasia

and intragastric bacteria 
Silvia Sănduleanu, Maastricht 2001

ISBN 9052783179

Cover design and printing: Datawyse / Universitaire Pers Maastricht

Scientific studies in this thesis were supported by AstraZeneca BV, The Netherlands. The financial support of AstraZeneca BV and Imphos/Medimphos Medical Supplies BV for the publication of this thesis is gratefully acknowledged. 


\title{
Atrophic gastritis during acid-suppressive therapy
}

\author{
with focus on ECL cell hyperplasia \\ and intragastric bacteria
}

\section{PROEFSCHRIFT}

ter verkrijging van de graad van doctor aan de Universiteit Maastricht, op gezag van de Rector Magnificus,

Prof. dr. A.C. Nieuwenhuijzen Kruseman, volgens het besluit van het College van Decanen, in het openbaar te verdedigen op vrijdag 28 september 2001 om 12.00 uur

door

Silvia Sănduleanu

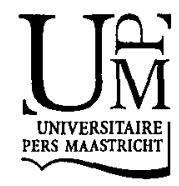


Promotor

Prof. dr. R.W. Stockbrügger

\section{Co-promotors}

Dr. W. Hameeteman

Dr. A. de Bruïne

Beoordelingscommissie

Prof. dr. C. Bruggeman (voorzitter)

Prof. dr. P. van den Brandt

Prof. dr. J.W. Cohen Tervaert

Prof. dr. E.J. Kuipers (Erasmus Universiteit Rotterdam)

Prof. dr. P. Sipponen (Jorvi Hospital, Espoo, Finland) 
Imagination is sometimes more important than knowledge... knowledge is limited but imagination recycles the world. When I examine myself and my methods of thought, I come close to the conclusion that the gift of imagination has meant more to me than the talent for absorbing absolute knowledge. 


\section{Abbreviations}

APAG

$A B G$

CPAG

CgA

ECL cell

$\mathrm{H}_{2} \mathrm{RA}$

PPI

H.pylori

non-H.pylori

IL

GORD antral predominant atrophic gastritis atrophic body gastritis corpus predominant atrophic gastritis chromogranin A enterochromaffin-like cell histamine ${ }_{2}$-receptor antagonist proton pump inhibitor Helicobacter pylori non-Helicobacter pylori interleukin gastro-oesophageal reflux disease 


\section{Contents}

Chapter 1 Introduction

Changes in gastric mucosa and luminal environment during acid-suppressive therapy:

a review in depth

Chapter 2 Aims and outline of the thesis

Chapter 3 Serum gastrin and chromogranin A during medium- and long-term acid suppressive therapy: a case-control study

Chapter 4 Serum chromogranin A as a screening test for gastric enterochromaffin-like cell hyperplasia during acid-suppressive therapy

Chapter 5 Non-Helicobacter pylori bacterial flora during acid-suppresive therapy: differential findings in gastric juice and gastric mucosa

Chapter 6 Double infection of the stomach with Helicobacter pylori and non-Helicobacter pylori bacteria: increase of pro-inflammatory cytokines and development of atrophic gastritis

Chapter 7 Prediction of atrophic body gastritis by serum markers

Chapter 8 General discussion

Chapter 9 Summary and concluding remarks

Chapter 10 Samenvatting en conclusies

Addendum

Acknowledgements

Publications 


\section{Chapter 1}

\section{Introduction \\ Changes in gastric mucosa and luminal environment during acid- suppressive therapy: a review in depth}

S Sanduleanu, D Jonkers, A de Bruïne, W Hameeteman, RW Stockbrügger 


\section{Introduction}

The gastrointestinal effects of acid-suppressive therapy rank highly amongst the investigated issues in gastroenterology over the past two to three decades. Early in that period debates have focused on: (i) intragastric bacterial overgrowth and its possible consequences, such as enteric infections, alterations in nutrient absorption, and formation of potentially carcinogenic $N$-nitroso compounds (NOCs); (ii) hypergastrinaemia and the proliferation of gastric enterochromaffin-like (ECL) cells.

It is only within the last few years that substantial interest has been devoted to the relationship between gastric acid secretion and gastric infection with Helicobacter pylori (H.pylori): the $\mathrm{pH}-\mathrm{Hp}$ interaction has inspired many studies, unraveling aspects of importance for both clinical practice and research. Herewith, we present an overview of the gastrointestinal effects of acid-suppressive therapy, with special attention to the impact of concurrent H.pylori infection on changes in gastric mucosa and luminal environment in this context.

\section{Gastrin and enterochromaffin-like cell proliferation}

The stomach comprises two regions with distinct anatomical and physiological conditions. The proximal two thirds of the stomach, known as the body and fundic region, contains acid-secreting parietal cells and histamine-releasing enterochromaffin-like (ECL) cells. The distal third of the stomach, known as the antral region, contains gastrin-producing $G$ cells and somatostatin-producing D cells ${ }^{1-3}$.

Intragastric acidity regulates the gastrin release from the antral $G$ cells through a negative feedback mechanism: when the gastric juice $\mathrm{pH}$ falls due to high parietal cell secretion, the release of gastrin is inhibited, whilst when the gastric juice $\mathrm{pH}$ rises, hypergastrinaemia ensues to stimulate the parietal cell mass. Gastrin also exerts a powerful trophic effect on the ECL cells ${ }^{4-6}$. This explains why rats with marked hypergastrinaemia, as a consequence of profound acid suppression with proton pump inhibitors (PPIs) or with histamine $2^{-}$ receptor antagonists $\left(\mathrm{H}_{2} \mathrm{RAs}\right)$, may develop ECL cell hyperplasia and even ECL cell carcinoids ${ }^{7-11}$. Similar changes in ECL cells have been documented in various other conditions associated with marked hypergastrinaemia, such as in rats subjected to partial fundectomy ${ }^{12}$ or after exogenous infusion of gastrin ${ }^{13}$. On the opposite, the administration of the gastrin receptor antagonist PD 136450 prevented ECL cell hyperplasia ${ }^{14}$. 
In humans, serum gastrin levels may increase up to four-fold in patients treated with omeprazole ${ }^{15,16}$; this is accompanied by development of diffuse, linear, and/or micronodular ECL cell hyperplasia ${ }^{17-21}$. Furthermore, gastric ECL cell carcinoids can develop in severely hypergastrinaemic patients, in connection with disorders such as type A chronic atrophic gastritis or the Zollinger-Ellison syndrome associated to multiple endocrine neoplasia (MEN) type $1^{22-27}$. Taken together, these observations have raised concern that long-term profound acid suppression in humans may promote gastric endocrine tumour growth ${ }^{28-30}$.

Solcia et al. ${ }^{31}$ addressed this issue in a study of 448 patients with acid-related disease, who were treated with omeprazole for periods up to four years. They reported an increase in the prevalence of micronodular ECL cell hyperplasia from $2.5 \%$ at baseline to $10.4 \%$ at final biopsy; however, no ECL cell dysplasia or ECL cell neoplasia were observed. Lamberts et al. ${ }^{18}$ studied - both quantitatively and qualitatively - the ECL cell changes in 74 patients with acid-related diseases, treated with omeprazole $20-80 \mathrm{mg}$ daily for up to five years. The ECL cell volume density increased from $0.36 \%$ of the total mucosa at baseline to $0.74 \%$ at 5 years; correspondingly, the percentage of patients with $\mathrm{ECL}$ cell hyperplasia increased from $36 \%$ at baseline to $67 \%$ at 5 years. Again, no ECL cell dysplasia or ECL cell neoplasia were observed.

Additional insights into the effects of acid-suppressive therapy on serum gastrin and gastric ECL cells have been gained after the discovery of H.pylori. In the presence of H.pylori infection, acid suppression results in a more marked gastrin elevation ${ }^{32-34}$ and a higher risk of developing $\mathrm{ECL}$ cell hyperplasia than in the non-infected subjects $^{35-39}$. Eissele et al. $^{37}$ investigated 42 patients with reflux oesophagitis or peptic ulcer disease, who were treated with lansoprazole for periods up to five years. They found an increase in the prevalence of linear/micronodular ECL cell hyperplasia from $6.7 \%$ to $54.5 \%$ in H.pylori-positive subjects, compared to an increase from $0 \%$ to $7.7 \%$ in the H.pylori-negative subjects. The longest follow-up period has been reported in a study by Klinkenberg-Knol et al. ${ }^{38}$ on 230 reflux oesophagitis patients, who were treated with omeprazole for a mean duration of 6.5 years (up to 11 years). The proportion of micronodular hyperplasia increased from $3 \%$ to $29 \%$ in the H.pylori-positive patients, compared to an increase from $3 \%$ to $11 \%$ in the H.pylori-negative group. Importantly, no premalignant or malignant ECL cell lesions were observed.

It can be concluded that available evidence now reassures the general safety of long-term (10 to 15 years) treatment with potent acid inhibitors in humans ${ }^{40-42}$. However, the consequences of 'life-long' iatrogenic hypergastrinaemia on the ECL cells in humans are presently 
not known, favouring caution in this respect ${ }^{43,44}$. The recent report ${ }^{45}$ of a patient who developed a gastric carcinoid tumour during long-term acidsuppressive therapy supports this attitude.

\section{Non-H.pylori bacterial growth during acid-suppressive therapy}

Most bacterial species do not survive at $\mathrm{pH}$ levels below 4; hence, the acidic gastric environment is considered the most important barrier against colonisation and infection by ingested bacteria ${ }^{46-49}$. It is wellestablished that low acid states resulting from pernicious anaemia ${ }^{50-52}$, partial gastrectomy ${ }^{53-55}$, truncal vagotomy ${ }^{56}$, or gastric cancer ${ }^{57-60}$, all predispose to colonisation of the stomach by aerobic and - to a minor degree - by anaerobic, gram-positive and gram-negative bacteria. Pooled data from studies in individuals with natural or artificial hypochlorhydria have documented a logarithmic relationship between intragastric $\mathrm{pH}$ and median bacterial counts ${ }^{61}$. Additionally, these studies have brought into focus potential consequences of the intragastric bacterial overgrowth, such as: (i) increased susceptibility for enteric infections; (ii) alterations in nutrient absorption; and (iii) formation of potentially carcinogenic $\mathrm{N}$-nitroso compounds.

\section{Enteric infections}

Intragastric hypochlorhydria increases the risk of enteric infections with bacterial agents (e.g. V.cholerae, species of Shigella and Salmonella or Clostridium difficile), or with parasitic agents (e.g. giardiasis, strongyloidiasis, amoebiasis) ${ }^{62-64}$. In a large population-based study, subjects taking acid-suppressive medication had a three-fold higher risk of developing bacterial diarrhoea than those taking antihypertensive or antiasthmatic medication. This effect was related to the degree of gastric acid inhibition (RR, omeprazole: 5.0; ranitidine: 3.7; cimetidine: $1.8)^{65}$. In a case-control study, treatment with acid inhibitors in the previous month was associated with an increased risk for Salmonellainfections (RR, 4.6), and Campylobacter-infections (RR, 11.7); such increased susceptibility was confined to the elderly subjects ${ }^{66,67}$.

\section{Altered nutrient absorption}

Much scientific effort has also been directed to the interrelation between bacterial overgrowth and alterations in the metabolisms of nutrients, minerals, and vitamins during natural and artificial hypochlorhydria and achlorhydria ${ }^{68-72}$.

In a series of seventeen healthy, elderly subjects with confirmed bacterial overgrowth - either due to atrophic gastritis or to omeprazole treatment (40 mg daily, 10 days), the $72-\mathrm{h}$ faecal fat levels - the index for fat malabsorption - were within the normal range ${ }^{73}$. 
Short-term treatment with omeprazole was also without significant effects on the absorption of dietary calcium, phosphorus, magnesium, or zinc in a study involving healthy volunteers ${ }^{74}$. Serum iron and ferritin concentrations have been monitored in 34 patients with peptic ulcer disease receiving omeprazole therapy up to four years; no significant decrease in their concentrations was found ${ }^{75}$.

However, current data suggest that acid suppression may impair the absorption of protein-bound vitamin $B_{12}$ (cobalamin) ${ }^{76-80}$. In a study of 34 patients receiving long-term omeprazole therapy, serum vitamin $B_{12}$ levels remained stable and within the normal range during the first three-year of follow-up; interestingly, a longer duration of acid-inhibitory treatment resulted in a slight but significant downward trend in serum vitamin $\mathrm{B}_{12}$ levels, although this was not confirmed by other investigators $^{75,77,81}$.

\section{$N$-nitrosamine formation}

An additional issue regarding the intragastric bacterial growth was related to the ability of some species to convert ingested nitrates to nitrites and $N$-nitrosamines ${ }^{82-84}$. In fact, formation of NOC may occur spontaneously in the acidic stomach (chemical nitrosation), or at neutral $\mathrm{pH}$ (bacterial nitrosation) ${ }^{85,86}$. The NOCs are mutagenic and carcinogenic in experimental animal models and have been suggested to play a role in the gastric carcinogenesis in humans ${ }^{87-90}$. Hence, these observations have prompted investigations to determine whether the intragastric bacterial growth during antisecretory therapy enhances the production of NOCs, and may thereby increase the risk of gastric cancer. Studies have been conducted in healthy volunteers and in patients with different acid-related conditions, thusfar, with conflicting results.

Stockbrügger et al. ${ }^{91}$ investigated 23 patients with peptic ulcer disease, who received a six-week course of cimetidine, $1 \mathrm{~g}$ daily. They reported a significant increase in intragastric aerobic and anaerobic bacteria and subsequently elevated gastric juice $N$-nitrosamines concentrations. Similar conclusions were drawn by Sharma et al. ${ }^{92}$ in a study of 10 healthy volunteers, who received a two-week course of omeprazole $30 \mathrm{mg}$ daily. On the contrary, Verdú et al. ${ }^{93}$, in a study of 14 healthy volunteers receiving a two-week course of omeprazole $20 \mathrm{mg}$ daily, reported increased bacterial concentrations (compared to a placebo-group), but no differences in nitrates, nitrites, or $N$-nitrosamines concentrations. Also, Thorens et al $^{94}$ investigated 47 patients with peptic ulcer disease, who received a four-week course of either omeprazole $20 \mathrm{mg}$ daily, or cimetidine $800 \mathrm{mg}$ daily. Increased intragastric bacterial counts were found, but no changes in the concentrations of nitrates, nitrites, and $\mathrm{N}$-nitrosamines. 
Several explanations could account for the dichotomy of results: First, it is known that the volatility of many NOCs makes it difficult to accurately quantify them; it can be reasoned that methodological aspects, such as differences in sample collection, storage, and analysis, could bring about different results. A second explanation could reside in differences in the degree of acid suppression achieved with the various regimens, as well as in the proportion of nitrate-reducing bacteria. Thirdly, recent data suggest that concurrent H.pylori infection may play a role in the intragastric $N$-nitrosation during acid suppression. As such, in H.pylori-negative subjects, short-term administration of either $\mathrm{H}_{2} \mathrm{RAs}$ or PPIs consistently increased the intragastric bacterial counts, but did not increase the gastric juice nitrates, nitrites, and $N$-nitroso compounds $^{95,96}$. On the opposite, in a study by Mowat et al., H.pyloripositive subjects treated with a PPI had greater elevation of intragastric $\mathrm{pH}$ and a 100 -fold greater degree of colonisation by non-H.pylori bacteria than the H.pylori-negative subjects. Additionally, the intragastric $\mathrm{N}$-nitrosamine formation was more marked in the H.pyloripositive treated subjects compared to the H.pylori-negatives ${ }^{97,98}$. At the first glance, the latter findings appear paradoxical, as H.pylori is known to have low nitrosation capacity ${ }^{99}$. It should be remembered, however, that chronic inflammation increases the production of nitric oxide (NO), which in turn can lead to nitrosation of amines ${ }^{100-102}$. Hence, it is tempting to hypothesize that the enhanced $N$-nitrosamine formation in $H$.pylori-infected subjects treated with acid suppression may result from nitrite production by the $H$.pylori-activated inflammatory cells, combined with nitrite production by the other (non-H.pylori) bacterial species.

\section{Helicobacter pylori gastritis and gastric acid secretion}

Helicobacter pylori infection elicits chronic-active inflammation of the gastric mucosa in nearly all colonised subjects ${ }^{103-106}$. Despite a vigorous immune response, the bacterium is not cleared spontaneously, and infection persists lifelong. The clinical outcome of the Helicobacterassociated disease is driven by an interplay between bacterial pathogenicity, host response, and environmental factors ${ }^{107,108}$.

McColl et al. have described a 'two-way interaction' between H.pylori gastritis and gastric acid secretion ${ }^{109,110}$. This is well-reflected during administration of acid-suppressive medication. It is known that H.pyloripositive subjects treated with acid suppression have higher intragastric $\mathrm{pH}$ than the H.pylori-negatives ${ }^{32-34,111-114}$. There are several reasons for this phenomenon: H.pylori infection causes body gastritis, which impairs parietal cell secretion ${ }^{114-116}$. Additionally, body gastritis is associated with loss of $M_{3}$ muscarinic receptors, further altering the gastric acid secretory function ${ }^{117}$. Also, H.pylori generates ammonia, with subsequent buffering of the intragastric acid ${ }^{118}$. Infection with H.pylori 
may stimulate the production of interleukin (IL)-1 $\beta$ and nitric oxide, which are recognised inhibitors of the gastric acid secretion ${ }^{119-121}$. In vitro, H.pylori releases acid-inhibitory substances, albeit their impact on the in vivo acid secretion remains unclear ${ }^{122-124 .}$

On the other hand, gastric acid secretion modulates the ecology and density of gastric colonisation by H.pylori, influencing the topographic subtype, extent, and severity of gastritis ${ }^{125-128}$. In hypersecretors, H.pylori colonisation and the subsequent chronic inflammation predominate in the antrum; these subjects are at risk of developing duodenal ulcer disease. In contrast, the hyposecretors are characterised by a body predominant pattern of gastritis, which results in impaired parietal cell function; the progression of inflammation causes destruction of the oxyntic glands, further compromising the gastric acid output, and eventually leading to chronic hypochlorhydria, and an increased risk of non-cardia gastric cancer.

\section{Classification of chronic gastritis}

Several classifications have been used to describe chronic gastritis ${ }^{129-}$ 138. In 1973, Strickland \& Mackay have proposed a topographic classification into three categories: the A-type (corpus alone), B-type (antrum alone), and $A B$-type (both antrum and corpus) ${ }^{129}$. The classification by Correa ${ }^{130}$ has suggested the division in diffuse antralpredominant gastritis and multifocal atrophic gastritis, which was later subdivided into non-ulcer pangastritis and progressive intestinalised metaplasia $^{138}$. As a strength, these classifications correlated the topography of chronic gastritis to the distinct functional consequences (e.g. the aforementioned effects on gastric acid secretion), and hence, to the expected clinical outcome. As a pitfall, they did not score atrophy and inflammation as distinct parameters, nor did they grade the severity of these items.

In the era of H.pylori, tighter guidelines for the diagnosis of chronic gastritis have been defined. The Sydney classification for the histological assessment of chronic gastritis - up-dated in 1994 - is presently used as the standard in clinical practice and research ${ }^{134-137}$. This classification is also subject of ongoing debates, mainly related to dissent on definition of gastric gland atrophy and inter-observer variations in the assessment of histopathological features of chronic gastritis $^{139,140}$. At the recent Atrophy 2000 Meeting, the definition of atrophy was clarified as 'absence of appropriate glands' (e.g. mucus glands in the gastric antrum and oxyntic glands in the gastric body ${ }^{141}$. The following major aspects have been emphasized: (i) gastric glands must be unequivocally 'absent', as opposed to 'displaced' and 'invisible only' because of concomitant infiltration of the lamina propria with inflammatory cells; in this latter situation, the term 'indefinite for atrophy' 
can be used as a temporary category, until the follow-up allows final judgement; (ii) any replacement of the normal glands by 'fibrosis and/or metaplastic epithelium' is equivalent to atrophy. Finally, it was agreed that the accurate diagnosis of gastric gland atrophy requires examination of multiple specimens, taken from both the antrum and the body mucosa. For research purposes, a single pathologist should review the histological material, in a blinded fashion, in order to minimize inter-observer bias.

\section{H.pylori gastritis and acid-suppressive therapy}

H.pylori gastritis usually predominates in the antrum and decreases gradually over the antral-body transitional zone ${ }^{142}$. This pattern of colonisation is due to the optimal $\mathrm{pH}$ that enables bacterial survival and growth. H.pylori is a neutralophil organism, with a recognised acid tolerance; this is attributable to the activity of urease enzyme, which is driven by a complex gene cluster ${ }^{143-147}$. In vitro, in the presence of urea, the optimal growth of H.pylori occurs at a $\mathrm{pH}$ level between 4.5 and $6^{143,144}$. Under physiological conditions, H.pylori colonisation predominates in the antrum. Treatment with acid-suppressive medication elevates the antral $\mathrm{pH}$, impairing the local growth conditions for H.pylori. As a consequence, a bacterial 'shift' occurs from the antrum to the body mucosa, with inversion in the gastritis pattern (from antral predominant gastritis to body predominant gastritis), and subsequent progression to body gland atrophy ${ }^{35,148-151}$. This observation originates, in fact, from older studies in patients with low-acid states, like gastric ulcer disease or following surgical vagotomy; in such cases an accelerated progression to atrophic gastritis - at an annual rate of $4-8 \%$ - has been observed ${ }^{152-154}$. This was in contrast to the 1-3\% annual rates of progression to atrophic gastritis reported in general populations ${ }^{155-158}$. A similar development was then noticed in patients treated with different types of antisecretory drugs, including $\mathrm{H}_{2} \mathrm{RAs}$ and antacids $^{159,160}$; however, this phenomenon has been thoroughly studied only after the introduction of profound inhibitors of gastric acid secretion, namely the PPIs ${ }^{10,19,20,31,35-39,161-168}$. Evidence now suggests that this phenomenon occurs within a few weeks to months after the start of treatment $^{169}$, and is reversible after the recovery of acid secretion ${ }^{149,170}$. As atrophic body gastritis is a recognised precursor lesion for the noncardia gastric cancer, concern and speculation have emerged regarding the potential risk for development of gastric cancer in this setting ${ }^{171,172}$.

Table 1.1 presents a chronological chart of the clinical studies investigating the gastric mucosal histology during treatment with different antisecretory drugs. Solcia et al. ${ }^{31}$ observed the development of atrophic gastritis in $12 \%$ out of 202 patients with reflux disease, who were treated with omeprazole for a mean period of 1.5 years. 


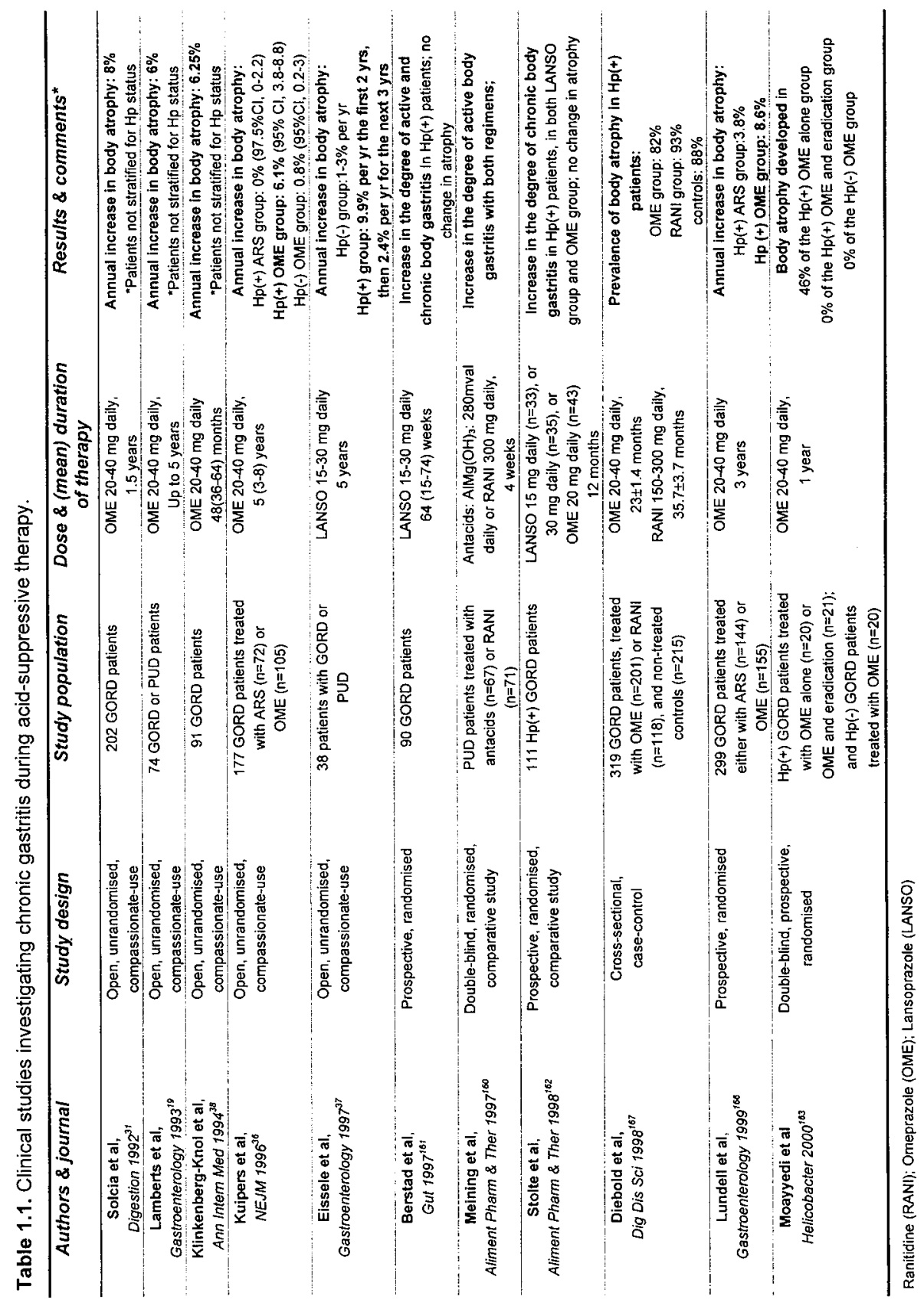


These changes were paralleled by an increase in the prevalence of micronodular ECL cell hyperplasia. In a study by Lamberts et al. ${ }^{19}, 19 \%$ out of 74 patients with either reflux diseases or peptic ulcer disease, treated with omeprazole for periods up to five years developed atrophy of the body mucosa.

In this context, the scientific interest shifted from the less harmful gastric ECL cell lesions towards the yet incompletely characterised behaviour of chronic gastritis during treatment with acid-suppressive medication. It became clear that further studies on this topic had to stratify for the H.pylori status of the subjects, and to use proper control populations as reference. In this sense, the study by Kuipers et al. ${ }^{36}$ offered major insights into this field. The authors have followed-up two GORD cohorts: one ( $n=105$ patients) was treated with omeprazole, and the other ( $n=72$ patients) was treated with fundoplication. In H.pylorinegative patients, the annual rate of progression to atrophic gastritis was less than $2 \%$ in both cohorts. The logical interpretation was that the development of gland atrophy per se cannot be attributed to the longterm treatment with PPIs alone. Similarly, in H.pylori-positive patients treated with fundoplication, nearly no atrophy developed during the follow-up. In contrast, in H.pylori-positive patients treated with omeprazole the body gastritis exacerbated gradually, and after five years of treatment one-third of these patients ended-up with body mucosal atrophy. The annual incidence of atrophic gastritis was $6.1 \%$ in this latter subgroup, significantly higher than in the H.pylori-positive subjects treated with fundoplication. It should be mentioned, however, that intestinal metaplasia developed in a minority of these cases only, and that it was almost exclusively of type I. Three other cohort studies in patients treated with lansoprazole confirmed the aggravation of body gastritis during acid inhibition ${ }^{37,161,162}$. Among them, the study by Berstad et al. ${ }^{161}$ reported increased epithelial cell proliferation in the body mucosa of H.pylori-positive patients treated with lansoprazole, paralleled by an increasing degree of chronic-active inflammation. However, some other studies did not support this hypothesis ${ }^{166-168}$. The most important evidence in this sense comes from a study by Lundell et al. ${ }^{166}$, in which body mucosal atrophy developed in $17.9 \%$ out of 39 H.pylori-positive GORD patients treated with omeprazole, compared to $4.5 \%$ out of $44 \mathrm{H}$.pylori-positive GORD patients treated with surgical fundoplication. As this difference did not achieve statistical significance, they claimed a 'lack of progression to atrophic gastritis in H.pyloripositive patients on omeprazole'. This conclusion triggered heated debates in the medical press, and criticism pointed towards a possible type 2 error of Lundell's study ${ }^{173-177}$. Additionally, the pre-treatment and/or post-treatment with omeprazole or vagotomy of patients in the 
antireflux surgery arm could have biased the results and the conclusion of this study.

It can be concluded that the aggravation of body gastritis in H.pyloripositive patients treated with acid suppression is a consistent observation in most of the available studies. This favours the present concept that 'H.pylori test-and treat strategy' is advisable prior to the start of long-term acid-suppressive therapy in order to prevent the accelerated development of atrophic gastritis in this setting ${ }^{163,178}$.

\section{Atrophic gastritis during acid-suppressive therapy: pathophysiological aspects}

Since the recognition of gastric atrophy in 1870 - in postmortem samples from a patient with pernicious anaemia ${ }^{179}$ - much attention and research interest have been devoted to decipher its underlying pathophysiology. There is presently no doubt that infection with H.pylori is a major cause of chronic atrophic gastritis. The more virulent cagApositive H.pylori bacterial strains induce a more severe gastritis and a more rapid progression to glandular loss than the cagA-negative strains ${ }^{180-183}$. Importantly, recent evidence highlights the critical role of host genetic factors, such as abnormal variants of IL-1 $\beta$ gene, in the development of atrophic gastritis and gastric cancer in H.pylori-positive individuals ${ }^{184}$. The contribution of the environmental factors (e.g. salt, micronutrients and vitamins intake, alcohol consumption, and smoking) to this development, although long-recognised, remains heretofore illdefined ${ }^{130,185-187}$. Among these environmental factors, treatment with acid-suppressive medication is known to induce complex changes in the intragastric environment, which encompass both the luminal and the mucosal compartment. Their characterisation is of great importance, as it may provide the rationale for the observed rapid development of atrophic gastritis in this context.

It has been shown that H.pylori colonisation density of the body mucosa does not change significantly during acid suppression ${ }^{35,163}$. This suggests that the aggravation of chronic body gastritis may depend on H.pylori infection as well as on additional, yet unknown factors. 


\section{Which effects has gastric acid suppression on the intragastric milieu in the presence of $H$.pylori infection?}

- Decreased gastric acid secretion favours a deeper location of H.pylori in the mucosal foveolae; it also hampers the dilution and washout of the cytotoxic and pro-inflammatory agents induced by H.pylori infection, which in turn may cause mucosal damage ${ }^{37,188-192}$. Under normal acidic conditions, the ammonia produced by H.pylori is ionized, being unable to penetrate through the epithelial cells, whilst at high intragastric $\mathrm{pH}$, ammonia remains unionized and may exert toxic effects. Additionally, chemical alterations of bacterial toxins in a less acidic environment could aggravate mucosal damage ${ }^{163,189}$.

- H.pylori-positive subjects treated with acid suppression have greater increases of intragastric $\mathrm{pH}$ than the H.pylori-negative subjects. This chronic gastric hypochlorhydria predisposes to colonisation by nonH.pylori bacterial species, and subsequently increased nitrite concentrations, and decreased vitamin $C$ in the gastric juice may occur $^{98}$. Additionally, intragastric bacteria may produce alcoholdehydrogenase, which in turn promotes the synthesis of acetaldehyde from alcohol ${ }^{193,194}$. All these biochemical alterations are deemed to have mutagenic and carcinogenic effects.

- Antigenic mimicry has been described between H.pylori and gastric mucosa, and such autoimmune phenomena may result in development of body atrophic gastritis ${ }^{195-198}$. By analogy with pernicious anaemia, it is tempting to speculate that chronic hypochlorhydria may enhance and perpetuate these changes, through yet unknown mechanisms.

- H.pylori-positive subjects treated with acid suppression also have elevated gastrin levels, which are $30-50 \%$ greater than in H.pylorinegative subjects. The magnitude of the hypergastrinaemic response is also driven by host factors, such as CYP2C19 polymorphism ${ }^{199}$. Recent experimental data suggested that hypergastrinaemia, in itself, may contribute to the development of gastric gland atrophy ${ }^{200}$. Transgenic mice with moderate hypergastrinaemia showed progression to atrophic gastritis and gastric cancer, probably through activation of several growth factors. Furthermore, the concurrent infection with H.pylori accelerated this process. 


\section{Gastric mucosa and luminal environment during acid-suppressive therapy:}

\section{What do we know on this topic?}

- During long-term acid suppression, gastric fundic ECL cell hyperplasia may develop, especially in the presence of H.pylori infection. So far, in humans, no neoplastic changes directly attributable to pharmacological acid inhibition have been demonstrated.

- Acid-suppressive therapy increases the risk of enteric infections.

- Acid-suppressive therapy does not alter fat and mineral bioavailability, but it may decrease the absorption of proteinbound vitamin $B_{12}$.

- Acid suppression invariably results in overgrowth of nonH.pylori bacteria; the concurrent infection with H.pylori may facilitate intragastric formation of $\mathrm{N}$-nitrosamines.

- The clinical outcome of H.pylori gastritis is strongly influenced by the individual gastric acid secretory status: in hypersecretors, gastritis predominates in the antrum, and may lead to duodenal ulcer disease; in hyposecretors, gastritis predominates in the body mucosa, and may lead to gland atrophy, chronic hypochlorhydria, and risk of gastric cancer.

- Acid-suppressive therapy alters the H.pylori gastritis, transforming the antral-predominant pattern into a bodypredominant pattern. This phenomenon may occur during treatment with any type of antisecretory drug.

- The aggravation of chronic body gastritis during acid suppression is confined to the H.pylori-positive subjects. So far, the underlying pathophysiology remains unclear.

- Eradication of H.pylori prior to the start of acid-suppressive therapy may prevent the aggravation of chronic body gastritis in this setting. 


\section{References}

1. Bordi C, Ravazzola M, deVita O. Pathology of endocrine cells in gastric mucosa. Ann Pathol 1983;3:19-28.

2. D'Adda T, Bordi C. Ultrastructure of a neuroendocrine complex in oxyntic mucosa of normal stomach. Cell Tissue Res 1988;254:465-7.

3. Bordi C, D'Adda T, Baggi MT, Pilato FP. Structure and function of endocrine cells in the oxyntic (acid-secreting) mucosa of human stomach. Scand J Gastroenterol 1989;24(S 166):115.

4. Håkanson R, Böttcher $G$, Sundler F, Vallgren S. Activation and hyperplasia of gastrin and enterochromaffin-like cells in the stomach. Digestion 1986;35(S 1):4255.

5. Creutzfeldt $W$. The achlorhydria-carcinoid sequence. Role of Gastrin. Digestion 1988;39:61-79.

6. Håkanson R, Sundler F. Proposed mechanism of induction of gastric carcinoids. The gastrin hypothesis. Eur J Clin Invest 1990;20(S 1):65-71.

7. Poynter D, Pick CR, Harcourt RA, Selway SA, Harman IW, Spurling NW, Flucks $P A$, Cook JL. Association of long lasting unsurmontable histamine $\mathrm{H}_{2}$ blockade and gastric carcinoid tumours in the rat. Gut 1985;26:1284-95.

8. Larsson H, Carlsson E, Mattsson H, Lundell L, Sundler F, Sundell G, et al. Plasma gastrin and gastric enterochromaffin-like cell activation and proliferation. Studies with omeprazole and ranitidine in intact and antrectomized rats. Gastroenterology 1986;90:391-9.

9. Tielemans $Y$, Håkanson R, Sundler F, Willems G. Proliferation of enterochromaffinlike cells in omeprazole treated hypergastrinemic rats. Gastroenterology 1989;96:723-9.

10. Havu N, Mattson H, Ekman L, Carlsson E. Enterochromaffin-like cell carcinoids in the rat gastric mucosa following long-term administration of ranitidine. Digestion 1990;45:189-195.

11. Eissele R, Rosskopf B, Koop H, Adler G, Arnold R. Proliferation of endocrine cells in the rat stomach caused by drug-induced achlorhydria. Gastroenterology 1991;101:70-6.

12. Mattsson H, Havu N, Bräutigam J, Carlsson K, Lundell L, Carlsson E. Partial gastric corpectomy results in hypergastrinemia and development of gastric enterochromaffin-like carcinoids in the rat. Gastroenterology 1991;100:311-9.

13. Ryberg B, Axelson J, Håkanson R, Sundler $F$, Mattson $H$. Trophic effects of continuous infusion of $\left(\right.$ Leu $\left.^{15}\right)$-gastrin-17 in the rat. Gastroenterology 1990; 98:338.

14. Eissele R, Parberg H, Koop H, Krack W, Lorenz W, McKnight AT, et al. Effect of gastrin receptor blockade on endocrine cells in rats during achlorhydria. Gastroenterology 1992;103:1596-601.

15. Koop $\mathrm{H}$, Klien $M$, Arnold $\mathrm{R}$. Serum gastrin levels during long-term omeprazole treatment. Aliment Pharmacol Ther 1990;4(2):131-8.

16. Banjaree S, Ardill JES, Beattie AD, McColl KEL. Effect of omeprazole and feeding on plasma gastrin in patients with achlorhydria. Aliment Pharmacol Ther 1995;9:507-12.

17. Solcia E, Rindi G, Havu N, Elm G. Qualitative studies of gastric endocrine cells in patients treated long-term with omeprazole. Scand J Gastroenterol 1989;24(S 166):129-37.

18. Brunner G, Creutzfeldt W, Harke U, Lamberts R. Efficacy and safety of long-term treatment with omeprazole in patients with acid-related diseases resistant to ranitidine. Can J Gastroenterol 1989;3(S A):72-6. 
19. D'Adda T, Pilato FP, Lazzaroni M, Robutti F, Bianchi-Porro G, Bordi C. Ultrastructural morphometry and gastric endocrine cells before and after omeprazole. Gastroenterology 1991;100:1563-70.

20. Lamberts L, Creutzfeldt W, Strüber HG, Brunner G, Solcia E. Long-term omeprazole therapy in peptic ulcer disease: gastrin, endocrine cell growth, and gastritis. Gastroenterology 1993;104:1356-70.

21. Klinkenberg-Knol EC, Festen HPM, Jansen JBMJ, Lamers CBHW, Nelis F, Snel P, et al. Long-term treatment with omeprazole for refractory reflux esophagitis: efficacy and safety. Ann Intern Med 1994;121:161-7.

22. Bordi C, Pilato F, Carfagna G, Ferrari C, D'Adda T, Sivelli R, et al. Argyrophil cell hyperplasia of fundic mucosa in patients with chronic atrophic gastritis. Digestion 1986; 35 (Suppl 1):130-43.

23. Borch K, Renvall H, Liedberg G. Gastric endocrine cell hyperplasia and carcinoid tumors in pernicious anemia. Gastroenterology 1985;88:638-48.

24. Solcia E, Fiocca R, Villani L, Gianatti A, Cornaggia M, Chiaravalli A, et al. Morphology and natural history of endocrine hyperplasias, precarcinoid lesions, and carcinoids arising in chronic atrophic gastritis. Gastroenterology 1991;26(S 180):146-59.

25. Lehy $T$, Mignon $M$, Cadiot G, Elouaer-Blanc L, Ruszniewski P, Lewin MJ, et al. Gastric endocrine cell behaviour in Zollinger-Ellison patients upon long-term potent antisecretory treatment. Gastroenterology 1989;96:1029-40.

26. Solcia E, Capella C, Fiocca R, Rindi G, Rosai J. Gastric argyrophil carcinoidosis in patients with Zollinger-Ellison syndrome due to type 1 multiple endocrine neoplasia. A newly recognized association. Am J Surg Pathol 1990;14:503-13.

27. Lehy $T$, Cadiot $G$, Mignon M, Ruszniewski $P$, Bonfils S. Influence of multiple endocrine neoplasia type-1 on gastric endocrine cells in patients with the ZollingerEllison syndrome. Gut 1992;33:1275-9.

28. Creutzfeldt W, Lamberts R. Is hypergastrinaemia dangerous to man? Scand J Gastroenterol 1991;26(S 180):179-91.

29. Freston JW. Clinical significance of hypergastrinaemia: relevance to gastrin monitoring during omeprazole therapy. Digestion 1992;51(S 1):102-14.

30. Waldum HL, Brenna E, Kleveland PM, Sandvik AK. Gastrin-Physiological and Pathophysiological Role: Clinical Consequences. Dig Dis 1995;13:25-38.

31. Solcia E, Fiocca R, Havu N, Dalväg A, Carlsson R. Gastric endocrine cells and gastritis in patients receiving long-term omeprazole treatment. Digestion 1992;51(S 1):82-92.

32. Katelaris PH, Seow F, Lin BPC, Napoli J, Ngu MC, Jones DB. Effect of age, Helicobacter pylori infection, and gastritis with atrophy on serum gastrin and gastric acid secretion in healthy men. Gut 1993;34:1032-7.

33. Mossi S, Meyer-Wyss B, Renner EL, Merki HS, Gamboni G, Berlinger C. Influence of Helicobacter pylori, sex, and age on serum gastrin and pepsinogen concentrations in subjects without symptoms and patients with duodenal ulcers. Gut 1993;34:752-6.

34. El-Omar EM, Penman ID, Ardill JES, Chittajallu RS, Howie C, McColl KEL. Helicobacter pylori infection and abnormalities of acid secretion in patients with duodenal ulcer disease. Gastroenterology 1995;109:681-91.

35. Kuipers EJ, Uyterlinde AM, Peña AS, Hazenberg HJA, Bloemena E, Lindeman J, et al. Increase of Helicobacter pylori associated corpus gastritis during acid suppressive therapy: implications for long-term safety. Am J Gastroenterol 1995;90:1402-6.

36. Kuipers EJ, Lundell L, Klinkenberg-Knol, Havu N, Festen HP, Liedman B, et al. Atrophic gastritis and Helicobacter pylori infection in patients with reflux esophagitis treated with omeprazole or fundoplication. N Engl J Med 1996;334:1018-22. 
37. Eissele R, Brunner G, Simon B, Solcia E, Arnold R. Gastric mucosa during treatment with lansoprazole: Helicobacter pylori is a risk factor for argyrophil cell hyperplasia. Gastroenterology 1997;112:707-717.

38. Klinkenberg-Knol EC, Nelis F, Dent J, Snel P, Mitchell B, Prichard P, et al. Longterm omeprazole treatment in resistant gastroesophageal reflux disease: efficacy, safety, and influence on gastric mucosa. Gastroenterology 2000;118:661-9.

39. Solcia E, Villani L, Luinetti O, Fiocca R. Proton pump inhibitors, enterochromaffinlike cell growth and Helicobacter pylori gastritis. Aliment Pharmacol Ther 1993; 7(Suppl 1):25-28.

40. Garnett WR. Considerations for long-term use of proton-pump inhibitors. Am J Health-Syst Pharm 1998;55:2268-79.

41. Laine L, Ahnen D, McClain C, Solcia E, Walsh JH. Review article: potential gastroentestinal effects of long-term acid suppression with proton pump inhibitors. Aliment Pharmacol Ther 2000;14:651-68.

42. Proton Pump Inhibitor Relieving for Cancer Risk Not Warranted. F-D-C Reports 1996;58.

43. Waldum HL. Brenna E. Personal review: is profound acid inhibition safe? Aliment Pharmacol Ther 2000;14:15-22.

44. Yeomans ND, Dent J. Personal review: alarmism or legitimate concers about longterm suppression of gastric acid secretion? Aliment Pharmacol Ther 2000;14:26771.

45. Haga Y, Nakatsura T, Shibata $Y$, Sabeshima H, Nakamura $Y$, Tanimura, et al. Human gastric carcinoid detected during long-term anti-ulcer therapy of $\mathrm{H}_{2}$ receptor antagonist and proton pump inhibitor. Dig Dis Sci 1998;43:253-7.

46. Gray JD, Shiner M. Influence of gastric $\mathrm{pH}$ on gastric and jejunal flora. Gut 1967:8:574-81.

47. Drasar BS, Shiner M, McLeod GM. Studies on the intestinal flora. The bacterial flora of the gastrointestinal tract in healthy and achlorhydric persons. Gastroenterology 1969;56:71-9.

48. Gianella RA, Broitman SA, Zamcheck N. Gastric acid barrier to ingested microorganisms in man: studies in vivo and in vitro. Gut 1972;13:251-6.

49. Wilder-Smith $\mathrm{CH}$, Spirig $\mathrm{C}$, Krech $\mathrm{T}$, Merki HS. Bactericidal factors in gastric juice. Eur J Gastroenterol Hepatol 1992;4:885-91.

50. Stockbrügger RW, Cotton PB, Menon GG, Beilby JO, Bartholomew BA, Hill MJ, et al. Pernicious anaemia, intragastric bacterial overgrowth and possible consequences. Scand J Gastroenterol 1984;19:355-64.

51. Stockbrügger RW. Bacterial overgrowth as a consequence of reduced gastric acidity. Scand J Gastroenterol 1985;20(S 111):7-16.

52. Dolby JM, Webster ADB, Boriello SP, Barclay FE, Bartholomew BA, Hill MJ. Bacterial colonization and nitrite concentration in the achlorhydric stomachs of patients with primary hypogammaglobulinaemia or classical pernicious anaemia. Scand J Gastroenterol 1984;19:105-10.

53. Muscroft TJ, Deane SA, Younds D, Burdon DW, Keighley MRB. The microflora of the postoperative stomach. Br J Surg 1982;68:560-4.

54. Armbrecht U, Bosaeus I, Gilberts R, Seeberg S, Stockbrügger RW. Hydrogen $\left(\mathrm{H}_{2}\right)$ breath test and gastric bacteria in acid-secreting subjects and in achlorhydria and post-gastrectomy patients before and after antimicrobial treatment. Scand J Gastroenterol 1985;20:805-13.

55. Carboni M, Guadagni S, Pistoia MA, Amicucci G, Tuscano D, Negro P, et al. The microflora of the gastric juice after Billroth I and Billroth II partial gastrectomy. Scand J Gastroenterol 1986;21:461-70.

56. Meyrick-Thomas J, Misiewicz JJ, Cook AR, et al. Effects of one year's treatment with ranitidine and of truncal vagotomy on gastric contents. Gut 1987;28:726-38. 
57. Correa P, Cuello C, Duque E. Carcinoma and intestinal metaplasia of the stomach in Columbian migrants. J Natl Cancer Inst 1970;44:297-306.

58. Jonkers D, Gisbertz I, de Bruïne A, Bot F, Arends JW, Stobberingh E, et al. Helicobacter pylori and non-Helicobacter pylori bacterial flora in gastric mucosal and tumour specimens of patients with primary gastric lymphoma. Eur $\mathrm{J}$ Clin Invest 1997;27:885-92.

59. Jonkers D, Houben P, Hameeteman W, Stobberingh E, de Bruine A, Arends JW, et al. Differential features of gastric cancer patients, either Helicobacter pylori positive or Helicobacter pylori negative. Ital J Gastroenterol Hepatol 1999;31(9):836-41.

60. Houben GMP, Stockbrügger RW. Bacteria in the aetio-pathogenesis of gastric cancer: a review. Scand J Gastroenterol 1995;30(S 212):13-8.

61. Yeomans ND, Brimblecombe RW, Elder J, Heatley RV, Misiewicz JJ, Northfield $\mathrm{TC}$, et al. Effects of acid suppression on microbial flora of upper gut. Dig Dis Sci 1995;40(S 2):81-95.

62. Cook GC. Infective gastroenteritis and its relationship to reduced gastric acidity. Scand J Gastroenterol Hepatol 1985;20(S 111):17-21.

63. Howden $\mathrm{CW}$, Hunt $\mathrm{RH}$. The relationship between gastric secretion and infection. Gut 1987;28:3658-62.

64. Cook GC. Hypochlorhydria and vulnerability to intestinal infection. Eur J Gastroenterol Hepatol 1994;6:693-5.

65. Nwokolo $C$, Loft $D$, Holder $R$, Langman $M$. Increased incidence of bacterial diarrhoea in patients taking gastric acid antisecretory drugs. Eur J Gastroenterol Hepatol 1994;6:697-9.

66. Neal KR, Briji SO, Slack RC, Hawkey CJ, Logan RF. Recent treatment with $\mathrm{H}_{2}$ antagonists and antibiotics and gastric surgery as risk factors for salmonella infection. BMJ 1994;308:176.

67. Neal KR, Scott HM, Slack RC, Logan RF. Omeprazole as a risk factor for campylobacter gastroenteritis: case-control study. BMJ 1996;312:414-5.

68. Tabaqchali S, Booth CC. Relationship of the intestinal bacterial flora to absorption. Br Med Bull 1967;23(3):285-90.

69. Roberts $\mathrm{SH}$, James $\mathrm{O}$, Jarvis $\mathrm{EH}$. Bacterial overgrowth syndrome without "blind loops": a cause for malnutrition in the elderly. Lancet 1977;ii:1193-95.

70. Domellöf L, Reddy BS, Weisburger JH. Microflora and deconjugation of bile acids in alkaline reflux after partial gastrectomy. Am J Surg 1980;140:291-295.

71. Stockbrügger RW, Armbrecht U, Rode JW, Teall AJ, Oberholzer VG, Crocker JR, et al. The bacterial overgrowth syndrome is uncommon in pernicious anaemia. Microbial Ecol Health Dis 1990;3:209-215.

72. Walan A, Ström M. Metabolic consequences of reduced gastric acidity. Scand J Gastroenterol 1995;20(S 111):24-9.

73. Saltzman JR, Kowdley KV, Pedrosa MC, Sepe T, Golner B, Perrone G, et al. Bacterial overgrowth without clinical malabsorption in elderly hypochlorhydric subjects. Gastroenterology 1994;106:615-23.

74. Serfaty-Lacrosniere C, Wood RJ, Voytko D, Saltzman JR, Pedrosa M, Sepe T, et al. Hypochlorhydria from short-term omeprazole treatment does not inhibit intestinal absorption of calcium, phosphorus, magnesium or zinc from food in humans. J Am Coll Nutr 1995;14:364-8.

75. Koop $H$, Bachem MG. Serum iron, ferritin, and vitamin $B_{12}$ during prolonged omeprazole therapy. J Clin Gastroenterol 1992;14:288-92.

76. Steinberg WM, King CE, Toskes PP. Malabsorption of protein-bound cobalamin but not unbound cobalamin during cimetidine administration. Dig Dis Sci 1980;25:18891.

77. Marcuard SP, Albernaz L, Khazanie PG. Omeprazole therapy causes malabsorption of cyanocobalamin (vitamin $B_{12}$ ). Ann Intern Med 1994;120:211-5. 
78. Saltzman JR, Kemp JA, Golner BB, Pedrosa MC, Dallal GE, Russell RM. Effect of hypochlorhydria due to omeprazole treatment or atrophic gastritis on protein-bound vitamin $B_{12}$ absorption. J Am Coll Nutr 1994;13:584-91.

79. Schenk BE, Festen HPM, Kuipers EJ, Klinkenberg-Knol EC, Meuwissen SGM. Effect of short- and long-term tretment with omeprazole on the absorption and serum levels of cobalamin. Aliment Pharmacol Ther 1996;10:541-5.

80. Koop H. Review article: metabolic consequences of long-term inhibition of acid secretion by omeprazole. Aliment Pharmacol Ther 1992;6:399-466.

81. Schenk BE, Festen HP, Kuipers EJ, Klinkenberg-Knol E, Meuvissen SG. Effect of short- and long-term treatment with omeprazole on the absorption and serum levels of cobalamin. Aliment Pharmacol Ther 1996;10(4):541-5.

82. Suzuki K, Mitsuoka T. N-nitrosamine formation by intestinal bacteria. In: O'Neill I, von Borstel RC, Miller CT, Long J, Bartsch H, editors, 1984. $\mathrm{N}$-nitroso compounds: Occurrence, biological effects and relevance to human cancer. IARC Sci. Publ., International Agency for Research on Cancer, Lyon, No. 57, 275-81.

83. Massey RC, Key PE. An investigation of the endogenous formation of apparent total $\mathrm{N}$-nitroso compounds in conventional microflora and germ-free rats. Food Chem Toxic 1988;26:595-600.

84. Yeomans ND, Brimblecombe RW, Elder J, Heatley RN, Misiewicz JJ, Northfield $\mathrm{TC}$, et al. Effects of acid suppression on microbial flora of upper gut. Dig Dis Sci $1995 ; 40: 81$ S-95S.

85. Leach SA, Thompson M, Hill M. Bacterially catalysed $N$-nitrosation reactions and their relative importance in the human stomach. Carcinogenesis 1987;8:1907-12.

86. Xu GP, Reed PI. N-nitroso compounds in fresh gastric juice and their relation to intragastric $\mathrm{pH}$ and nitrite employing and improved analytical method. Carcinogenesis 1993;14:2547-51.

87. Mirvish SS. The etiology of gastric cancer: Intragastric nitrosamide formation and other theories. J Nath Cancer Inst 1983;71:631-47.

88. Forman D, Al Dabbagh S, Doll R. Nitrates, nitrites and gastric cancer in Great Britain. Nature 1985;313:620-5.

89. Magee PN. The experimental basis for the role of nitroso compounds in human cancer. Cancer Surv 1989;8:207-39.

90. Hill MJ. Mechanisms of gastric carcinogenesis. Eur J Clin Prev 1993;2:73-8.

91. Stockbrügger RW, Cotton PB, Eugenides N, Bartholomew BA, Hill MJ. Walters CL. Intragastric nitrites, nitrosamines, and bacterial overgrowth during cimetidine treatment. Gut 1982;23:1048-54.

92. Sharma BK, Santana IA, Wood EC, Walt RP, Pereira M, Noone P, et al. Intragastric bacterial activity and nitrosation during, and after treatment with omeprazole. BMJ 1984;289:717-9.

93. Verdú $E$, Viani $F$, Armstrong D, Fraser R, Siegrist $H H$, Pignatelli $B$, et al. Effect of omeprazole on intragastric bacterial counts, nitrates, nitrites, and $\mathrm{N}$-nitroso compounds. Gut 1994;35:455-60.

94. Thorens J, Froelich F, Schwizer W, Saraga E, Bille J, Gyr K, et al. Bacterial overgrowth during treatment with omeprazole compared with cimetidine: a prospective randomised double blind study. Gut 1996;39:54-9.

95. Houben GMP, Hooi J, Brummer R-JM, Stobberingh EE, Stockbrügger RW. Intragastric bacterial growth, nitrates, nitrites, and $N$-nitroso compounds after 300 $\mathrm{mg}$ ranitidine b.d., $20 \mathrm{mg}$ omeprazole, $40 \mathrm{mg}$ omeprazole and placebo. Eur $\mathrm{J}$ Cancer Prev 1996;5 (S 1):59-61.

96. Viani F, Siegrist HH, Pignatelli B, Cederberg C, Idström JP, Verdú EF, et al. The effect of intragastric acidity and flora on the concentration of $\mathrm{N}$-nitroso compounds in the stomach. Eur J Gastroenterol Hepatol 2000;12:165-73. 
97. Mowat C, Williams C, Gillen D, Hossack M, Gilmour D, Carswell A, et al. Omeprazole, Helicobacter pylori status, and alterations in the intragastric milieu facilitating bacterial $N$-nitrosation. Gastroenterology 2000;119:339-47.

98. Mowat C, Carswell A, Wirz A, McColl KEL. Omeprazole and Dietary Nitrate independently affect levels of vitamin $\mathrm{C}$ and nitrite in gastric juice. Gastroenterology $1999 ; 116: 813-22$.

99. Ziebarth D, Spiegelhalder B, Bartsch H. N-nitrosation of medicinal drugs catalysed by bacteria from human saliva and gastro-intestinal tract, including Helicobacter pylori. Carcinogenesis 1997;18:383-9.

100. Miwa M, Stuehr DJ, Marletta MA, Wishnok JS, Tannenbaum SR. Nitrosation of amines by stimulated macrophages. Carcinogenesis 1987;8:955-8.

101. Grisham MB, Ware K, Gilleland HE Jr, Gilleland LB, Abell CL, Yamada T. Neutrophil-mediated nitrosamine formation. Role of nitric oxide in rats. Gastroenterology 1992;103:1260-6.

102. Ohshima $\mathrm{H}$, Bartsch $\mathrm{H}$. Chronic infections and inflammatory processes as cancer risk factors: possible role of nitric oxide in carcinogenesis. Mutat Res 1994;305:253-64.

103. Marshall BJ, Armstrong JA, McGechie DB, Glanchy RJ. Attempt to fulfill Koch postulates for pyloric Campylobacter. Med J Austr 1985;142:436-9.

104. Morris A, Nicholson G. Ingestion of Campylobacter pyloridis causes gastritis and raised gastric juice $\mathrm{pH}$. Am J Gastroenterol 1987;82:192-9.

105. Rauws EAJ, Langenberg W, Houthoff HJ, Zanen HC, Tytgat GN. Campylobacter pyloridis-associated chronic active antral gastritis. A prospective study of its prevalence and the effects of antibacterial and anti-ulcer treatment. Gastroenterology 1988;94:33-40.

106. Dixon MF. Helicobacter pylori and peptic ulceration; histopathological aspects. J Gastroenterol Hepatol 1991;6:125-30.

107. Blaser MJ. Hypothesis on the pathogenesis and natural history of Helicobacter pylori-induced inflammation. Gastroenterology 1992;102:720-7.

108. Sipponen P, Kekki M, Siurala M. The relationships between chronic gastritis and gastric acid secretion. Aliment Pharmacol Ther 1996;10(Suppl 1):103-8.

109. McColl KEL, El-Omar E, Gillen D. Interactions between H.pylori infection, gastric acid secretion and anti-secretory therapy. Br Med Bull 1998;54(No. 1):121-38.

110. McColl KEL, El-Omar E, Gillen D. Helicobacter pylori gastritis and gastric physiology. Gastroenterol Clin North Am 2000;29 (3):687-703.

111. Verdú EF, Armstrong D, Fraser R, Viani F, Idström JP, Cederberg $C$, et al. Effect of Helicobacter pylori status on intragastric $\mathrm{pH}$ during treatment with omeprazole. Gut $1995 ; 36: 539-43$.

112. Labenz J, Tillenburg B, Peitz, Idström JP, Verdú EF, Stolte M, et al. Helicobacter pylori augments the $\mathrm{pH}$-increasing effect of omeprazole in patients with duodenal ulcer. Gastroenterology 1996;110:725-32.

113. Labenz J, Tillenburg B, Peitz U, Verdú EF, Stolte M, Borsch G, et al. Effect of curing Helicobacter pylori infection on intragastric acidity during treatment with ranitidine in patients with duodenal ulcer. Gut 1997;41:33-6.

114. El-Omar E, Oien K, El-Nujumi A, Gillen D, Wirz A, Dahill S, et al. Helicobacter pylori infection and chronic gastric acid hyposecretion. Gastroenterology 1997;113:15-24.

115. Feldman M, Cryer B, McArthur KE, Huet BA, Lee E. Effects of aging and gastritis on gastric acid and pepsin secretion in humans: A prospective study. Gastroenterology 996;110:1043-52.

116. Yasunaga $Y$, Shinomura $Y$, Kanayama $S$, Yaby $M$, Nakamishi $T$, Miyaxaki $Y$. Improved fold width and increase acid secretion after eradication of the organism in Helicobacter pylori associated enlarged fold gastritis. Gut 1994;35:1571-4. 
117. Pfeiffer A, Kromer W, Friemann J, Ruge M, Herawi M, Schatze M, et al. Muscarinic receptors in gastric mucosa are increased in peptic ulcer disease. Gut 1995;36:813-8.

118. Levi S, Beardshall K, Haddad G, Playford R, Ghosh P, Calam J. Campylobacter pylori and duodenal ulcers: the gastrin link. Lancet 1989;i:1167-8.

119. Noach LA, Bosma NB, Jansen JB, Hoek FJ, van Deventer S.JH, Tytgat G. Mucosal tumor necrosis factor- $\alpha$, interleukin- $1 \beta$, and interleukin- 8 production in patients with Helicobacter pylori infection. Scand J Gastroenterol 1994;29:425-9.

120. Wallace JL, Cucala M, Mugridge K, Parente L. Secretagogue-specific effects interleukin-1 on gastric acid secretion. Am J Physiol 1991;261:G559-G64.

121. Wilson KT, Ramanujam KS, Mobley HLT, Musselman RF, James SP, Meltzer SJ. Helicobacter pylori stimulates inducible nitric oxide synthase expression and activity in a murine macrophage cell line. Gastroenterology 1996;111:1524-33.

122. Cave DR, Vargas M. Effect of a Campylobacter pylori protein on acid secretion by parietal cells. Lancet 1989;ii:187-9.

123. Cave DR, King WW, Hoffman JS. Production of two chemically distinct acidinhibitory factors by Helicobacter pylori. Eur J Gastroenterol Hepatol 1993;5 (S 1):23-2.

124. Beil W, Birkholz C, Wagner S, Sewing K-F. Interaction of Helicobacter pylori and its fatty acids with parietal cells and gastric $\mathrm{H}^{+} / \mathrm{K}^{+}$-ATPase. Gut 1994;25:1176-80.

125. Dixon M. Acid, ulcers, and H.pylori. Lancet 1993;ii:384-385.

126. Karttunen T, Niemalä S, Lehtola J. Helicobacter pylori in dyspeptic patients: quantitative association with severity of gastritis, intragastric $\mathrm{pH}$, and serum gastrin concentration. Scand J Gastroenterol 1991;26(S 186):124-34.

127. Louw JA, Falck V, van Rensburg C, Zak J, Adams G, Marks IN. Distribution of Helicobacter pylori colonisation and associated gastric inflammatory changes: difference between patients with duodenal and gastric ulcers. J Clin Pathol 1993;46:754-6.

128. Lee A, Dixon MF, Danon SJ, Kuipers E, Megraud F, Larsson H, et al. Local acid production and Helicobacter pylori: a unifying hypothesis. Eur J Gastroenterol Hepatol 1995; $7: 461-5$.

129. Strickland RG, Mackay IR. A reapraissal of the nature and significance of chronic atrophic gastritis. Am J Dig Dis 1973;18:426-0.

130. Correa P. Chronic gastritis. In : Whitehead R, editor. Gastrointestinal and Oesophageal Pathology. London: Churchill Livingstone, 1989:402-20.

131. Whitehead R, Truelove SC, Gear MWL. The histological diagnosis of chronic gastritis in fibreoptic gastroscope biopsy specimens. J Clin Pathol;1972;25:1-11.

132. Whitehead $R$. The classification of chronic gastritis: current status. J Clin Gastroenterol 1995;21(S 1):131-4.

133. Yardley $\mathrm{JH}$. Pathology of chronic gastritis and duodenitis. In: Goldman $\mathrm{H}$, Appelman HD, Kaufman N, editors. Gastrointestinal Pathology. Baltimore, MD: Williams \& Wilkins, 1990:69-143.

134. Price $A B$. The Sydney System: Histological division. J Gastroenterol Hepatol 1991;6:209-22.

135. Sipponen P, Kekki M, Siurala M. Sydney System: Epidemiology and natural history of chronic gastritis. J Gastroenterol Hepatol 1991;6:244-51.

136. Misiewicz JJ. The Sydney System: a new classification of gastritis. Introduction. J Gastroenterol Hepatol 1991;6:207-8.

137. Dixon MF, Genta RM, Yardley JH, Correa P. Classification and grading of gastritis. The up-dated Sydney system. Am J Surg Pathol 1996;20:1161-81.

138. Rubin CE. Are there three types of Helicobacter pylori gastritis? Gastroenterology 1997;112:2108-10.

139. Andrew A, Wyatt JI, Dixon MF. Observer variation in the assessment of chronic gastritis according to the Sydney system. Histopathology 1994;25:317-22. 
140. Genta RM. Recognizing atrophy: another step toward a classification of gastritis. Am J Surg Pathol 1996;20(S 1):23-30.

141. Genta RM. Can atrophic gastritis be diagnosed in the presence of Helicobacter pylori infection? In: Hunt RH, Tytgat GNJ, editors. Helicobacter pylori. Basic Mechanisms to Clinical Cure. Dordrecht: Kluwer Academic Publishers 2000;22937.

142. Veldhuyzen van Zanten SOJ, Dixon MF, Lee A. The gastric transitional zones: neglected links between gastroduodenal pathology and Helicobacter ecology. Gastroenterology 1999;116:1217-29.

143. Ferrero $\mathrm{RL}$, Lee $\mathrm{A}$. The importance of urease in in acid protection for the gastriccolonising bacteria H.pylori and H.felis sp. nov. Microbiol Ecol Health Dis 1991;4:121-34.

144. Meyer-Rosberg K, Scott DR, Melchers K, Sachs G. The effect of environmental pH on the proton motive force of H.pylori. Gastroenterology 1996;111:886-900.

145. Rektorsheck M, Weeks D, Sachs G, Melchers K. Influence of pH on metabolism and urease activity of Helicobacter pylori. Gastroenterology 1998;115:628-41.

146. Weeks DL, Eskandari S, Scott DR, Sachs G. A H ${ }^{+}$-gated urea channel: the link between Helicobacter pylori urease and gastric colonization. Science 2000;287:482-5.

147. Scott DR, Marcus EA, Weeks DL, Lee A, Melchers K, Sachs G. Expression of the Helicobacter pylori urel gene is required for acidic $\mathrm{pH}$ activation of cytoplasmic urease. Infect Immun 2000;68:470-7.

148. Logan RP, Walker MM, Misiewicz JJ, Gummett PA, Karim QN, Baron JH, et al. Changes in the intragastric distribution of H.pylori during treatment with omeprazole. Gut 1995;36:12-6.

149. Solcia E, Villani L, Fiocca R, Luinetti O, Boldorini R, Trespi E, et al. Effect of eradication of Helicobacter pylori on gastritis in duodenal ulcer patients. Scand $J$ Gastroenterol 1994;29(S 201):28-34.

150. Vigneri S, Termini R, Scialabba A, Pisciotta G, Di Mario F. Omeprazole therapy modifies the gastric localization of Helicobacter pylori [letter]. Am J Gastroenterol 1991;86:1276-7.

151. Hui WM, Lam SK, Ho J, lai CL, Lok AS, Ng MM, et al. Effect of omeprazole on duodenal ulcer associated antral gastritis and Helicobacter pylori. Dig Dis Sci $1991 ; 36: 577-82$.

152. Roland $M$, Berstad $A$, Liavåg I. A histological study of gastric mucosa before and after proximal vagotomy in duodenal ulcer patients. Scand $\mathrm{J}$ Gastroenterol 1975;10:181-6.

153. Äärimaa M, Söderström KO, Kalimo H, Inberg M. Morphology and function of the parietal cells after proximal selective vagotomy in duodenal ulcer patients. Scand $J$ Gastroenterol 1984;19;787-97.

154. Peetsalu A, Maaroos HI, Sipponen P, Peetsalu M. Long-term effect of vagotomy on gastric mucosa and Helicobacter pylori in duodenal ulcer patients. Scand J Gastroenterol 1991;26(S 186):77-83.

155. Ihamäki T, Saukkonen M, Siurala M. Long-term observation of subjects with normal mucosa and with superficial gastritis: results of a 23-27 years' follow-up examinations. Scand J Gastroenterol 1978;13:771-5.

156. Correa P, Haenszel W, Cuello C, Zavala D, Fontham E, Zarama G, et al. Gastric precancerous process in a high risk population: cohort follow-up. Cancer Res 1990;50:4737-40.

157. Villako K, Kekki M, Maaroos HI, Sipponen P, Uibo R, Tammur R, et al. Chronic gastritis: progression of inflammation and atrophy in a six-year follow-up of a random sample of 142 Estonian urban subjects. Scand J Gastroenterol 1991;26(S 86):135-41. 
158. Kuipers EJ, Uyterlinde AM, Nelis GF, Meijer CJLM, Peña AS, Meuwissen SGM. Long-term follow-up of Helicobacter pylori associated gastritis. Gastroenterology 1994;106(4):A113.

159. Jönsson KA, Ström M, Bodemar G, Norrby $K$. Histologic changes in the gastroduodenal mucosa after long-term medical treatment with cimetidine or parietal cell vagotomy in duodenal ulcer disease. Scand J Gastroenterol 1988;23:433-41.

160. Meining A, Bosseckert $H$, Caspary WF, Nauert C, Stolte M. $H_{2}$-receptor antagonists and antacids have an aggravating effect on Helicobacter pylori gastritis in duodenal ulcer patients. Aliment Pharmacol Ther 1997;11:;729-34.

161. Berstad AE, Hatlebakk JG, Maartmann-Moe $H$, Berstad A. Brandtzaeg $P$. Helicobacter pylori gastritis and epithelial cell proliferation in patients with reflux oesophagitis after treatment with lansoprazole. Gut 1997;41:740-7.

162. Stolte M, Meining A, Schmitz JM, Alexandridis T, Siefert E. Changes in Helicobacter pylori-induced gastritis in the antrum and corpus during 12 months of treatment with omeprazole and lansoprazole in patients with gastro-oesophageal reflux disease. Aliment Pharmacol Ther 1998;12:247-53.

163. Moayyedi P, Wason C, Peacock R, Walan A, Bardhan K, Axon ATR, et al. Changing patterns of H.pylori gastritis in long-standing acid suppression. Helicobacter 2001;5(4);206-14.

164. Kuipers EJ, Lee A, Klinkenberg-Knol EC, Meuwissen SGM. Review article: The development of atrophic gastritis - Helicobacter pylori and the effects of acid suppressive therapy. Aliment Pharmacol Ther 1995;9:331-40.

165. Athmann C, Mander I, Brunner G, Ng W, Heinze H, Fischer R, et al. Histology and safety parameters during long-term maintenance treatment with pantozole in severe acid-peptic disease. Gastroenterology 1998;114:A60.

166. Lundell L, Miettinen P, Myrvol HE, Pedersen SA, Thor K, Andersson A, et al. Lack of effect of acid suppression therapy on gastric atrophy. Gastroenterology 1999;117:319-26.

167. Diebold MD, Richardson S, Duchateau A, Bigard MA, Colin R, Cortot A, et al. Factors influencing corpus argyrophil cell density and hyperplasia in reflux esophagitis patients treated with antisecretory drugs and controls. Dig Dis Sci 1998;43(No.8):1629-35.

168. Hirschowitz BI, Haber MM. Helicobacter pylori effects on gastritis, gastrin enterochromaffin-like cells in Zollinger-Ellison syndrome and non-Zollinger-Ellison syndrome acid hypersecretors treated long-term with lansoprazole. Aliment Pharmacol Ther 2001;15:87-103.

169. Vetvik K, Schrumpf E, Mowinckel P, Ase S, Andersen KL. Effects of omeprazole and eradication of Helicobacter pylori on gastric and duodenal mucosal enzyme activities and DNA in duodenal uicer patients. Scand J Gastroenterol 1994;29:9951000.

170. Hackelsberger A, Miehlke S, Len N, et al. Helicobacter pylori eradication vs shortterm acid suppression: long term consequences for gastric body mucosa. Gastroenterology 1996;110:A127.

171. Meining AG, Bayerdorffer E, Stolte M. Helicobacter pylori gastritis of the gastric cancer phenotype in relatives of gastric carcinoma patients. Eur $J$ Gastroenterol Hepatol 1999;11:17-20.

172. Sipponen P, Kekki M, Haapakoski J, Ihamäki T, Siurala M. Gastric cancer risk in chronic atrophic gastritis: statistical calculations of cross-sectional data. Int $\mathrm{J}$ Cancer 1985;35:173-7.

173. Pounder RE, Williams MP. Omeprazole and accelerated onset of atrophic gastritis. Gastroenterology 2000;118:238-9.

174. McColl KEL, Murray LS, Gillen D. Omeprazole and accelerated onset of atrophic gastritis. Gastroenterology 2000;118:239. 
175. Kuipers EJ, Klinkenberg-Knol EC, Meuwissen SGM. Omeprazole and accelerated onset of atrophic gastritis. Gastroenterology 2000;118:239-40.

176. Stolte M, Meining A. Lack of effect of acid suppression therapy on gastric atrophy. Gastroenterology 2000;118:242-3.

177. Kuipers EJ, Meuwissen SGM. Long-term proton pump inhibitor therapy accelerates the onset of atrophic gastritis in Helicobacter pylori-positive patients. In: Hunt RH, Tytgat GNJ, editors. Helicobacter pylori. Basic Mechanisms to Clinical Cure. Dordrecht: Kluwer Academic Publishers 2000;255-67.

178. Schenk BE, Kuipers EJ, Nelis GF, Bloemena E, Thijs JC, Snel P, et al. Effect of Helicobacter pylori eradication on chronic gastritis during omeprazole therapy. Gut 2000;46:615-21.

179. Fenwick S. On atrophy of the stomach. Lancet $1870 ; 2: 78-80$.

180. Kuipers EJ, Perez-Perez GI, Meuwissen SGM, Blaser MJ. Helicobacter pylori and atrophic gastritis: Importance of the cagA status. J Natl Cancer Inst 1995;87:177780.

181. Sozzi M, Valentini M, Figura N, De Paoli P, Tedeschi RM, Gloghini A, et al. Atrophic gastritis and intestinal metaplasia in Helicobacter pylori infection: The role of cagA status. Am J Gastroenterol 1998;93:375-9.

182. Maaroos HI, Vorobjova T, Sipponen $P$, Tammur R, Uibo R, Wadström $T$, et al. An 18-year follow-up study of chronic gastritis and Helicobacter pylori: association of $\operatorname{cag} A$ positivity with development of atrophy and activity of gastritis. Scand $\mathrm{J}$ Gastroenterol 1999;34:864-9.

183. Warburton VJ, Everett S, Mapsone NP, Axon AT, Hawkey P, Dixon MF. Clinical and histological association of cagA and vacA genotypes in Helicobacter pylori gastritis. J Clin Pathol 1998;51:55-61.

184. El-Omar EM, Carrington M, Chow WH, McColl KEL, Bream JH, Young HA, et al. Interleukin-1 polimorphisms associated with increased risk of gastric cancer. Nature 2000;404:398-402.

185. Nomura A, Yamakawa H, Ishidate T, Kamiyama S, Masuda H, Stemmermann GN, et al. Intestinal metaplasia in Japan: association with diet. J Natl Cancer Inst 1982;68:401-5.

186. Kneller RW, You WC, Chang YS, Liu WD, Zhang L, Zhao L, et al. Cigarette smoking and other risk factors for progression of precancerous stomach lesions. $J$ Natl Cancer Inst 1992;84:1261-6.

187. Sipponen P, Kekki M, Seppälä K, Siurala M. The relationships between chronic gastritis and gastric acid secretion. Aliment Pharmacol Ther 1996;10(S 1):103-8.

188. Suzuki M, Miura S, Suetmatsu M, Fakumura D, Kurose K, Suzuki H, et al. Helicobacter pylori-associated ammonia production enhances neutrophildependent gastric mucosal cell injury. Am J Physiol 1992;263:G719-25.

189. Tsujii M, Kavano S, Tsujii S, Fusamoto H, Kamada T, Sato N. Mechanism of gastric mucosal damage induced by ammonia. Gastroenterology 1992;102:1881-8.

190. Ricci V, Sommi P, Fiocca R, Cova E, Figura N, Romano M, et al. Cytotoxicity of Helicobacter pylori on human gastric epithelial cells in vitro: role of cytotoxin(s) and ammonia. Eur J Gastroenterol Hepatol 1993;5:687-94.

191. Suzuki M, Suzuki H, Nagahashi S, Mori M, Kitahora T, Ishii H. Myeloperoxidase content and hypochlorous anion production increased in H.pylori-infected corpus mucosa after PPI treatment. Gastroenterology 1999;116:A4210.

192. Suzuki H, Yanaka A, Shibahara T, Muto M, Murata Y, Matsui $H$, et al. Effects of ammonia, hypochloric acid on gastric mucosal barrier function at different luminal $\mathrm{pH}$. Gastroenterology 1999;116:A4211.

193. Väkeväinen S, Tillonen J, Salaspuro M, Jousimies-Somer H, Nuutinen H, Färkkilä M. Hypochlorhydria induced by a proton pump inhibitor leads to intragastric microbial production of acetaldehyde from ethanol. Aliment Pharmacol Ther 2000;14:1511-8. 
194. Homann N, Kärkkäinen P, Koivisto T, Nosova T, Lokelainen K, Salaspuro M. Effects of acetaldehyde on cell regeneration and differentiation of the upper gastrointestinal tract mucosa. J Natl Cancer Inst 1997;89:1692-7.

195. Negrini R, Lisato L, Zanella I, Cavazzini L, Gullini S, Villanacci V, et al. Helicobacter pylori infection induces antibodies cross-reacting with human gastric mucosa. Gastroenterology 1991;101:437-45.

196. Negrini R, Savio A, Poiesi C, Appelmelk BJ, Buffoli F, Paterlini A, et al. Antigenic mimicry between Helicobacter pylori and gastric mucosa in the pathogenesis of body atrophic gastritis. Gastroenterology 1996;111:655-65.

197. Faller G, Steininger H, Kränzlein J, Maul H, Hensen J, Hahn EG, et al. Antigastric autoantibodies in Helicobacter pylori infection: implications of histological and clinical parameters of gastritis. Gastroenterology 1997;41:619-23.

198. Claeys D, Faller G, Appelmelk BJ, Negrini R, Kirschner T. The gastric $\mathrm{H}^{+}, \mathrm{K}^{+}-$ ATPase is a major autoantigen in chronic Helicobacter pylori gastritis with body mucosa atrophy. Gastroenterology 1998;115:340-7.

199. Sagar M, Tybring G, Dahl ML, Bertilsson L, Seensalu R. Effects of omeprazole on intragastric $\mathrm{pH}$ and plasma gastrin are dependent on the CYP2C19 polymorphism. Gastroenterology 2000;119:670-6.

200. Wang TC, Dangler CA, Chen D, Goldenring JR, Koh T, Raychowdhury R, et al. Synergistic interaction between hypergastrinemia and Helicobacter infection in a mouse model of gastric cancer. Gastroenterology 2000;118:36-47. 


\section{Chapter 2}

Aims and outline of the thesis 


\section{Aims and outline of the thesis}

Currently, there is a large body of information regarding the gastrointestinal effects of acid-suppressive therapy. Most of these studies examined hypergastrinaemia and ECL cell proliferation; intragastric bacterial overgrowth and its consequences; and development of atrophic gastritis in the presence of H.pylori infection as distinct issues. Hitherto, the interrelation between the aforementioned phenomena has received little attention.

The research described in this thesis focuses on the development of chronic atrophic gastritis and proliferation of the ECL cells during treatment with acid-suppressive medication. Particular attention was paid to the role of intragastric H.pylori and non-H.pylori bacteria in this development. The clinical utility of serological markers for these conditions was also investigated.

We addressed the following issues:

- Does medium- and long-term treatment with acid-suppressive medication result in stimulation of the gastric ECL cell population? If so, is serum chromogranin $\mathrm{A}(\mathrm{CgA})$ a useful marker to monitor these changes?

- Is there a relationship between gastric luminal and mucosal overgrowth of non-H.pylori bacteria during acid-suppressive therapy, and which factors influence their occurrence?

- Is the gastric double infection with H.pylori and non-H.pylori bacteria during acid-suppressive therapy associated with an increased risk for development of atrophic gastritis? If this is the case, could such development be due to an enhanced pro-inflammatory cytokine response?

- Is serum pro-inflammatory cytokine profile of additional value to serum gastrin, and serum pepsinogens measurement in screening for atrophic body gastritis?

To answer these questions, we have investigated a series of 230 consecutive dyspeptic patients referred for upper gastrointestinal endoscopy to the open-access unit of the University Hospital Maastricht, between January 1997 and June 1998. They were patients with gastro-oesophageal reflux disease, receiving acid-suppressive medication, and non-treated dyspeptic controls, with normal endoscopic findings. 


\section{Chapter 3}

Serum gastrin and chromogranin $\mathrm{A}$ during medium- and long-term acid suppressive therapy: a case-control study

S Sanduleanu, M. Stridsberg, D Jonkers, W Hameeteman, I Biemond, G Lundqvist, C Lamers, RW Stockbrügger 


\section{Abstract}

\section{Background \& Aim}

Serum chromogranin $\mathrm{A}(\mathrm{CgA})$ is regarded as a reliable marker of neuroendocrine proliferation. We previously described increased serum $\mathrm{CgA}$ levels during short-term profound gastric acid inhibition. In the present study we investigated serum gastrin and $\mathrm{CgA}$ levels in dyspeptic patients during continuous medium (6 weeks to 1 year)- or longterm (1 year to 8 years) gastric acid suppressive therapy.

\section{Patients \& Methods}

114 consecutive dyspeptic patients referred for upper Gl-endoscopy were enrolled in a cross-sectional, case-control study [62 patients on continuous antisecretory therapy, either with proton pump inhibitors (PPIs) $(n=47)$ or $\mathrm{H}_{2}$-receptor antagonists $\left(\mathrm{H}_{2} \mathrm{RAs}\right)$ $(n=15)$ for gastro-oesophageal reflux disease with or without Barrett's oesophagus or functional dyspepsia, and 52 age- and sex-matched patients without medical acid inhibition and with normal endoscopic findings (control group)]. Doses of omeprazole ranged from $20 \mathrm{mg}$ to $80 \mathrm{mg}$ daily and ranitidine from $150 \mathrm{mg}$ to $450 \mathrm{mg}$ daily. Fasting serum $\mathrm{CgA}$ and serum gastrin levels were measured by radioimmunoassay (reference values: serum $\mathrm{CgA}<4.0 \mathrm{nmol} / \mathrm{l}$; serum gastrin $<85 \mathrm{ng} / \mathrm{l}$ ). H.pylori serology was assessed by Western blotting.

\section{Results}

Fasting serum $\mathrm{CgA}$ levels positively correlated with serum gastrin in the entire study population ( $r=0.55, P=0.0001$ ). Median serum $\mathrm{CgA}$ values were higher in patients treated with PPIs vs $\mathrm{H}_{2}$ RAs [2.8 (2-5.9) $\mathrm{nmol} / \mathrm{l}$ vs $\left.2(1.9-2.3) \mathrm{nmol} / \mathrm{l}, \mathrm{P}<0.002\right]$ and controls $[2.8(2-5.9) \mathrm{nmol} / \mathrm{l}$ vs $1.8(1.5-2.2) \mathrm{nmol} / \mathrm{l}, \mathrm{P}<0.0001)$ and did not differ between patients treated with $\mathrm{H}_{2}$ RAs and controls. Serum gastrin and $\mathrm{CgA}$ levels in patients on PPI therapy positively correlated with the degree and duration of acid inhibition. Patients on long-term PPI therapy had significantly higher fasting serum gastrin and $\mathrm{CgA}$ than those on medium-term PPI therapy $[127$ (73-217) ng/l vs 49 (29-78) ng/l, $P<0.0001$ and $4.8(2.8-8) \mathrm{ng} / \mathrm{l}$ vs $2.1(1.9-2.6) \mathrm{ng} / \mathrm{l}, \mathrm{P}<0.001]$. No such relation was found in patients on medium- vs long-term $\mathrm{H}_{2} \mathrm{RAs}$. Overall, patients with positive H.pylori serology had higher serum gastrin and $\mathrm{CgA}$ levels than those with negative H.pylori serology [51 (27119) ng/l vs 27 (14-79) ng/l, $\mathrm{P}=0.01 ; 2.4(1.9-3.4) \mathrm{nmol} / \mathrm{l}$ vs $2.0(1.7-2.5) \mathrm{nmol} / \mathrm{l}, \mathrm{P}=0.05]$.

\section{Conclusions}

During long-term continuous PPI treatment, serum gastrin and $\mathrm{CgA}$ leveis are significantly elevated compared to $\mathrm{H}_{2} \mathrm{RA}$ treatment and non-treated dyspeptic controls. H.pylori infection seems to affect gastric ECL cell secretory function. Increased serum $\mathrm{CgA}$ values during long-term profound gastric acid inhibition could reflect either gastric enterochromaffin-like cell hyperfunction or proliferative changes. 


\section{Introduction}

It is widely accepted that profound acid inhibition leads to antral gastrinproducing $(G)$ cell hyperplasia and hypergastrinaemia ${ }^{1,2}$. Gastrin has a specific effect on the enterochromaffin-like (ECL) cell, regulating its function and promoting its growth ${ }^{3-5}$. In rats, gastric carcinoids may occur after long-term acid suppression ${ }^{6-10}$. However, in humans, the development of gastric ECL cell carcinoids in response to chronic hypergastrinaemia has been restricted to patients with the ZollingerEllison syndrome (ZES) as a part of multiple endocrine neoplasia (MEN) - type $\mathrm{I}^{11-13}$ or with chronic atrophic gastritis type $A(A-C A G)^{14-17}$, pointing towards the involvement of additional, and yet unidentified factors. The genomic events associated with MEN-I-ZES, e.g. the loss of a suppressor oncogene in $11 q 13$ or the intragastric environmental changes due to achlorhydria in type A CAG, might explain gastric endocrine cell proliferation in these particular situations ${ }^{18-20}$.

Well-documented prospective studies, focused on the safety of longterm profound medical acid inhibition, do not substantiate the risk of carcinoid tumour formation ${ }^{21-24}$. Recently, the combined effects of profound gastric acid inhibition and Helicobacter pylori (H.pylori) infection on serum gastrin levels have elicited research interest ${ }^{25-28}$. In a follow-up study designed to assess serum gastrin levels and gastric endocrine and non-endocrine mucosal changes during five-year treatment with lansoprazole, H.pylori infection was regarded as a risk factor for the progression of fundic gastritis and the development of $E C L$ cell hyperplasia ${ }^{29}$.

Taking into consideration the slow rate of progression from hyperplasia to dysplasia and to carcinoid tumour formation, it seems premature to conclude that ECL cell proliferation due to pharmacologically induced hypergastrinaemia is an innocuous phenomenon and that clinical surveillance is unnecessary. Moderate gastrin elevations exert constant trophic effect on the ECL cells and the clinical consequences of this over many years warrant further consideration $^{30-32}$.

The identification of a noninvasive, accurate biochemical marker of the ECL cell function and growth is therefore an important issue for clinical practice and research ${ }^{30,33}$. Recent studies have described serum chromogranin $A(\mathrm{CgA})$ as a reliable marker of neuroendocrine cell proliferation $^{34-38}$. Increased serum $\mathrm{CgA}$ concentrations have been reported in patients with gastrinoma ${ }^{39-40}$, as well as in patients with type A autoimmune gastritis ${ }^{41}$. Waldum et al. described elevated serum CgA levels after short-term treatment with omeprazole, suggesting its 
possible use as a test to evaluate ECL cell hyperplasia in patients with hypergastrianaemia secondary to acid inhibition ${ }^{42}$. Our group has also shown that after short-term medical acid inhibition with three different drug regimens (ranitidine $300 \mathrm{mg}$ b.d., omeprazole $20 \mathrm{mg}$ o.m., omeprazole $40 \mathrm{mg}$ o.m.) in healthy volunteers, serum gastrin and chromogranin A increase in relation to the degree of acid inhibition and that they are strongly correlated ${ }^{43}$.

The present study was performed to investigate the relationship between serum gastrin and $\mathrm{CgA}$ levels during medium- and long-term profound acid inhibition. The influence of Helicobacter pylori infection on serum gastrin and chromogranin A levels, in these circumstances, was evaluated as well.

\section{Subjects and methods}

\section{Subjects}

One hundred and fourteen consecutive dyspeptic patients $(F=52, M=62)$ referred for open-access upper gastrointestinal endoscopy between January and August 1997 were enrolled in a cross-sectional, casecontrol study. All subjects had given informed consent prior to inclusion. The mean age was 50 years, with a range of 19-75 years. The study group consisted of 62 patients on continuous medium- (6 weeks to 1 year) or long-term (1 year to 8 years) acid suppressive therapy for gastro-oesophageal reflux disease (GORD) with or without Barrett's oesophagus, or for functional acid dyspepsia. The control group consisted of 52 dyspeptic patients with similar distribution of age and gender, who did not receive acid suppressive medication or antacids before referral and who had normal endoscopic findings.

Patients with active or previous peptic ulcer disease, those who had received $H$.pylori eradication therapy or had undergone previous gastric surgery / vagotomy were not included in the study population. Patients with other gastrointestinal or pancreatic diseases, with known malignancies, endocrine or autoimmune diseases, liver or kidney disorders were not eligible.

The study was approved by the medical ethical committee of the University Hospital Maastricht.

\section{Study design}

After informed consent, an extensive medical history was obtained in all patients and the clinical symptoms, type and daily dose of medication, duration of continuous acid inhibition in the recent years, regularity of 
drug use and eventual comorbidity / comedication or family history of gastric cancer were rigorously recorded.

Endoscopy was performed after an overnight fast with standard gastroscopes (Pentax EG-2901). At the beginning of the endoscopy, a $5-10 \mathrm{ml}$ sample of gastric juice was obtained through the suction channel of the endoscope into a trap placed in the suction line. Fasting gastric juice $\mathrm{pH}$ was immediately measured, using $\mathrm{pH}$-paper strips with grading steps of 0.5 , from $\mathrm{pH} 0$ to $\mathrm{pH} 14$ (Schleicher \& Schüll $\mathrm{GmbH}$; Dassel, Germany) ${ }^{44}$. A $10 \mathrm{ml}$ venous blood sample was collected from all subjects for the assessment of fasting serum gastrin, serum chromogranin A and H.pylori serology.

\section{Determination of serum gastrin levels}

Fasting blood samples were immediately centrifuged and the sera were stored at $-80^{\circ} \mathrm{C}$ until further analysis. The serum gastrin concentration was measured by a radioimmunoassay method using an antibody raised in a rabbit against synthetic unsulphated human gastrin 2-17 covalently coupled to bovine serum albumin as previously described ${ }^{45}$. The antibody binds to all known circulating gastrin fragments. The upper limit of the normal range for fasting state was $85 \mathrm{ng} / \mathrm{l}$.

\section{Determination of serum chromogranin A levels}

A sensitive and specific radioimmunoassay method was used for the determination of chromogranin A levels in the serum samples ${ }^{35,36}$. Polyclonal antibodies raised in rabbits against a fragment of chromogranin A (CgA 116-439) purified from the urine of a patient with carcinoid tumour were used in the assay. Based on a group of healthy individuals, the upper limit of the normal range for fasting serum chromogranin A levels was $4 \mathrm{nmol} / \mathrm{l}$.

\section{Helicobacter pylori serology}

A commercial Western blotting for IgG (Helicoblot 2.0, Imphos BV, Zambon Group, Amersfoort, The Netherlands) was used for serological assessment of H.pylori. Bands were present for 19.5, 26.5, 30, 35, 89 $(\operatorname{vacA})$, and $116 \mathrm{kD}(\mathrm{cagA})$ proteins. The patients were considered to be positive if two bands of the $19.5,26.5$, or $30 \mathrm{kD}$ protein or any of the bands among the 35,89 , or $116 \mathrm{kD}$ proteins were positive. H.pylori positive and H.pylori negative control sera were included at each determination. 


\section{Statistical evaluation}

Statistical analysis was performed using the SPSS software package. As the data were not normally distributed, values were expressed as medians, with $25-75 \%$ quartile ranges and group comparisons were performed using non-parametric tests. The Kruskal-Wallis test was used for multiple comparisons and the Mann-Whitney $U$ test for two group comparisons of continuous variables. Differences in dichotomous variables were evaluated using the $\chi^{2}$-test or the Fisher's exact test, depending on the number of patients. Correlations were performed with the Spearman rank test. In addition, linear regression analysis was used to assess the relationship between serum gastrin, $\mathrm{CgA}$, and the duration of PPI therapy. Two-sided P-values $<0.05$ were assumed to indicate statistical significance.

\section{Results}

\section{Study population}

Table 3.1 illustrates the clinical features of the study population, subdivided according to acid inhibition regimen. There was a similar distribution of age and gender among the three subgroups of patients. Omeprazole doses ranged from $20 \mathrm{mg}$ to $80 \mathrm{mg}$ daily and of ranitidine from $150 \mathrm{mg}$ to $450 \mathrm{mg}$ daily. The median length of acid inhibition therapy in the group receiving $\mathrm{H}_{2}$ RAs $(n=15)$ was 2.4 years (range 6 weeks-10 years) and in patients on PPIs $(n=47)$ was 1.8 years (range 6 weeks-8 years). In patients on long-term PPIs $(n=26)$ the median duration on therapy was 2.8 years (1-8 years). Eight of these 26 patients $(30 \%)$ were continuously treated for 1 to 2 years, $7(27 \%)$ for 2 to 3 years, $5(20 \%)$ for 3 to 4 years, and $6(23 \%)$ for more than 4 years. In patients on long-term $\mathrm{H}_{2} \mathrm{RAs}(\mathrm{n}=8)$ the median duration on therapy was 3.2 years (1-10 years). Two (25\%) of them received continuous therapy with $\mathrm{H}_{2} \mathrm{RAs}$ for 1 to 2 years, $2(25 \%)$ for 2 to 3 years, $3(38 \%)$ for 3 to 4 years, and 1 (12\%) for about 10 years. 
Table 3.1. Clinical characteristics of the study population subdivided according to the regimen of acid inhibition.

\begin{tabular}{|c|c|c|c|}
\hline Characteristics & $\begin{array}{l}\text { Control group } \\
(n=52)\end{array}$ & $\begin{array}{c}H_{2} \text { RA group } \\
\quad(n=15)\end{array}$ & $\begin{array}{c}\text { PPI group } \\
(n=47)\end{array}$ \\
\hline Median age, (range) years & $48.2(19-75)$ & $52.7(32-72)$ & $51.0(28-72)$ \\
\hline Gender $(\bar{M} / F)$ & $26 \mathrm{M} / 26 \mathrm{~F}$ & $9 \mathrm{M} / 6 \mathrm{~F}$ & $27 \mathrm{M} / 20 \mathrm{~F}$ \\
\hline \multicolumn{4}{|l|}{$\begin{array}{l}\text { Treatment duration } \\
\text { (no. patients) }\end{array}$} \\
\hline -medium-term & - & $7(46.7 \%)$ & $21(44.6 \%)$ \\
\hline -long-term† & & $8(53.3 \%)$ & $26(55.4 \%)$ \\
\hline \multicolumn{4}{|l|}{$\begin{array}{l}\text { Dose of medication } \\
\text { (no. patients) }\end{array}$} \\
\hline \multicolumn{4}{|l|}{$\mathrm{H}_{2} \mathrm{RAs}$} \\
\hline 150 mg daily & & & - \\
\hline 300 mg daily & & $3(20 \%)$ & \\
\hline$>300$ mg daily & - & $10(69 \%)$ & \\
\hline $\mathrm{PPIs}$ & & $2(11 \%)$ & \\
\hline 20 mg daily & & & $32(68 \%)$ \\
\hline 40 mg daily & - & - & $13(27 \%)$ \\
\hline$>40 \mathrm{mg}$ daily & & & $2(5 \%)$ \\
\hline \multicolumn{4}{|l|}{ Endoscopic findings } \\
\hline GORD \pm Barrett oesophagus & - & $6(40 \%)$ & $20(42.6 \%)$ \\
\hline Erosive gastritis & $11(21 \%)$ & $5(33.3 \%)$ & $13(27.6 \%)$ \\
\hline Normal findings & $41(79 \%)$ & $4(26.7 \%)$ & $14(29.8 \%)$ \\
\hline
\end{tabular}

${ }^{\star} 6$ weeks- 1 year; $\dagger 1$ year-8 years.

\section{Fasting intragastric $\mathrm{pH}$ in relation to basal serum gastrin and chromogranin A}

The degree of gastric acid inhibition during endoscopy, as measured by the fasting intragastric $\mathrm{pH}$, was higher in patients on $\mathrm{PPI}$ therapy compared to those on $\mathrm{H}_{2} \mathrm{RA}$ therapy or controls and did not differ between patients treated with $\mathrm{H}_{2} \mathrm{RAs}$ and controls (Table 3.2). Moreover, the subset of patients on long-term therapy with PPIs $(n=26)$ showed stronger suppression of gastric acid secretion at the time of endoscopy than the patients on medium-term PPI therapy $(n=21)$ (Table 3.3). No such difference was found between patients on medium- $v$ s long-term $\mathrm{H}_{2}$ RAs.

Basal gastric juice $\mathrm{pH}$ values positively correlated with fasting serum gastrin $(r=0.50 ; P=0.0001)$ and chromogranin $A$ levels $(r=0.37$; $\mathrm{P}=0.0001$ ). 
Table 3.2. Basal serum gastrin, chromogranin $A$, and fasting intragastric $\mathrm{pH}$ in relation to the regimen of medical acid inhibition.

\begin{tabular}{lcccccc}
\hline Characteristics & \multicolumn{2}{c}{$\begin{array}{c}\text { Control group } \\
(\mathbf{n = 5 2})\end{array}$} & $\begin{array}{c}\text { H2RA group } \\
\mathbf{( n = 1 5 )}\end{array}$ & \multicolumn{2}{c}{$\begin{array}{c}\text { PPI group } \\
\text { (n=47) }\end{array}$} \\
\hline Fasting intragastric $\mathrm{pH}$ & 1.75 & $(1.5-3.5)$ & 2.5 & $(1.5-4)$ & 5.5 & $(4-6.5)^{\mathrm{a}}$ \\
Serum gastrin $(\mathrm{ng} / \mathrm{l})$ & 23.5 & $(14.3-34.8)$ & 30 & $(17-35)$ & 79 & $(45-160)^{\mathrm{b}}$ \\
Serum CgA $(\mathrm{nmol} / \mathrm{l})$ & 1.8 & $(1.5-2.2)$ & 2 & $(1.9-2.3)$ & 2.8 & $(2-5.9)^{\mathrm{b}}$ \\
\hline
\end{tabular}

Values are expressed as the median and interquartile ranges; Mann-Whitney $U$ test.

${ }^{\mathrm{a}} \mathrm{P}<0.0003$ vs $\mathrm{H}_{2} \mathrm{RAs}$ and $\mathrm{P}<0.0001$ vs controls

${ }^{\mathrm{b}} \mathrm{P}<0.001$ vs $\mathrm{H}_{2} \mathrm{RAs}$ and $\mathrm{P}<0.0001$ vs controls

${ }^{\mathrm{C}} \mathrm{P}<0.002$ vs $\mathrm{H}_{2}$ RAs and $\mathrm{P}<0.0001$ vs controls.

Table 3.3. Basal serum gastrin, chromogranin $A$, and fasting intragastric $p H$ in relation to the duration of PPI therapy.

\begin{tabular}{lccc}
\hline Characteristics & $\begin{array}{c}\text { Medium-term PPIs } \\
(\mathbf{6} \text { weeks - } \mathbf{1} \text { y) }\end{array}$ & $\begin{array}{c}\text { Long-term PPIs } \\
(\mathbf{1} \mathbf{y}-\mathbf{8} \mathbf{y})\end{array}$ & P-value \\
\hline Number of patients & 21 & 26 & - \\
Median age (range) $(\mathrm{y})$ & $47(27-72)$ & $54(30-70)$ & $\mathrm{NS}$ \\
Gender (M/F) & $13 \mathrm{M} / 8 \mathrm{~F}$ & $14 \mathrm{M} / 12 \mathrm{~F}$ & $\mathrm{NS}$ \\
Fasting intragastric pH & $4(1.5-6.2)$ & $6(4-6)$ & $<0.03$ \\
Serum gastrin (ng/l) & $49(29-78.5)$ & $127(73-217)$ & $<0.0001$ \\
Serum CgA (nmol/) & $2.1(1.9-2.6)$ & $4.8(2.8-8)$ & $<0.001$ \\
\hline
\end{tabular}

Values are expressed as the median and interquartile ranges; Mann-Whitney $U$ test.

\section{Serum gastrin and $\mathrm{CgA}$ measurements}

Serum CgA levels positively correlated with serum gastrin in the entire study population ( $r=0.55, P=0.0001)$. An even stronger correlation $(r=0.76, P=0.0001)$ between serum gastrin and $\mathrm{CgA}$ was found in the PPI group (Figure 3.1).

Basal serum gastrin and $\mathrm{CgA}$ levels were higher in patients taking PPI therapy than in those on $\mathrm{H}_{2}$ RAs or controls but did not differ between patients on $\mathrm{H}_{2}$ RAs and controls (Table 3.2). Serum gastrin and $\mathrm{CgA}$ levels showed a slight and significant increase with the duration of continuous PPI therapy (Figure 3.2a, 3.2b). Likewise, patients on longterm treatment with PPIs ( 1 to 8 years) had significantly higher serum gastrin and $\mathrm{CgA}$ levels compared to those on medium-term (6 weeks to 1 year) PPI therapy (Table 3.3). However, there was no difference with respect to serum gastrin and $\mathrm{CgA}$ between patients on medium- vs long-term therapy with $\mathrm{H}_{2} \mathrm{RAs}[30(15-56) \mathrm{ng} / \mathrm{l}$ vs 28 (17-35) $\mathrm{ng} / \mathrm{l}$, $\mathrm{P}=0.95$ and $2(1.9-2.3) \mathrm{nmol} / \mathrm{l}$ vs $2(1.8-2.3) \mathrm{nmol} / \mathrm{l}, \mathrm{P}=0.78]$.

Serum $\mathrm{CgA}$ levels higher than the reference range were found in 15 of $26(58 \%)$ patients on long-term PPI treatment, 3 of $21(14 \%)$ patients on medium-term PPIs, in none of the patients on $\mathrm{H}_{2} \mathrm{RAs}$ and in 1 of the $52(1.9 \%)$ controls. All patients with $\mathrm{CgA}$ concentrations above the 
reference range had also serum gastrin levels higher than the upper limit of the normal range.

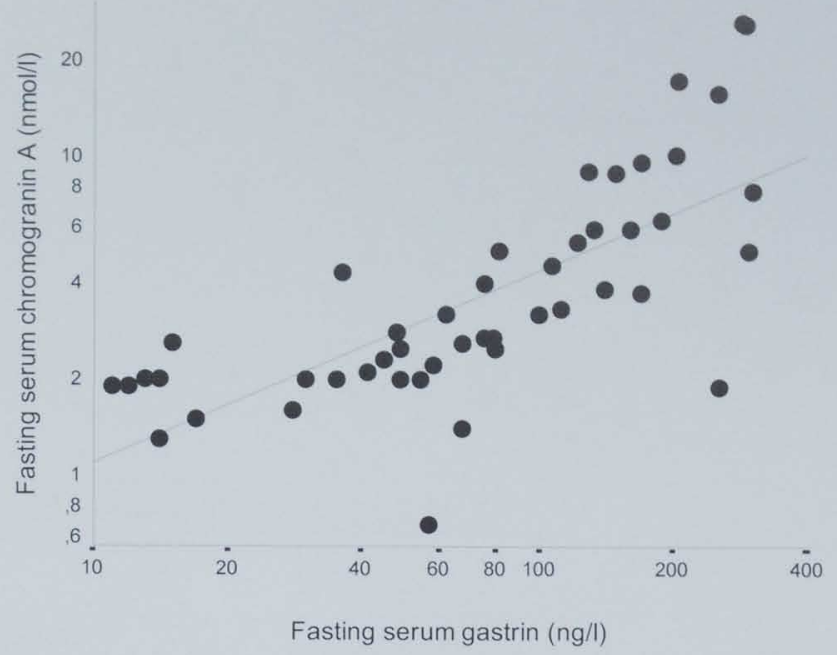

Figure 3.1. Correlation between fasting serum gastrin (ng/l) and chromogranin $A$ $(\mathrm{nmol} / \mathrm{l})$ in 47 patients on PPI treatment $(r=0.76, \mathrm{P}=0.0001)$. Note: the individual data are plotted on a logarithmic scale.

\section{Basal serum gastrin and chromogranin A in relation with H.pylori status}

Among the 114 consecutive dyspeptic patients included in the study, 50 (43.8\%) were H.pylori positive and $64(56.2 \%)$ were H.pylori negative. Twenty-four $(46 \%)$ of the controls, $6(40 \%)$ of the patients on $\mathrm{H}_{2} \mathrm{RAs}$, and $20(43 \%)$ of the patients on PPIs had positive H.pylori serology.

Patients with positive H.pylori serology had higher median fasting serum gastrin and median chromogranin A levels compared to patients with negative H.pylori serology [51 (27-119) ng/l vs 27 (14-79) ng/l, $\mathrm{P}=0.011 ; 2.4(1.9-3.4) \mathrm{nmol} / \mathrm{l}$ vs $2.0(1.7-2.5) \mathrm{nmol} / \mathrm{l}, \mathrm{P}=0.05]$ (Figure 3.3a, 3.3b). 


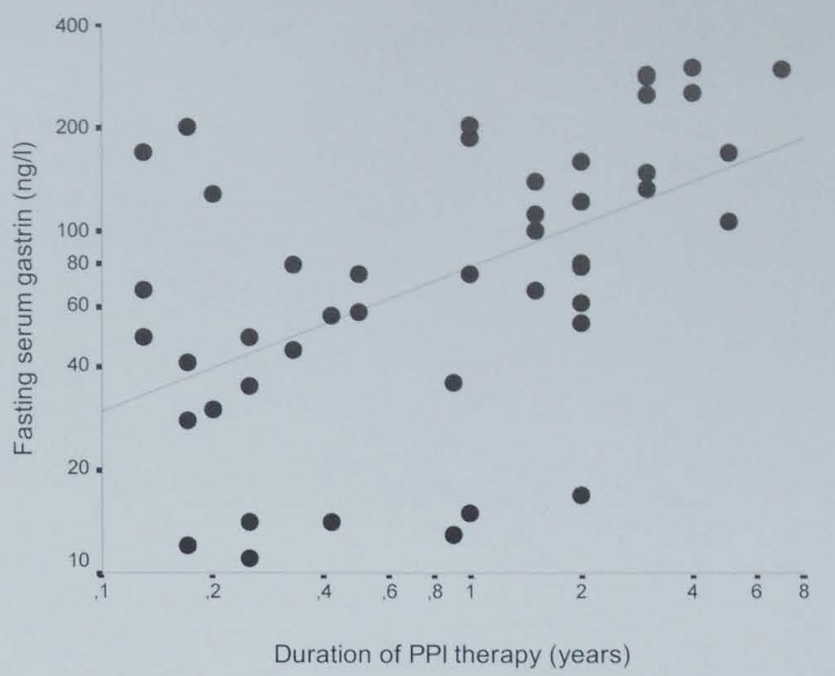

Figure 3.2a. Correlation between fasting serum gastrin levels $(\mathrm{ng} / \mathrm{l})$ and the duration of PPI treatment (years) in 47 patients $(r=0.66, P=0.0001, y=51.7+36 x)$. Note: the individual data are plotted on a logarithmic scale.

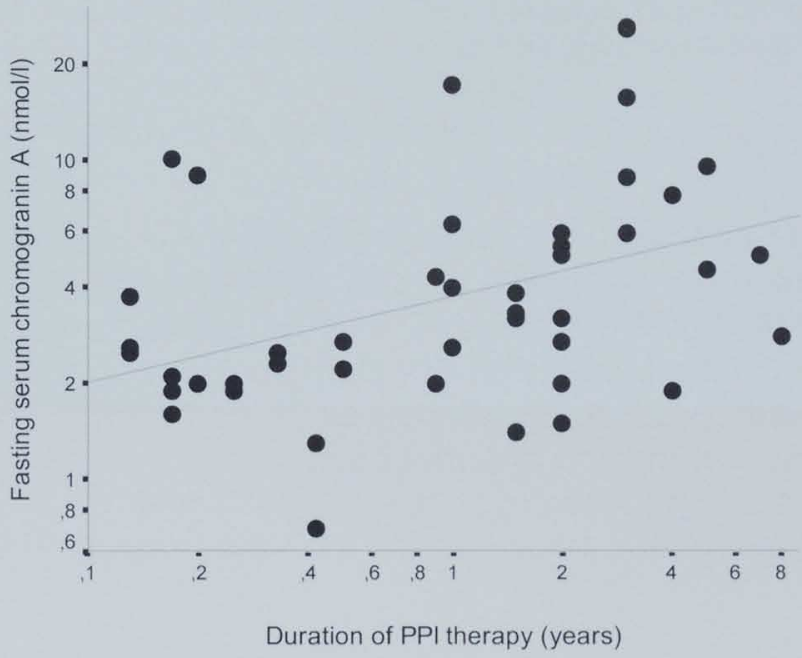

Figure 3.2b. Correlation between fasting serum chromogranin A levels (nmol/I) and the duration of PPI treatment (years) in 47 patients $(r=0.41, P=0.005, y=$ $2.75+1.74 x)$. Note: the individual data are plotted on a logarithmic scale.

\section{Discussion}

Long-term therapy with potent antisecretory drugs results in functional and proliferative changes of gastric enterochromaffin-like cells ${ }^{46}$. 
Although in humans an achlorhydria-carcinoid sequence seems unlikely, the effect of long-term hypergastrinaemia on the endocrine cells of the gastric oxyntic mucosa remains unclear.

(a)

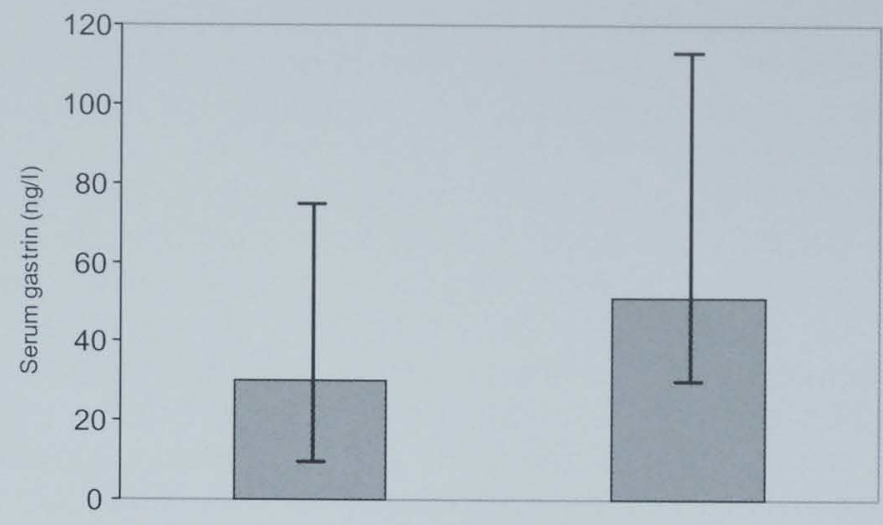

Hp negative

$(n=64)$

Hp positive

$(n=50)$

Figure 3.3a. Fasting serum gastrin levels were higher in H.pylori positive (Western blotting) than in H.pylori negative patients $(P=0.011)$. Median values (interquartile ranges) are shown.

(b)

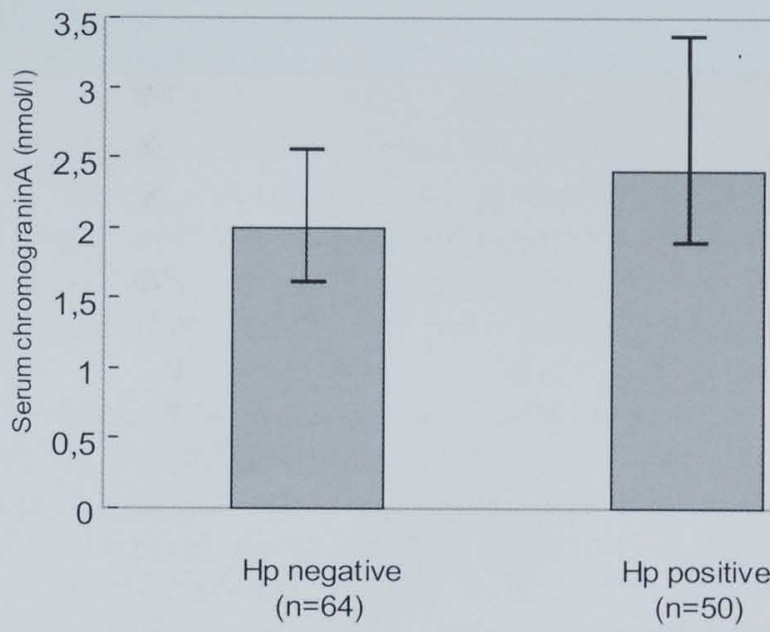

Figure 3.3b. Fasting serum chromogranin A levels were higher in H.pylori positive (Western blotting) than in H.pylori negative patients $(P=0.05)$. Median values (interquartile ranges) are shown. 
The recently described role of ECL cells in the modulation of gastric acid secretion sheds a new light on the pathophysiology of this complex cell population. The ECL cells are thought to increase gastric acid secretion by releasing histamine in response to gastrin stimulation ${ }^{47-49}$. Hence, prolonged hypergastrinaemia might play a central role in the rebound acid hypersecretion after long-term acid inhibition ${ }^{42}$.

The study of gastric endocrine cells based on morphological methods provides unique information about the progression of the hyperplastic changes. However, the accurate evaluation of gastric mucosal endocrine proliferation encounters many limitations in daily clinical practice. Mucosal ECL cell hyperplasia is not endoscopically detectable and, thus, may be under-estimated in routine examinations ${ }^{50}$. The coexistence of parietal cell hypertrophy / hyperplasia due to hypergastrinaemic states ${ }^{51}$, or the presence of H.pylori-related atrophic gastritis with clustering of the endocrine cells are possible confounding factors in the assessment of endocrine cell hyperplasia. Moreover, the use of laborious morphometric methodologies with large variations in expressing the results makes a comparison between different studies difficult.

For these reasons, the search for rapid, reliable, and cost-effective strategies to monitor early changes in gastric ECL cell function and growth related to drug-induced hypergastrinaemia is justified.

The present study describes, for the first time, a correlation between serum gastrin and $\mathrm{CgA}$ levels during medium- and long-term acid suppressive therapy, suggesting that serum $\mathrm{CgA}$ might reflect functional and / or proliferative changes of the gastric ECL cells. This observation is consistent with our previous study involving healthy volunteers and short-term antisecretory therapy with $\mathrm{H}_{2} \mathrm{RAs}$ and PPIs, in which the increase in serum gastrin levels following different degrees of pharmacological acid inhibition was accompanied by similar increase in serum $\mathrm{CgA}$ levels ${ }^{43}$. These findings also confirm the results of Waldum et $a l^{42}$, who described augmented serum $\mathrm{CgA}$ values after short-term treatment with omeprazole and suggested its use as a test to evaluate ECL cell hyperplasia secondary to hypergastrinaemia, during long-term PPI therapy.

Based on a large sample of consecutive dyspeptic patients free of any conditions known to be associated with elevated serum gastrin and $\mathrm{CgA}$ levels, we found increased serum gastrin and $\mathrm{CgA}$ in patients on $\mathrm{PPI}$ therapy, but not in those on $\mathrm{H}_{2} \mathrm{RAs}$, or in nontreated dyspeptic controls with a similar distribution of age and gender. More than $38 \%$ of the patients receiving continuous acid inhibition with PPIs (15 of the 26 patients on long-term PPI and 3 of the 21 patients on medium-term PPI therapy) had serum $\mathrm{CgA}$ values above the normal range, whereas no 
patients on $\mathrm{H}_{2}$ RAs and only one control subject showed such increased levels.

This patient was a 63-year-old man, with a three year-history of persistent epigastric pain and nausea, without weight loss. His past history did not show any relevant events and an abdominal ultrasonography performed prior to endoscopy was normal. Gastroscopy showed no abnormalities. Fasting intragastric $\mathrm{pH}$ was 1.5 , serum gastrin and $\mathrm{CgA}$ were $11 \mathrm{ng} / \mathrm{l}$ and $8.2 \mathrm{nmol} / \mathrm{l}$, respectively, and H.pylori serology was negative. Routine biochemistry including liver and renal functional tests were normal. The family history revealed no findings suggestive of MEN I. As increased serum $\mathrm{CgA}$ levels are not totally specific to neuroendocrine tumours, a subclinical malignant process with neuroendocrine differentiation could account for the high circulating $\mathrm{CgA}$. However, neither before nor after the endoscopy was such condition detected.

In agreement with previous studies, fasting serum gastrin levels in the 47 patients on continuous PPI treatment were related to the degree and duration of gastric acid inhibition ${ }^{20,22,29,33,52,53}$. Moreover, we found that serum $\mathrm{CgA}$ described similar time-dependent changes. Linear regression analysis showed a slight but significant increase in serum $\mathrm{CgA}$ levels with the duration of continuous PPI therapy. In spite of similar distribution of the demographic data, patients on long-term ( 1 to 8 years) treatment with $\mathrm{PPI}$, had significantly higher serum $\mathrm{CgA}$ than those who received medium-term (6 weeks to 1 year) PPI therapy.

In a comprehensive study regarding the long-term effects of lansoprazole on serum gastrin, the progression of fundic gastritis and changes in fundic argyrophil cell morphology, Eissele et al. found a significant increase in fasting serum gastrin levels within the first 3 months of treatment, with no further elevation in the following five years of therapy ${ }^{29}$. Despite the plateau-phenomenon described for serum gastrin, argyrophil cell density showed a slight but steady increase during the five-year of follow-up investigation. In our study, even slightly elevated median serum gastrin levels $(127 \mathrm{ng} / \mathrm{ml})$ in patients on longterm PPI treatment corresponded to an increase in serum CgA levels. The duration of continuous stimulation rather than the magnitude of hypergastrinaemia seems to be responsible for the elevated serum $\mathrm{CgA}$ values in these patients. Whether increased serum $\mathrm{CgA}$ reflects only enhanced secretory function of the gastric ECL cells, as an early consequence of sustained hypergastrinaemia, or a late phenomenon, such as ECL cell proliferation, remains to be established.

The results of the current study support the role of H.pylori infection in the modulation of gastric ECL cell function and / or growth. Patients with positive H.pylori serology showed significantly higher serum gastrin and $\mathrm{CgA}$ levels compared to patients with negative H.pylori serology. 
The forthcoming hypothesis could be that serum CgA might provide additional information with regard to gastric mucosal endocrine and nonendocrine changes in H.pylori infected patients on antisecretory therapy.

We realise that the present study may suffer from several confounding factors. The cross-sectional design does not allow conclusions to be drawn concerning the precise time-course of serum $\mathrm{CgA}$ changes in patients on long-term PPI therapy. However, the significant increase in $\mathrm{CgA}$ with the longer period of acid inhibition is a genuine finding. An interesting question emerging in this context is whether persistent increase in serum $\mathrm{CgA}$ levels might interfere with gastric acid secretion. The functional role of circulating chromogranins in humans is poorly defined ${ }^{54}$. However, in experimental models, pancreastatin - the main $\mathrm{CgA}$-derived peptide - has been regarded as a potent inhibitor of gastric parietal cell secretion ${ }^{55}$. In view of this, one might speculate that elevated serum $\mathrm{CgA}$, subsequent to drug-induced hypergastrinaemia, may further upregulate gastrin secretion, thus explaining their parallel changes during long-term acid inhibition. On the other hand, reduction of the parietal cell secretion could further potentiate the pharmacologically-induced acid inhibition, in a selfperpetuating process.

In conclusion, we report significantly higher serum gastrin and $\mathrm{CgA}$ levels after long-term PPI therapy compared to $\mathrm{H}_{2} \mathrm{RA}$ therapy and nontreated dyspeptic controls. A combined effect of H.pylori infection and antisecretory therapy on gastric endocrine cells, reflected in increased serum gastrin and $\mathrm{CgA}$ levels, is also suggested. A possible relationship between elevated $\mathrm{CgA}$ in serum and the presence and severity of gastric mucosal endocrine proliferation remains to be further evaluated. 


\section{References}

1. Larsson $\mathrm{H}$, Carisson $\mathrm{E}$, Mattsson $\mathrm{H}$, et al. Plasma gastrin and enterochromaffin-like cell activation and proliferation. Studies with omeprazole and ranitidine in intact and antrectomized rats. Gastroenterology 1986;90:391-9.

2. Håkanson $R$, Böttcher $G$, Sundler $F$, et al. Activation and hyperplasia of gastrin and enterochromaffin-like cells in the stomach. Digestion 1986;35(Suppl 1):42-55.

3. Creutzfeldt $W$. The achlorhydria-carcinoid sequence: Role of gastrin. Digestion 1988; 39:61-79.

4. Håkanson R, Sundler $F$. Proposed mechanism of induction of gastric carcinoids: The gastrin hypothesis. Eur J Clin Invest 1990;20(S 1):65-71.

5. Håkanson $R$, Chen $D$, Tielemans $Y$, et al. ECL cells: biology and pathobiology. Digestion 1994;55(S 3):38-45.

6. Havu N. Enterochromaffin-like cell carcinoids of gastric mucosa in rats after lifelong inhibition of gastric secretion. Digestion 1986;35:42-55.

7. Havu N, Mattsson $\mathrm{H}$, Ekman L, et al. Enterochromaffin cell carcinoids in rat gastric mucosa following long-term administration of ranitidine. Digestion 1990;45:189-95.

8. Tielemans $Y$, Håkanson $R$, Sundler $F$, et al. Proliferation of enterochromaffin-like cells in omeprazole treated hypergastrinemic rats. Gastroenterology 1989;96:7239.

9. Solcia E, Rindi G, Havu N, et al. Qualitative studies of gastric endocrine cells in patients treated long-term with omeprazole. Scand J Gastroenterol. 1989;24(S 66):129-37.

10. Creutzfeldt $W$, Lamberts $R$, et al. Inter-relationship between serum gastrin levels, gastric mucosal histology and gastric endocrine cell growth. Digestion 1992;51(Suppl 1):76-81.

11. Solcia E, Capella C, Fiocca, et al. Gastric argyrophil carcinoidosis in patients with Zollinger-Ellison syndrome due to type I multiple endocrine neoplasia. A newly recognized association. Am J Surg Pathol 1990;14:503-13.

12. Lehy $T$, Cadiot $G$, Mignon $M$, et al. Influence of multiple endocrine neoplasia type-1 on gastric endocrine cells in patients with the Zollinger-Ellison syndrome. Gut 1992; 33:1275-9.

13. Lehy $\mathrm{T}$, Mignon $\mathrm{M}$, Cadiot $\mathrm{G}$, et al. Gastric endocrine cell behaviour in ZollingerEllison patients upon long-term potent antisecretory treatment. Gastroenterology 1989;96:1029-40.

14. Carney JA, Go VWL, Fairbanks, et al. The syndrome of gastric argyrophil carcinoid tumors and nonantral gastric atrophy. Ann Intern Med 1983;99:761-6.

15. Bordi $C$, Pilato F, Carfagna $G$, et al. Argyrophil cell hyperplasia of fundic mucosa in patients with chronic atrophic gastritis. Digestion 1986;35(S 1):130-43.

16. Borch $\mathrm{K}$, Renvall $\mathrm{H}$, Liedberg $\mathrm{G}$, et al. Gastric endocrine cell hyperplasia and carcinoid tumors in pernicious anemia. Gastroenterology 1985;88:638-48.

17. Solcia E, Fiocca R, Villani L, et al. Morphology and natural history of endocrine hyperplasias, precarcinoid lesions, and carcinoids arising in chronic atrophic gastritis. Scand J Gastroenterol 1991;26(S 180):146-59.

18. Chandrasekharappa S, Guru S, Manickam P, et al. Positional cloning of the gene for multiple endocrine neoplasia-type 1. Science 1997;Apr18;276(5311):404-7.

19. Solcia $E$, Rindi $G$, Fiocca $R$ et al. Distinct patterns of chronic gastritis associated with carcinoid, neuroendocrine carcinoma or ordinary cancer and their role in tumorigenesis. Yale J Biol Med 1992;65:793-804.

20. Bordi C, D'Adda $T$, Azzoni C, et al. Hypergastrinemia and Gastric Enterochromaffin-like Cells. Am J Surg Pathol 1995;19(S 1)8-19. 
21. Lamberts $R$, Creutzfeldt W, Stockmann $F$, et al. Long-term omeprazole treatment in man:effects on gastric endocrine cell populations. Digestion 1988;39:126-35.

22. Lamberts $R$, Creutzfeldt $W$, Strüber $H G$, et al. Long-term omeprazole therapy in peptic ulcer disease: gastrin, endocrine cell growth and gastritis. Gastroenterology 1993;104:1356-70.

23. Klinkenberg-Knol $E$, Festen $H$, Jansen J, et al. Long-term treatment with omeprazole for refractory reflux esophagitis: efficacy and safety. Annals of Internal Medicine 1994; vol 121,3:161-7.

24. Penston JG, Dixon JS, Selway SAM, et al. Gastric histology and plasma gastrin response to a meal in patients with duodenal ulcer disease after five years treatment with ranitidine. Aliment Pharmacol Ther 1990;4:381-92.

25. Kuipers EJ, Uyterlinde AM, Pena S, et al. Increase of Helicobacter-pyloriassociated corpus gastritis during acid-suppressive therapy: implications for longterm safety. Am J Gastroenterol 1995; vol 90,9:1401-6.

26. Kuipers EJ, Lundell L, Klinkenberg- Knol E, et al. Atrophic gastritis and Helicobacter pylori infection in patients with reflux esophagitis treated with omeprazole or fundoplication. N Engl J Med 1996;334:1018-22.

27. Solcia E, Villani L, Luinetti $O$, et al. Proton pump inhibitors, enterochromaffin-like cell growth and Helicobacter pylori gastritis. Aliment Pharmacol Ther $1993 ; 7(\mathrm{~S} .1): 25-28$.

28. El-Nujumi A, Williams C, McColl KEL, et al. Eradicating Helicobacter pylori reduces hypergastrinaemia during long-term omeprazole treatment. Gut 1998;42:159-65.

29. Eissele R, Brunner G, Simon B, et al. Gastric Mucosa During Treatment with Lansoprazole: Helicobacter pylori is a Risk Factor for Argyrophil Cell Hyperplasia. Gastroenterology 1997;112:707-17.

30. Waldum HL, Brenna E, Kleveland PM, et al. Review article: the use of gastric acidinhibitory drugs-physiological and pathophysiological considerations. Aliment Pharmacol Ther 1993;7:589-96.

31. Waldum HL, Brenna E, Kleveland PM, et al. Gastrin-physiological and pathophysiological role: clinical consequences. Dig Dis 1995;13:25-38.

32. Waldum $\mathrm{HL}$, Haugen $\mathrm{OA}$, Isaksen $\mathrm{R}$, et al. Enterochromaffin-like cells in the diffuse but not the intestinal type of gastric carcinomas. Scand J Gastroenterol 1991,26(Suppl 180),165-9.

33. Modlin I, Lawton G, Miu K, et al. Pathophysiology of the fundic enterochromaffinlike (ECL) cell and gastric carcinoid tumours. Ann R Coll Surg Engl 1996;78:133-8.

34. O'Connor D, Deftos LS. Secretion of chromogranin A by peptide producing endocrine cell. N Engl J Med 1986;314:1145-51.

35. Stridsberg $M$, Hellman $U$, Wilander $E$, et al. Fragments of chromogranin $A$ are present in the urine of patients with carcinoid tumours. Development of a specific radioimmunoassay for chromogranin $A$ and its fragments. $J$ Endocrinol 1993;139:329-37.

36. Stridsberg M, Öberg K, Li Q, et al. Measurement of chromogranin A, chromogranin $B$ (secretogranin I), chromogranin C (secretogranin II) and pancreastatin in plasma and urine of patients with carcinoid tumours. J Endocrinol 1995;144:49-59.

37. Fahrenkamp AG, Wibbeke $C$, Winde $G$, et al. Immunohistochemical distribution of chromogranins $A$ and $B$ and secretogranin $\|$ in neuroendocrine tumours of the gastrointestinal tract. Virchows Arch 1995;426:361-7.

38. Öberg K. Neuroendocrine gastrointestinal tumors-Review. Annals of Oncology 1996;7:453-63.

39. Stabile B, Howard T, Pasaro E, et al. Source of plasma chromogranin A elevation in gastrinoma patients. Arch Surg 1990;125:451-3.

40. Syversen $U$, Mignon M, Bonfils $S$, et al. Chromogranin A and pancreastatin-like immunoreactivity in serum of gastrinoma patients. Acta Oncologica 1993,vol.32, No.2,161-5. 
41. Borch $K$, Stridsberg $M$, Burman $P$, et al. Basal Chromogranin $A$ and Gastrin Concentrations in Circulation Correlate to Endocrine Cell Proliferation in Type-A Gastritis. Scand J Gastroenterol 1997;32:198-202.

42. Waldum HL, Arnestad JS, Brenna E, et al. Marked increase in gastric acid secretory capacity after omeprazole treatment. Gut 1996;39:649-653.

43. Houben $P$, Lundqvist $G$, Biemond $\mathrm{I}$, et al. Twenty-four-hour intragastric $\mathrm{pH}$, basal and meal-stimulated serum gastrin, and plasma chromogranin $A$ after short-term acid inhibition. Gastroenterology 1997;112; 4:A152.

44. Bonten M, Gaillard C, Stockbrügger RW, et al. Assessment of gastric acidity in intensive care patients: intermittent $\mathrm{pH}$ registration cannot replace continuous $\mathrm{pH}$ monitoring. Intensive Care Med.1996 Mar;22(3):220-5.

45. Jansen J, Lamers $C$. Effect of changes in serum calcium on secretin-stimulated serum gastrin in patients with Zollinger-Ellison syndrome. Gastroenterology 1982;83:173-8.

46. Mc Cloy RF, Arnold R, Bardhan KD, et al. Pathophysiological Effects of Long-term Acid Suppression in Man. Digestive Diseases and Sciences 1995 (February);40;2:96S-120S.

47. Leth $R$, Olbe $L$, Haglund $U$, et al. The pentagastrin-induced gastric acid response in humans. Scand J Gastroenterol 1988;23:224-48.

48. Waldum H, Sandvik A, Brenna $E$, et al. Gastrin-histamine sequence in the regulation of gastric acid secretion. Gut 1991;32:698-701.

49. Håkanson R, Sundler F. Do histamine-storing cells in the gastric mucosa mediate the acid-stimulating action of gastrin? Handbook Exp Pharm 1991;97:325-46.

50. Yogeshar D. Hyperplastic Proliferations of the ECL cells. Yale J Biol and Med 1992;65:805-25.

51. Driman DK, Wright C, Tougas G, et al. Omeprazole Produces Parietal Cell Hypertrophy and Hyperplasia in Humans. Digestive Diseases and Sciences 1996;41;10:2039-47.

52. Lind $\mathrm{T}$, Cederberg $\mathrm{C}$, Forssell $\mathrm{H}$, et al. Relationship between reduction of acid secretion and plasma gastrin concentration during omeprazole treatment. Scand $\mathrm{J}$ Gastroenterol 1988;23:1259-66.

53. Jansen J, Klinkenberg-Knol E, Meuwissen S, et al. Effects of Long-Term Treatment with Omeprazole on Serum Gastrin and Serum Group A and C Pepsinogens in Patients with Reflux Esophagitis. Gastroenterology 1990;99:621-8.

54. Hendy GN, Bevan S, Mattei MG, et al. Chromogranin A. Clin Invest Med 1995; 18:47-65.

55. Lewis JJ, Zdon MJ, Adrian TE, et al. Pancreastatin: a novel peptide inhibitor of parietal cell secretion. Surgery 1988;104:1031-6. 


\section{Chapter 4}

\section{Serum chromogranin A as a screening test for gastric enterochromaffin-like cell hyperplasia during acid- suppressive therapy}

S Sanduleanu, A de Bruïne, M Stridsberg,

D Jonkers, I Biemond, W Hameeteman,

G Lundqvist, RW Stockbrügger

Eur J Clin Invest (accepted) 


\section{Abstract}

\section{Background}

Serum chromogranin $A(\mathrm{CgA})$, a marker of neuroendocrine neoplasia, increases during profound gastric acid inhibition, possibly reflecting the trophic effect of gastrin on the enterochromaffin-like (ECL) cells.

\section{Aims}

This study investigated the clinical value of serum $\mathrm{CgA}$ as a screening test for gastric fundic enterochromaffin-like (ECL) cell hyperplasia during acid-suppressive therapy.

\section{Methods}

A consecutive series of 230 dyspeptic patients referred for upper gastrointestinal endoscopy was investigated in a cross-sectional design. They were 154 patients on continuous medium-term ( 6 weeks to one year) or long-term (longer than one year) acid inhibition with either proton pump inhibitors (PPIs, $n=117$ ) or histamine ${ }_{2}$-receptor antagonists $\left(\mathrm{H}_{2} \mathrm{RAs}, \mathrm{n}=37\right)$ for gastro-oesophageal reflux disease, and 76 non-treated subjects, with normal endoscopic findings (control group). Fasting blood samples were analysed for gastrin and $\mathrm{CgA}$. Gastric biopsy specimens (oxyntic mucosa) were examined for histological evaluation of gastritis (Sydney classification) and of ECL cell hyperplasia (Solcia classification).

\section{Results}

Serum CgA levels correlated positively with serum gastrin, following a quadratic function $(r=0.78, P<0.0001)$. Elevated serum $\mathrm{CgA}$ values during long-term acid inhibition correlated with the presence and severity of fundic ECL cell hyperplasia. Multivariate analysis identified hypergastrinaemia $(P<0.0001)$, duration of acid inhibition $(P<0.0001)$, H.pylori infection $(\mathrm{P}=0.008)$, $E C L$ cell hyperplasia $(P=0.012)$, and body gland atrophy $(\mathrm{P}=0.043)$ as independent predictors of elevated serum $\mathrm{CgA}$. In subjects on long-term acid inhibition ( $n=123$ ), serum $\mathrm{CgA}$ was equally sensitive but more specific than serum gastrin for the detection of ECL cell hyperplasia (sensitivity, $91.3 \%$ for both; specificity, $73 \%$ vs $43 \%, P<0.0001)$.

\section{Conclusions}

During long-term gastric acid inhibition, serum $\mathrm{CgA}$ levels reflect the presence and severity of fundic ECL cell hyperplasia. Serum $\mathrm{CgA}$ is therefore a useful screening test for gastric ECL cell proliferative changes within this context. 


\section{Introduction}

Gastrin release from the antral $G$ cells of the stomach is negatively regulated by luminal acid and therefore, hypergastrinaemia frequently occurs in association with acid-suppressive therapy ${ }^{1-3}$. Gastrin has a specific effect on the enterochromaffin-like (ECL) cells of the oxyntic mucosa, stimulating their function and proliferation ${ }^{4,5}$. Early toxicology studies demonstrated that rats treated long-term with histamine $2^{-}$ receptor antagonists $\left(\mathrm{H}_{2} \mathrm{RAs}\right)^{2,6}$ or with proton pump inhibitors (PPIs) ${ }^{2,7}$ develop gastric ECL cell hyperplasia, and subsequently carcinoid tumours.

In humans, this sequence of events has not sufficiently been established, possibly due to the limited follow-up duration of the available studies ${ }^{8,9}$. Most human gastric ECL cell carcinoids arise on a background of type A chronic atrophic gastritis or in patients with the Zollinger-Ellison syndrome associated with multiple endocrine neoplasia, indicating that hypergastrinaemia, immunological factors and genetic events may act in concert during gastric endocrine tumourigenesis ${ }^{10,11}$.

It should be pointed out, however, that in patients with pernicious anaemia, massive hypergastrinaemia, lasting more than one decade precedes the development of gastric carcinoids ${ }^{12,13}$. As endocrine tumour formation may be a very slow process it seems premature to discard the possibility of developing gastric ECL cell carcinoids in response to iatrogenic hypergastrinaemia.

In recent years, the combined effects of antisecretory therapy and Helicobacter pylori (H.pylori) infection on serum gastrin and gastric endocrine cells have elicited substantial clinical and research interest $^{14,15}$. Some studies have shown that, H.pylori infection - in patients treated with acid suppression - is a risk factor for the progression of corpus (atrophic) gastritis and the development of ECL cell hyperplasia ${ }^{15,16}$. Undoubtedly, the histological examination is essential for the accurate evaluation of such gastric mucosal changes. Neverthelss, it should be recalled that, the assessment of gastric endocrine proliferation in daily practice is hampered by the fact that such lesions are usually not endoscopically detectable and, thus, may be overlooked. Additionally, the co-existence of chronic atrophic gastritis with 'clustering' of the endocrine cells, or the presence of parietal cell hypertrophy/ hyperplasia secondary to hypergastrinaemia may bias the histological evaluation of ECL cell hyperplasia. To this end, efficient, non-invasive, and unexpensive screening methods to monitor the gastric endocrine lesions in this context are warranted. 
Chromogranin A (CgA) - a well-recognised marker of neuroendocrine neoplasia ${ }^{17,18}$ - may be released into the circulation from the ECL cell population of the stomach ${ }^{19-21}$. We and other investigators have reported elevated serum $\mathrm{CgA}$ in patients treated short-term ${ }^{22,23}$ and long-term ${ }^{24}$ with profound gastric acid inhibition. So far, it has not been elucidated whether the increased serum $\mathrm{CgA}$ levels under these circumstances only express an enhanced secretory function or reflect gastric ECL cell proliferation, secondary to drug-induced hypergastrinaemia.

The present study explored the clinico-pathological determinants of serum CgA levels in patients treated with acid suppression and in nontreated controls, with special reference to the role of the Helicobacter pylori infection. The issue addressed was whether serum $\mathrm{CgA}$ during long-term acid inhibition is a useful screening test for the detection of fundic ECL cell hyperplasia. The utility of serum gastrin, in this respect, was also assessed for comparison.

\section{Patients and methods}

\section{Study population}

A total of 230 consecutive dyspeptic patients referred for upper gastrointestinal endoscopy to an open-access unit were investigated, in a cross-sectional design. The study group consisted of 154 patients on continuous medium- or long-term acid-suppressive therapy for gastrooesophageal reflux disease (GORD), including erosive and non-erosive oesophagitis and/or Barrett's oesophagus. Continuous acid-suppressive therapy was defined as at least one daily dose of either omeprazole or ranitidine, taken either 6 weeks to one year (medium-term) or longer than one year (long-term), respectively. The control group consisted of 76 dyspeptic patients, with a similar distribution of age and gender, who did not receive any acid-suppressive medication or antacids before referral, and who had normal endoscopic findings. The following exclusion criteria were applied in all patients: (1) present or past history of peptic ulcer disease; (2) previous gastric surgery and/or vagotomy; (3) prior H.pylori eradication therapy; (4) treatment with antimicrobial agents, prokinetic drugs or nonsteroidal anti-inflammatory drugs within 30 days before endoscopy; (5) pancreas or other gastrointestinal pathology, (6) chronic liver or renal diseases; (7) malignancies or endocrine diseases. Subjects gave informed consent prior to inclusion, and the study was approved by the Ethical Review Board of the University Hospital Maastricht, The Netherlands. 


\section{Design of the study}

General clinical records and a structured interview concerning the history of reflux symptoms, type, daily dose, and duration of treatment with acid-suppressive medication, any comorbidity/ comedication, and family history of gastric cancer were obtained from all patients.

Endoscopy was performed after an overnight fast with standard gastroscopes (Pentax EG-2901). During endoscopy two antral biopsies ( $2 \mathrm{~cm}$ proximal to the pylorus) and four body mucosal biopsies $(10 \mathrm{~cm}$ below the gastro-oesophageal junction, along the greater curvature) were sampled for histological examination. Additional antral and/or body mucosal biopsies were taken for culture of H.pylori.

Fasting blood samples were drawn between 9.00 am and 11.00 am for the determination of serum $\mathrm{CgA}$ and serum gastrin levels.

\section{Laboratory assessments}

The serum $\mathrm{CgA}$ concentration was measured by radioimmunoassay, using polyclonal antibodies raised in rabbits against a fragment of chromogranin A (CgA 116-439) purified from the urine of a patient with a carcinoid tumour ${ }^{18,25}$. These antibodies bind to both intact and partly degraded $\mathrm{CgA}$. As previously described, this method measures $\mathrm{CgA}$ fragments released into the circulation from the ECL cell population of the stomach ${ }^{21,26}$. This assay has a high precision with intra- and interassay coefficients of variation of less than $6.4 \%{ }^{25}$. The serum gastrin concentration was assessed by radioimmunoassay, using antibodies raised in rabbits against synthetic unsulphated human gastrin 2-17 covalently coupled to bovine serum albumin, as described elsewhere ${ }^{27}$. These antibodies bind to all major forms of circulating gastrin with an almost equal potency. The intra- and inter-assay coefficients of variation with this method are less than $10 \%$. For fasting serum $\mathrm{CgA}$, the upper limit of the normal range was $4 \mathrm{nmol} / \mathrm{L}^{18}$ and for fasting serum gastrin was $85 \mathrm{ng} / \mathrm{L}^{27}$.

\section{Histopathology}

Biopsy specimens for histopathological examination were formalin fixed and paraffin embedded. Serial sections $(4 \mu \mathrm{m})$ were cut and stained with haematoxylin-eosin for general histological analysis. All biopsy specimens were reviewed by one experienced gastroenterological pathologist (A.B.), without knowledge of the patients' clinical and serological data. Discordant results, although rare, were discussed with a second pathologist and a joint diagnosis was made.

The histomorphologic status of the gastric body mucosa was assessed according to the Sydney classification ${ }^{28}$. The following parameters were evaluated: active inflammation (i.e., neutrophilic cell 
infiltration); chronic inflammation (i.e., mononuclear cell infiltration), and gland atrophy (i.e., loss of appropriate glands). All items were graded from 0 to 3 (0, absent; 1 , mild; 2 , moderate; 3 , severe changes). For analysis of each parameter, the highest grade among the biopsies of the respective gastric area was considered.

In addition, specimens of body mucosa were immunostained for endocrine cells using a monoclonal antibody against human chromogranin A $(1: 50000)$ as primary antibody (LK2H10, Hybritech, San Diego, CA, USA) ${ }^{29}$. This technique stains several types of gastric endocrine cells, such as ECL cells, enterochromaffin cells and A-like (or $X$ ) cells, but not the somatostatin-producing $D$ cells. Furthermore, it is known that the ECL cells constitute the predominant endocrine cell type of the gastric oxyntic mucosa (30-50\% in humans) and the only one which develop hyperplasia in response to iatrogenic hypergastrinaemia ${ }^{3,30}$. Therefore, chromogranin A immunostaining ranks as a reliable method to evaluate ECL cell hyperplasia.

The status of the ECL cell population of the corpus mucosa was evaluated according to the Solcia classification ${ }^{31}$. Based on a semiquantitative histological approach, endocrine hyperplastic lesions have been defined and graded, as follows: 0 , absent; 1 , diffuse hyperplasia (increase of the number of endocrine cells with coalescence of a few cells); 2, linear hyperplasia (occurrence of at least two linear sequences of five or more endocrine cells per linear millimeter of mucosa); and 3, micronodular hyperplasia (occurrence of at least 1-2 clusters composed of five or more endocrine cells per linear millimeter of mucosa).

\section{Helicobacter pylori}

Determination of current H.pylori status was performed in both antral and corpus mucosa by modified Giemsa stain, immunohistochemistry (IMM), and culture. For the IMM, a purified polyclonal antiserum (DAKO B471, ITK diagnostics BV, Uithoorn, The Netherlands) in a dilution of $1: 100$ was used $^{32}$. Culture of gastric biopsies was performed on selective Campylobacter plates, under microaerophilic conditions. H.pylori was considered present if histopathology and/or culture were positive.

\section{Statistical evaluation}

Differences in dichotomous variables were evaluated using the chisquare test or Fisher's exact test, depending on the number of patients. As the continuous variables were not normally distributed, values were expressed as medians, with interquartile ranges, and non-parametric tests were used (Kruskal-Wallis test for multiple comparisons and Mann-Whitney $U$ test for two group comparisons). Correlations were 
performed with the Spearman rank test. Multivariate linear regression analyses with the logarithm of serum $\mathrm{CgA}$ as the dependent variable were performed to identify independent predictors of serum $\mathrm{CgA}$ levels among the study population. Two-sided $P$-values $<0.05$ were assumed to indicate statistical significance.

\section{Results}

\section{Study population}

The study population comprised 230 patients with complete clinical, serological and histological data. Table 4.1 summarises the demographic and relevant clinical characteristics of the patients, classified according to the type of acid-suppressive therapy they were receiving. The age distribution and the sex ratios were not statistically different among the three patient groups.

Table 4.1. Demographic, clinical, and endoscopic characteristics of the 230 patients

\begin{tabular}{|c|c|c|c|}
\hline Characteristics & Controls & H2RA group & PPI group \\
\hline Number of patients & 76 & 37 & 117 \\
\hline Age (years) ${ }^{\star}$ & $51.5(19-79)$ & $52(20-73)$ & $51(21-78)$ \\
\hline Male:female ratio & $1.05: 1$ & $0.95: 1$ & $1.3: 1$ \\
\hline Duration of acid inhibition (months) ${ }^{*}$ & - & $32(1.5-216)$ & $29(1.5-168)$ \\
\hline $\begin{array}{l}\text { Dose of medication (mg daily) } \\
\text { Endoscopic findings }(\%) \\
\text { - GORD }\end{array}$ & - & $300(150-450) \dagger$ & $40(20-80) \ddagger$ \\
\hline non-erosive & - & 62.1 & 53.8 \\
\hline erosive & - & 32.4 & 16.3 \\
\hline - Barrett's oesophagus & - & 5.5 & 29.9 \\
\hline - normal findings & 100 & - & - \\
\hline
\end{tabular}

*Data are expressed as median (range). Daily doses of franitidine and fomeprazole.

\section{Serum gastrin and chromogranin $A$ in relation to acid inhibition}

Serum gastrin levels were higher in the PPI-treated group compared to the $\mathrm{H}_{2} \mathrm{RA}$-treated group and controls $(107$ [12-800] ng/L vs 51 [8-150] $\mathrm{ng} / \mathrm{L}$ and 107 [12-800] $\mathrm{ng} / \mathrm{L}$ vs 30 [5-194] $\mathrm{ng} / \mathrm{L}, \mathrm{P}<0.0001$ for both). Similarly, serum $\mathrm{CgA}$ levels were higher in the PPI group than in the $\mathrm{H}_{2} \mathrm{RA}$ group and in controls (3.7 [0.7-26.1] nmol/L vs 2.0 [1.5-5.6] $\mathrm{nmol} / \mathrm{L}$ and 3.7 [0.7-26.1] nmol/L vs 1.9 [1.2-3.9] nmol/L, $\mathrm{P}<0.0001$ for both). No significant differences with regard to serum gastrin and serum $\mathrm{CgA}$ values were found between the $\mathrm{H}_{2} \mathrm{RA}$ group and controls. Serum gastrin levels exceeded the upper limit of normal in $78(66.7 \%)$ patients on PPIs, in $9(24.3 \%)$ patients on $\mathrm{H}_{2} \mathrm{RAs}$, and in $8(10.5 \%)$ controls, 
while the corresponding figures for serum CgA were $51(43.6 \%), 3$ $(8.1 \%)$, and $0(0 \%)$ of the subjects, respectively.

In the total study population fasting serum gastrin correlated positively with fasting serum $\mathrm{CgA}$ levels $(r=0.78, P<0.0001)$ (Figure 4.1). This correlation could be fitted best by a quadratic function: $y=$ $0.159 x^{2}-0.817 x+1.585$, in which $y=\log (\mathrm{CgA})$ and $x=\log$ (gastrin).

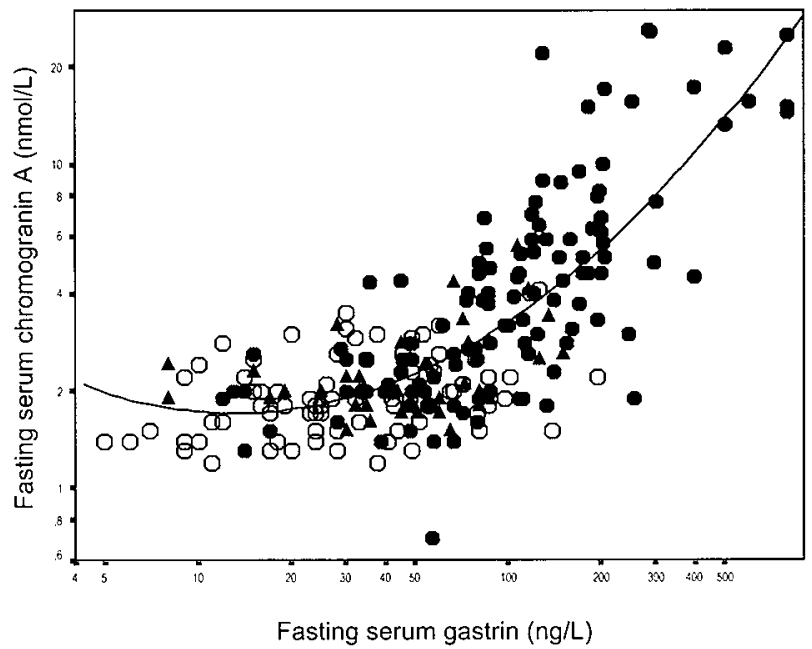

Figure 4.1 The correlation between fasting serum gastrin and fasting serum $\mathrm{CgA}$ levels $(r=0.78 ; P<0.0001 ; n=230)$ was fitted best by a quadratic function: $y=0.159$ $x^{2}-0.817 x+1.585$, in which $y=\log (\mathrm{CgA})$ and $x=\log$ (gastrin). The different symbols represent the three patient groups: controls (O), $\mathrm{H}_{2} \mathrm{RA}$ group (A), and PPI group (-). The individual data are plotted on a logarithmic scale to accomodate for extreme values.

\section{Serum gastrin, chromogranin A and H.pylori infection}

H.pylori infection was detected in 32 out of $76(42.2 \%)$ controls, in 15 out of $37(40.5 \%)$ patients in the $\mathrm{H}_{2} \mathrm{RA}$ group, and in 43 out of 117 $(36.7 \%)$ patients in the PPI group.

As shown in Figures 4.2a and 4.2b, H.pylori-positive subjects had higher serum gastrin and higher serum CgA levels than the $H$. pylorinegative subjects, across all three patient groups. The highest serum gastrin and $\mathrm{CgA}$ values were observed in the H.pylori-positive patients treated with PPIs. 
(a)

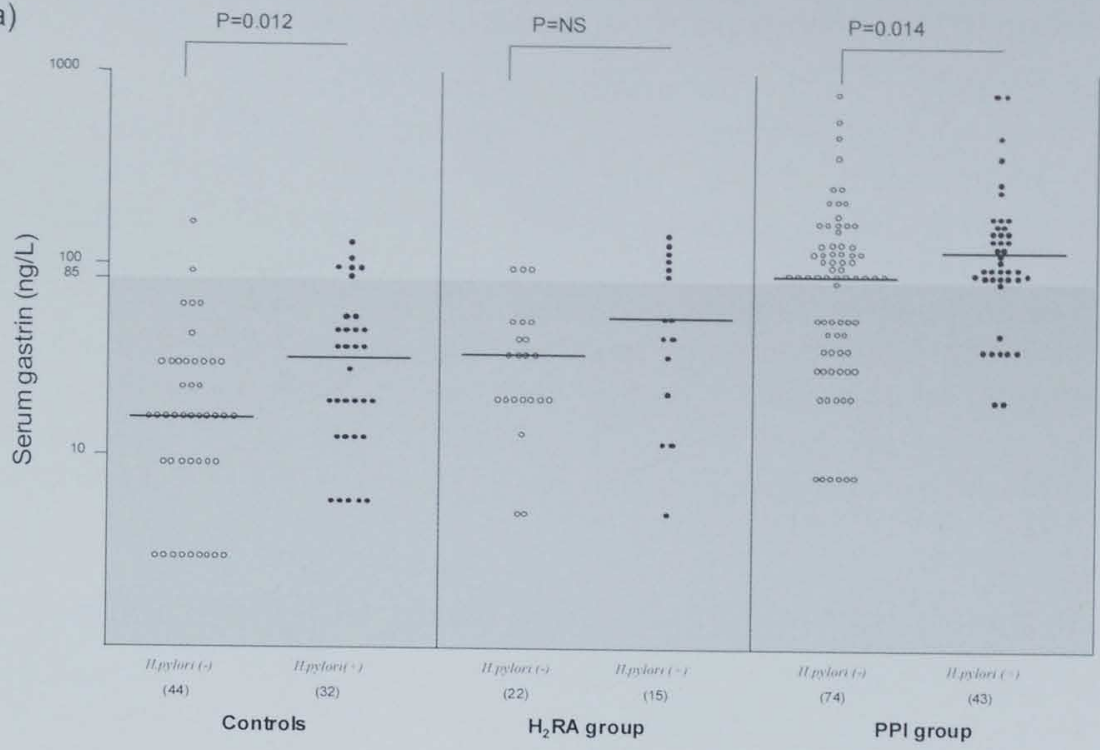

(b)

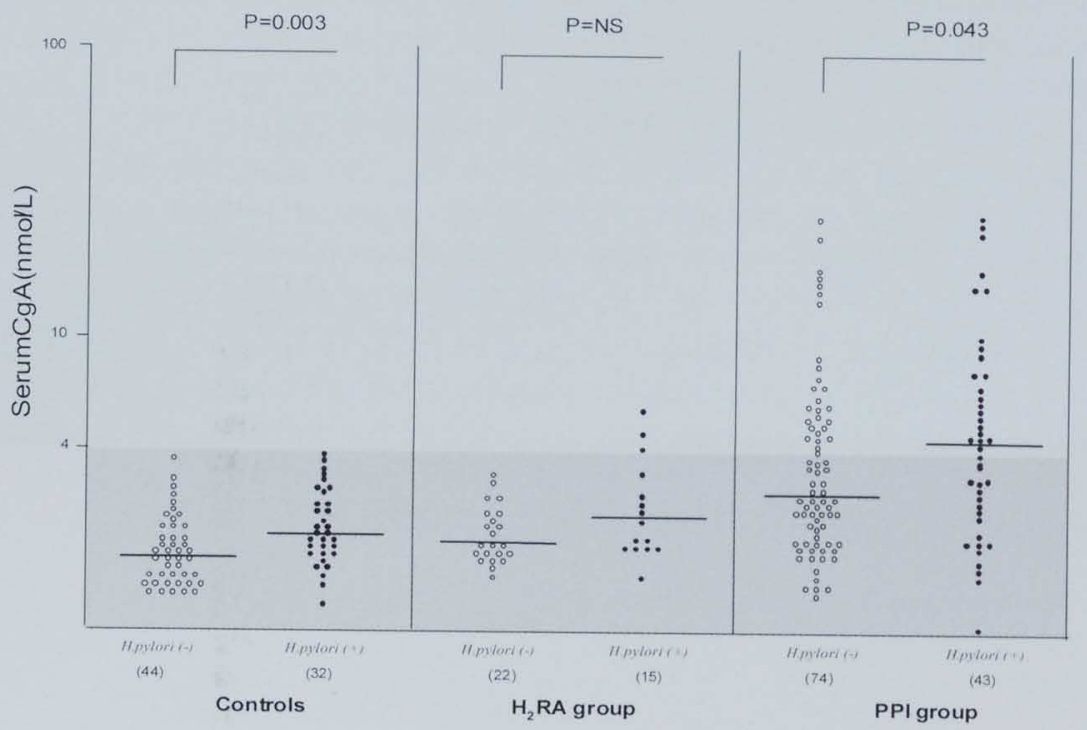

Figure 4.2 Fasting serum gastrin (a) and fasting serum CgA (b) levels in H.pylorinegative $(\mathrm{O})$ and H.pylori-positive (O) subjects. The shadded area indicates the normal range. The horizontal bars indicate median values. The individual data are plotted on a logarithmic scale to accomodate for extreme values. Numbers of subjects in parentheses. 


\section{Serum gastrin, chromogranin $\mathrm{A}$ and body gastritis}

Table 4.2 describes the parameters of body gastritis in all patients. As expected, H.pylori-positive subjects yielded a higher prevalence of active inflammation, chronic inflammation and body gland atrophy than the H.pylori-negative subjects, across all three patient groups. The highest prevalence and severity of body gland atrophy were observed in the H.pylori-positive patients treated with PPIs.

In the study population, patients with body gland atrophy had significantly higher serum gastrin and serum $\mathrm{CgA}$ levels than those without it (serum gastrin: 114.5 [25-800] $\mathrm{ng} / \mathrm{L}$ vs 58 [5-253] $\mathrm{ng} / \mathrm{L}$, $\mathrm{P}=0.008$ and serum $\mathrm{CgA}: 3.6[1.1-26.1] \mathrm{nmol} / \mathrm{L}$ vs $2.3[1.2-14.4] \mathrm{nmol} / \mathrm{L}$, $P=0.004)$.

\section{Serum gastrin, chromogranin A and fundic ECL cell hyperplasia}

As shown in Table 4.2, the prevalence of ECL cell hyperplasia was higher in the $\mathrm{PPI}$ group than in the $\mathrm{H}_{2} \mathrm{RA}$ group $(18.8 \%$ vs $5.4 \%$, $\mathrm{P}=0.05)$ and in the controls $(18.8 \%$ vs $3.9 \%, \mathrm{P}<0.004)$, whereas no significant difference in this respect was found between patients on $\mathrm{H}_{2}$ RAs and controls. Additionally, in the entire series, H.pylori-positive subjects had a higher prevalence of ECL cell hyperplasia than the H.pylori-negative subjects $(23.4 \%$ vs $4.3 \%, \mathrm{P}<0.0001)$.

As illustrated in Figures $4.3 \mathrm{a}$ and $4.3 \mathrm{~b}$, the patients with ECL cell hyperplasia - either H.pylori-negative or -positive - had higher serum gastrin and higher serum $\mathrm{CgA}$ levels than those without ECL cell hyperplasia. Moreover, serum gastrin and serum $\mathrm{CgA}$ correlated positively with the histological degree of ECL cell hyperplasia (Figures 4.4a and $4.4 b$ ). The group of H.pylori-positive patients treated with PPIs had the highest prevalence and severity of fundic ECL cell hyperplasia (Table 4.2). None of the specimens investigated showed either adenomatoid, dysplastic lesions, or carcinoids. 


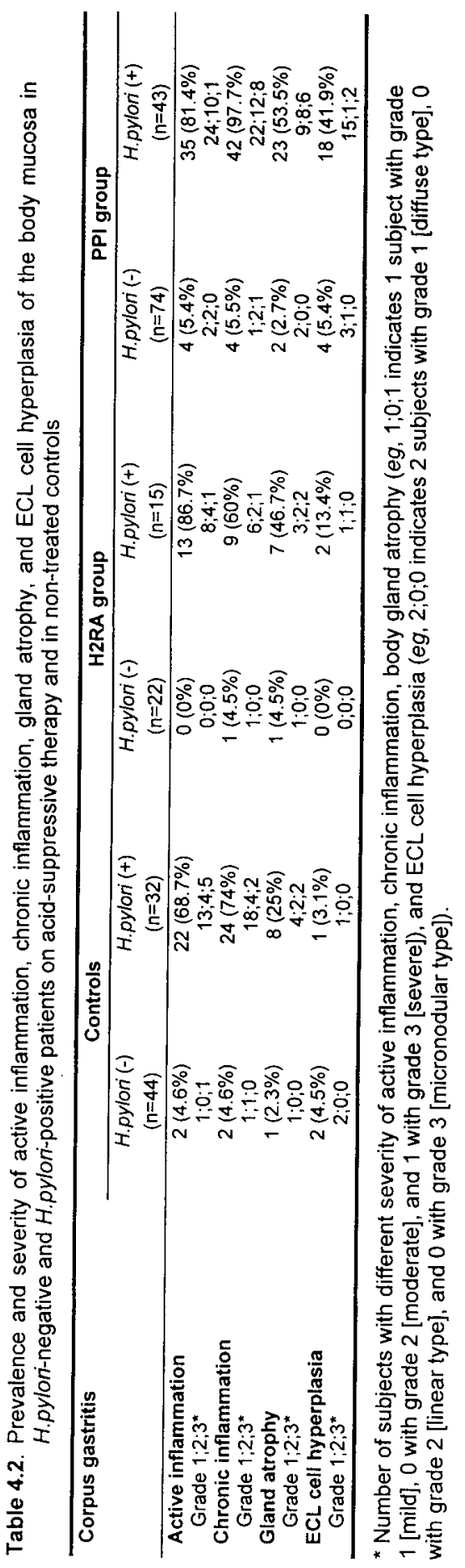


(a)

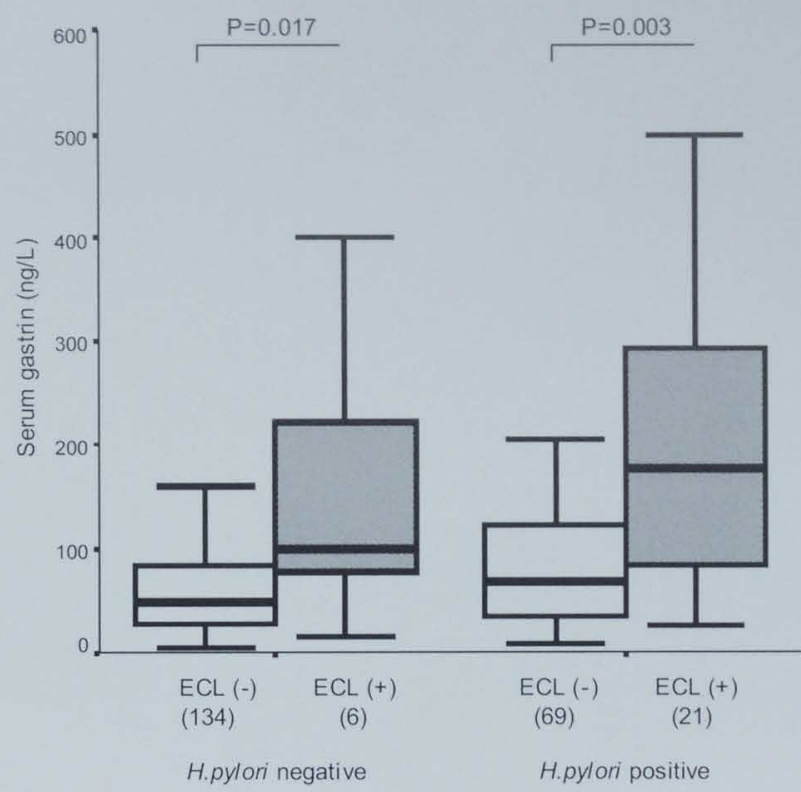

(b)

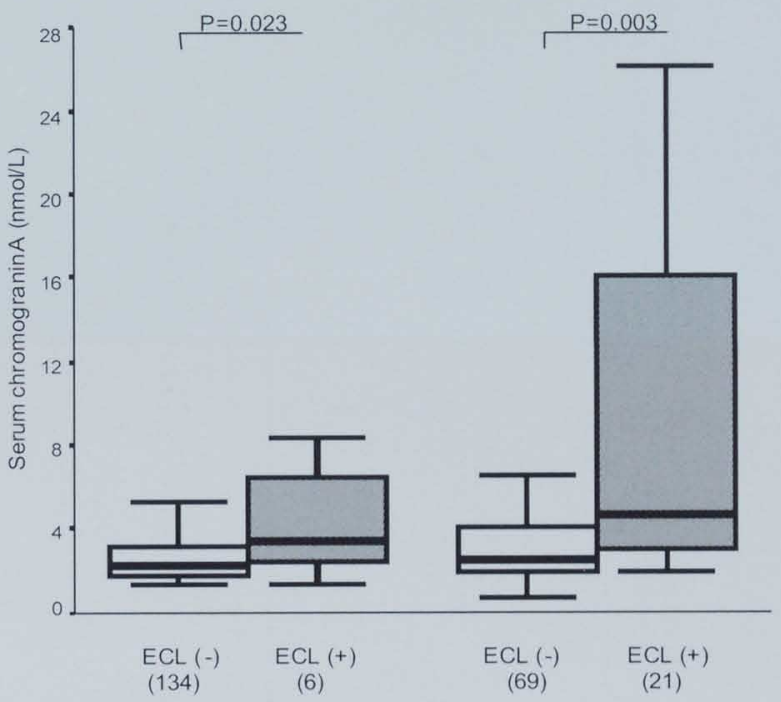

H.pylori negative H.pylori positive

Figure 4.3 Fasting serum gastrin (a) and fasting serum $\mathrm{CgA}$ (b) levels in relation to ECL cell hyperplasia and H.pylori infection. The $50^{\text {th }}$ percentile (median) is indicated with a line in the box, the end of the box indicates the $25^{\text {th }}$ and $75^{\text {th }}$ percentile, and the $10^{\text {th }}$ and $90^{\text {th }}$ percentile are indicated with error bars. Numbers of subjects in parentheses. 
(a)

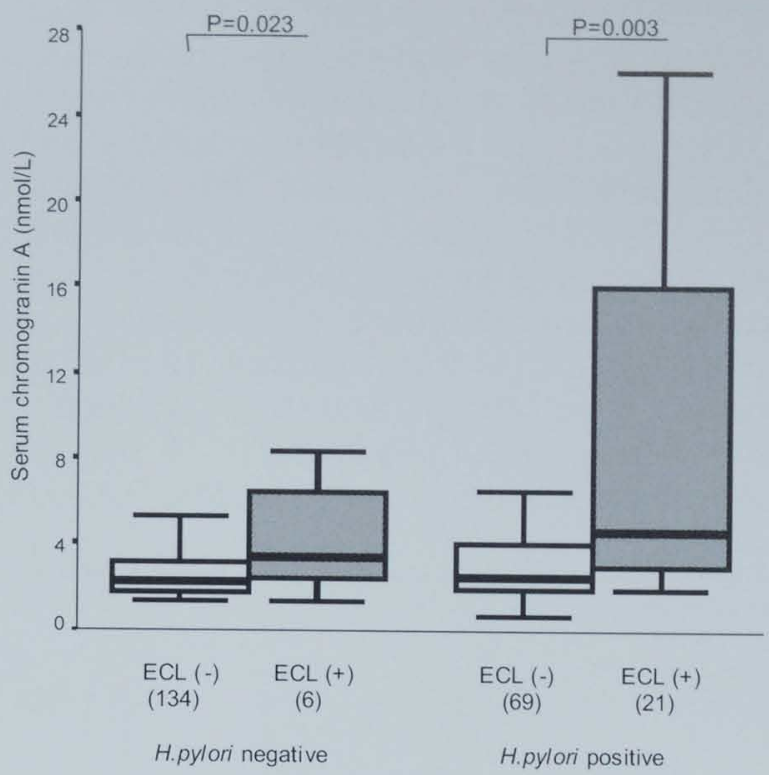

(b)

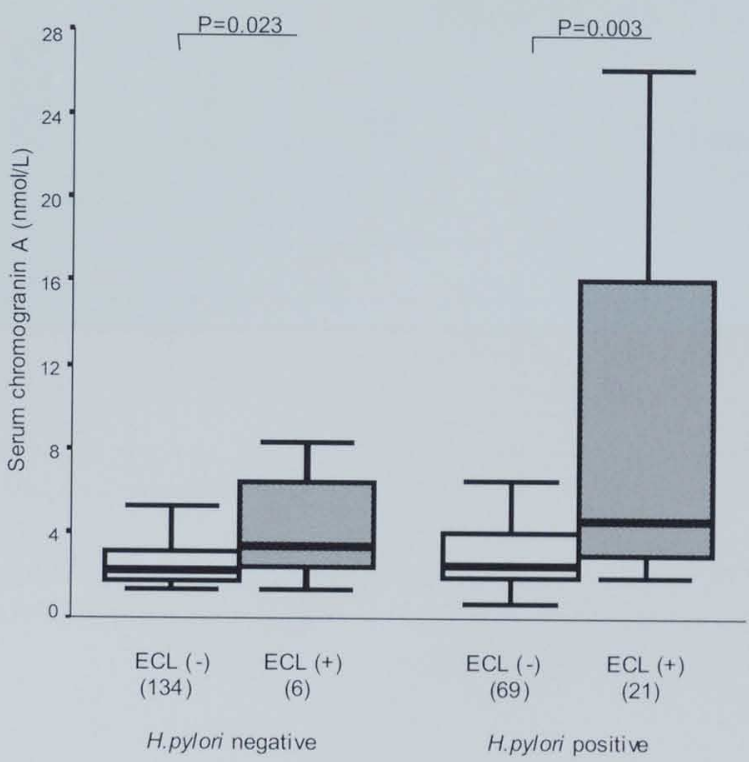

Figure 4.4 Fasting serum gastrin (a) and fasting serum CgA (b) levels in relation to the histological degree of ECL cell hyperplasia. The $50^{\text {th }}$ percentile (median) is indicated with a line in the box, the end of the box indicates the $25^{\text {th }}$ and $75^{\text {th }}$ percentile, and the $10^{\text {th }}$ and $90^{\text {th }}$ percentile are indicated with error bars. Numbers of subjects in parentheses. 
Figure 4.5 shows the relationship between serum gastrin, serum $\mathrm{CgA}$, gastric fundic ECL cell hyperplasia, and the duration of acidsuppressive therapy. The total study population was subdivided into six subgroups, according to the duration of treatment they had undergone. No significant differences with regard to age, gender and prevalence of H.pylori infection were observed among the six patient subgroups ( $P=0.76, P=0.95, P=0.74$, respectively). High serum gastrin levels (>85ng/L) were present in a large proportion of patients, with a nearly stable rate after one year of treatment. However, the frequency of elevated serum CgA levels ( $>4 \mathrm{nmol} / \mathrm{L}$ ) increased after acid suppression longer than one year, and was paralleled by a gradual increase in the prevalence of ECL cell hyperplasia $(3.2 \%$ of patients treated $<12$ months $v s 33.4 \%$ of patients treated $>48$ months, $P=0.003$ ).

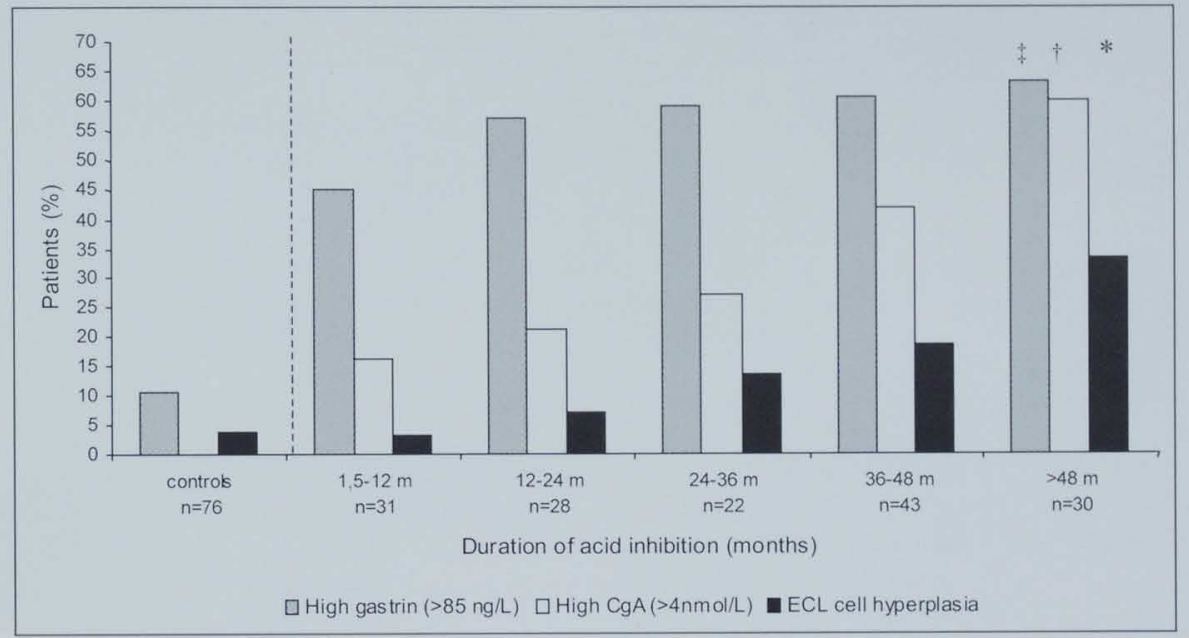

${ }^{*} P<0.003,+P<0.001$ and $\ddagger P=0.15$ vs patients treated $<12$ months

Figure 4.5. Relationship between serum gastrin, serum CgA levels, ECL cell hyperplasia, and the duration of acid-suppressive therapy.

Table 4.3 shows the clinico-pathological characteristics of the five patients with more severe (linear or micronodular) pattern of ECL cell hyperplasia. 


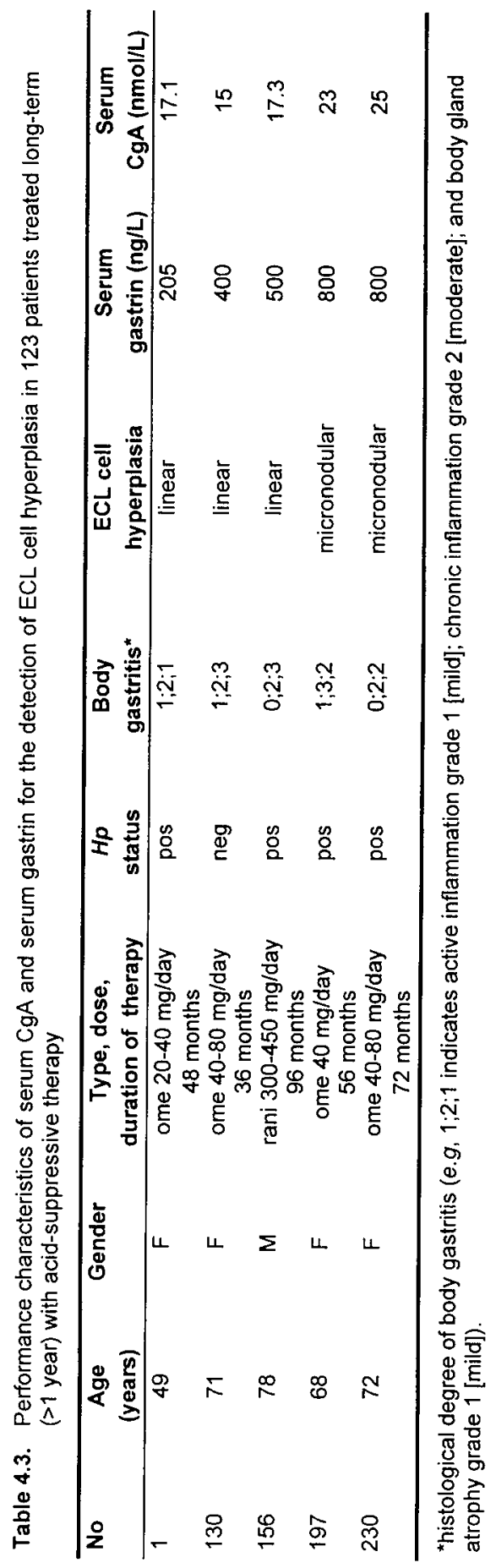




\section{Multivariate analysis}

Multiple stepwise linear regression analysis was performed to identify determinants of serum $\mathrm{CgA}$ levels in the study population. Hypergastrinaemia $(P<0.0001)$, duration of acid-suppressive therapy in years $(P<0.0001)$, infection with H.pylori $(P=0.008)$, fundic $E C L$ cell hyperplasia $(P=0.012)$ and body gland atrophy $(P=0.043)$ were independent predictors of elevated serum $\mathrm{CgA}$ values. Age and gender did not significantly influence serum $\mathrm{CgA}$ levels. No interactions between variables were found.

\section{Clinical utility of serum chromogranin A in screening for ECL cell hyperplasia}

As the prevalence of ECL cell hyperplasia progressively increased in patients treated with acid suppression longer than one year $(n=123)$, we further examined the clinical utility of serum $\mathrm{CgA}$ as a screening test for ECL cell hyperplasia in these patients, by comparing it to serum gastrin in this respect. Among these 123 patients, elevated serum gastrin (>85 $\mathrm{ng} / \mathrm{L})$ were observed in $74(60 \%)$ cases, elevated serum $\mathrm{CgA}$ $(>4 \mathrm{nmol} / \mathrm{L})$ in $48(39 \%)$ cases, and $23(18.7 \%)$ cases displayed histological signs of ECL cell hyperplasia. Twenty-one of the 74 subjects with elevated serum gastrin displayed $E C L$ cell hyperplasia. Likewise, 21 of the 48 subjects with elevated serum CgA displayed ECL cell hyperplasia. The test performance characteristics for serum gastrin and serum $\mathrm{CgA}$ in the detection of ECL cell hyperplasia are detailed in Table 4.4. The sensitivity of serum CgA was high and equal to that of serum gastrin $(91.3 \%)$. However, serum $\mathrm{CgA}$ had a significantly higher specificity compared to serum gastrin $(73 \%$ vs $47 \%, P<0.0001)$. Both parameters showed good negative predictive values for ECL cell hyperplasia (serum CgA: $97.3 \%$ and serum gastrin: 95.9\%, respectively), but limited positive predictive values (serum $\mathrm{CgA}: 43.8 \%$ and serum gastrin: $28.4 \%$, respectively).

Table 4.4. Performance characteristics of serum $\mathrm{CgA}$ and serum gastrin in the detection of ECL cell hyperplasia in 123 patients treated long-term (>1 year) with acid-suppressive therapy.

\begin{tabular}{lcc}
\hline & $\begin{array}{c}\text { Serum } \\
\text { chromogranin A* }\end{array}$ & Serum gastrin* $^{*}$ \\
\hline Sensitivity (\%) & 91 & 91 \\
Specificity (\%) & 73 & 47 \\
Positive predictive value (\%) & 44 & 28 \\
Negative predictive value (\%) & 97 & 96 \\
\hline
\end{tabular}

*Normal range for serum $\mathrm{CgA}$ was defined as $<4 \mathrm{nmol} / \mathrm{L}$ and for serum gastrin as $<85 \mathrm{ng} / \mathrm{L}$. 


\section{Discussion}

The current study confirmed that gastric fundic ECL cell hyperplasia develops during long-term profound acid suppression - particularly in H.pylori-positive patients - and has shown that this process is well reflected by increased serum $\mathrm{CgA}$ levels. This holds true for serum gastrin regarding test sensitivity. However, serum $\mathrm{CgA}$ has a better specificity than serum gastrin, being a more reliable test for the detection of ECL cell hyperplasia in patients treated long-term with acid suppression. Multivariate analysis identified hypergastrinaemia, the duration of acid-suppressive therapy, H.pylori infection, fundic ECL cell hyperplasia and body gland atrophy as independent predictors of increased serum CgA values. As such, several biological hypotheses may explain the observed elevations in serum $\mathrm{CgA}$ during treatment with antisecretory medication.

Acid-related mechanisms play an essential role in this multifactorial process. In a recent study concerning the long-term effects of the proton pump inhibitor lansoprazole on serum gastrin and gastric endocrine mucosa, Eissele et al. found a significant increase in fasting serum gastrin levels within the first 3 months of treatment, without further elevation in the following 5 years of therapy ${ }^{15}$. This moderate and selflimited hypergastrinaemia was, however, accompanied by a steady increase in the ECL cell density during the 5-year follow-up. These findings in humans reproduce previous reports in rats ${ }^{33}$, emphasizing the critical role of the duration of stimulation in the proliferation of ECL cells. Our results further substantiate and extend these data by demonstrating the additional value of serum $\mathrm{CgA}$ for the assessment of the gastric ECL cell status. As shown in Figure 4.1, at a moderate elevation in serum gastrin level - compatible with the known plateauphenomenon - serum CgA levels increase, following a quadratic function. Interestingly, Figure 4.5 indicates that in contrast to serum gastrin concentrations - which tend to level off - serum CgA levels gradually rise and are accompanied by an increasing prevalence of ECL cell hyperplasia, affecting one third of the patients after four years of antisecretory treatment. In view of these observations, we consider that increased serum $\mathrm{CgA}$ during acid-suppressive therapy initially might reflect a hypersecretory state of the ECL cells, as an early response to sustained hypergastrinaemia, but in patients treated long-term with acid suppression such increase is more likely to be the result of ECL cell hyperplasia. In line with this, previous data in rats also indicated that, as opposed to low-molecular fragments of $\mathrm{CgA}$ (e.g., pancreastatin), which are more influenced by the ECL cell hypersecretory state, the highmolecular forms of $\mathrm{CgA}$ reflect more accurately the ECL cell mass ${ }^{34,35}$. 
In this study, elevated serum gastrin and serum $\mathrm{CgA}$, as well as fundic ECL cell hyperplasia were mainly observed in patients treated with PPIs. However, in contrast to earlier reports, that precluded the development of ECL cell proliferative lesions following treatment with $\mathrm{H}_{2} \mathrm{RAs}^{36}$, we found elevated serum $\mathrm{CgA}$ and $\mathrm{ECL}$ cell hyperplasia also in a small proportion of patients treated with $\mathrm{H}_{2}$ RAs. These results support the contention that fundic ECL cell hyperplasia may develop during long-term acid inhibition with any type of effective antisecretory drug.

This is, to our knowledge, the first study to provide insight into the relationship between H.pylori infection, gastric mucosal morphology, and serum $\mathrm{CgA}$ levels during antisecretory therapy. We report higher fasting serum gastrin and serum $\mathrm{CgA}$ levels in the H.pylori-positive compared to the H.pylori-negative subjects. Additionally, we suggest that the markedly increased serum gastrin and $\mathrm{CgA}$ concentrations in H.pylori-positive patients treated with PPIs reflected more advanced body gland atrophy and proliferation of the ECL cells.

Of particular note was the observation that, the magnitude of serum $\mathrm{CgA}$ levels correlated positively with the histological degree of ECL cell hyperplasia. In fact, the five patients with either linear or micronodular pattern of ECL cell hyperplasia had serum CgA levels on average fivefold higher than in those with a diffuse pattern. In a study by Borch et al. on patients with type A chronic atrophic gastritis, $\mathrm{CgA}$ concentrations correlated to endocrine cell densities in the fundic mucosa ${ }^{21}$. The correlation between serum $\mathrm{CgA}$ and the histological degree of ECL cell hyperplasia found in our series is in line with such data. The number of patients with an advanced type of endocrine cell growth was, however, small; therefore, this relation needs to be confirmed in further studies.

The results of the current study shed some light on a controversial clinical issue: Should patients on long-term acid-suppressive therapy be routinely screened for the early detection of gastric ECL cell hyperplasia, in order to prevent carcinoid tumour formation? Although one single case report ${ }^{9}$ gives some warning, 10 to 15 years of worldwide experience with potent inhibitors of gastric acid secretion does not justify major concern. The question remains, however, still open for the large number of patients considered for lifelong acid suppression, because of gastro-oesophageal reflux diseases that are not referred to surgery. In these patients, it seems advisable to monitor serum CgA levels instead of the less specific serum gastrin. At markedly increased $\mathrm{CgA}$ values indication should be given for endoscopic and histological examination of the gastric mucosa.

A few comments have to be made regarding methodological aspects of this study: First, we investigated a large series of consecutive patients, recruited from a primary care population; this confers 
generality to the results presented and conclusions. Second, the study was cross-sectional in design; however, the reliable patient histories concerning the length of antisecretory therapy and the comparison with non-treated controls with similar demographic features, enabled us to estimate the role of the time factor in the development of ECL cell hyperplasia. Third, all subjects were free of any conditions known to interfere with serum $\mathrm{CgA}$ concentrations ${ }^{21,37,38}$, thereby supporting the notion that the elevated $\mathrm{CgA}$ values during acid-suppressive therapy accurately reflect the stimulation of the gastric ECL cells. Forth, in the present study fasting levels of serum gastrin and serum CgA were measured. The determination of non-fasting values was beyond our scope, but it is also unlikely that meal-stimulated values of serum $\mathrm{CgA}$ would provide any additional information to fasting $\mathrm{CgA}^{39}$. It can be expected that at a maximal gastrin stimulation, serum $\mathrm{CgA}$ may level off. Consequently, any additional increase in serum gastrin, due to meal-stimulation, would have relatively little effect on serum $\mathrm{CgA}$. This hypothesis is in line with experimental data indicating that pancreastatin - the main CgA-derived peptide - exerts an inhibitory effect on gastric parietal cells ${ }^{40}$ and thereby, may further up-regulate gastrin secretion in a self-perpetuating process.

In conclusion, we have shown that, serum $\mathrm{CgA}$ during long-term acidsuppressive therapy, is an equally sensitive and more specific, noninvasive marker of ECL cell hyperplasia than serum gastrin. In view of the potential negative consequences of iatrogenic hypergastrinaemia on the gastric endocrine mucosa, it seems prudent to monitor serum $\mathrm{CgA}$ levels in patients treated long-term with profound acid suppression, as they reflect the presence and severity of ECL cell hyperplasia. 


\section{References}

1. Stockbrügger $R$, Larsson $L$, Lundqvist $G$, Angervall $L$. Antral gastrin cells and serum gastrin in achlorhydria. Scand J Gastroenterol 1977;12:209-13

2. Larsson $H$, Carlsson $E$, Mattson $H$, Lundell L, Sundler $F$, Sundell G, et al. Plasma gastrin and gastric enterochromaffin-like cell activation and proliferation. Studies with omeprazole and ranitidine in intact and antrectomized rats. Gastroenterology 1986;90:391-99.

3. Håkanson R, Böttcher G, Sundler F, Vallgren S. Activation and hyperplasia of gastrin and enterochromaffin-like cells in the stomach. Digestion 1986;35(suppl. 1):42-55.

4. Creutzfeldt $W$. The achlorhydria-carcinoid sequence. Role of Gastrin. Digestion 1988;39:61-79.

5. Håkanson R, Sundler F. Proposed mechanism of induction of gastric carcinoids: The gastrin hypothesis. Eur J Clin Invest 1990;20(Suppl 1):65-71.

6. Havu N, Mattson H, Ekman L, Carlsson E. Enterochromaffin-like cell carcinoids in rat gastric mucosa following long-term administration of ranitidine. Digestion 1990;45:189-95.

7. Tielemans $Y$, Håkanson $R$, Sundler $F$, Willems G. Proliferation of enterochromaffinlike cells in omeprazole treated hypergastrinemic rats. Gastroenterology 1989;96:723-29.

8. Waldum HL, Brenna E. Personal review: is profound acid inhibition safe? Aliment Pharmacol Ther 2000;14:15-20.

9. Haga Y, Nakatsura T, Shibata Y, Sameshima H, Nakamura Y, Tanimura M, et al. Human gastric carcinoid detected during long-term antiulcer therapy of $\mathrm{H}_{2}$ receptor antagonist and proton pump inhibitor. Dig Dis Sci 1998;43:253-57.

10. Solcia E, Capella C, Fiocca R, Rindi G, Rosai J. Gastric argyrophil carcinoidosis in patients with Zollinger-Ellison syndrome due to type 1 multiple endocrine neoplasia. A newly recognized association. Am J Surg Pathol 1990;14:503-14.

11. Bordi C, D'Adda T, Azzoni C, Pilato F, Caruana P. Hypergastrinemia and Gastric Enterochromaffin-Like Cells. Am J Surg Pathol 1995;19(Suppl 1):S8-S19.

12. Rode J, Dhillon AP, Papadaki L, Stockbrügger RW, Thompson RJ, Moss E, et al. Pernicious anaemia and mucosal endocrine cell proliferation of the non-antral stomach. Gut 1986;27:789-98.

13. Borch K, Renvall H, Liedberg G. Gastric endocrine cell hyperplasia and carcinoid tumors in pernicious anemia. Gastroenterology 1985;88:638-48.

14. Lamberts $R$, Creutzfeldt $W$, Strüber $H G$, Brunner $G$, Solcia E. Long-term omeprazole therapy in peptic ulcer disease: gastrin, endocrine cell growth and gastritis. Gastroenterology 1993;104:1356-1370.

15. Eissele R, Brunner G, Simon B, Solcia E, Arnold R. Gastric Mucosa During Treatment with Lansoprazole: Helicobacter pylori is a Risk Factor for Argyrophil Cell Hyperplasia. Gastroenterology 1997;112:707-17.

16. Kuipers EJ, Lundell L, Klinkenberg-Knol EC, Havu N, Festen HP, Liedman B, et al. Atrophic gastritis and Helicobacter pylori infection in patients with reflux esophagitis treated with omeprazole or fundoplication. N Engl J Med 1996;334:1018-22.

17. O'Connor DT, Deftos LS. Secretion of chromogranin A by peptide producing endocrine cells. N Engl J Med 1986;314:1145-51.

18. Stridsberg M, Öberg K, Li Q, Engstrom U, Lundqvist $G$. Measurement of chromogranin A, chromogranin B (secretogranin I), chromogranin C (secretogranin II) and pancreastatin in plasma and urine of patients with carcinoid tumours. $J$ Endocrinol 1995;144:49-59.

19. Håkanson $R$, Ding-XQ, Norlén $P$, Chen D. Circulating Pancreastatin Is a Marker for the Enterochromaffin-like Cells of the Rat Stomach. Gastroenterology $1995 ; 108: 1445-1452$. 
20. Stabile BE, Howard TJ, Pasaro E, O'Connor DT. Source of plasma chromogranin A elevation in gastrinoma patients. Arch Surg 1990;125:451-53.

21. Borch K, Stridsberg M, Burman P, Rehfeld JF. Basal chromogranin A and gastrin concentrations in circulation correlate to endocrine cell proliferation in type-A gastritis. Scand J Gastroenterol 1997;32:198-202.

22. Waldum HL, Arnestad JS, Brenna E, Eide I, Syversen U, Sandvik AK. Marked increase in acid secretory capacity after omeprazole treatment. Gut 1996;39:64953.

23. Houben GMP. Twenty-four-hour intragastric $\mathrm{pH}$, basal and meal-stimulated serum gastrin, and plasma chromogranin A after short-term acid inhibition. PhD thesis University of Maastricht, The Netherlands;1997:95-108; ISBN 9090106359.

24. Sanduleanu S, Stridsberg M, Jonkers D, Hameeteman W, Biemond I, Lundqvist $G$, et al. Serum gastrin and chromogranin A during medium- and long-term acid suppressive therapy: a case-control study. Aliment Pharmacol Ther 1999;13:14553.

25. Stridsberg $M$, Hellman $U$, Wilander $E$, Lundqvist $G$, Hellsing $K$, Öberg $K$. Fragments of chromogranin $A$ are present in the urine of patients with carcinoid tumours. J Endocrinol 1993;139:329-37.

26. Granberg D, Wilander E, Stridsberg M, Granerus G, Skogseid B, Öberg K. Clinical symptoms, hormone profiles, treatment, and prognosis in patients with gastric carcinoids. Gut 1998;43:223-28.

27. Lamers CB, van Tongeren JH. Comparative study of the value of the calcium, secretin, and meal-stimulated increase in serum gastrin to the diagnosis of the Zollinger-Ellison syndrome. Gut 1977;18(2):128-35.

28. Dixon MF, Genta RM, Yardley JH, Correa P. Classification and grading of gastritis. The updated Sydney system. Am J Surg Pathol 1996;20:1161-81.

29. Lloyd RV, Wilson BS. Specific endocrine tissue marker defined by a monoclonal antibody. Science 1983;222:628-30.

30. D'Adda T, Pilato FP, Lazzaroni M, Robutti F, Bianchi-Porro G, Bordi C. Ultrastructural morphometry of gastric endocrine cells before and after omeprazole. Gastroenterology 1991;100:1563-70.

31. Solcia E, Bordi C, Creutzfeldt W, Dayal $Y$, Dayan $A D$, Falkmer $S$, et al. Histopathological classification of nonantral gastric endocrine growths in man. Digestion 1988;41:185-200.

32. Jonkers D, Stobberingh E, de Bruïne A, Arends JW, Stockbrügger RW. Evaluation of immunohistochemistry for the detection of Helicobacter pylori in gastric mucosal biopsies. J Infect 1997;35:149-54.

33. Waldum HL, Brenna E. Trophic effect of gastrin on the enterochromaffin like cells of the rat stomach: Establishment of a dose response relationship. Gut 1992;33:1303-6.

34. Kimura K, Chen D, Lindström E, Zhao CM, Håkanson R. Evidence that rat stomach $\mathrm{ECL}$ cells represent the main source of circulating pancreastatin. Regul-Pept 1997;68(3):177-80.

35. Norlen P, Curry WJ, Chen D, Zhao CM, Johnson CF, Håkanson R. Expression of the chromogranin A- derived peptides pancreastatin and WE 14 in rat stomach ECL cells. Regul-Pept 1997;70(2-3):121-33.

36. Penston JG. Clinical assessment, gastrin concentrations and gastric histology after 5 years of maintenance treatment with ranitidine for duodenal ulcers. Scand J Gastroenterol 1990; 25(suppl 177):77-86.

37. Hsiao RJ, Mezger MS, O'Connor DT. Chromogranin A in uremia: progressive retention of immunoreactive fragments. Kidney Int.1990;37:955-64.

38. Kadmon D, Thompson TC, Lynch GR, Scardino PT. Elevated plasma chromogranin-A concentrations in prostatic carcinoma. J Urol 1991;146:358-61. 
39. Granberg D, Stridsberg $M$, Seensalu R, Eriksson B, Lundqvist $G$, Öberg $K$, et al. Plasma Chromogranin A in Patients with Multiple Endocrine Neoplasia Type 1. J Clin Endocrinol Metab 1999;84:2712-17.

40. Lewis JJ, Zdon MJ, Adrian TE, Modlin IM. Pancreastatin: a novel peptide inhibitor of parietal cell secretion. Surgery 1988;104:1031-36. 


\section{Chapter 5}

\section{Non-Helicobacter pylori bacterial flora during acid-suppressive therapy: differential findings in gastric juice and gastric mucosa}

S Sanduleanu, D Jonkers, A de Bruïne, W Hameeteman, RW Stockbrügger 


\section{Abstract}

\section{Background}

Intragastric growth of non-H.pylori bacteria commonly occurs during acid-suppressive therapy. The long-term clinical consequences are still unclear. The aim of this study was to investigate the luminal and mucosal bacterial growth during gastric acid inhibition, in relation to the type and duration of acid-inhibitory treatment, as well as to concomitant H.pylori infection.

\section{Methods}

145 patients on continuous acid inhibition with either proton pump inhibitors (PPIs, $n=109)$ or with histamine-2 receptor antagonists $\left(H_{2} R A s, n=36\right)$ for gastro-oesophageal reflux disease, and 75 dyspeptic patients without acid inhibition (control group) were included. At endoscopy, fasting gastric juice was obtained for $\mathrm{pH}$ measurement and bacteriological culture. Gastric biopsy specimens were examined for detection of H.pylori (immunohistochemistry [IMM]) and of non-H.pylori bacteria (modified Giemsa stain positive and IMM negative at the same location).

\section{Results}

Overall, non-H.pylori flora was detected in the gastric juice of $92(41.8 \%)$ patients and in the gastric mucosa of 109 (49.6\%) patients. In gastric juice, prevalence rate for nonH.pylori bacteria was higher in patients on PPIs than controls and $\mathrm{H}_{2} \mathrm{RAs}(58.7 \%$ vs $22.6 \%$ and vs $30.6 \%, P<0.0001$ and $P<0.003$, respectively), but did not differ statistically between $\mathrm{H}_{2}$ RAs and controls. In gastric mucosa, prevalence rates for non-H.pylori bacteria were higher in patients on PPIs and on $\mathrm{H}_{2} \mathrm{RAs}$ than in the controls (antrum: $46.9 \%$ and $48.6 \%$ vs $25 \%, \mathrm{P}<0.05$ for both; corpus: $52.2 \%$ and $56.8 \%$ vs $23.7 \%$, $\mathrm{P}<0.001$ for both), but did not differ between PPls and $\mathrm{H}_{2}$ RAs. Both luminal and mucosal growth of non-H.pylori bacteria were significantly greater in H.pylori-positive than -negative patients on PPIs ( $\mathrm{P}<0.05$ for both). Luminal growth of non-H.pylori flora increased with the intragastric $\mathrm{pH}$ level, while mucosal bacterial growth increased with the duration of acid inhibition.

\section{Conclusions}

Non-H.pylori flora not only contaminates the gastric juice but aiso colonises the gastric mucosa of a large proportion of patients treated long-term with acid inhibition. The relation between H.pylori and non-H.pylori bacteria in the pathogenesis of atrophic gastritis and gastric cancer needs further elucidation. 


\section{Introduction}

The acidic milieu of the stomach represents the first line of defence against ingested bacteria ${ }^{1,2}$. An intragastric $\mathrm{pH}$ below 4 has a bactericidal effect ${ }^{3}$, while gastric juice with a $\mathrm{pH}$ above 4 enables bacterial colonisation of the stomach ${ }^{4,5}$.

Decreased gastric acid output may occur as a consequence of Helicobacter pylori gastritis ${ }^{6}$ or may be iatrogenically induced by gastric surgery ${ }^{7}$ or administration of acid-suppressive therapy ${ }^{8,9}$. Earlier studies on intragastric bacterial overgrowth due to acid inhibitory medication brought into focus possible adverse events such as episodes of gastroenteritis ${ }^{10}$, development of malabsorption syndromes ${ }^{11}$, and formation of potentially carcinogenic $\mathrm{N}$-nitroso compounds ${ }^{12-16}$.

In recent years, considerable interest has emerged for the interactions between H.pylori, non-H.pylori bacteria, and acidsuppressive therapy. Some investigators have shown that, in H.pyloripositive patients, long-term acid suppression leads to a more rapid development of atrophic corpus gastritis, a condition associated with an elevated risk of gastric cancer ${ }^{17-21}$. Previous work of our group has indicated that this might be due to a co-infection of the stomach with non-H.pylori bacterial flora - secondary to acid inhibition ${ }^{22,23}$. It is therefore important to characterise more fully the determinants of nonH.pylori bacterial growth in such conditions.

In most clinical studies, the intragastric bacterial overgrowth was investigated by culture of gastric juice ${ }^{13-16}$ and only rarely of gastric mucosal tissue ${ }^{24}$. Recently, our group has proposed a semi-quantitative assessment of the non-H.pylori bacteria in gastric mucosa, using a nonspecific stain for total bacterial flora combined with a specific immunohistochemical stain for the detection of H.pylori ${ }^{25,26}$.

In the present study we investigated the gastric luminal and mucosal growth of non-H.pylori bacteria, in groups of patients treated with acid inhibition compared to non-treated controls, in order to estimate their potential pathogenetic effect on the gastric mucosa. Special attention was paid to the impact of clinical features, type, degree and duration of acid-suppressive therapy, as well as concomitant H.pylori infection on the luminal and mucosal non-H.pylori bacterial growth. 


\section{Patients and methods}

\section{Study population}

A total of 220 consecutive dyspeptic patients referred for upper gastrointestinal endoscopy to an open-access unit were enrolled in a cross-sectional, case-control study. Case subjects were patients on continuous acid-suppressive therapy for gastro-oesophageal reflux diseases (GORD), such as erosive and non-erosive oesophagitis and/or Barrett's oesophagus. Continuous acid suppression was defined as at least one daily dose of either a proton pump inhibitor (PPI) or a histamine ${ }_{2}$-receptor antagonist $\left(\mathrm{H}_{2} \mathrm{RA}\right)$, taken either 6 weeks to one year (medium-term) or longer than one year (long-term), respectively. Eligible controls were dyspeptic patients with a similar distribution of age and gender, who did not receive acid-suppressive medication or antacids before referral and who had normal endoscopic findings. Exclusion criteria for all patients were (1) present or past history of peptic ulcer disease; (2) previous gastric surgery and/or vagotomy; (3) prior H.pylori eradication therapy; (4) treatment with antimicrobial agents or prokinetic drugs within 30 days before endoscopy; (5) chronic use of NSAIDs; (6) other gastrointestinal or major non-gastrointestinal pathology, including immune-compromising states. The study was approved by the Ethical Review Board of the University Hospital Maastricht and each subject gave informed oral consent before entering into the study.

\section{Design of the study}

General clinical records and a structured interview concerning the history of reflux symptoms, type, daily dose, and duration of acidsuppressive medication, any comorbidity, comedication or family history of gastric cancer were obtained from all patients.

Endoscopy was performed after an overnight fast using a carefully disinfected Pentax EG-2901 instrument. At the beginning of endoscopy, a 5-10 $\mathrm{ml}$ sample of gastric juice was obtained - through the suction channel of the endoscope into a sterile trap - for bacteriological culture. Fasting gastric juice $\mathrm{pH}$ was measured using $\mathrm{pH}$ paper strips with grading steps of 0.5 from $\mathrm{pH} 0$ to $\mathrm{pH} 14$ (Schleicher \& Schüll $\mathrm{GmbH}$; Dassel, Germany) ${ }^{27}$. During endoscopy two antral biopsies $(2-3 \mathrm{~cm}$ proximal to the pylorus) and four corpus biopsies (midpart of the body mucosa, $4-5 \mathrm{~cm}$ above the corpus/antrum junction, along the greater curvature) were sampled for histological examination.

\section{Culture}

Samples of gastric juice were transported immediately to the laboratory and were processed within 4 hours. Culture was performed according to 
the five segments method, inoculating 1, 10 and $100 \mu$ onto each of the following plates: blood agar plates (Becton Dickinson 254098, Leiden, The Netherlands) for total bacterial counts, cysteine lactose electrolytedeficient agar plates (C.L.E.D., Becton Dickinson 255529, Leiden, The Netherlands) for Gram-negative rods, anaerobic blood agar plates (Becton Dickinson 254084, Leiden, The Netherlands) for total anaerobic bacterial counts, and selective plates for Helicobacter pylori. For the latter species, Campylobacter and chocolate agar plates were used, which were incubated under microaerophilic conditions, at $37^{\circ} \mathrm{C}$, for four to seven days. All other plates were incubated for a minimum of 48 hours with first reading at 24 hours for aerobes, and at 48 hours for anaerobes. Bacterial growth was assessed semi-quantitatively as colony forming units (CFU) per $\mathrm{ml}$ gastric juice, with a lowest detection limit of $10^{1} \mathrm{CFU} / \mathrm{ml}$ and an upper detection limit of $10^{7} \mathrm{CFU} / \mathrm{ml}$. The degree of bacterial colonisation was scored as follows: grade 0 , no bacteria detected; grade $1,<10^{3} \mathrm{CFU} / \mathrm{ml}$; grade $2,10^{4}-10^{6} \mathrm{CFU} / \mathrm{ml}$ and grade $3,>10^{6} \mathrm{CFU} / \mathrm{ml}$. Bacteria were identified by standard microbiological methods to species level ${ }^{28}$.

\section{Histopathology}

Serial sections of $4 \mu \mathrm{m}$ from formalin-fixed and paraffin-embedded specimens were prepared for haematoxylin-eosin stain (H\&E), modified Giemsa stain (MG) and an immunohistochemical stain (IMM). IMM with a purified polyclonal antiserum (DAKO B471, ITK diagnostics BV, Uithoorn, The Netherlands) in a dilution of 1:100 was applied to detect H.pylori. The presence of non-H.pylori bacterial flora was screened in the MG stain, by morphology and location of the bacteria, as described previously ${ }^{25,26}$. To ascertain the presence of non-H.pylori bacteria, the IMM stain of an adjacent section had to be H.pylori-negative on the same position. At least two adjacent sections of all biopsies were examined completely at $400 x$ magnification. If necessary a $1000 x$ magnification was used. This technique accurately detects the presence of non-H.pylori bacteria when compared to culture methods ${ }^{26}$.

The presence of both H.pylori and non-H.pylori bacteria was scored semi-quantitatively and graded as follows: grade 0 , no bacteria detected; grade 1, occasionally bacteria detected; grade 2, scattered bacteria identified in several high power fields; grade 3, large amounts detected in many high power fields ${ }^{29}$. All slides were reviewed by an experienced gastroenterological pathologist (A.B.) and by the main investigator (S.S.), without knowledge of patient identification. In the event of discordant results, the specimens were re-examined by a second pathologist and were discussed until agreement was reached. 


\section{Statistical analysis}

Differences in dichotomous variables were analysed using unpaired non-parametric tests (chi-square test with Yates correction) or paired non-parametric tests (Wilcoxon's rank-sum test). Differences in continuous variables were analysed using the Kruskal-Wallis test for multiple comparisons and the Mann-Whitney $U$ test for two group comparisons. Two-sided P-values $<0.05$ were assumed to indicate statistical significance.

\section{Results}

\section{Study population}

Two-hundred twenty consecutive patients were enrolled in the study. The demographic and relevant clinical features are detailed in Table 5.1. Patients were subdivided in three groups, on the basis of the type of acid-suppressive therapy they were receiving: a PPI group, a $\mathrm{H}_{2} \mathrm{RA}$ group, and non-treated controls, respectively. The age distribution and sex ratios did not differ statistically among the three patient groups.

Table 5.1. Demographic, clinical and endoscopic characteristics of 220 patients enrolled in the study.

\begin{tabular}{lccc}
\hline Characteristics & $\begin{array}{c}\text { Controls } \\
n=75\end{array}$ & $\begin{array}{c}\mathrm{H}_{2} \text { RA group } \\
n=36\end{array}$ & $\begin{array}{c}\text { PPI group } \\
n=109\end{array}$ \\
\hline Age (years) & $52(19-79)$ & $52(20-72)$ & $51.5(21-78)$ \\
Gender (male:female ratio) & $1.03: 1$ & $0.9: 1$ & $1.3: 1$ \\
Duration of acid inhibition (months) & - & $32(1.5-216)$ & $29(1.5-168)$ \\
Dose of medication (mg daily) & - & $300(150-450) \dagger$ & $40(20-80) \ddagger$ \\
Endoscopic findings (\%) & - & & \\
- GORD & - & 61.1 & 55.9 \\
- non-erosive & - & 33.3 & 15.0 \\
- erosive & - & 5.5 & 29.1 \\
Barrett's oesophagus & 100 & - & - \\
Normal findings & & & \\
\hline
\end{tabular}

*Data are expressed as median (range). Daily doses of tranitidine and of fomeprazole.

\section{Prevalence and density of bacterial flora in gastric juice and gastric mucosa}

Overall, $56(25.5 \%)$ patients displayed non-H.pylori bacteria simultaneously in gastric juice and in gastric mucosa, $36(16.3 \%)$ patients had non-H.pylori flora in gastric juice only, $53(24.1 \%)$ in gastric mucosa only, while the remaining $75(34.1 \%)$ patients had no evidence of non-H.pylori flora. 


\section{Gastric juice}

Table 5.2 describes the prevalence and density of non-H.pylori bacteria in the gastric juice. Patients on PPIs had higher prevalence of nonH.pylori bacteria, particularly oropharyngeal flora compared to the controls $(P<0.0001)$ and to the patients on $\mathrm{H}_{2} R A s(P<0.003)$, whereas no significant differences were noticed between the $\mathrm{H}_{2} \mathrm{RAs}$ and controls. Oropharyngeal flora, including Neisseria spp., Streptococci spp., and Corynebacterium spp. was identified in $16(21.3 \%)$ controls, in 10 (27.8\%) patients on $\mathrm{H}_{2} \mathrm{RAs}$ and in $64(58.7 \%)$ patients on PPIs. Gramnegative Enterobacteriaceae were recovered from one $(1.3 \%)$ control subject (Escherichia coli), one (2.8\%) patient on $\mathrm{H}_{2} \mathrm{RAs}$ (Escherichia coli and Proteus mirabilis) and five (4.6\%) patients on PPIs (Escherichia coli in three patients, Proteus mirabilis in one patient, Enterobacter gergoviae in one patient and Klebsiella oxytoca in one patient). Anaerobes (bacteroides species) were recovered from two patients on PPIs. In only $1(1.3 \%)$ control subject and $1(0.9 \%)$ patient on PPIs, H.pylori bacteria were isolated by culture of gastric juice.

Table 5.2. Prevalence and density of non-H.pylori bacterial flora in gastric juice.

\begin{tabular}{|c|c|c|c|}
\hline & $\begin{array}{c}\text { Controls } \\
n=75\end{array}$ & $\begin{array}{c}\mathbf{H}_{2} \mathbf{R A} \text { group } \\
n=36 \\
\end{array}$ & $\begin{array}{c}\text { PPI group } \\
n=109\end{array}$ \\
\hline \multicolumn{4}{|l|}{ Non-H.pylori flora } \\
\hline - Oropharyngeal-like (\%) & $16(21.3 \%)$ & $10(27.8 \%)$ & $64(58.7 \%) \dagger, \ddagger$ \\
\hline Grade $1 ; 2 ; 3$ & $3 ; 9 ; 4$ & $2 ; 4 ; 4$ & $2 ; 30 ; 32$ \\
\hline - Faecal-like (\%) & $1(1.3 \%)$ & $1(2.8 \%)$ & $5(4.6 \%)^{*}$ \\
\hline Grade $1 ; 2 ; 3$ & $0 ; 1 ; 0$ & $0 ; 1 ; 0$ & $1 ; 2 ; 2$ \\
\hline No flora & $58(77.3 \%)$ & $25(69.4 \%)$ & $45(41.3 \%)$ \\
\hline
\end{tabular}

$\dagger \mathrm{P}<0.0001$ vs controls and $\ddagger \mathrm{P}<0.003$ vs $\mathrm{H}_{2} \mathrm{RA}$ group.

*all 5 patients had both oropharyngeal-like and faecal-like flora.

\section{Gastric mucosa}

Figure 5.1 illustrates the presence and distribution of the H.pylori and non-H.pylori bacteria in the gastric mucosa of patients on acid inhibition and non-treated controls. The prevalence of H.pylori did not differ significantly between the three patient groups. However, the prevalence of non-H.pylori flora - in both antrum and corpus - was significantly higher in patients on acid suppression, either with PPIs or with $\mathrm{H}_{2} \mathrm{RAs}$, than controls [antrum: $\mathrm{P}=0.003$ and $\mathrm{P}=0.021$, respectively; corpus: $P<0.0001$ and $P<0.001$, respectively]. No significant difference in this respect was found between the PPI group and the $\mathrm{H}_{2} \mathrm{RA}$ group. The distribution of H.pylori between antral and corpus mucosa was similar in patients on $\mathrm{H}_{2}$ RAs and controls, while patients on PPIs had a lower prevalence of $H$.pylori in antral than corpus mucosa $(27.4 \%$ vs $34.5 \%$, 
$\mathrm{P}=0.033$ ). The distribution of non-H.pylori flora between antral and corpus mucosa did not differ significantly, within all three groups.

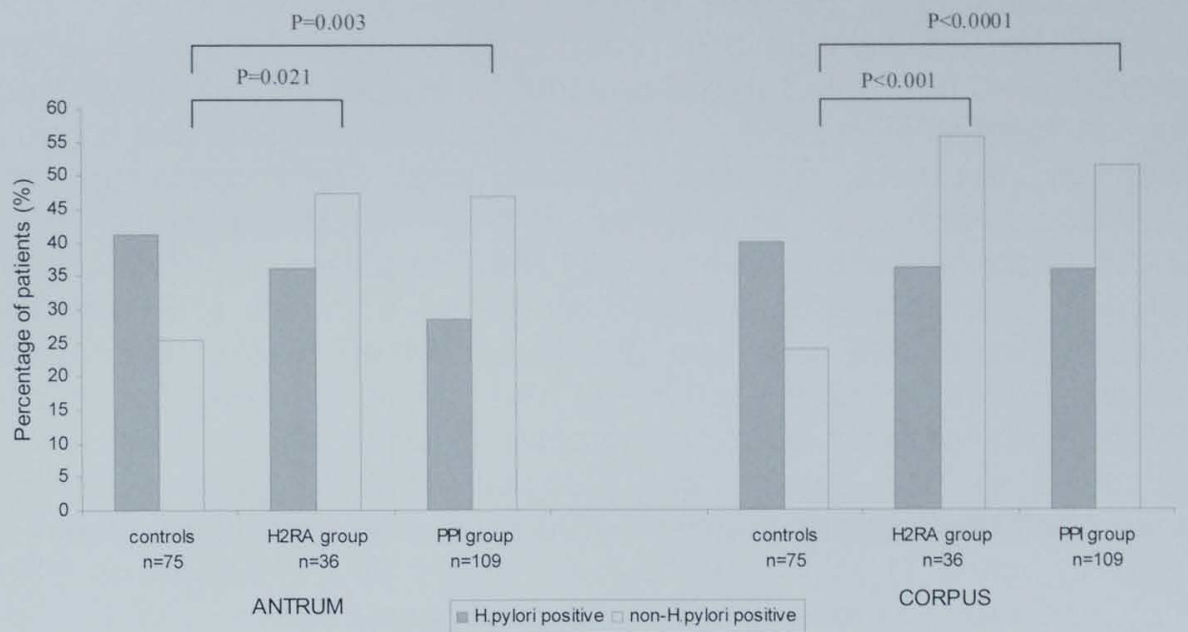

Figure 5.1. Prevalence and distribution of H.pylori and of non-H.pylori bacteria in gastric mucosa of patients on acid inhibition and non-treated controls.

Figures $5.2 \mathrm{a}$ and $\mathbf{5 . 2 b}$ depict the density of H.pylori and non-H.pylori bacteria in the antral and corpus mucosa. In the antral mucosa, patients on PPIs displayed lower density (grade 1-3) of H.pylori than controls $(P=0.002)$, whereas no significant differences were found between patients on $\mathrm{H}_{2} \mathrm{RAs}$ and controls, or between patients on PPIs and those on $\mathrm{H}_{2} \mathrm{RAs}$ (Figure 5.2a). In the corpus mucosa, a similar density of H.pylori was found among the three groups. The patients on acid suppression, either with PPIs or with $\mathrm{H}_{2} \mathrm{RAs}$ displayed higher density (grade 1-3) of non-H.pylori bacteria - in both antrum and corpus mucosa - compared to controls [antrum: $\mathrm{P}=0.012$ and $\mathrm{P}=0.005$; corpus: $\mathrm{P}=0.05$ and $P=0.024$, respectively] (Figure $\mathbf{5 . 2 b}$ ). No significant difference in the density of non-H.pylori flora was seen between the PPI group and the $\mathrm{H}_{2} \mathrm{RA}$ group. Also, within each group, no such differences were observed between antral and corpus mucosa.

Histologically, the non-H.pylori flora consisted mainly of cocci, although different types of rods were also detected. Most non-H.pylori bacteria were localised superficially, in the mucous layer (Figure 5.3a), but occasionally were also seen in the glandular lumina, on similar mucosal positions as the H.pylori (Figures 5.3b and 5.3c). 
(a)

H.pylori

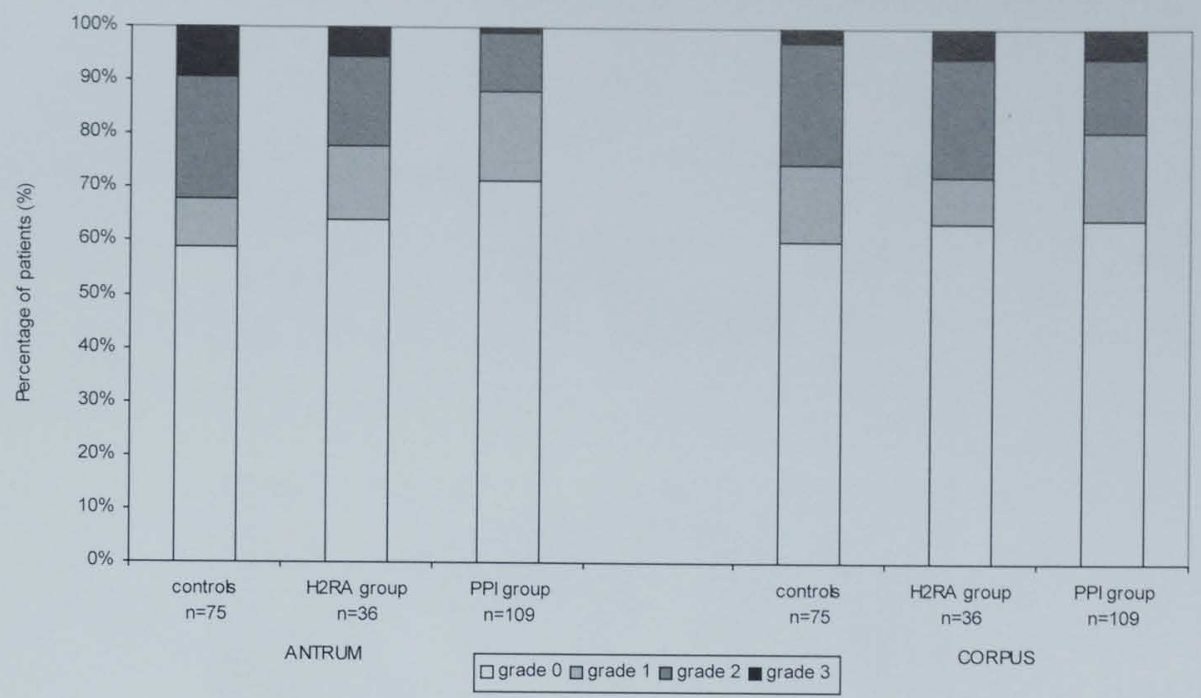

(b)

Non-H.pylori

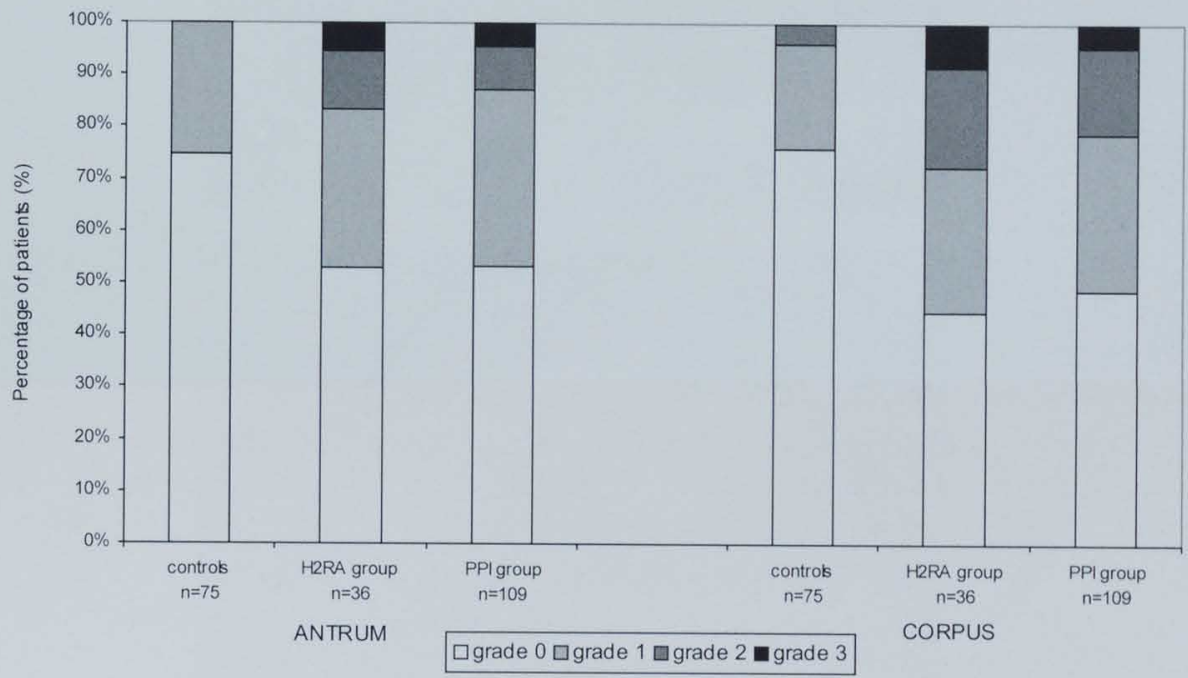

Figure 5.2. Density of H.pylori (a) and of non-H.pylori $(b)$ bacteria in gastric mucosa of patients on acid inhibition and non-treated controls. 
A

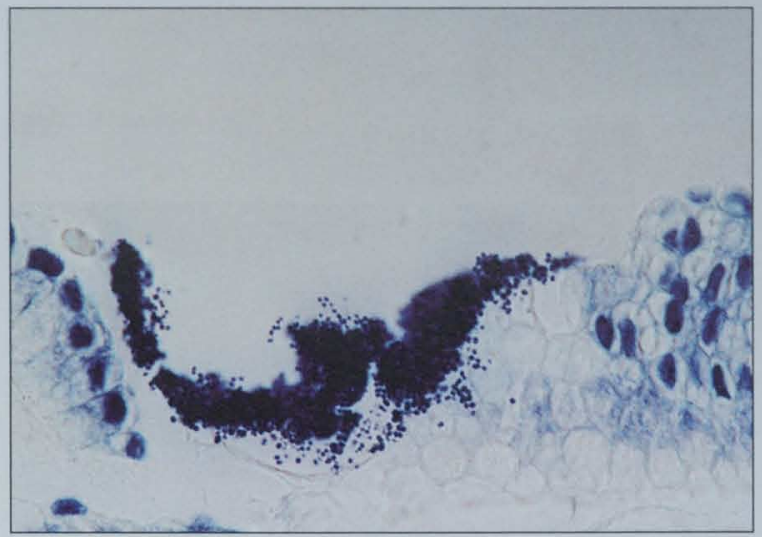

B

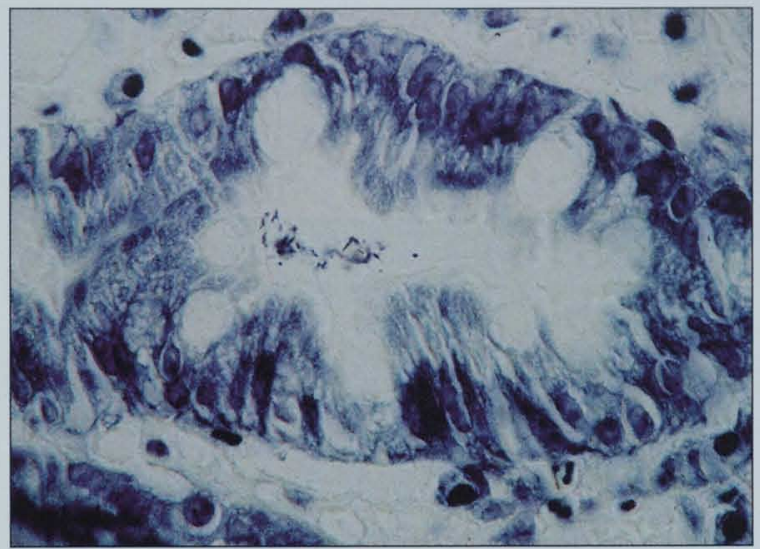

C

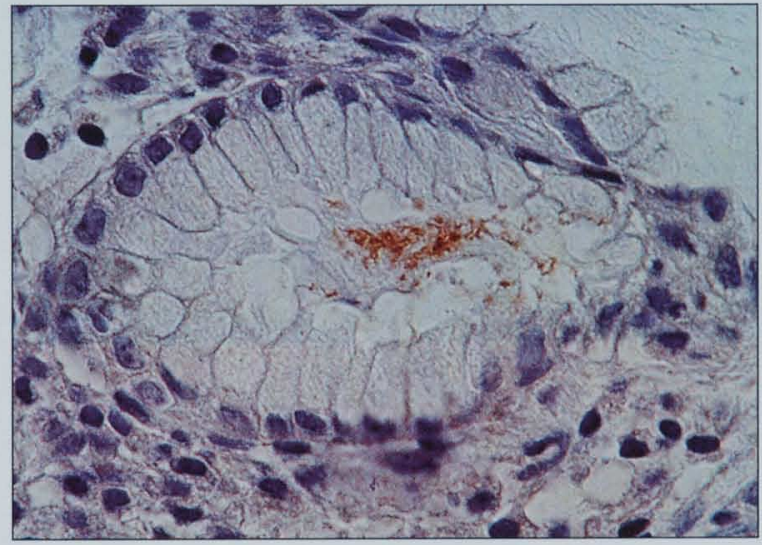

Figure 5.3. (A) Massive amounts of cocci present in the gastric mucous layer (1000x objective) from a patient treated long-term with proton pump inhibitors.

(B) Presence of cocci and rods in a gastric crypt from a patient with chronic atrophic gastritis and intestinal metaplasia.

Bacteria were identified as non-H.pylori species by MG (1000x objective) and simultaneous negative IMM.

(C) Presence of H.pylori in a gastric crypt by IMM (1000x objective). 


\section{Intragastric bacterial flora in relation to the type, degree and duration of acid-suppressive therapy}

Fasting gastric juice $\mathrm{pH}$ values above 4 were measured more frequently in patients on PPIs than in those on $\mathrm{H}_{2}$ RAs and controls $(71.6 \%$ vs $19.4 \%$ and $14.7 \%$, respectively, $P<0.0001$ for both), whereas no significant differences were noticed between patients on $\mathrm{H}_{2} \mathrm{RAs}$ and controls.

H.pylori-positive subjects had significantly higher fasting gastric juice $\mathrm{pH}$ than the H.pylori-negative, among all three groups (Figure 5.4). The highest gastric juice $\mathrm{pH}$ levels were observed in H.pylori-positive patients treated with PPIs. Also, in patients treated long-term with PPIs, the prevalence of non-H.pylori bacteria - in both gastric juice and gastric mucosa - was significantly higher in H.pylori-positive than -negative subjects (gastric juice: 26 of 32 [81.2\%] vs 32 of 55 [58.2\%], $\mathrm{P}=0.028$; gastric mucosa: 27 of 32 [84.3\%] vs 33 of 55 [60\%], $\mathrm{P}=0.018$, respectively).

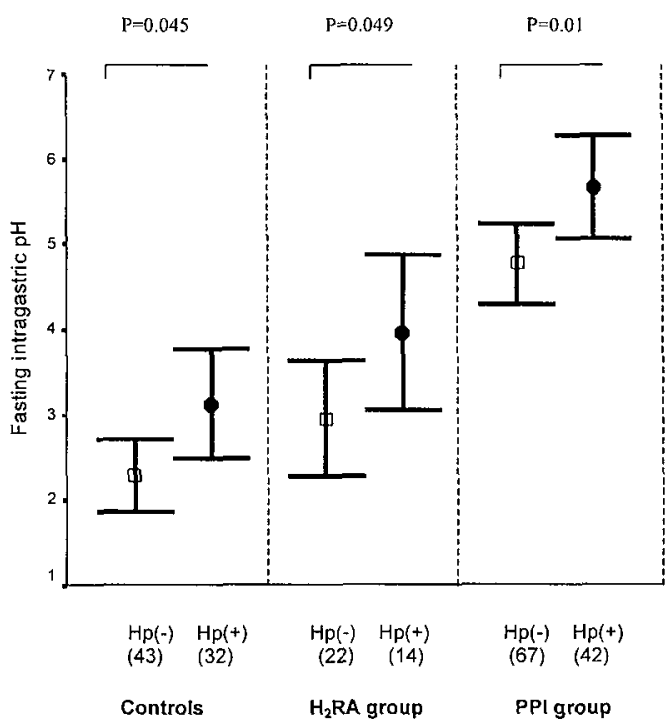

Figure 5.4. Median fasting gastric juice $\mathrm{pH}$ in H.pylori $(\mathrm{Hp})$ negative (I) and in H.pylori positive $(\bullet)$ subjects.

The error bars show the 10 th and the 90 th interquartile ranges

The patients with non-H.pylori bacteria in gastric juice were characterised by higher gastric juice $\mathrm{pH}$ level than those without it (Figure 5.5a). No such relation was found between the presence of 
non-H.pylori bacteria in the gastric mucosa and gastric juice $\mathrm{pH}$ level (Figure 5.5b).

(a)

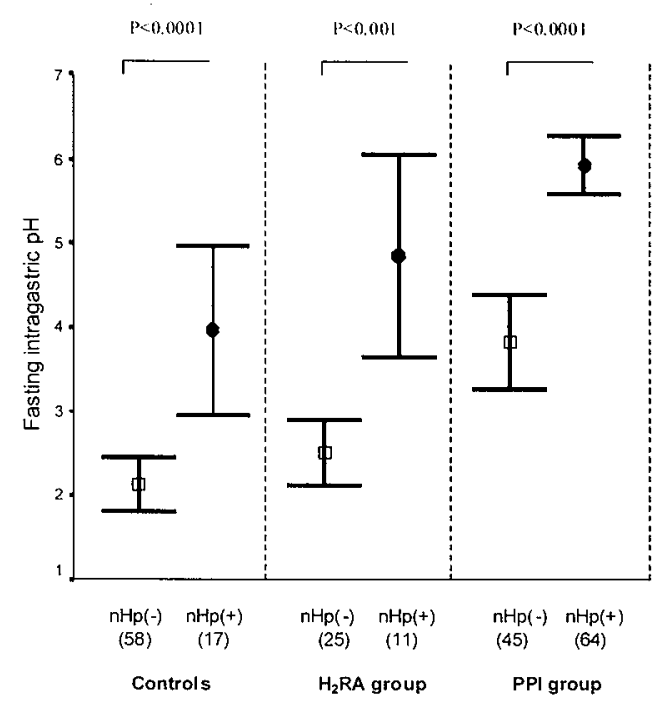

(b)

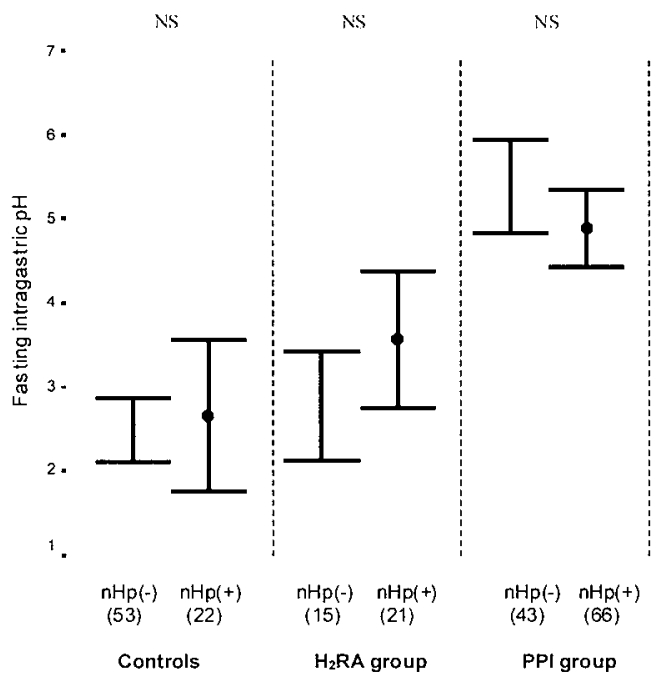

Figure 5.5. Median fasting gastric juice $\mathrm{pH}$ in patients without ( I) and in those with (•) non-H.pylori ( $\mathrm{nHp}$ ) bacteria in gastric juice (a) and gastric mucosa (b). The error bars show the 10 th and the 90th interquartile ranges. 
In the whole series five categories of patients were distinguished according to the duration of acid-suppressive therapy they had undergone (Figures 5.6a and 5.6b). Age and gender did not differ significantly among the five categories of patients $(P=0.76$ and $P=0.95$, respectively). In gastric juice, the prevalence of non-H.pylori bacteria increased with the duration of acid suppression in patients on PPIs, but not in those on $\mathrm{H}_{2}$ RAs $(\mathrm{P}<0.0001$ and $\mathrm{P}=0.63$ for patients treated $>36$ months $v s$ those treated $<12$ months, respectively) (Figure 5.6a). In gastric mucosa, the prevalence of non-H.pylori bacteria increased with the duration of acid suppression, regardless of the type of antisecretory medication $(P<0.0001$ and $P<0.05$ for patients treated with $P P I s$ and with $\mathrm{H}_{2} \mathrm{RAs}>36$ months $v s<12$ months, respectively) (Figure 5.6b).

\section{Discussion}

The current study documented a high prevalence and density of the non-H.pylori bacterial flora in the gastric mucosa of patients on acidsuppressive therapy. Previous reports have mainly focused on the luminal bacterial growth during natural and artificial hypochlorhydria and achlorhydria ${ }^{3-5}$. Hitherto, only very few studies provided insights into the mucosal bacterial growth ${ }^{24}$, and none at all investigated the relationship between the two intragastric compartments.

\section{Gastric luminal non-H.pylori bacterial growth}

In the present study, fasting gastric juice $\mathrm{pH}$ levels were higher in H.pylori-positive compared to H.pylori-negative subjects, especially in the PPI-treated group. Also, H.pylori-positive patients on PPIs were more likely to be infected with non-H.pylori bacteria than the H.pylorinegative patients. These findings are in line with those from previous studies showing a greater elevation of the intragastric $\mathrm{pH}$ in H.pyloriinfected vs non-infected patients treated with acid inhibition ${ }^{30,31}$, which in turn may cause an enhanced colonisation of the stomach with nonH.pylori flora ${ }^{32}$.

The bacterial species isolated from the gastric juice were mainly of oropharyngeal origin - with Streptococci, Neisseria and Corynebacterium as the most common species - while only a few patients harboured faecal-type flora - especially Escherichia coli, Proteus and Klebsiella species. The growth of faecal-like bacteria in gastric juice during pharmacological acid inhibition describes large variations among studies, ranging from very few ${ }^{15,33}$ to as many as $30 \%$ or more of the treated patients ${ }^{16}$. These discrepancies may reflect differences in population samples and methodologies. As an alternative or additional 
explanation, a higher susceptibility to acid of such flora - compared to the oropharyngeal-like bacterial species - may prevent its isolation ${ }^{33}$.

(a)

\section{Gastric juice}
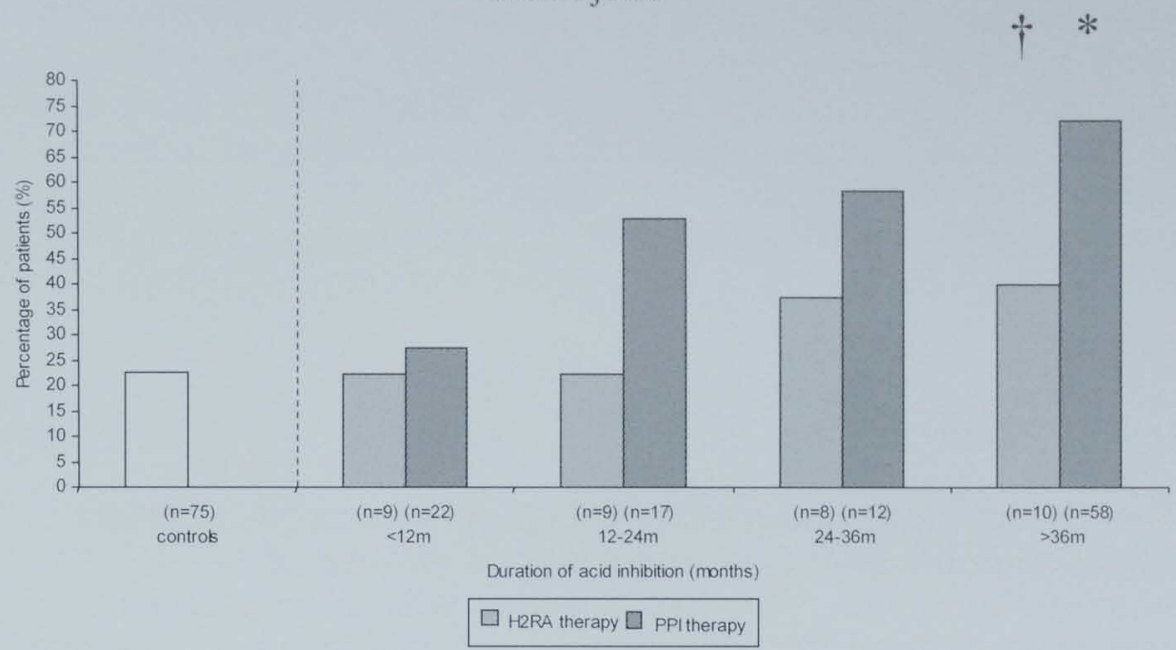

$* \mathrm{P}<0.0001$ and $\dagger \mathrm{P}=0.63$ vs patients treated $<12$ months.

(b)

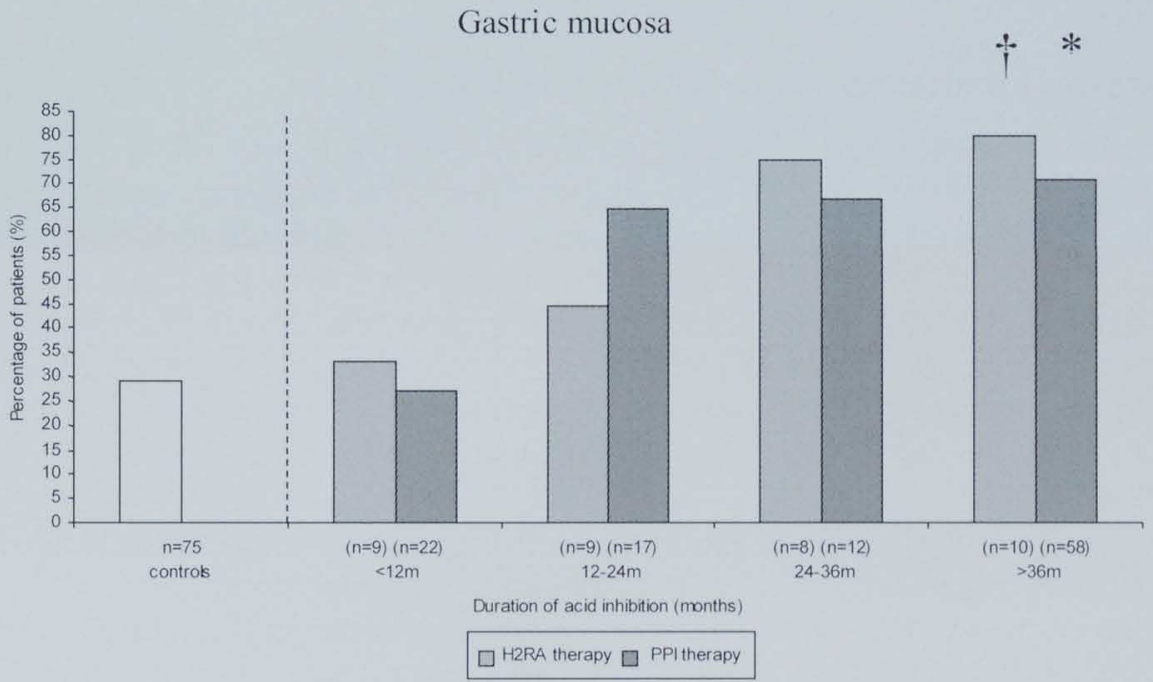

$* \mathrm{P}<0.0001$ and $+\mathrm{P}<0.05$ vs patients treated $<12$ months.

Figure 5.6. Non-H.pylori bacterial flora in gastric juice (a) and in gastric mucosa (b) in relation with the type and duration of acid inhibition. 


\section{Gastric mucosal non-H.pylori bacterial growth}

In the current study, gastric mucosal bacterial growth was detected in about $50 \%$ of the patients on acid inhibition, mainly after long-term treatment. Of particular note was the observation that non-H.pylori bacteria developed with a similar prevalence and density in the gastric mucosa of patients treated either with PPIs or with $\mathrm{H}_{2}$ RAs. This finding adds support to previously published data showing that intragastric bacterial growth may occur during acid inhibition with any type of effective antisecretory drug ${ }^{12-16}$.

Interestingly, nearly half of the patients with histological evidence of non-H.pylori bacteria, had a "sterile" gastric juice at the time of examination. As illustrated in Figures $5.6 \mathrm{a}$ and $5.6 \mathrm{~b}$, this was particularly evident in patients treated with $\mathrm{H}_{2}$ RAs. It can be reasoned therefore that the fluctuations in the intragastric $\mathrm{pH}$ - which are far more commonly encountered during $\mathrm{H}_{2} \mathrm{RA}$ therapy - dynamically influence the luminal bacterial growth. In contrast, the gastric mucosa during acid inhibition seems to behave as a constant "bacterial reservoir".

The discrepancy between luminal and mucosal growth of nonH.pylori flora also suggests that although hypochlorhydria - with subsequent colonisation of gastric juice - is a prerequisite for the colonisation of the mucosa, the latter may depend upon additional factors. It can be speculated that on a background of compromised gastric mucosal barrier - secondary to the H.pylori infection - the resident non-H.pylori bacteria display pathogenic properties adhering to and even penetrating into the mucosa. As illustrated in Figures $\mathbf{5 . 3 b}$ and $\mathbf{5 . 3 c}$, the identification of non-H.pylori bacterial species on similar mucosal positions as the H.pylori supports this hypothesis.

Unfortunately, in the present study we did not assess the bacterial composition in the gastric mucosa by means of microbiological culture. However, Dolby et $a^{24}$ have found a similar spectrum of microorganisms in cultures of gastric juice and of gastric tissue. In view of this finding and of our own observations ${ }^{26}$, it is conceivable that the similar composition of the two intragastric compartments reflects a twoway interaction: not only can the gastric juice non-H.pylori bacteria colonise the gastric mucosa, but with the constant renewal of the mucosa, the bacteria might flow back into the gastric lumen, as well.

\section{General considerations and conclusions}

The results of our study may trigger the question: Is the mucosal nonH.pylori bacterial growth of pathogenetic significance? It has been largely debated whether bacterial colonisation of the stomach - during several conditions associated with hypochlorhydria - increases the risk of gastric cancer through nitrosamine synthesis ${ }^{34,35}$. Also, it has been 
suggested that non-H.pylori bacteria and their by-products may act as a persistent antigenic stimulus, and thereby augment the inflammatory response induced by the H.pylori infection ${ }^{22,23}$. The resulting cumulative damage to the mucosa caused by a double infection of the stomach with H.pylori and non-H.pylori bacteria may in the long term lead to development of atrophic gastritis and ultimately of gastric cancer.

The results of this study may also have relevance for clinical bacteriological research. We have shown that the sole assessment of luminal bacterial growth by culturing gastric juice - as performed in earlier studies - seems to underestimate the changes in the intragastric milieu. In addition, the semi-quantitative histological evaluation of the non-H.pylori flora used in this study provides information regarding the morphology and location of the bacteria, thus being a useful complement to the standard microbiological methods.

In summary, our study clearly demonstrates that the non-H.pylori bacterial flora not only contaminates the gastric juice but also colonises the gastric mucosa of a large proportion of patients on continuous acid inhibitory medication. This seems to be largely influenced by the infection with H.pylori and the length of antisecretory therapy, either with $\mathrm{H}_{2}$ RAs or with PPIs. Further studies are needed to elucidate the role of the double infection of the stomach with H.pylori and non-H.pylori bacteria in the pathogenesis of atrophic gastritis and of gastric cancer. 


\section{References}

1. Gianella RA, Broitman SA, Zamcheck N. Gastric acid barrier to ingested microorganisms in man: studies in vivo and in vitro. Gut 1972;13:251-6.

2. Hunt RH. The protective role of gastric acid. Scand J Gastroenterol 1988;23(S 146):34-9.

3. Wilder-Smith $\mathrm{CH}$, Spirig $\mathrm{C}$, Krech $\mathrm{T}$, Merki HS. Bactericidal factors in gastric juice. Eur J Gastroenterol Hepatol 1992;4:885-91.

4. Stockbrügger RW, Cotton PB, Menon GG, Beilby JO, Bartholomew BA, Hill MJ, et al. Pernicious anaemia, intragastric bacterial overgrowth, and possible consequences. Scand J Gastroenterol 1984;19:355-64.

5. Stockbrügger RW. Bacterial overgrowth as a consequence of reduced gastric acidity. Scand J Gastroenterol 1985;S 111:7-16.

6. El-Omar EM, Oien K, El-Nujumi A, et al. Helicobacter pylori infection and chronic gastric acid hyposecretion. Gastroenterology 1997;113:15-24.

7. Enander LK, Nilsson F, Ryden AC, Schwan A. The aerobic and anaerobic microflora of the gastric remnant more than 15 years after Billroth II resection. Scand J Gastroenterol 1982;17:715-20.

8. Festen HPM. Profound gastric acid inhibition. Advantages and potential hazards. Scand J Gastroenterol 1989;24(S 171):99-105.

9. Modlin IM, Goldenring JR, Lawton GP, Hunt R. Aspects of the theoretical basis and clinical relevance of low acid states. Am J Gastroenterol 1994;89:308-18.

10. Wingate DL. Acid reduction and recurrent enteritis. Lancet 1990;i:222.

11. Saltzman JR, Kowsley KV, Pedrosa MC, et al. Bacterial overgrowth without clinical malabsorption in elderly hypochlorhydric patients. Gastroenterology 1994;106:61523.

12. Stockbrügger RW, Cotton PB, Eugenides N, Bartholomew BA, Hill MJ, Walters CL. Intragastric nitrates, nitrosamines, and bacterial overgrowth during cimetidine treatment. Gut 1982;23:1048-54.

13. Sharma BK, Santana IA, Wood EC, et al. Intragastric bacterial activity and nitrosation before, during, and after treatment with omeprazole. BMJ 1984;289:717-9.

14. Verdu E, Viani F, Armstrong D, et al. Effects of omeprazole on intragastric bacterial counts, nitrates, nitrites, and N-nitroso compounds. Gut 1994;35:445-60.

15. Houben GMP, Hooi J, Brummer RJ, Stobberingh EE, Stockbrügger RW. Intragastric bacterial growth, nitrates and $\mathrm{N}$-nitroso compounds after $300 \mathrm{mg}$ ranitidine b.d., $20 \mathrm{mg}$ omeprazole, $40 \mathrm{mg}$ omeprazole and placebo. Eur J Cancer Prevention 1996;5(S 1):59-61.

16. Brummer RJ, Stockbrügger RW. Effect of nizatidine $300 \mathrm{mg}$ at night and omeprazole $20 \mathrm{mg}$ in the morning on 24-hour intragastric $\mathrm{pH}$ and bacterial overgrowth in patients with acute duodenal ulcer. Dig Dis Sci 1996;41;2048-54

17. Logan RPH, Walker MM, Misiewicz JJ, Gummett PA, Karim QN, Baron JH. Changes in the intragastric distribution of Helicobacter pylori during treatment with omeprazole. Gut 1995;36:12-6.

18. Kuipers EJ, Lundell L, Klinkenberg-Knoll E, et al. Atrophic gastritis and Helicobacter pylori infection in patients with reflux esophagitis treated with omeprazole or fundoplication. N Engl J Med 1996;334:1018-22.

19. Lundell L, Miettinen P, Myrvold HE, et al. Lack of effect of acid suppression therapy on gastric atrophy. Gastroenterology 1999;117:319-26. 
20. Jönsson KA, Ström M, Bodemar $G$, Norrby $K$. Histologic changes in the gastroduodenal mucosa after ling-term medical treatment with cimetidine or parietal cell vagotomy in patients with juxtapyloric ulcer disease. Scand $J$ Gastroenterol 1988;23:433-41.

21. Meining A, Bosseckert H, Caspary WF, Nauert C, Stolte M. H2-receptorantagonists as well as antacids have an aggravating effect on Helicobacter pylori gastritis in duodenal ulcer patients. Aliment Pharmacol Ther 1997;11:729-34.

22. Sanduleanu $S$, Jonkers $D$, de Bruine A, Hameeteman W, Stockbrügger RW. Double gastric infection with Helicobacter pylori and non-Helicobacter pylori bacteria enhances the expression of circulating pro-inflammatory cytokines and parallels the development of atrophic corpus gastritis. Gut 2000;47(S III):A110.

23. Sanduleanu $S$, Jonkers $D$, de Bruine $A$, Hameeteman $W$, Stockbrügger RW. Does double infection of the stomach with Helicobacter pylori and non-Helicobacter pylori bacterial flora accelerate the development of atrophic gastritis in patients treated with gastric acid inhibition ? Gut 2000;47(S III):A31.

24. Dolby JM, Webster ADB, Borriello SP, Barclay FE, Bartholomew BA, Hill MJ. Bacterial colonization and nitrate concentration in the achlorhydric stomachs of patients with primary hypogammaglobulinaemia or classical pernicious anaemia. Scand J Gastroenterol 1984;19:105-10.

25. Jonkers D, Gisbertz I, de Bruine A, et al. Helicobacter pylori and non-Helicobacter pylori bacterial flora in gastric mucosal and tumour specimens of patients with primary gastric lymphoma. Eur J Clin Investigation 1997;27:885-92.

26. Jonkers D, Houben P, Hameeteman W, et al. Differential features of gastric cancer patients, either Helicobacter pylori positive or Helicobacter pylori negative. Ital J Gastroenterol Hepatol 1999;31:836-41.

27. Bonten M, Gaillard C, Stockbrügger RW, van-Tiel F, van-der-Geest S, Stobberingh $\mathrm{E}$. Assessment of gastric acidity in intensive care patients: intermittent $\mathrm{pH}$ registration cannot replace continuous $\mathrm{pH}$ monitoring. Intensive Care Med $1996 ; 22(3): 220-5$.

28. Balows A, Hausler WJ, Hermann KL, Isenberg HD, Shadomy HJ. Manual of Clinical Microbiology, 5th edition; American Society For Microbiology, Washington DC, 1991.

29. Dixon MF, Genta RM, Yardley JA, Correa P. Classification and grading of gastritis. The updated Sydney System. Am J Surg Pathol 1996;20:1161-81.

30. Verdú EF, Armstrong D, Fraser R, et al. Effect of Helicobacter pylori status on intragastric $\mathrm{pH}$ during treatment with omeprazole. Gut 1995;36(4):539-43.

31. Labenz J, Tillenburg B, Peitz $U$, et al. Helicobacter pylori augments the $\mathrm{pH}$ increasing effect of omeprazole in patients with duodenal ulcer. Gastroenterology 1996;110(3):725-32.

32. Gillen D, Williams C, Hossack M, Gilmore D, McColl KEL. Helicobacter pylori infection predisposes to gastric colonisation by other bacteria during omeprazole treatment. Gut 1998;42(1):A3.

33. Karmeli Y, Stalnikowitz R, Eliakim R, Rahav G. Conventional dose of omeprazole alters gastric flora. Dig Dis Sci 1995;40(9):2070-3.

34. Hill MJ. Bacterial N-nitrosation and gastric carcinogenesis in humans. Ital J Gastroenterol 1991;23:17-23.

35. Houben GM, Stockbrügger RW. Bacteria in the aetio-pathogenesis of gastric cancer: a review. Scand J Gastroenterol 1995;212:13-8. 


\section{Chapter $\mathbf{6}$}

Double gastric infection with Helicobacter pylori and non-Helicobacter pylori bacteria during acid-suppressive therapy: increase of pro-inflammatory cytokines and development of atrophic gastritis

S Sanduleanu, D Jonkers, A de Bruïne, W Hameeteman, RW Stockbrügger

Aliment Pharmacol Ther 2001;15:1163-75 


\section{Abstract}

\section{Background}

Long-term acid suppression accelerates the development of atrophic gastritis in H.pylori-positive subjects. The pathogenetic mechanism remains unclear. This study tested the hypothesis that the gastric double infection with H.pylori and non-H.pylori bacterial species - during acid suppression - may result in an enhanced inflammatory response, contributing to development of atrophic gastritis.

\section{Patients \& Methods}

A consecutive series of patients with gastro-oesophageal reflux disease undergoing treatment with proton pump inhibitors $(n=113)$ or histamine ${ }_{2}$-receptor antagonists $(n=37)$, and 76 non-treated dyspeptic controls was investigated. Gastric mucosal H.pylori and non-H.pylori bacteria, histological gastritis, H.pylori serology, and circulating interleukin (IL)-1 $\beta, \mathrm{IL}-6$, and IL-8 were examined.

\section{Results}

Patients on acid suppression with either PPIs or $\mathrm{H}_{2} \mathrm{RAs}$ had similar prevalence of H.pylori infection to the controls, but a higher prevalence of non-H.pylori bacteria $(61.1 \%$ and $59.5 \%$ vs $28.9 \%, P<0.0001$ and $\mathrm{P}<0.002$ respectively). Both the presence of H.pylori and non-H.pylori bacteria were independent risk factors of atrophic gastritis (antrum: RRs, 10.1 and 5.07; corpus: RRs, 11.74 and 6.38). Simultaneous presence of H.pylori and non-H.pylori bacteria was associated with a markedly increased risk of atrophic gastritis (antrum: RR, 20.25; corpus: RR, 20.38), compatible with a synergistic effect. Furthermore, the simultaneous presence of both types of bacteria was associated with higher cytokine levels than in patients without any type of bacteria. This increase was also greater than in patients with H.pylori infection alone $(P<0.001$, for both $\mathrm{IL}-1 \beta$ and $\mathrm{IL}-8$ ).

\section{Summary \& conclusions}

H.pylori-positive patients on long-term acid inhibition displayed three features: nonH.pylori bacterial growth, increased cytokine levels, and a high risk of atrophic gastritis. We suggest that the double infection with H.pylori and non-H.pylori bacteria is a major factor in the development of atrophic gastritis during gastric acid inhibition. 


\section{Introduction}

Identification of Helicobacter pylori (H.pylori) has considerably improved our understanding of the pathogenesis of chronic atrophic gastritis ${ }^{1,2}$. Infection with H.pylori causes chronic active inflammation of the gastric mucosa, which may progress towards atrophic gastritis and intestinal metaplasia, conditions that increase the risk of gastric cancer ${ }^{3,4}$. The clinical outcome of the infection is driven by a complex interplay between bacterial pathogenic factors, host response, and environmental factors ${ }^{5,6}$.

Current evidence indicates that the anatomical distribution and severity of H.pylori gastritis are strongly influenced by the individual gastric acid secretory status ${ }^{7,8}$. Subjects with a normal or high level of acid output are prone to develop antral predominant gastritis and duodenal ulcer disease. In contrast, subjects with a low level of acid output are prone to develop a corpus (body) predominant gastritis, leading to glandular atrophy and risk of gastric cancer. Such corpus predominant gastritis is frequently seen when H.pylori-infected subjects are treated with acid-suppressive medication ${ }^{9-12}$. At present, the mechanism underlying the accelerated development of atrophic gastritis in H.pylori-infected patients treated with acid inhibition is still unclear. It has been suggested that an increase in antral $\mathrm{pH}$ impairs local growth conditions for H.pylori, causing a 'shift' of the bacterium to the corpus mucosa, where the acid secretion is still preserved ${ }^{9}$. Furthermore, decreased gastric acid secretion may impair the dilution and washout of potentially cytotoxic and pro-inflammatory agents induced by H.pylori, which in turn may cause mucosal damage ${ }^{11,13}$.

On the other hand, acid suppression alters the intragastric milieu, favouring the colonisation by non-H.pylori bacterial species: aerobic and to a minor degree anaerobic, gram-positive and gram-negative bacterial strains have been consistently isolated ${ }^{14-18}$. The intragastric bacterial overgrowth and its potential consequences have received considerable attention in the past ${ }^{14}$. So far, it is not known whether such bacteria could play a role in the development of atrophic gastritis during acidsuppressive therapy.

Infection with H.pylori induces mucosal over-expression of various pro-inflammatory cytokines, such as interleukin (IL)-1 $\beta, \mathrm{IL}-6, \mathrm{IL}-8$, and tumour necrosis factor $\alpha$; this is accompanied by gastric morphological changes ${ }^{19-21}$. Experimental evidence shows that commensal bacteria and their by-products can also elicit cytokine production ${ }^{22,23}$. In this context, the following question emerged: Does the gastric double infection with H.pylori and non-H.pylori bacteria cause an enhanced 
inflammatory response, leading to increased risk for development of atrophic gastritis?

In a large series of patients on continuous acid-suppressive therapy and of non-treated controls, we tested this hypothesis by studying intragastric mucosal bacterial flora in relation to the profile of circulating pro-inflammatory cytokines - IL-1 $\beta, \mathrm{IL}-6$, and IL-8 - and to gastric mucosal histology. Special attention was paid to the development of corpus atrophic gastritis in this clinical setting.

\section{Patients and methods}

\section{Study population}

Between January 1997 and June 1998, 226 consecutive dyspeptic patients referred for upper gastrointestinal endoscopy to an openaccess unit (University Hospital Maastricht, The Netherlands) were investigated in a cross-sectional design. Case subjects were patients on continuous acid-suppressive therapy for gastro-oesophageal reflux disease (GORD), with/without Barrett oesophagus. Continuous acidsuppressive therapy was defined as at least one daily dose of either a proton pump inhibitor (PPI) or a histamine ${ }_{2}$-receptor antagonist $\left(\mathrm{H}_{2} \mathrm{RA}\right)$, taken either six weeks to one year (medium-term) or longer than one year (long-term), respectively. Control subjects were dyspeptic patients with a similar distribution of age and gender, who did not receive any acid-suppressive medication or antacids before referral, and who had normal endoscopic findings. Exclusion criteria for all subjects were: (1) present or past history of peptic ulcer disease; (2) previous gastric surgery and/or vagotomy; (3) prior H.pylori eradication therapy; (4) treatment with antimicrobial agents or prokinetic drugs within 30 days before endoscopy; (5) chronic use of NSAIDs; (6) any condition suspected or confirmed to influence the cytokine production, such as an acute infection in the previous 30 days, non-infectious inflammatory diseases, neoplasms, liver or renal diseases, use of immunosuppressive therapy. The study was approved by the Ethical Review Board of the University Hospital Maastricht and each subject gave informed consent before being enrolled into the study.

\section{Design of the study}

General clinical records and a structured interview concerning history of reflux symptoms, type, daily dose, and length of antisecretory therapy, any comorbidity / comedication, and family history of gastric cancer were obtained from all patients. Endoscopies were performed after an overnight fast, using a carefully disinfected Pentax EG-2901 instrument. 
During endoscopy, fasting gastric juice $\mathrm{pH}$ was measured using $\mathrm{pH}$ paper strips with grading steps of 0.5 from pH 0 to $\mathrm{pH} 14$ (Schleicher \& Schüll $\mathrm{GmbH}$; Dassel, Germany). Two antral biopsies (2 $\mathrm{cm}$ proximal to the pylorus) and four corpus biopsies $(10 \mathrm{~cm}$ below the gastrooesophageal junction, along the greater curvature) were sampled for histological examination. Fasting blood samples were obtained for the determination of H.pylori status and circulating cytokines. All blood samples were drawn between 9:00 am and 11:00 am.

\section{Serological tests}

The H.pylori status of the patients was determined using an immunoblot method (Helicoblot 2.0, Imphos BV, Zambon Group, Amersfoort, The Netherlands). Strips were incubated with serum samples, diluted 1:100. After washing, they were treated with anti-human IgG antibody conjugated with alkaline phosphatase and the substrate BCIP/NBT. Bands were present for 19.5, 26.5, 30, 35, 89, and $116 \mathrm{kD}$ (CagA) proteins. H.pylori positivity was assessed according to the manufacturer's instructions. H.pylori positive and negative control sera were included each time the test was performed.

Circulating IL-1 $\beta, I L-6$, and IL-8 levels were determined by ELISA (Cytoscreen $^{\text {TM }}$ human IL-1 $\beta$ ELISA kit, BioSource International, California, USA; IL-6 ELISA kit IBL-Hamburg, Germany, and Genzyme IL-8 ELISA kit, Cambridge, USA, respectively). The detection limit for all these assays is $1 \mathrm{pg} / \mathrm{ml}$. The intra-assay variations of IL-1 $\beta, \mathrm{IL}-6$, and IL-8 are less than $5 \%, 4.5 \%$, and $6.5 \%$, whilst the inter-assay variations of these cytokines are less than $7.5 \%, 5.5 \%$, and $10.5 \%$. All samples were examined in duplicate and without knowledge of the patients' clinical and histologic data.

\section{Histology}

Serial sections $(4 \mu \mathrm{m})$ from formalin-fixed and paraffin-embedded specimens were prepared for haematoxylin-eosin stain (H\&E), modified Giemsa stain (MG), and an immunohistochemical stain (IMM).

For the detection and histological classification of the current intragastric bacterial flora, the IMM and MG were used in combination, as previously detailed ${ }^{24-26}$. IMM with a polyclonal antiserum (DAKO B471, ITK diagnostics BV, Uithoorn, The Netherlands) in a dilution of 1:100 was applied to detect H.pylori ${ }^{24}$. The presence of non-H.pylori bacteria was screened in the MG stain - on the basis of morphology and location - and ascertained by a negative IMM stain of an adjacent section, on the same position, as detailed elsewhere ${ }^{25,26}$. At least two adjacent sections of all biopsies were examined completely at $400 \mathrm{x}$ magnification. If necessary a $1000 x$ magnification was used. This 
technique was validated against culture methods, in groups of patients with different gastric conditions, as well as in the context of acid inhibitory treatment ${ }^{24,26}$.

The histomorphologic status of the gastric mucosa was evaluated according to the Sydney classification ${ }^{27-30}$. The presence of active inflammation (i.e., neutrophilic cell infiltration), chronic inflammation (i.e., mononuclear cell infiltration), glandular atrophy (i.e., loss of appropriate glands), and intestinal metaplasia was graded as absent, mild, moderate or severe changes. The density of non-H.pylori bacterial colonisation was scored semiquantatively, as follows: grade 0 (no bacteria detected); grade 1 (occasionally bacteria detected); grade 2 (scattered bacteria identified in several high power fields); and grade 3 (large amounts detected in many high power fields) ${ }^{28}$.

For the purpose of this study, the following subtypes of chronic gastritis were considered: diffuse non-atrophic gastritis, defined as active and/or chronic inflammation of either antral, corpus or both antral and corpus mucosa, without any signs of glandular atrophy; antral predominant atrophic gastritis (APAG), defined as glandular atrophy detected only in the antrum or in both antrum and corpus, but with a higher degree of active or chronic inflammation in the antrum; and corpus predominant atrophic gastritis (CPAG), defined as glandular atrophy detected only in the corpus or in both antrum and corpus, but with a higher degree of active or chronic inflammation in the corpus. All biopsy specimens were reviewed by one experienced gastroenterological pathologist (A.B.) and by the main investigator (S.S.), without knowledge of the patients' clinical and serological data. In the event of discordant results (less than $5 \%$ of all cases), the specimens were re-examined by a second pathologist and were discussed until agreement was reached.

\section{Statistical evaluation}

Differences in dichotomous variables were examined using the $\chi^{2}$ test or Fisher's exact test, when appropriate. Differences in continuous variables were examined using the Kruskal-Wallis test for multiple comparisons and the Mann-Whitney $U$ test for two group comparisons. Correlations were performed with the Spearman rank test. The concordance between histological (IMM) and serological evidence of $H . p y l o r i$ was tested with $k$ statistics ( $k$ index). Univariate analyses using as outcome variable the presence of atrophic gastritis were computed for each potential risk factor: age, gender, duration of acid-suppressive therapy, CagA positivity, presence of H.pylori alone, of non-H.pylori alone, and of both types of bacteria. Multiple logistic regression analyses were carried out to determine the independent contribution of each factor to the presence of atrophic gastritis ${ }^{31}$. Interaction was 
studied with standard methods ${ }^{32}$. The relative excess risk due to an interaction was calculated as: relative risk ( $A$ and $B$ ) - relative risk ( $A$ without $B$ ) - relative risk ( $B$ without $A)+1$, where $A$ and $B$ are the factors whose interaction is being studied. The synergy index was calculated as: [relative risk (A and $B)-1$ ] / [relative risk (A without $B)+$ relative risk (B without $A$ ) - 2]. In the multiple regression analysis, a relative excess risk $>0$ and a synergy factor $>1$ were regarded as indices of interaction between two risk factors. Two-sided P-values $<0.05$ were assumed to indicate statistical significance.

\section{Results}

Table 6.1 shows the demographic, clinical, and endoscopic characteristics of the 226 patients, classified according to the type of acid-suppressive therapy they were undergoing. The age distribution and sex ratios were comparable among the three patient groups: nontreated controls, $\mathrm{H}_{2} \mathrm{RA}$ group, and PPI group.

Median gastric juice $\mathrm{pH}$ levels in H.pylori-positive patients were 3.1 (2.5-3.8) in non-treated controls, $4.0(2.9-4.9)$ in the $\mathrm{H}_{2} \mathrm{RA}$ group, and 5.6 (4.8-6.5) in the PPI group; the corresponding median gastric juice $\mathrm{pH}$ levels in H.pylori-negative patients were 2.2 (1.8-2.7), 3.0 (2.3-3.6), and $4.8(4.2-5.2)$, respectively.

Table 6.1. Demographic, clinical and endoscopic characteristics of the 226 patients enrolled into the study.

\begin{tabular}{lccc}
\hline Characteristics & Controls & \multicolumn{2}{c}{ Acid inhibition } \\
& & H $_{2}$ RA group & PPI group \\
\hline Number of patients & 76 & 37 & 113 \\
Age (years) & $51.5(19-79)$ & $52(20-73)$ & $51(21-78)$ \\
Male:female ratio & $1.05: 1$ & $0.95: 1$ & $1.3: 1$ \\
Duration of acid inhibition & - & $32(1.5-216)$ & $29(1.5-168)$ \\
(months) $^{\star}$ & - & $300(150-450) \dagger$ & $40(20-80) \ddagger$ \\
Dose of medication (mg daily) & - & 2.7 & 3.5 \\
First degree relatives with & 2.6 & & \\
gastric cancer (\%) & & 5.5 & 29.2 \\
Endoscopic findings (\%) & - & 32.4 & 15.0 \\
- Barrett oesophagus & - & 62.1 & 55.8 \\
- erosive oesophagitis & 100 & & \\
- normal oesophagus & & & \\
\hline
\end{tabular}

*Data are expressed as median (range). Daily doses of ranitidine† and of omeprazoleł. 
Prevalence and distribution of intragastric bacteria in the gastric mucosa

Figure 6.1 illustrates the prevalence of H.pylori and non-H.pylori bacteria in the gastric mucosa. The patients on acid suppression with either PPIs or $\mathrm{H}_{2} \mathrm{RAs}$ had similar prevalence of H.pylori infection to nontreated controls, but a higher prevalence of non-H.pylori bacteria $(61.1 \%$ and $59.5 \%$ vs $28.9 \%, P<0.0001$ and $P<0.002)$. No significant difference in this regard was found between the PPI group and the $\mathrm{H}_{2} \mathrm{RA}$ group.

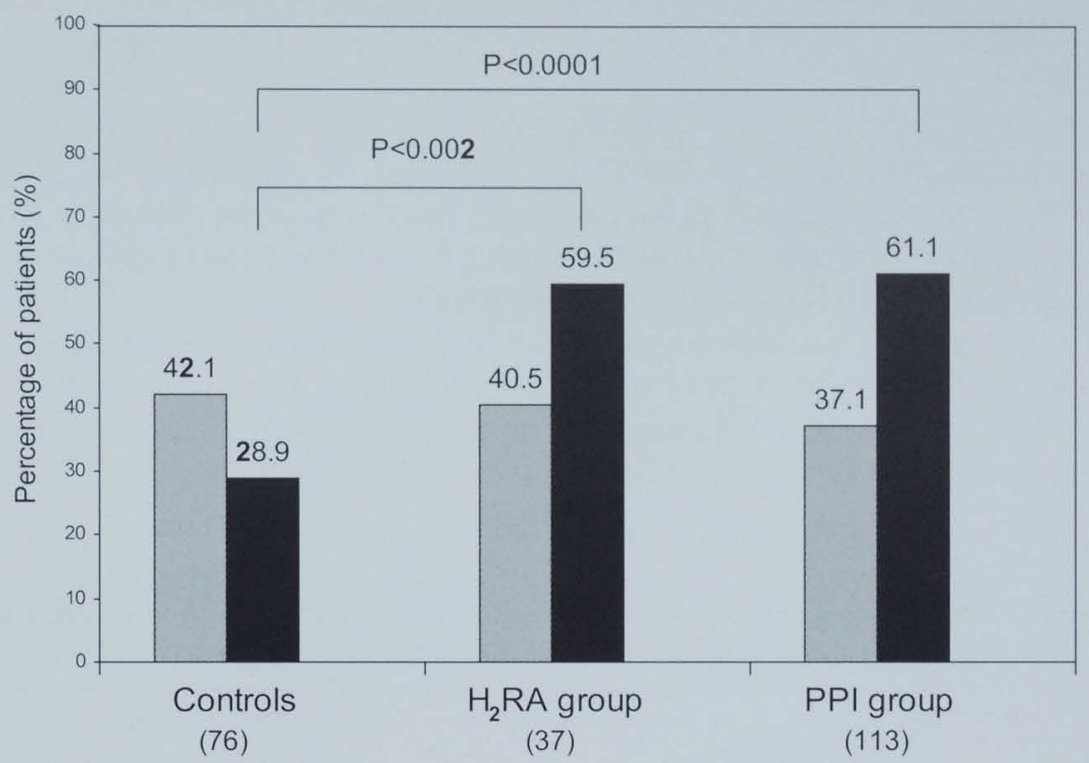

H.pylori positive non-H.pylori positive

Figure 6.1. Prevalence of H.pylori and non-H.pylori bacteria in the gastric mucosa of 226 subjects enrolled into the study.

The distribution of H.pylori between antral and corpus mucosa was similar in patients treated with $\mathrm{H}_{2} \mathrm{RAs}$ and controls, whilst patients treated with PPIs had a lower prevalence of H.pylori colonisation in antral than corpus mucosa (27.4\% vs $34.5 \%, \mathrm{P}=0.033)$ (Table 6.2). There were no significant differences in prevalence of non-H.pylori bacteria between antral and corpus mucosa in each of the three patient groups.

The patients on acid suppression with either PPIs or with $\mathrm{H}_{2} \mathrm{RAs}$ had also higher median scores (grade 1-3) of non-H.pylori bacterial density in both the antrum and corpus mucosa - than the controls [antrum: 
$P=0.012$ and $P=0.003$; corpus: $P=0.05$ and $P=0.028$, respectively] (Table 6.2). No significant differences in this regard were found between the PPI group and the $\mathrm{H}_{2} \mathrm{RA}$ group, or between antral and corpus mucosa within each of the three patient groups.

Tabel 6.2. Distribution pattern and density of colonisation by H.pylori and non-H.pylori bacteria.

\begin{tabular}{|c|c|c|c|}
\hline & \multirow[t]{2}{*}{ Controls } & \multicolumn{2}{|c|}{ Acid inhibition } \\
\hline & & $\mathrm{H}_{2} \mathrm{RA}$ group & PPI group \\
\hline \multicolumn{4}{|l|}{$\begin{array}{l}\text { H.pylori } \\
\text { antral mucosa }\end{array}$} \\
\hline prevalence $(\%)$ & 40.8 & 37.8 & $27.4^{\star}$ \\
\hline density (median score) & $1(1-3)$ & $1(1-3)$ & $1(1-3)$ \\
\hline \multicolumn{4}{|l|}{ corpus mucosa } \\
\hline prevalence (\%) & 39.5 & 37.8 & 34.5 \\
\hline density (median score) & $1(1-3)$ & $1(1-3)$ & $1(1-3)$ \\
\hline \multicolumn{4}{|l|}{$\begin{array}{l}\text { Non-H.pylori bacteria } \\
\text { antral mucosa }\end{array}$} \\
\hline prevalence $(\%)$ & 25.0 & 48.6 & 46.9 \\
\hline density (median score) & $1(1-3)$ & $2(1-3) \dagger$ & $2(1-3) \dagger$ \\
\hline \multicolumn{4}{|l|}{ corpus mucosa } \\
\hline prevalence (\%) & 23.7 & 56.8 & 52.2 \\
\hline density (median score) & $1(1-3)$ & $2(1-3) \dagger$ & $2(1-3) \dagger$ \\
\hline
\end{tabular}

* Lower prevalence of H.pylori in the antral vs corpus mucosa in patients treated with PPIs ( $P=0.033$ ).

† Higher density of non-H.pylori bacteria in patients treated with PPIs or with $\mathrm{H}_{2} \mathrm{RAs}$ than in the controls (antrum: $P=0.012$ and $P=0.003$; corpus: $P=0.05$ and $P=0.028$ ).

\section{Intragastric bacteria in relation to chronic gastritis}

Overall, $39(17.2 \%)$ patients had diffuse non-atrophic gastritis, 44 $(19.5 \%)$ patients had antral predominant atrophic gastritis (APAG), and $28(12.4 \%)$ had corpus predominant atrophic gastritis (CPAG), whilst the remaining $115(50.9 \%)$ patients had normal gastric histology. In patients with APAG, antral gland atrophy was mild in 22 cases, moderate in 14 cases, and severe in 8 cases. In patients with CPAG, corpus gland atrophy was mild in 6 cases, moderate in 12 cases, and severe in 10 cases. Of the 44 patients with APAG, 38 had intestinal metaplasia, which in 28 cases was mild, in 6 cases was moderate, and in the remaining 4 was severe. Of the 28 patients with CPAG, 20 had intestinal metaplasia, which in 10 cases was mild, in 6 cases was moderate, and in 4 cases was severe.

In patients with APAG, H.pylori only, non-H.pylori only and both types of bacteria were detected in $15(34.1 \%), 10(22.7 \%)$, and $17(38.6 \%)$ of the 44 cases, whereas the corresponding figures in patients with CPAG were $9(32.1 \%), 7(25 \%)$, and $11(39.3 \%)$ of the 28 cases, respectively. 
Overall, there was strong concordance between histology (IMM) and serology for the presence of H.pylori (controls, 95\% agreement, $k=0.89$; $\mathrm{H}_{2} \mathrm{RAs}, 94 \%$ agreement, $k=0.84$; PPls, $90 \%$ agreement, $k=0.81$ ). CagA antibodies were found in $62(69.7 \%)$ of the histologically H.pyloripositive subjects (22 of 32 [68.8\%] controls, 11 of 15 [73.3\%] patients on $\mathrm{H}_{2} \mathrm{RAs}$, and 29 of 42 [69\%] patients on PPIs). In histologically H.pylori-positive subjects, APAG was more common in CagA-positive than CagA-negative subjects $(P=0.024)$, but no such relation was found between CagA positivity and CPAG $(P=0.42)$.

In Table 6.3 , the results of the multiple logistic regression analysis examining independent risk factors for the development of atrophic gastritis are detailed. Age was associated with a minor - but significant risk of atrophic gastritis, whilst gender did not influence this outcome. In contrast to antral atrophic gastritis, the risk of corpus atrophic gastritis increased with the duration of acid inhibition, as expressed per year of treatment. The corresponding relative risk after ten years of therapy can be estimated at $3.16(95 \% \mathrm{Cl}, 2.79-3.58)$. CagA positivity was a risk factor for antral atrophic gastritis, but not for corpus atrophic gastritis.

Table 6.3. Results of multivariate analyses to determine the independent risk factors of atrophic gastritis in antrum and corpus.

\begin{tabular}{|c|c|c|c|}
\hline $\begin{array}{l}\text { Risk factor } \\
\text { Outcome: antral predominant atrophic gastritis }\end{array}$ & \multicolumn{2}{|c|}{$\begin{array}{c}\text { Adjusted odds ratio } \\
(95 \% \mathrm{CI})\end{array}$} & P-value \\
\hline Age (per decade) & 1.04 & $(1.01-1.07)$ & 0.018 \\
\hline Gender (female vs male) & 0.86 & $(0.42-1.80)$ & 0.70 \\
\hline Duration of acid-suppressive therapy (years) & 1.07 & $(0.95-1.22)$ & 0.24 \\
\hline CagA positivity & 2.67 & $(1.12-6.41)$ & 0.028 \\
\hline H.pylori vs no bacteria & 10.10 & $(2.14-47.61)$ & 0.003 \\
\hline Non-H.pylori vs no bacteria & 5.07 & $(1.05-24.40)$ & 0.043 \\
\hline Both H.pylori and non-H.pylori vs no bacteria* & 20.25 & $(4.27-96.08)$ & 0.0002 \\
\hline \multicolumn{4}{|l|}{ Outcome: corpus predominant atrophic gastritis } \\
\hline Age (per decade) & 1.04 & $(1.01-1.07)$ & 0.024 \\
\hline Gender (female vs male) & 0.51 & $(0.21-1.26)$ & 0.40 \\
\hline Duration of acid-suppressive therapy (years) & 1.12 & $(1.02-1.30)$ & 0.021 \\
\hline CagA positivity & 1.6 & $(0.4-5.8)$ & 0.62 \\
\hline H.pylori vs no bacteria & 11.74 & $(1.41-97.80)$ & 0.022 \\
\hline Non-H.pylori vs no bacteria & 6.38 & $(0.78-53.89)$ & 0.088 \\
\hline Both H.pylori and non-H.pylori vs no bacteriat & 20.38 & $(2.46-168.55)$ & 0.005 \\
\hline
\end{tabular}

H.pylori infection alone was an independent risk factor of atrophic gastritis in both antrum and corpus. The presence of non-H.pylori bacteria alone independently increased the risk of antral atrophic 
gastritis, but only as a trend in the gastric corpus. The simultaneous presence of H.pylori and non-H.pylori bacteria was associated with the highest risk of atrophic gastritis in antrum and corpus when compared to the risk by either type of bacteria alone. The relative excess risk due to the interaction between H.pylori and non-H.pylori bacteria was 6.08 for APAG and 3.26 for CPAG, compatible with a synergistic effect (synergy index of 1.46 and 1.26, respectively). Analysis of the data based on serological - instead of histological - evidence of H.pylori provided similar results (data not shown).

\section{Circulating cytokines in relation to intragastric bacteria and chronic gastritis}

In the entire series, four subgroups of patients were distinguished according to the presence of H.pylori and of non-H.pylori bacteria in the gastric mucosa: patients without any type of bacteria (64 cases), with H.pylori alone (49 cases), with non-H.pylori bacteria alone (73 cases), and with both types of bacteria (40 cases). Patients infected with H.pylori alone had higher levels of IL-1 $\beta$ and IL-8 (Figures 6.2A and 6.2B) than those without any type of bacteria $(P<0.0001$, for both cytokines). Patients with non-H.pylori bacteria alone had slightly higher IL-1 $\beta$ and IL-8 levels than those without any type of bacteria, but differences reached statistical significance for $I L-8$ only $(P<0.05)$. Patients harbouring both H.pylori and non-H.pylori bacteria had threefold higher levels of circulating IL-1 $\beta$ and IL-8 than those without any type of bacteria ( $P<0.0001$, for both cytokines); this increase was also greater than that in patients with H.pylori infection alone $(P<0.001$, for both cytokines).

Table 6.4 describes the relationship between cytokine levels and different types of chronic gastritis. Patients with diffuse non-atrophic gastritis, patients with APAG, and especially those with CPAG had significantly higher circulating IL-1 $\beta, I L-6$, and IL-8 levels than those with normal gastric histology. As illustrated in Figure 6.3, in patients with APAG or with CPAG, cytokine levels - particularly IL-8 - were highest in patients with double infection and severe atrophic gastritis. As shown in Figure 6.4, in patients with CPAG, cytokine levels positively correlated with the histological degree of glandular atrophy. Also, CagA-positive subjects had significantly higher IL-8 levels than CagA-negative subjects $(3.6[0-12.9] \mathrm{pg} / \mathrm{ml}$ vs $2.4[0-10.4] \mathrm{pg} / \mathrm{ml}, \mathrm{P}=0.012)$, but no such relation was found between CagA positivity and IL-1B (P=0.12) or IL-6 $(P=0.26)$ levels. 
(a)

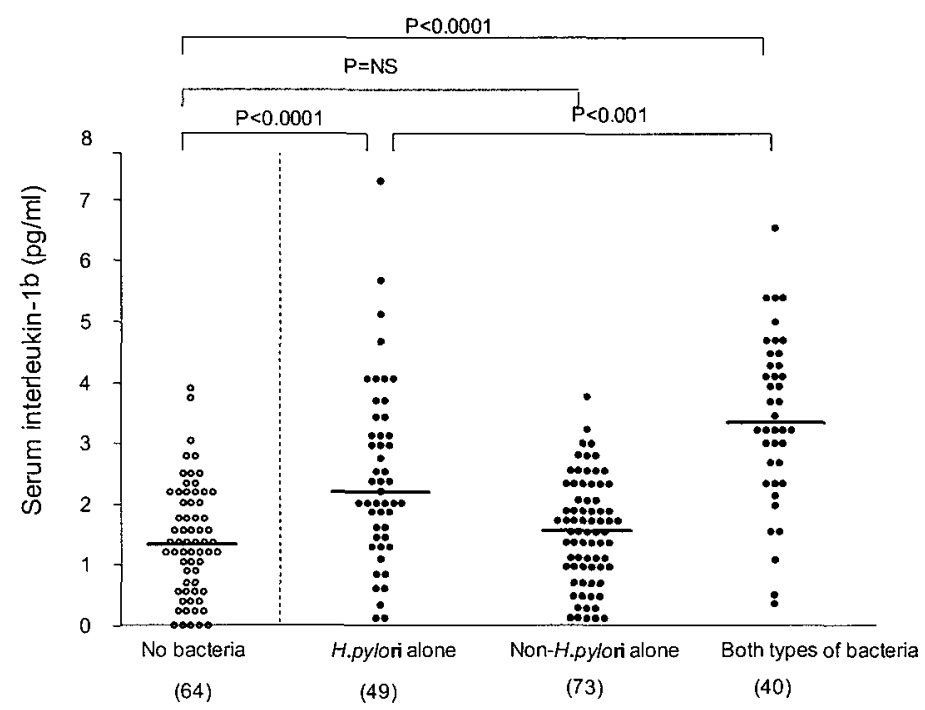

(b)

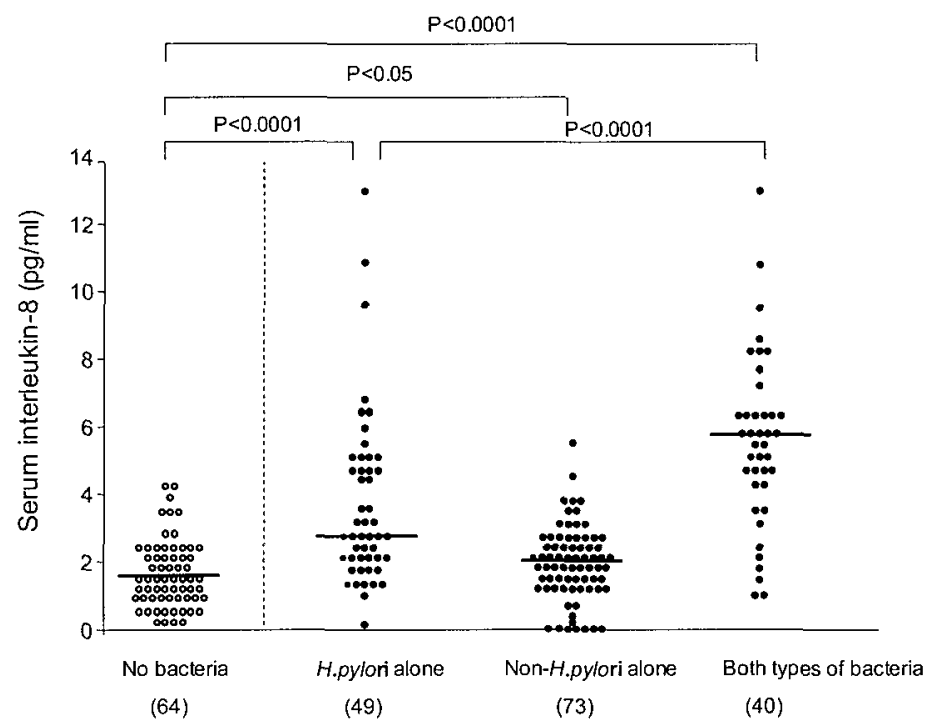

Figure 6.2. Individual values of circulating IL-1 $\beta$ (a) and IL-8 (b) in subjects with H.pylori alone, non-H.pylori alone, or with both types of bacteria compared to those without bacteria in the gastric mucosa. Median values are shown by horizontal lines. Numbers of subjects in parentheses. 
Table 6.4. Circulating cytokines in relation to different types of chronic gastritis.

\begin{tabular}{lccc}
\hline & $\begin{array}{c}\text { Circulating } \\
\mathrm{IL}-1 \mathrm{~B}(\mathrm{pg} / \mathrm{ml})\end{array}$ & $\begin{array}{c}\text { Circulating } \\
\mathrm{IL}-6(\mathrm{pg} / \mathrm{mI})\end{array}$ & $\begin{array}{c}\text { Circulating } \\
\mathrm{IL-8}(\mathrm{pg} / \mathrm{ml})\end{array}$ \\
\hline $\begin{array}{l}\text { Normal gastric histology } \\
(\mathrm{n}=115)\end{array}$ & $1.5(0-4.2)$ & $0.8(0-7)$ & $1.7(0-5.5)$ \\
$\begin{array}{l}\text { Diffuse non-atrophic gastritis } \\
(\mathrm{n}=39)\end{array}$ & $2.3(0.3-7.3)^{* *}$ & $1.4(0.1-7)^{\star *}$ & $3.2(0-12.9)^{* *}$ \\
$\begin{array}{l}\text { Antral predominant atrophic gastritis } \\
(\text { APAG, } n=44)\end{array}$ & $2.3(0.1-5.5)^{*}$ & $1.1(0-3.8)$ & $2.6(0-10.8)^{\star *}$ \\
$\begin{array}{l}\text { Corpus predominant atrophic gastritis } \\
(\text { CPAG, } n=28)\end{array}$ & $3.3(0.1-6.5)^{\star * *}$ & $1.9(0.6-17.3)^{* * *}$ & $5.6(0.1-12.9)^{\star * *}$ \\
\hline
\end{tabular}

Patients with diffuse non-atrophic gastritis, patients with APAG, but especially those with CPAG had higher circulating cytokine levels than those with normal gastric histology. Values are expressed as medians (interquartile ranges).

${ }^{*} \mathrm{P}<0.05 ;{ }^{* *} \mathrm{P}<0.01$; ${ }^{\star * *} \mathrm{P}<0.001$ vs those with normal gastric histology.

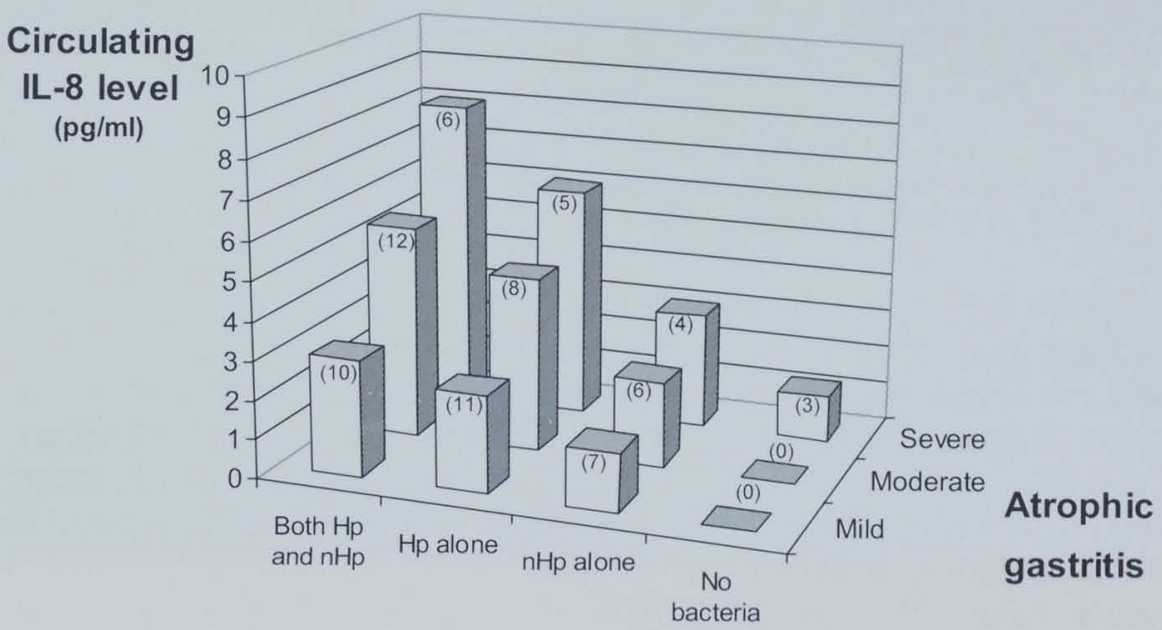

Figure 6.3. Relationship between intragastric bacteria, circulating cytokines (IL-8 level), and the histological degree of atrophic gastritis. Median IL-8 values are shown by columns. Numbers of subjects in parentheses. Patients with APAG and with CPAG are shown together. 


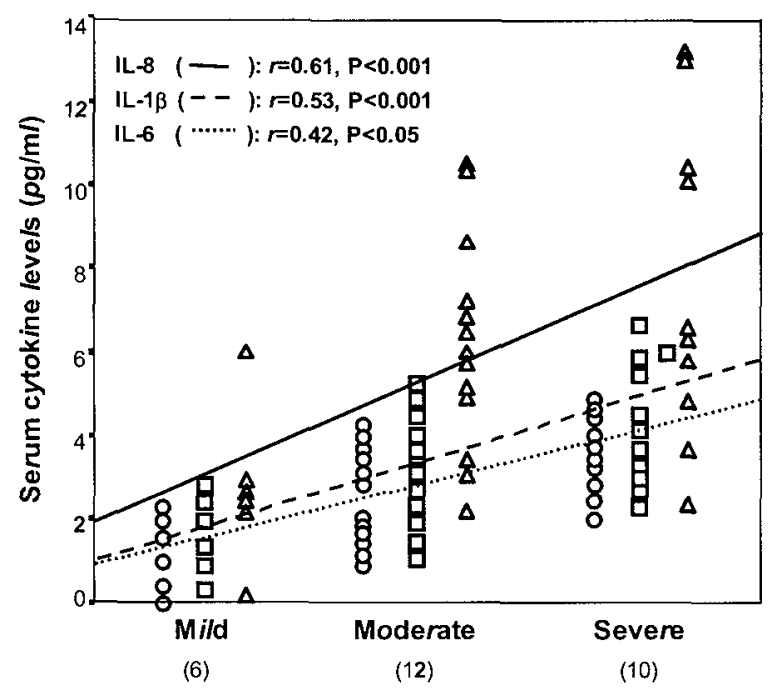

Corpus predominant atrophic gastritis

Figure 6.4. Correlation between circulating $\mathrm{IL}-1 \beta(\square), \mathrm{IL}-6(\mathrm{O}), \mathrm{IL}-8(\triangle)$, and the histological degree of corpus predominant atrophic gastritis. Numbers of subjects in parentheses.

Figure 6.5 shows the relationship between presence of non-H.pylori bacteria and of corpus predominant atrophic gastritis (left scale), cytokine levels (right scale), and duration of treatment with PPIs, in H.pylori-negative (A) and -positive (B) subjects on acid inhibition vs H.pylori-negative and -positive non-treated controls. Five subgroups of patients were distinguished according to the length of treatment they had undergone (from 'none' to '>36 months'). Age distribution was similar across the five subgroups of patients with or without H.pylori infection. In H.pylori-negative patients treated with PPIs, the prevalence of non-H.pylori bacteria increased with the longer duration of treatment; this was paralleled by a low prevalence of corpus atrophic gastritis (affecting 1 out of 44 [2.2\%] controls, and 1 out of 71 [1.4\%] patients on PPIs), and by nearly stable cytokine levels. In contrast, in H.pyloripositive patients treated with PPIs, the prevalence of non-H.pylori bacteria increased with the longer duration of treatment, and was paralleled by increasing prevalence of corpus atrophic gastritis (affecting 9 out of 10 [90\%] patients on PPIs longer than 36 months), and by increasing cytokine levels. Similar figures applied to both types of acid-suppressive therapy (PPIs and $\mathrm{H}_{2}$ RAs), but these reached statistical significance for the PPI group only, probably because of the small number of patients in the $\mathrm{H}_{2} \mathrm{RA}$ group (figure not shown). 


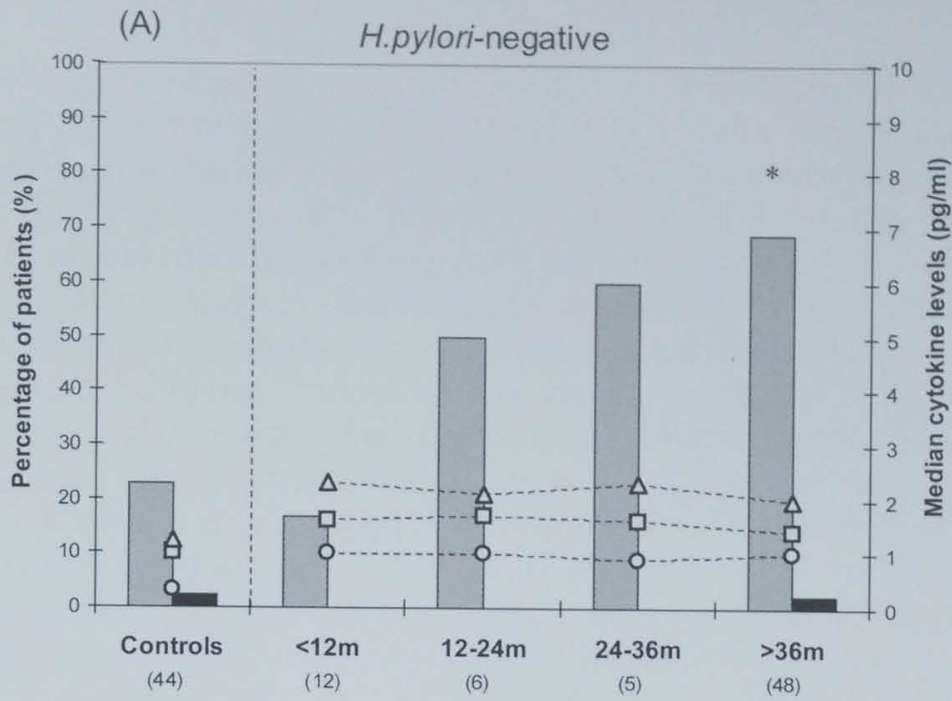

Duration of treatment with PPIs (months)

Higher prevalence of non-H.pylori bacteria $\left({ }^{*} P<0.01\right)$ vs controls and $v s$ patients treated $<12$ months No significant differences in the prevalence of CPAG or the cytokine levels.

(B)

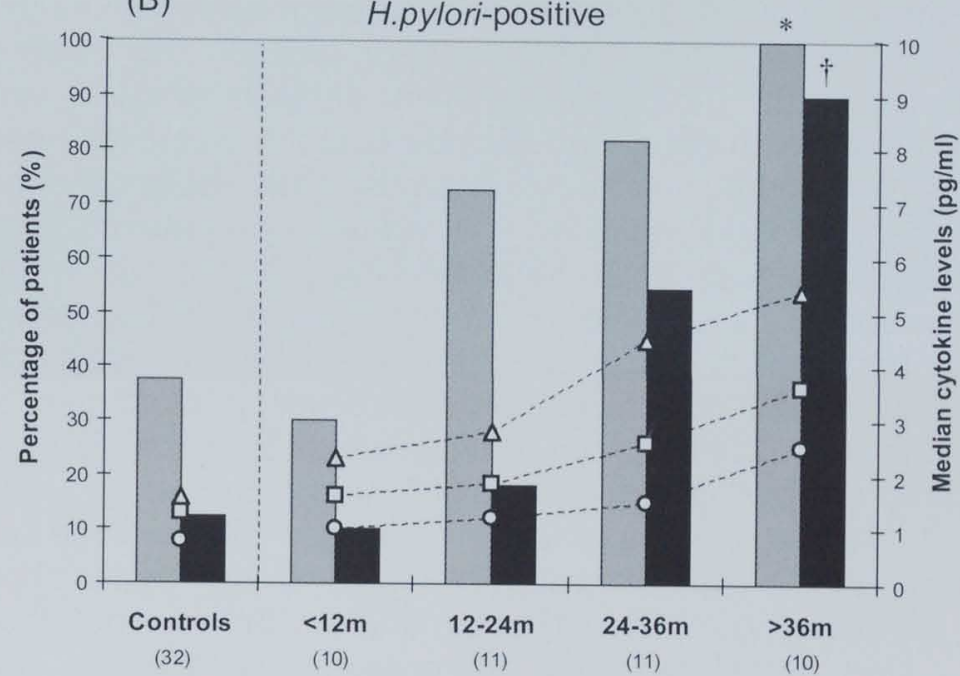

Duration of treatment with PPIs (months)

Higher prevalence of non-H.pylori bacteria ("P<0.01), higher prevalence of CPAG ( $\left.{ }^{\dagger} P<0.01\right)$ and higher cytokine levels ( $P<0.05$ for all cytokines) $v$ s controls and $v s$ patients treated $<12$ months.

Figure 6.5. Relationships between the presence of non-H.pylori bacteria ( $\square)$, of corpus predominant atrophic gastritis (-) (left scale), cytokine levels (right scale), and duration of treatment with PPIs in H.pylori-negative (A) and positive (B) subjects on acid inhibition vs H.pylori-negative and -positive non-treated controls. Median levels of circulating IL-1 $\beta(\square), ~ I L-6(O)$, and IL-8 $(\triangle)$ are represented. 


\section{Discussion}

This study addressed the question whether the double gastric infection with H.pylori and non-H.pylori bacteria - in patients treated with acidsuppressive medication - may result in an enhanced inflammatory response, contributing to an increased risk of developing atrophic gastritis. We have shown that: i) H.pylori-infected patients on long-term acid inhibition displayed three features: non-H.pylori bacterial growth, increased cytokine levels, and a high prevalence of corpus atrophic gastritis; ii) the development of atrophic gastritis during acidsuppressive therapy was associated with a simultaneous gastric infection with H.pylori and non-H.pylori bacteria; iii) the type of interaction between H.pylori and non-H.pylori bacteria was synergistic. Taken together, these findings indicate that the double gastric infection with H.pylori and non-H.pylori bacteria may play a major role in the development of atrophic gastritis.

\section{Intragastric bacteria, atrophic gastritis, and circulating cytokines}

Intragastric growth of non-H.pylori bacteria commonly occurs at elevated intragastric $\mathrm{pH}$, during administration of either $\mathrm{H}_{2} \mathrm{RAs}$ or PPIs $\mathrm{s}^{15}$ 18. Our results confirm and further extend this observation, demonstrating that, in H.pylori-positive subjects treated with acid inhibition, the overgrowth of non-H.pylori bacteria was accompanied by a high rate of corpus atrophic gastritis. This latter phenomenon, however, was not observed in the H.pylori-negative patients treated in a similar fashion. As such, it can be argued that infection with H.pylori is a prerequisite for the development of atrophic gastritis in this setting ${ }^{10,11}$.

An important finding of this study was that cytokine levels correlated with the anatomical distribution and the severity of chronic gastritis. Patients with antral predominant atrophic gastritis and those with diffuse non-atrophic gastritis displayed a slight - but significant - elevation in circulating cytokines compared to patients with normal mucosa. Noteworthy, the predominant involvement of the gastric body and fundus - representing a (twofold) larger anatomical area than the gastric antrum - was associated with the greatest elevation in circulating cytokines.

Our results also indicated that increasing age was associated with a higher risk of atrophic gastritis. Yet, its impact was marginal compared to that of the H.pylori infection, thereby supporting the contention that the development of atrophic gastritis is merely H.pylori-dependent than age-dependent ${ }^{33,34}$. Additionally, we found that infection with CagApositive H.pylori strains increases the risk of atrophic gastritis in the antrum but not in the corpus, a finding in line with recently published data $^{35}$. 


\section{Non-H.pylori bacteria: a cause or a consequence of atrophic gastritis?}

Two possible explanations can be suggested for the demonstrated link between non-H.pylori bacteria and atrophic gastritis:

1. Non-H.pylori bacterial overgrowth could be an epiphenomenon. Previous studies, including ours, have shown that in subjects infected with H.pylori, acid-suppressive therapy leads to a greater elevation in gastric juice $\mathrm{pH}^{8,36,37}$, predisposing to enhanced colonisation of the stomach by non-H.pylori bacterial species ${ }^{37,38}$. This observation has been confirmed in the present study. Furthermore, recent evidence linked genetic factors - such as polymorphisms in the genes encoding IL-1 - to an enhanced cytokine production in response to H.pylori infection, resulting in development of atrophic gastritis ${ }^{39}$, and subsequent overgrowth of non-H.pylori bacteria.

2. Non-H.pylori bacterial flora could be a co-factor in the development of atrophic gastritis. The following arguments come in favour of this hypothesis: First, as shown in Figure 6.5(B), H.pylori-positive patients on long-term PPIs were characterised by non-H.pylori bacterial growth and a high prevalence of corpus atrophic gastritis; this was in sharp contrast to the H.pylori-positive non-treated controls, who had similar demographic features, but a very low rate of corpus atrophic gastritis. Second, in H.pylori-positive patients treated with acid suppression, the presence of non-H.pylori bacteria preceded in time the development of corpus atrophic gastritis, a sequence supporting the hypothesis that bacterial infection was a causal factor rather than a consequence of atrophy. Third, the magnitude and ranking of cytokine increase were strongly concordant with the risk factors for atrophic gastritis emerging from the multiple regression analysis: patients harbouring the double infection had the highest cytokine levels paralleled by the highest risk of atrophic gastritis.

\section{Atrophic gastritis during acid-suppressive therapy: possible mechanism(s)}

It remains to be explained how the gastric co-infection with non-H.pylori bacteria could cause aggravation of the H.pylori-induced chronic gastritis. A study by Mowat et $a l^{38}$ has indicated that acid inhibition with omeprazole profoundly alters the intragastric milieu in subjects infected with H.pylori, leading to enhanced bacterial colonisation, elevated intragastric nitrites, and depletion of intragastric vitamin C. They 
suggested that such changes may facilitate the development of gastric mucosal atrophy. Additionally, it is possible that commensal bacteria and their by-products act as a persistent antigenic stimulus, that enhances and perpetuates the inflammatory response initiated by the H.pylori infection. In this sense, it is worthwhile to notice that the lipopolysaccharides (LPS) produced by gram-negative aerobic bacteria, such as Escherichia coli, may evoke substantially (>1000-fold) greater pro-inflammatory response than the H.pylori LPS ${ }^{40,41}$. The proinflammatory cytokines - mainly IL-1 $\beta$ - are potent inhibitors of the gastric parietal cell secretion ${ }^{42-44}$. As such, the increased production of IL-1 $\beta$ - driven by a double infection - may further promote the overgrowth of non-H.pylori bacteria, in a self-perpetuating process. Such explanations could underlie the observed synergistic interaction between H.pylori and non-H.pylori bacteria.

Figure 6.6 suggests a possible sequence of events leading to the accelerated development of atrophic gastritis during acid-suppressive therapy: In the presence of H.pylori infection, long-term acidsuppressive therapy leads to a corpus predominant pattern of gastritis or pangastritis ${ }^{9-11,45}$. Chronic hypochlorhydria and subsequent superinfection with non-H.pylori species may occur. This double gastric infection with H.pylori and non-H.pylori bacteria may then elicit a greater inflammatory response - as reflected by the elevated cytokines - leading to an accelerated development of atrophic gastritis.

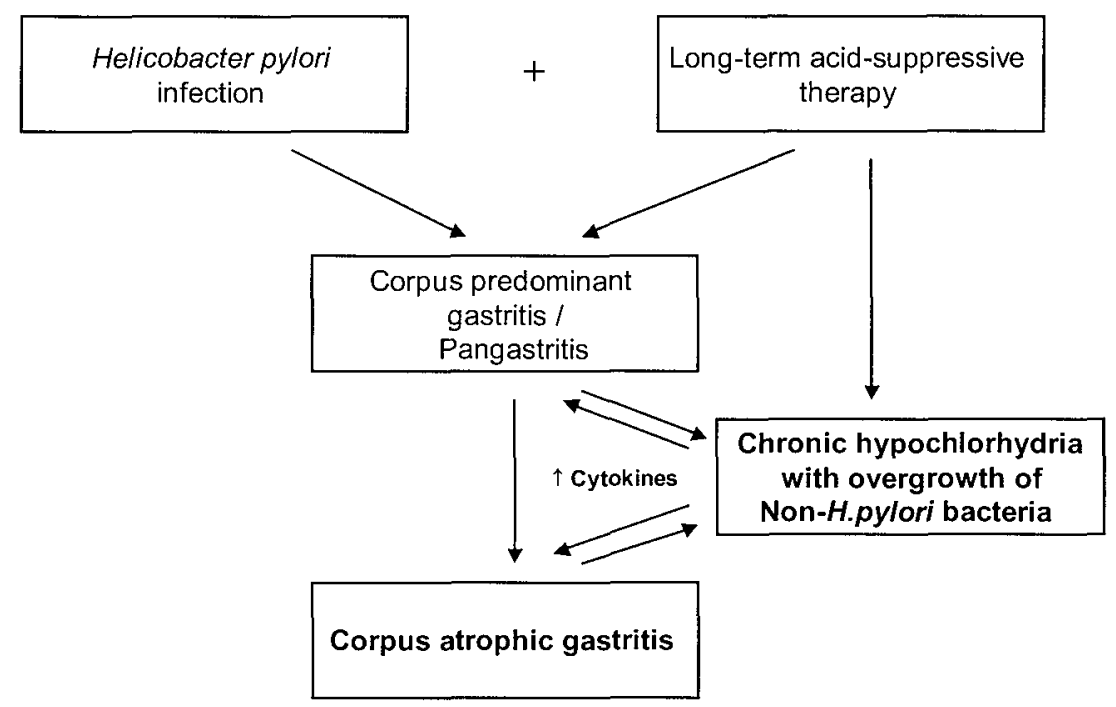

Figure 6.6. Development of atrophic gastritis during acid-suppressive therapy: a model. 


\section{Methodological aspects}

A few comments have to be made concerning methodological aspects of this study: First, the patients were consecutively recruited from a primary-care population, homogenous with regard to risk factors for the development of atrophic gastritis. Hence, the results presented and conclusions are representative for an everyday clinical situation. Second, this study was cross-sectional in design. Nevertheless, the role of the time factor in the development of atrophic gastritis could be estimated by patient histories and documentation concerning the length of antisecretory treatment, and by comparison with a sizeable control group. Further longitudinal studies are needed, however, to fully elucidate the time-course of gastric morphological changes caused by a double bacterial infection. Third, in the present study no special attention was paid to further identify the non-H.pylori bacterial species in the gastric mucosa, as this has been done in earlier publications by our own group ${ }^{24,26}$; we have consistently found a predominance of the oropharyngeal flora (e.g., Streptococci spp., Neisseria spp., and Corynebacterium spp.), but faecal-type bacteria (e.g., Escherichia coli, Klebsiella spp.) have been also isolated.

\section{General considerations and summary}

The present study may have clinical implications for the treatment of H.pylori-positive patients subjected to long-term acid-suppressive medication for acid-related disorders, especially for gastro-oesophageal reflux disease. H.pylori 'test-and-treat' strategy seems recommendable in this setting, in order to prevent the potential cumulative damage to the gastric mucosa due to a double bacterial infection. The non-H.pylori infection alone - unavoidable during gastric acid suppression - seems to do less harm to the gastric mucosa, and probably does not require major concern.

In summary, we have shown that in H.pylori-positive patients, the gastric co-infection with non-H.pylori bacteria - secondary to acid inhibition - seems to elicit a more vigorous inflammatory response. This may evolve to corpus atrophic gastritis, which is a precursor lesion for gastric cancer. The demonstrated relation between gastric acid inhibition, H.pylori, and non-H.pylori bacteria suggests that closer attention should be paid to the interaction between these factors when investigating the mechanisms underlying the development of atrophic gastritis and gastric cancer. 


\section{References}

1. Rauws EA, Langenberg W, Houthoff HJ, Zanen HC, Tytgat GNJ. Campylobacter pyloridis-associated gastritis: a prospective study of its prevalence and the effects of antibacterial and antiulcer treatment. Gastroenterology 1988;88:33-40.

2. Kuipers EJ, Uyterlinde AM, Peña AS, et al. Long-term sequelae of Helicobacter pylori gastritis. Lancet 1995;345:1525-8.

3. Correa P, Haenszel W, Cuello C, Tannenbaum S, Archer M. A model for gastric cancer epidemiology. Lancet 1975;2:58-60.

4. Sipponen G. Gastric cancer - a long-term consequence of Helicobacter pylori infection? Scand J Gastroenterol 1994;201:24-7.

5. Correa P. Human gastric carcinogenesis: a multistep and multifactorial process first American Society Award lecture on cancer epidemiology and prevention. Cancer Res 1992;52:6735-40.

6. Graham DY. Helicobacter pylori Infection in the Pathogenesis of Duodenal Ulcer and Gastric Cancer: A Model. Gastroenterology 1997;113:1983-91.

7. Lee A, Dixon MF, Danon SJ, et al. Local acid production and Helicobacter pylori: a unifying hypothesis of gastroduodenal disease. Eur J Gastroenterol Hepatol 1995;7:461-5.

8. El-Omar EM, Oien K, El-Nujumi A, et al. Helicobacter pylori infection and chronic gastric acid hyposecretion. Gastroenterology 1997;113(1):15-24.

9. Logan RP, Walker MM, Misiewicz JJ, Gummett PA, Karim QN, Baron JH. Changes in the intragastric distribution of Helicobacter pylori during treatment with omeprazole. Gut 1995;36:12-6.

10. Kuipers EJ, Lundell L, Klinkenberg-Knoll E, et al. Atrophic gastritis and Helicobacter pylori infection in patients with reflux esophagitis treated with omeprazole or fundoplication N Engl J Med 1996;334:1018-22.

11. Eissele R, Brunner G, Simon B, Solcia E, Arnold R. Gastric mucosa during treatment with lansoprazole: Helicobacter pylori is a risk factor for argyrophil cell hyperplasia. Gastroenterology 1997;112:707-17.

12. Lundell L, Miettinen $P$, Myrvold HE, et al. Lack of effect of acid suppression therapy on gastric atrophy. Gastroenterology 1999;117:319-26.

13. Suzuki M, Miura S, Suematsu M, et al. Helicobacter pylori-associated ammonia production enhances neutrophil-dependent gastric mucosal injury. Am J Physiol 1992;263:G719-25.

14. Stockbrügger RW, Cotton $P B$, Menon GG, et al. Pernicious anaemia, intragastric bacterial overgrowth, and possible consequences. Scand J Gastroenterol 1984;19:355-64.

15. Stockbrügger RW, Cotton PB, Eugenides N, Bartholomew BA, Hill MJ, Walters CL. Intragastric nitrites, nitrosamines and bacterial overgrowth during cimetidine treatment. Gut 1982;23:1048-54.

16. Sharma BK, Santana IA, Wood EC, et al. Intragastric bacterial activity and nitrosation before, during and after treatment with omeprazole. $\mathrm{Br}$ Med $\mathrm{J}$ 1984;289:717-9.

17. Verdú $E$, Viani $F$, Armstrong D, et al. Effect of omeprazole on intragastric bacterial counts, nitrates, and N-nitroso compounds. Gut 1994;35:455-60.

18. Thorens J, Froehlich F, Schwizer W, et al. Bacterial overgrowth during treatment with omeprazole compared to cimetidine: a prospective randomized double blind study. Gut 1996;39(1):54-9. 
19. Crabtree JE, Shallcross TM, Heatley RV, Wyatt JI. Mucosal tumour necrosis factor and interleukin-6 in patients with Helicobacter pylori associated gastritis. Gut 1991;32:1473-4.

20. Ando $T$, Kusugami $K$, Ohsuga $M$, et al. Interleukin-8 activity correlates with histological severity in Helicobacter pylori-associated antral gastritis. Am J Gastroenterol 1996;91:1150-6.

21. Gionchetti $P$, Vaira $D$, Campieri $M$, et al. Enhanced mucosal interleukin- 6 and interleukin-8 in Helicobacter pylori-positive dyspeptic patients. Am J Gastroenterol 1994;883-7.

22. Rath $\mathrm{HC}$, Herfarth $\mathrm{HH}$, Ikeda JS, et al. Normal luminal bacteria, especially Bacteroides species, mediate chronic colitis, gastritis, and arthritis in HLAB27/human beta2 microglobulin transgenic rats. J Clin Invest 1996;98:945-53.

23. Sartor RB, Rath HC, Sellon RK. Microbial factors in chronic intestinal inflammation. Curr Opin Gastroenterol 1996;12:327-33.

24. Jonkers $D$, Stobberingh $E$, de Bruïne A, Arends JW, Stockbrügger RW. Evaluation of immunohistochemistry for the detection of Helicobacter pylori in gastric mucosal biopsies. J Infection 1997;35(2):149-54.

25. Jonkers D, Gisbertz I, de Bruïne A, et al. Helicobacter pylori and non-Helicobacter pylori bacterial flora in gastric mucosal and tumour specimens of patients with primary gastric lymphoma. Eur J Clin Invest 1997;27:885-92.

26. Jonkers D, Houben P, Hameeteman W, et al. Differential features of gastric cancer patients, either Helicobacter pylori positive or Helicobacter pylori negative. Ital J Gastroenterol Hepatol 1999;31:836-41.

27. Price AB. The Sydney System: Histological division. J Gastroenterol Hepatol 1991;6:209-22.

28. Dixon M, Genta R, Yardley J, Correa P. Classification and grading of gastritis. The updated Sydney system. Am J Surg Pathol 1996;20:1161-81.

29. Genta RM. Recognizing atrophy: another step toward a classification of gastritis. Am J Surg Pathol 1996;20(S 1):S23-S30.

30. Andrew W, Wyatt JI, Dixon MF. Observer variation in the assessment of chronic gastritis according to the Sydney system. Histopathology 1994;25:317-22.

31. Kleinbaum DG, Kupper LL, Muller KE. Applied Regression Analysis and other multivariate methods. Boston: PBS-Kent publ. Co;1988.

32. Rothman K. Modern epidemiology. Boston: Little, Brown, 1986.

33. Correa P, Haenszel W, Cuello C, et al. Gastric precancerous process in a high-risk population: cohort follow-up. Cancer Res 1990;50:4737-40.

34. Valle J, Kekki M, Sipponen P, Ihamäki T, Siurala M. Long-term course and consequences of Helicobacter pylori gastritis. Scand J Gastroenterol 1996;31:54650 .

35. Oksanen A, Sipponen $\mathrm{P}$, Karttunen $\mathrm{R}$, et al. Atrophic gastritis and Helicobacter pylori infection in outpatients referred for gastroscopy. Gut 2000;46(4):460-3.

36. Verdú $\mathrm{E}$, Armstrong D, Fraser R, et al. Effect of Helicobacter pylori on intragastric $\mathrm{pH}$ during treatment with omeprazole. Gut 1995;36(4):539-43.

37. Sanduleanu $S$, Jonkers $D$, de Bruïne $A$, Hameeteman $W$, Stockbrügger RW. NonHelicobacter pylori bacterial flora during acid-suppressive therapy: differential findings in gastric juice and gastric mucosa. Aliment Pharmacol Ther 2001;15(3):379-88.

38. Mowat C, Williams C, Gillen D, et al. Omeprazole, Helicobacter pylori status and alterations in intragastric milieu facilitating bacterial N-nitrosation. Gastroenterology 2000;119:339-47.

39. El-Omar EM, Carrington $M$, Chow $W H$, et al. Interleukin-1 polymorphisms associated with increased risk of gastric cancer. Nature 2000; 404:398-402. 
40. Birkholz S, Knipp U, Nietzki C, et al. Immunological activity of lipopolysaccharide of Helicobacter pylori on human peripheral blood cells in comparison to lipopolysaccharides of other intestinal bacteria. FEMS Immunol Med Microbiol 1993;6:317-24.

41. Perez-Perez GI, Sheperd VI, Morrow JD, Blaser MJ. Activation of human THP-1 cells and rat bone marrow-derived macrophages by Helicobacter pylori lipopolysaccharide. Infect Immun 1995;63:1183-7.

42. Baume PE, Nicholls A, Baxter $\mathrm{CH}$. Inhibition of gastric acid secretion by a purified bacterial lipopolysaccharide. Nature 1967;215:59-60.

43. Kondo $S$, Shinomura $Y$, Kanayama $S$, et al. Interleukin-1 beta inhibits gastric histamine secretion and synthesis in the rat. Am J Physiol 1994; 1994;267:G96671.

44. Yasunaga $Y$, Shinomura $Y$, Kanayama $S$, et al. Mucosal interleukin-1 beta production and acid secretion in enlarged fold gastritis. Aliment Pharmacol Ther 1997;11:801-9.

45. McColl KE, El-Omar EM, Gillen D. Interactions between H.pylori infection, gastric acid secretion and anti-secretory therapy. Br Med Bull 1998;54:121-38. 


\section{Chapter 7}

\section{Prediction of atrophic body gastritis by serum markers}

S Sanduleanu, A de Bruïne, I Biemond, M Stridsberg,

D Jonkers, G Lundqvist, CBHW Lamers, W Hameeteman, RW Stockbrügger 


\section{Abstract}

\section{Background \& Aims}

Elevated serum gastrin and a low pepsinogen $A: C$ ratio are well-recognized markers of atrophic body gastritis. We have shown that the presence of body atrophy is also associated with elevated serum pro-inflammatory cytokines. This study tested the hypothesis that serum cytokines may have additional value to gastrin and pepsinogens in screening for atrophic body gastritis.

\section{Methods}

Two hundred and twenty-six consecutive patients were investigated on referral for upper gastrointestinal endoscopy: 150 were patients with gastro-oesophageal reflux disease, receiving acid inhibitory medication either with proton pump inhibitors $(n=113)$ or with histamine 2 -receptor antagonists $(n=37)$, and 76 were non-treated controls, who had normal endoscopic findings. Gastric mucosal biopsies were examined for histological evaluation of gastritis (Sydney classification). Serum samples were analysed for gastrin, chromogranin $A(\mathrm{CgA})$, and pepsinogens $A$ and $C$ by RIA, and for the interleukins (IL)$1 \beta, I L-6$, and IL-8 by ELISA.

\section{Results}

Subjects with atrophic body gastritis had significantly higher serum gastrin $(P<0.01)$ and serum CgA $(P<0.01)$ levels, and significantly lower pepsinogen $A: C$ ratios $(P<0.001)$ than those without atrophic body gastritis. Additionally, serum IL-1 $\beta, I L-6$, and IL-8 levels were significantly higher in subjects with than in those without atrophic body gastritis $(\mathrm{P}<0.0001$, for all cytokines). To optimise the detection of body atrophy we defined the atrophic body gastritis ( $A B G)$ index - that is the ratio between the simultaneously measured IL-8 and pepsinogen A:C levels. The area under the ROC curve for $A B G$ index was significantly greater than that for serum gastrin and for serum pepsinogen $A: C$ alone $(0.91 \pm 0.029$ vs $0.72 \pm 0.042$, and $v s \quad 0.83 \pm 0.031, P=0.018$ and $P=0.049)$. Using the $A B G$ index at a cut-off value of $1.8 \mathrm{pg} / \mathrm{ml}, 91 \%$ of the cases were classified correctly.

\section{Conclusions}

The simultaneous presence of a high $\mid L-8$ level and a low pepsinogen A:C ratio accurately predicts the atrophic body gastritis. Besides indicating presence of body atrophy, the $A B G$ index seems to reflect ongoing chronic active inflammation, which in long-term may promote the development of gastric cancer. 


\section{Introduction}

Chronic atrophic gastritis is a multifactorial condition, caused by the interplay between a genetic set-up, gastric bacterial infection, and environmental factors ${ }^{1-5}$. It is recognised that atrophic body gastritis increases the risk of developing non-cardia gastric cancer ${ }^{6-8}$. The identification of this lesion and its causes is therefore of considerable importance, making it possible to prevent this major cause of cancer death. Several studies addressed the potential of non-invasive, serologic screening for advanced atrophic body gastritis $(A B G)$; such cases would prompt further endoscopic and histologic investigation. Currently, serum gastrin and serum pepsinogens $\mathrm{A}$ and $\mathrm{C}$ are considered useful predictors of the morphologic and functional status of the gastric body mucosa ${ }^{9-11}$ : elevated serum gastrin and a low pepsinogen $A: C$ ratio commonly develop in the presence of body mucosal atrophy ${ }^{12-16}$. Additionally, serum chromogranin A (CgA) may increase, reflecting concomitant hyperfunction and proliferation of the fundic enterochromaffin-like $(E C L)$ cells ${ }^{17,18}$.

Recent results of our group have indicated that the presence and severity of the Helicobacter pylori (H.pylori)-induced atrophic body gastritis positively correlate to serum pro-inflammmatory cytokine levels ${ }^{19}$. However, no studies have been conducted, so far, to evaluate whether the assessment of serum cytokines in this context may provide additional information to the known predictors of atrophic body gastritis.

In a prospective cohort of dyspeptic subjects referred for upper gastrointestinal endoscopy to an open-access unit, we have compared the clinical utility of measuring serum pro-inflammatory cytokines: interleukin (IL)-1 $\beta, I L-6$, and IL-8, together with serum gastrin and serum pepsinogens in screening for atrophic body gastritis. As a result, we propose a simple and reliable screening test - the atrophic body gastritis $(A B G)$ index - to optimise the detection of this condition.

\section{Patients and methods}

Two hundred and twenty-six consecutive dyspeptic patients referred for upper gastrointestinal endoscopy to an open access unit (121 men and 105 women; mean age, 50.9 years, range, $19-79$ years) were investigated. The study population comprised 150 patients receiving acid-suppressive therapy - either histamine ${ }_{2}$-receptor antagonists $\left(\mathrm{H}_{2} \mathrm{RAs}, \mathrm{n}=37\right.$ ) or proton pump inhibitors (PPIs, $\left.n=113\right)$ - for gastrooesophageal reflux disease (GORD), and 76 dyspeptic subjects, 
comparable for age and gender, who did not receive acid-suppressive medication before referral, and who had normal endoscopic findings. All patients previously participated in a study investigating the relationship between intragastric bacteria and the development of atrophic gastritis during acid-suppressive therapy ${ }^{19}$. The following exclusion criteria were applied in all patients: present or past history of peptic ulcer disease; previous gastric surgery and/or vagotomy; prior H.pylori eradication therapy; treatment with antimicrobial agents, chronic NSAIDs use; any condition suspected or confirmed to influence the cytokine production, such as an acute infection in the previous 30 days; non-infectious inflammatory diseases, neoplasms, chronic liver or renal diseases, use of immuno-suppressive therapy. The study was approved by the Ethical Review Board of the University Hospital Maastricht, The Netherlands, and each subject gave informed consent before entering into the study.

Endoscopy was performed after an overnight fast, using a Pentax EG-2901 instrument. During endoscopy two antral biopsies $(2 \mathrm{~cm}$ proximal to the pylorus) and four corpus biopsies $(10 \mathrm{~cm}$ below the gastro-oesophageal junction, along the greater curvature) were sampled for histological examination. Fasting blood samples were obtained for the measurement of serum gastrin, $\mathrm{CgA}$, and pepsinogens, as well as of serum IL-1 $\beta, \mathrm{IL}-6$ and $\mathrm{IL}-8$. All blood samples were drawn between 9:00 am and 11:00 am.

\section{Serum assays}

Serum gastrin was measured by radioimmunoassay, using antibodies raised in rabbits against synthetic unsulphated human gastrin 2-17 covalently coupled to bovine serum albumin, as described previously ${ }^{20}$. The antibodies bind to all major forms of circulating gastrin, with almost equal potency. Serum CgA was measured by radioimmunoassay, using polyclonal antibodies raised in rabbits against a fragment of chromogranin A ( $\mathrm{CgA} \mathrm{116-439)} \mathrm{purified} \mathrm{from} \mathrm{the} \mathrm{urine} \mathrm{of} \mathrm{a} \mathrm{patient} \mathrm{with}$ a carcinoid tumour ${ }^{21,22}$. Serum pepsinogen $A$ and serum pepsinogen $C$ were measured by radioimmunoassay, using antibodies raised in goats against pepsinogens purified from human gastric resection specimens, as detailed elsewhere ${ }^{23,24}$. The upper limit of the normal range for serum gastrin was $<85 \mathrm{ng} / \mathrm{L}$, and for serum $\mathrm{CgA}$ was $<4 \mathrm{nmol} / \mathrm{L}$; the normal level for pepsinogen $A$ ranges from 19 to $95 \mu \mathrm{g} / \mathrm{L}$; for pepsinogen $C$, from 2 to $24 \mu \mathrm{g} / \mathrm{L}$; and for the pepsinogen A:C ratio, from 2.1 to 14.1 . The total assay variations with these methods are less than $10 \%$ for serum gastrin, less than $6.4 \%$ for serum $\mathrm{CgA}$, and less than $10 \%$ for both pepsinogen $A$ and $C$.

Serum IL-1 $\beta$, IL-6, and IL-8 were measured by ELISA (Cytoscreen ${ }^{\mathrm{TM}}$ human IL-1 $\beta$ ELISA kit, BioSource International, California, USA; IL-6 
ELISA kit IBL-Hamburg, Germany, and Genzyme IL-8 ELISA kit, Cambridge, USA). The detection limit for all these assays is $1 \mathrm{pg} / \mathrm{ml}$. Intra-assay variations of IL- $1 \beta, \mathrm{IL}-6$, and IL- 8 were less than $5 \%, 4.5 \%$, and $6.5 \%$, whereas the inter-assay variations were less than $7.5 \%$, $5.5 \%$, and $10.5 \%$, respectively. All samples from the same patient were analysed in duplicate and without knowledge of the patients' clinical and histologic data.

\section{Histology}

Serial sections $(4 \mu \mathrm{m})$ of formalin-fixed and paraffin embedded biopy specimens were stained with haematoxylin-eosin for general histological analysis. The histomorphologic status of the gastric body mucosa was assessed according to the Sydney classification ${ }^{25,26}$. The presence of active inflammation (i.e., the amount of neutrophilic cell infiltration), chronic inflammation (i.e., amount of mononuclear cell infiltration), gland atrophy (i.e., loss of oxyntic glands), and intestinal metaplasia in the gastric body mucosa was graded from 0 to $3(0$, absent; 1 , mild; 2 , moderate; 3 , severe changes). For the purpose of this study, atrophic body gastritis ( $A B G$ ) was defined as presence of oxyntic glands loss accompanied by at least mild chronic and/or active inflammation of the body mucosa.

In addition, specimens of body mucosa were immunostained for endocrine cells, using a monoclonal antibody against human $\mathrm{CgA}^{27}$. The status of the ECL cell population of the body mucosa was assessed according to the Solcia classification ${ }^{28}$; endocrine hyperplastic lesions were graded from 0 to 3 (0, absent; 1, diffuse hyperplasia; 2, linear hyperplasia; and 3 , micronodular hyperplasia). All biopsy specimens were reviewed by one experienced gastroenterological pathologist (A.B.) and by the main investigator (S.S.), without knowledge of the patients' clinical and serologic data. In the event of discordant results, the specimens were re-examined by a second pathologist and a joint diagnosis was made.

\section{Helicobacter pylori}

Determination of current H.pylori status was performed in both antral and body mucosa by modified Giemsa stain, immunohistochemistry (IMM), and culture. For the IMM, a purified polyclonal antiserum (DAKO B471, ITK diagnostics BV, Uithoorn, The Netherlands) in a dilution of $1: 100$ was used $^{29}$. Culture of gastric biopsies was performed on selective Campylobacter plates, under microaerophilic conditions. H.pylori was considered present when histopathology and/or culture were positive. 


\section{Statistical analysis}

Differences in dichotomous variables were examined using the $\chi^{2}$ test or Fisher's exact test when necessary. Differences in continuous variables were examined using the Kruskal-Wallis test for multiple comparisons and the Mann-Whitney $U$ test for two group comparisons. Correlations were performed with the Spearman rank test. Receiver operating characteristics (ROC) curves and the respective areas under the curves (AUC) were computed for each potential predictor of atrophic body gastritis. The magnitude of the AUC provides information about the test accuracy. All combinations between serum cytokines, gastrin, and pepsinogens have been tested in an attempt to optimize the diagnostic accuracy for atrophic body gastritis. As such, we calculated the ratio between IL-8 and pepsinogen $A: C$, which was defined as the atrophic body gastritis index $(A B G$ index $=I L-8 /$ pepsinogen $A: C)$. Nonparametric estimates of the areas under the ROC curves and their standard errors (SE) were applied ${ }^{30}$. A procedure involving paired data was used to compare areas under the ROC curves ${ }^{31}$. The best cut-off was considered as the value that maximized the likelihood ratio (LR) obtained using the following formula: $L R=$ (probability of true positive + probability of true negative) / (probability of false positive + probability of false negative $)^{32}$. Using these cut-off values, the sensitivity, specificity, and the diagnostic accuracy (percentage of correctly predicted results) were also assessed. All statistical evaluations were performed running the SPSS 10.0, for Windows. Two-sided P-values $<0.05$ were assumed to indicate statistical significance.

\section{Results}

Table 7.1 describes the histomorphologic status of the gastric body mucosa in subjects across the three subgroups: non-treated controls, $\mathrm{H}_{2} \mathrm{RA}$ group, and PPI group. Overall, H.pylori-positive subjects had significantly higher prevalence of atrophic body gastritis (38 out of 89 [42.7\%] vs 4 out of 137 [2.9\%], P<0.0001), and of ECL cell hyperplasia (21 out of 89 [23.6\%] vs 6 out of 137 [4.4\%], $P<0.0001$ ) than the H.pylori-negative subjects. In the 42 subjects with atrophic body gastritis, gland atrophy was accompanied by chronic inflammation in all cases (10 mild; 22 moderate; 10 severe), and/or active inflammation in 22 cases ( 16 mild; 4 moderate; 2 severe). 


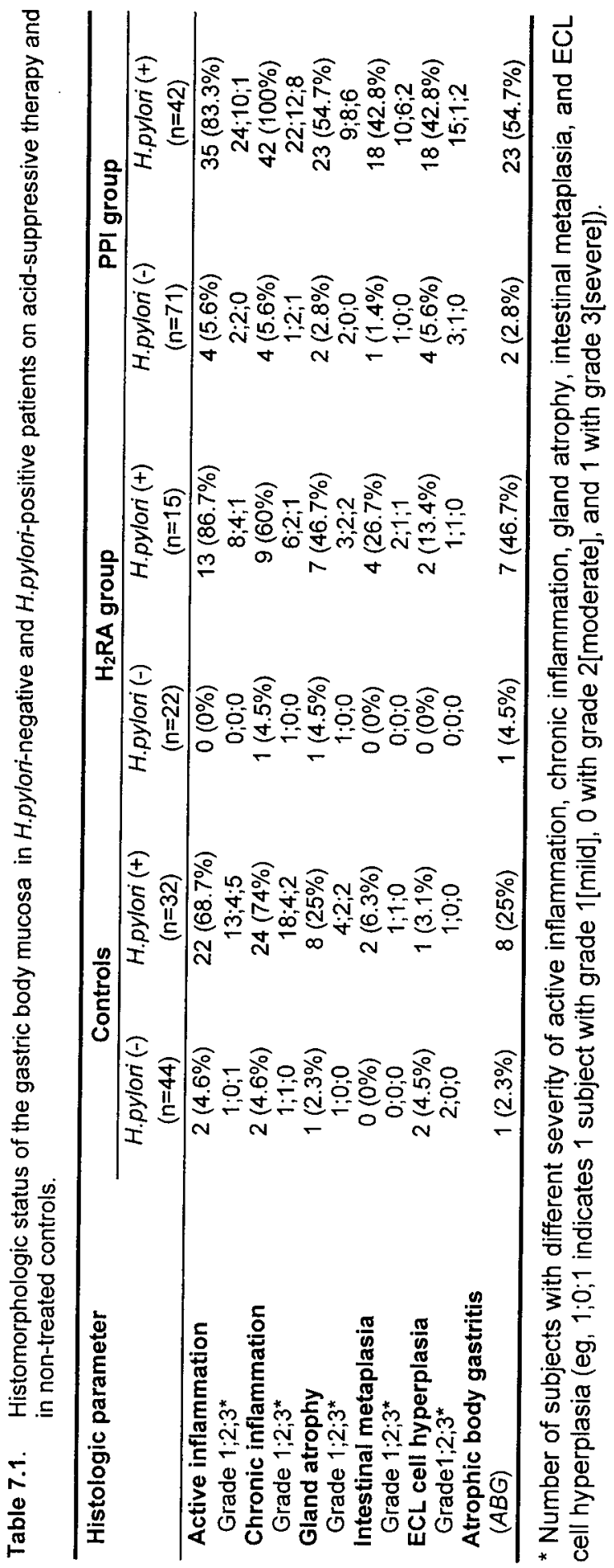


As shown in Figure 7.1, among the three subgroups, subjects with atrophic body gastritis yielded significantly higher serum levels of IL-1 $\beta$ (A), IL-6 (B), and especially IL-8 (C) than those without atrophic body gastritis. Additionally, as shown in Table 7.2, subjects with atrophic body gastritis had higher serum gastrin, serum $\mathrm{CgA}$, and serum pepsinogens $A$ and $C$ levels than those without body mucosal atrophy. Conversely, serum pepsinogen $\mathrm{A}: \mathrm{C}$ ratios were significantly lower in subjects with than in those without atrophic body gastritis.

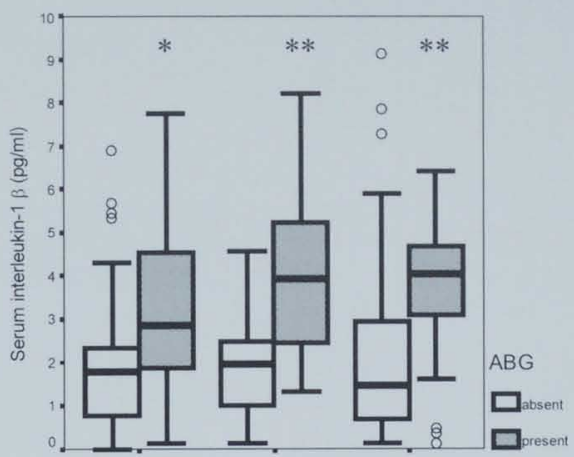

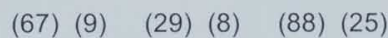

Controls $\mathrm{H}_{2} \mathrm{RA}$ group PPI group

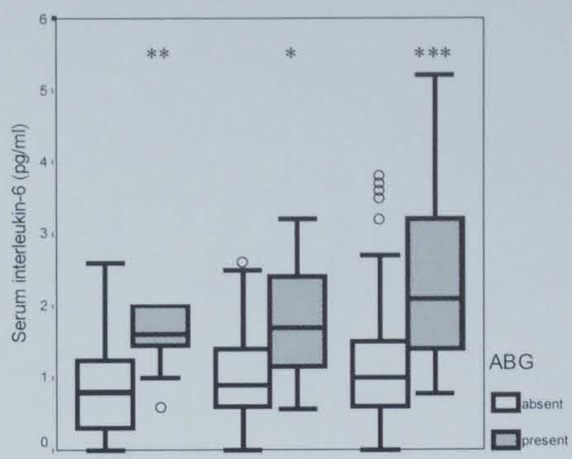

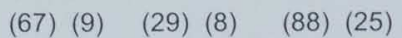

Controls $\mathrm{H}_{2} \mathrm{RA}$ group PPI group

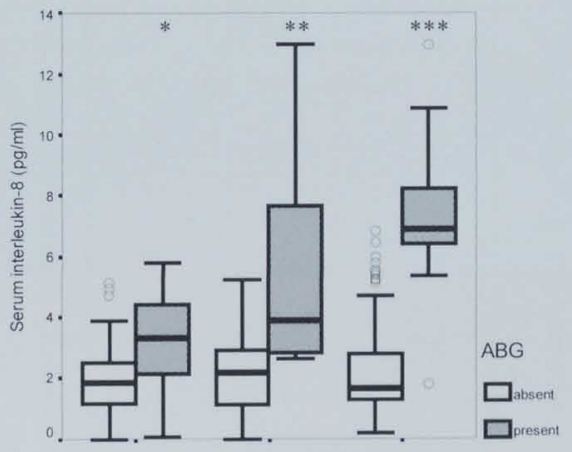

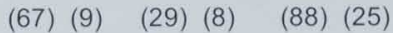

Controls $\mathrm{H}_{2} \mathrm{RA}$ group PPI group

Figure 7.1. Serum IL-1 $\beta$ (A), IL-6 (B), and IL-8 (C) levels in subjects with and without atrophic body gastritis (ABG). The $50^{\text {th }}$ percentile (median) is indicated with a line in the box, the end of the box indicates the $25^{\text {th }}$ and $75^{\text {th }}$ percentile, and the $10^{\text {th }}$ and $90^{\text {th }}$ percentile are indicated with error bars. The open circles indicate outliers, which are not extreme values. ${ }^{*} \mathrm{P}<0.05$ and ${ }^{* *} P<0.01$ and ${ }^{* * *} P<0.0001$ vs subjects withut atrophic body gastritis 


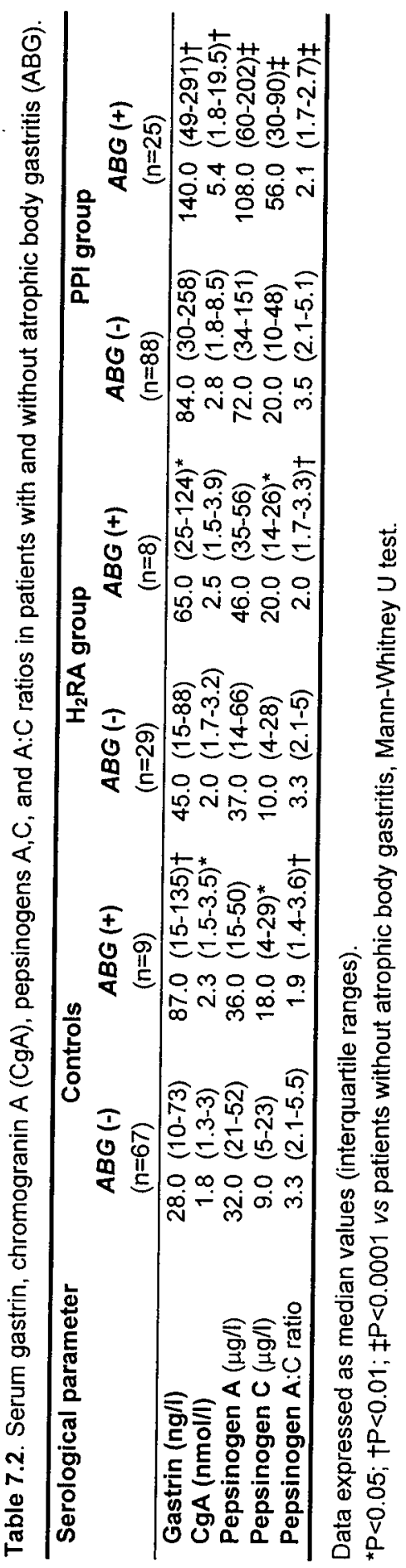


In the entire series, positive correlations were found between serum gastrin and serum IL-1 $\beta(r=0.38, P<0.001)$, IL-6 ( $r=0.42, P<0.001)$, and IL-8 $(r=0.50, P<0.001)$ levels. Conversely, negative correlations were found between serum pepsinogen $A: C$ ratios, and serum IL-1 $\beta(r=-0.49$, $P<0.001)$, IL-6 ( $r=-0.45, P<0.0001)$, and especially $I L-8$ ( $r=-0.65$, $\mathrm{P}<0.0001$ ) (Figure 7.2). Additionally, serum $\mathrm{CgA}$ positively correlated with serum cytokine levels ( $P<0.01$ for all three cytokines). Furthermore, the histological degree of atrophic body gastritis correlated positively to serum gastrin $(r=0.62, P<0.001), \mathrm{CgA}(r=0.50, P<0.001)$ and $\mathrm{IL}-8$ $(r=0.52, \quad P<0.001)$ levels, and correlated negatively to serum pepsinogens $A: C$ ratios $(r=-0.69, P<0.0001)$.

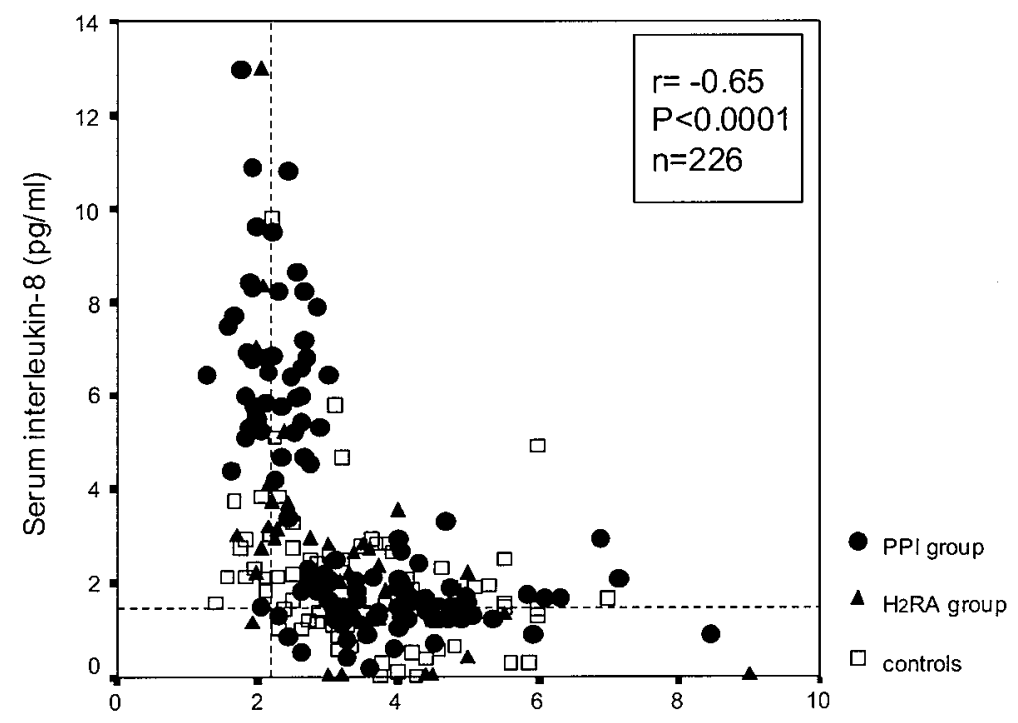

Pepsinogen A:C ratio

Figure 7.2. Correlation between serum $\mathrm{IL}-8$ levels and serum pepsinogen $A: C$ ratios in 226 subjects $(r=-0.65, P<0.0001)$.

Among the three pro-inflammatory cytokines, serum IL-8 correlated best with the presence and histological degree of body mucosal atrophy. As such, in an attempt to optimize the diagnostic accuracy for atrophic body gastritis, we have defined the $A B G$ index, calculated as the ratio between IL-8 and pepsinogen A:C.

Figure 7.3 illustrates the ROC curves for gastrin alone, pepsinogen $A: C$ ratio alone, combined gastrin and pepsinogen $A: C$ ratio, and finally for the $A B G$ index, in the prediction of atrophic body gastritis. The values of the AUCs $( \pm S E)$ corresponding to each potential predictor of this condition are listed in Table 7.3. As serum gastrin and serum pepsinogens could be influenced by concomitant use of acid- 
suppressive medication ${ }^{17,18,24}$, the patients on acid suppression and the non-treated controls were analysed separately. However, the distribution of the ROC curves was similar in patients on acid suppression and in non-treated controls (Table 7.3). Thus, combining all subjects, we found that $A B G$ index displayed the greatest AUC $(0.910 \pm 0.029)$; this was significantly greater than that of serum gastrin alone $(0.721 \pm 0.042, P=0.018)$, serum pepsinogen $A: C$ ratio alone $(0.830 \pm 0.031, P=0.049)$, and also than the combined use of gastrin and pepsinogen $A: C$ ratio $(0.806 \pm 0.035, P=0.046)$.

\section{ROC curves}

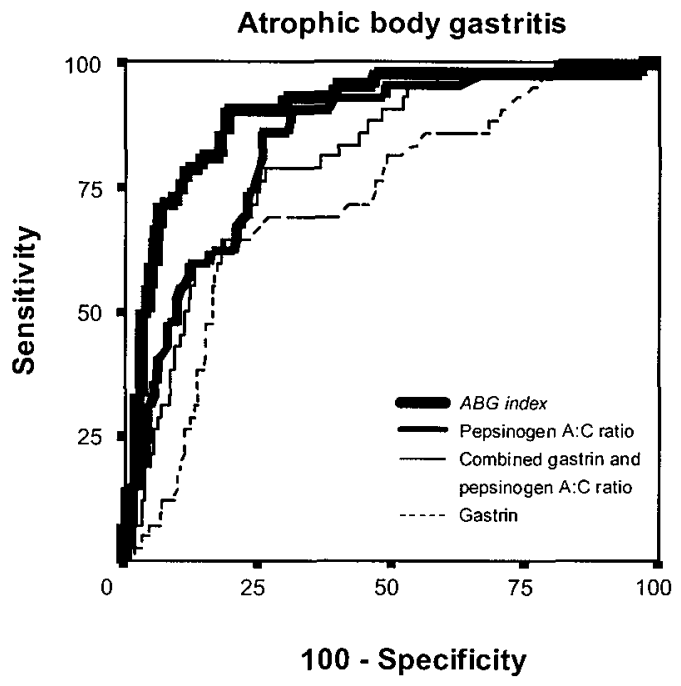

Figure 7.3 Receiver operating characteristics (ROC) curves for the prediction of atrophic body gastritis in 226 subjects. The area under the curve (AUC) for the $A B G$-index was significantly greater than that of serum gastrin alone $(P=0.018)$, serum pepsinogen $A: C$ ratio $(P=0.049)$, and than the combined use of serum gastrin and pepsinogen $A: C$ ratio $(P=0.046)$.

Table 7.3.The areas under the curves (AUC) and the standard errors (SE) for serum markers of atrophic body gastritis.

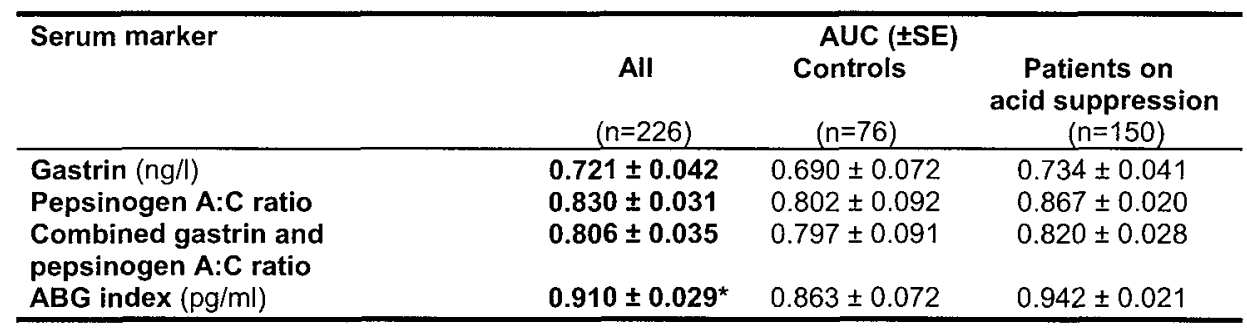

*The AUC for the $A B G$ index was greater than for gastrin $(P=0.018)$, pepsinogen $A: C$ ratio $(P=0.049)$, and the combined gastrin and pepsinogen $A: C$ ratio $(P=0.046)$. 
Table 7.4 shows the best cut-off values and the corresponding performance characteristics for the above-mentioned tests. The best cut-off values for detection of atrophic body gastritis were: $116 \mathrm{ng} / \mathrm{L}$, for serum gastrin; 2.5 , for serum pepsinogen $A: C$ ratio; and $1.8 \mathrm{pg} / \mathrm{ml}$, for the $A B G$ index. Using serum gastrin (cut-off value: $116 \mathrm{ng} / \mathrm{L}$ ), 179 out of $226(79 \%)$ cases were classified correctly. The corresponding figure for serum pepsinogen A:C ratio (cut-off value: 2.5) was 200 out of 226 $(88 \%)$ cases. The best test accuracy was achieved using the $\boldsymbol{A B G}$ index (cut-off value: $1.8 \mathrm{pg} / \mathrm{ml}$ ): 205 out of $226(91 \%)$ cases were classified correctly. In the remaining $21(9 \%)$ cases, discrepancy was found between the biochemical ( $A B G$ index) and histological evidence of atrophic body gastritis. Among the $11(5 \%)$ cases with a negative biochemical test and positive histology, all but one displayed chronic inflammation of the body mucosa ( 3 mild, 5 moderate, and 3 severe); additionally, 8 displayed gland atrophy ( 8 mild, and only 2 moderate). Among the $10(4 \%)$ cases with a positive biochemical test and negative histology, all displayed chronic inflammation of the body mucosa (1 mild, 5 moderate, and 4 severe).

Table 7.4. The cut-off values and test performance characteristics for serum gastrin, pepsinogen $A: C$ ratio, and the $A B G$ index in the detection of atrophic body gastritis.

\begin{tabular}{lcccccc}
\hline Serum marker & $\begin{array}{c}\text { Cut-off } \\
\text { value }\end{array}$ & $\begin{array}{c}\text { Sensitivity } \\
(\%)\end{array}$ & $\begin{array}{c}\text { Specificity } \\
(\%)\end{array}$ & $\begin{array}{c}\text { PPV } \\
(\%)\end{array}$ & $\begin{array}{c}\text { NPV } \\
(\%)\end{array}$ & $\begin{array}{c}\text { Accuracy } \\
(\%)\end{array}$ \\
\hline Gastrin $(\mathrm{ng} / \mathrm{l})$ & 116 & 60 & 83 & 46 & 90 & 79 \\
Pepsinogen A:C ratio & 2.5 & 62 & 95 & 72 & 92 & 88 \\
ABG index $(\mathrm{pg} / \mathrm{ml})$ & 1.8 & 74 & 94 & 76 & 94 & 91 \\
\hline
\end{tabular}

\section{Discussion}

This study confirms previously reported data showing that a high serum gastrin and a low pepsinogen $A: C$ ratio are good predictors for the presence and severity of atrophic body gastritis ${ }^{9,11,13-15}$. It is, however, the first study to indicate that the measurement of serum proinflammatory cytokines may provide additional information on the histomorphologic status of the gastric body mucosa, as compared to the aforementioned biochemical tests. We have shown that the simultaneous presence of a high IL-8 level and a low pepsinogen A:C ratio - defined by us as the $A B G$ index - yielded the best test accuracy in predicting atrophic body gastritis. At a cut-off value of $1.8 \mathrm{pg} / \mathrm{ml}$, the proportion of well-predicted cases was $91 \%$. Importantly, as illustrated by the ROC curves, the $A B G$ index performed significantly better than serum gastrin alone, serum pepsinogen $A: C$ ratio alone, and than the 
combined use of gastrin and pepsinogen $A: C$ ratio. The calculation of such index is therefore appealing for several reasons:

1. From a diagnostic viewpoint, a simple and reliable test to detect atrophic body gastritis may be useful in a community setting, for screening populations exposed to risk factors for a more rapid development of atrophic gastritis. In recent years, much attention and research effort have emerged to identify these risk groups. As such, compelling evidence now indicates that first-degree relatives of patients with gastric cancer carry an increased risk of developing atrophic body gastritis in the presence of H.pylori infection ${ }^{33}$; genetic traits, such as polymorphisms of the genes encoding IL-1 $\beta$ probably underlie such development ${ }^{34}$. Also, long-standing acid suppressivetherapy in H.pylori-positive subjects increases the risk of atrophic body gastritis ${ }^{35-38}$; the simultaneous gastric infection with nonH.pylori bacterial species may be a co-factor in this process ${ }^{19,39,40}$. Whatever the risk factors would be, in these subjects, serological testing for atrophic body gastritis may be an aid in clinical decision making, orientating further referral for endoscopic and histologic examination.

2. From a scientific viewpoint, the $A B G$ index provides a better insight on the morphologic status of the body mucosa. In interpreting its significance, it should be borne in mind that a low pepsinogen $\mathrm{A}: \mathrm{C}$ ratio reflects 'established' glandular loss in the body mucosa, whilst a simultaneous high IL-8 level more probably reflects ongoing chronic active inflammation, which in long-term may facilitate the development of gastric cancer.

Several studies addressed the issue of serologic screening for atrophic body gastritis, as this condition carries an increased risk for the development of gastric cancer ${ }^{7,8}$. In an earlier report of 171 first-degree relatives of patients with pernicious anaemia, Varis et al. ${ }^{9}$ found that a high serum gastrin and a low serum pepsinogen A were equally specific $(97 \%)$ for severe atrophic body gastritis, but the sensitivity of pepsinogen A was greater than that of gastrin (91\% vs $83 \%)$. Furthermore, they found a specificity of $100 \%$ for the combined use of gastrin and pepsinogen $A$. In a study looking at the prevalence of atrophic gastritis in 207 consecutive Scandinavian patients, Oksanen et al. ${ }^{41}$ found test specificities for serum gastrin (cut-off $>111 \mathrm{pg} / \mathrm{ml}$ ) of $96 \%$, and for serum pepsinogen A (cut-off $<28 \mu \mathrm{g} / \mathrm{L}$ ) of $99 \%$, whilst the test sensitivities were $75 \%$ and $81 \%$, respectively. In a recent literature survey comparing the test characteristics of various screening methods for atrophic body gastritis, Ley et $a .^{42}$ observed a wide variation in this 
respect. They suggested that this could be due to differences in populations studied (e.g. in selection criteria, nature and array of the underlying risk factors, as well as dissent on definition of atrophic gastritis, and very different cut-off values of the tests applied. In a clinical trial conducted by their own group in Chiapas (Mexico) on 205 healthy volunteers aged $40+$ years, they found that serum pepsinogen $A: C$ ratio (cut-off $<2.5$ ) had a good specificity $(95.7 \%$ ), but a poor sensitivity $(13.7 \%)$ for the detection of body atrophy ${ }^{42}$.

Taken together, these findings and our own data indicate that, in general, serum markers of atrophic body gastritis are useful for 'ruling out' this condition (good negative predictive value), although their value for 'ruling in' the diagnosis is merely moderate (moderate positive predictive value). This observation is probably not surprising and two eventually confounding situations will be further discussed: First, a positive test is more likely to occur in the presence of severe atrophy; hence, a negative biochemical test may simply imply less advanced atrophic changes. Second, it is known that in the presence of chronic active inflammation, the detection and gradation of gland atrophy may be overestimated ${ }^{43,44}$; hence, signs of atrophy will be detected in spite of a negative biochemical test. Such explanations could account for the $5 \%$ of the cases in our series, having a 'normal $A B G$ index', despite positive histology. Conversely, $4 \%$ of the cases had a high $A B G$ index, despite negative histology. A possible explanation for this latter discrepancy is that, chronic inflammation involves pro-inflammatory cytokines at an early stage; this cytokine activation may then result in progression of inflammation to gland atrophy, and eventually changes in serum gastrin and pepsinogens profiles. In this sense, a clear advantage emerges from using the $A B G$ index: the likelihood to detect early (pre-atrophic) changes of the gastric body mucosa.

In summary, this study has shown that the measurement of serum pro-inflammatory cytokines, especially $\mathrm{IL}-8$, provides insights on the histomorphologic status of the gastric body mucosa, being a useful complement to the known predictors, gastrin and pepsinogen $\mathrm{A}: \mathrm{C}$ ratio. Furthermore, the $A B G$ index was a better predictor of atrophic body gastritis than serum gastrin and serum pepsinogen $A: C$ ratio alone. We therefore recommend the $\boldsymbol{A B G}$ index as a reliable, non-invasive screening test for atrophic body gastritis in large-scale population studies. 


\section{References}

1. Strickland RG, Mackay IR. A reappraisal of the nature and significance of chronic atrophic gastritis. Dig Dis Sci 1973;18:426-40.

2. Stockbrügger RW, Angervall L, Lundqvist $G$. Serum gastrin and atrophic gastritis in achlorhydric patients with and without pernicious anaemia. Scand $\mathrm{J}$ Gastroenterol 1976;11(7):713-9.

3. Kuipers EJ, Uyterlinde AM, Peña AS, Roosendaal R, Pals G, Nelis GF, Festen HP, et al. Long term sequelae of Helicobacter pylori gastritis. Lancet 1995;345:1525-8.

4. Kuipers EJ, Klinkenberg-Knol EC, Vandenbroucke-Grauls CMJ, et al. Role of Helicobacter pylori in the pathogenesis of atrophic gastritis. Scand J Gastroenterol 1997;32 (S 223):28-34.

5. Houben GM, Stockbrügger RW. Bacteria in the aetio-pathogenesis of gastric cancer: a review. Scand J Gastroenterol 1995;30(S 212):13-8.

6. Correa P, Haenszel W, Cuello C, Tannenbaum S, Archer M. A model for gastric cancer epidemiology. Lancet 1975;2:58-60.

7. Sipponen P, Kekki M, Haapakoski J, Ihamäki T, Siurala M. Gastric cancer risk in chronic atrophic gastritis: statistical calculations of cross-sectional data. Int J Cancer 1985;35:173-7.

8. Tatsuta $M$, lishi $H$, Kakaizumi $A$, et al. Fundal atrophic gastritis as a risk factor for gastric cancer. Int J Cancer 1993;53:70-4.

9. Varis K, Samloff IM, Ihamäki $T$, et al. An appraisal of tests for severe atrophic gastritis in relatives of patients with pernicious anemia. Am J Dig Dis 1979;32 (suppl 223):28-34.

10. Stockbrügger RW, Larsson LI, Lundqvist G, Angervall L. Antral gastrin cells and serum gastrin in achlorhydria. Scand J Gastroenterol 1977;12(2):209-13.

11. Samloff IM, Varis K, Ihamäki T, Siurala M, Rotter JI. Relationships among serum pepsinogen I, serum pepsinogen II, and gastric mucosal histology. A study in relatives of patients with pernicious anemia. Gastroenterology 1982;83:204-9.

12. Blins $M$, Burgers $P I C J$, Selbach SGM, van Wettum TB, Lamers CBHW, van Tongeren JHM. The relation between basal gastric $\mathrm{pH}$ and serum gastrin. Digestion 1982;23: 271-3.

13. Borch $K$, Axelsson $C K$, Halgreen $H$, Damkjaer Nielsen M, Ledin $T$, et al. The ratio of pepsinogen $A$ to pepsinogen $\mathrm{C}$ : a sensitive test for atrophic gastritis. Scand $\mathrm{J}$ Gastroenterol 1989;24:870-6.

14. Westerveld BD, Pals G, Lamers CBHW, Defize J, Pronk JC, Frantz RR, et al. Clinical significance of pepsinogen $A$ isoenzymogens, serum pepsinogen $A$ and pepsinogen $C$ levels, and serum gastrin levels. Cancer 1987;59:952-8.

15. Knight T, Wyatt J, Wilson A, Greaves S, Newell D, Hengels K, et al. Helicobacter pylori gastritis and serum pepsinogen levels in a healthy population: development of a biomarker strategy for gastric atrophy in high risk groups. $\mathrm{Br} \mathrm{J}$ Cancer 1996;73(6):819-24.

16. Schlemper RJ, van der Werf SDJ, Vandenbroucke JP, Biemond I, Lamers CBHW. Seroepidemiology of gastritis in Japanese and Dutch working populations: evidence for the development of atrophic gastritis that is not related to Helicobacter pylori. Gut 1995;37:199-204.

17. Waldum HL, Arnestad JS, Brenna E, et al. Marked increase in acid secretory capacity after omeprazole treatment. Gut 1996;39:649-53. 
18. Sanduleanu $S$, Stridsberg $M$, Jonkers $D$, Hameeteman $W$, Biemond I, Lamers $\mathrm{CBHW}$, et al. Serum gastrin and chromogranin A during medium- and long-term acid suppressive therapy: a case-control study. Aliment Pharmacol Ther 1999;13:145-53.

19. Sanduleanu S, de Bruïne A, Jonkers D, Hameeteman W, Stockbrügger RW. Double gastric infection with Helicobacter pylori and non-Helicobacter pylori bacteria during acid-suppressive therapy: increase of pro-inflammatory cytokines and development of atrophic gastritis. Aliment Pharmacol Ther 2001; in press.

20. Lamers $\mathrm{CBHW}$, van Tongeren $\mathrm{JH}$. Comparative study of the value of the calcium, secretin, and meal-stimulated increase in serum gastrin to the diagnosis of the Zollinger-Ellison syndrome. Gut 1977; 18(2):128-35.

21. Stridsberg G, Hellman U, Wilander E, et al. Fragments of chromogranin A are present in the urine of patients with carcinoid tumours. J Endocrinol 1993;139:32937.

22. Stridsberg $M$, Öberg $K$, Li Q, et al. Measurement of chromogranin $A$, chromogranin B (secretogranin I), chromogranin C (secretogranin II) and pancreastatin in plasma and urine of patients with carcinoid tumours. J Endocrinol 1995;144:49-59.

23. Biemond I, Jansen JBMJ, Crobach LFSJ, Kreuning J, Lamers CBHW. Radioimmunoassay of human pepsinogen $A$ and pepsinogen $C$. Eur $\mathrm{J}$ Clin Chem Clin Biochem 1989;27:19-25.

24. Biemond 1, Kreuning J, Jansen JBMJ, Lamers CBHW. Diagnostic value of serum pepsinogen $C$ in patients with raised serum concentrations of pepsinogen $A$. Gut 1993;34:1315-8.

25. Price $A B$. The Sydney System: histological division. J Gastroenterol Hepatol 1991;6:209-22.

26. Dixon M, Genta R, Yardley J, Correa P. Classification and grading of gastritis. The updated Sydney system. Am J Surg Pathol 1996;20:1161-81.

27. Lloyd RV, Wilson BS. Specific endocrine tissue defined by a monoclonal antibody. Science 1983;222:628-30.

28. Solcia E, Bordi C, Creutzfeldt W, et al. Histopathological classification of nonantral gastric endocrine growths in man. Digestion 1988;41:185-200.

29. Jonkers D, Stobberingh E, de Bruïne A, Arends JW, Stockbrügger RW. Evaluation of immunohistochemistry for the detection of Helicobacter pylori in gastric mucosal biopsies. J Infect 1997;35:149-54.

30. Hanley JA, McNeil BJ. The meaning and use of the area under a receiver operating characteristic (ROC) curve. Radiology 1982;143:29-36.

31. Hanley JA, McNeil BJ. A method of comparing the areas under receiver operating characteristics curves derived from the same cases. Radiology 1983;148:839-43.

32. Lusted LB. Decision-making studies in patient management. $\mathrm{N}$ Engl $\mathrm{J}$ Med 1971;284:416-24.

33. El-Omar EM, Oien K, Murray LS, El-Nujumi A, Wirz A, Gillen D, et al. Increased prevalence of precancerous changes in relatives of gastric cancer patients: critical role of H.pylori. Gastroenterology 2000;118:22-30.

34. El-Omar EM, Carrington M, Chow WH, McColl KEL, Bream JH, Young HA, et al. Interleukin-1 polymorphisms associated with increased risk of gastric cancer. Nature 2000;404:398-402.

35. Logan RP, Walker MM, Misiewicz JJ, Gummett PA, Karim QN, Baron JH. Changes in the intragastric distribution of Helicobacter pylori during treatment with omeprazole. Gut 1995;36:12-6.

36. Kuipers EJ, Lundell L, Klinkenberg-Knoll $E$, et al. Atrophic gastritis and Helicobacter pylori infection in patients with reflux esophagitis treated with omeprazole or fundoplication N Engl J Med 1996;334:1018-22. 
37. Eissele R, Brunner G, Simon B, Solcia E, Arnold R. Gastric mucosa during treatment with lansoprazole: Helicobacter pylori is a risk factor for argyrophil cell hyperplasia. Gastroenterology 1997;112:707-17.

38. Lundell L, Miettinen P, Myrvold HE, et al. Lack of effect of acid suppression therapy on gastric atrophy. Gastroenterology 1999;117:319-26.

39. Sanduleanu $S$, Jonkers $D$, de Bruine A, Hameeteman W, Stockbrügger RW. NonHelicobacter pylori bacterial flora during acid-suppressive therapy: differential findings in gastric juice and gastric mucosa. Aliment Pharmacol Ther 2001;15(3):379-88.

40. Mowat C, Williams C, Gillen D, Hossack M, Gilmour D, Carswell A, et al. Omeprazole, Helicobacter pylori status and alterations in intragastric milieu facilitating bacterial N-nitrosation. Gastroenterology 2000;119:339-47.

41. Oksanen A, Sipponen P, Karttunen R, Miettinen A, Veijola L, Sarna S, et al. Atrophic gastritis and Helicobacter pylori infection in outpatients referred for gastroscopy. Gut 2000;46:460-3.

42. Ley C, Mohar A, Guarner J, Herrera-Goepfert R, Figueroa LS, Parsonnet J. Screening Markers for Chronic Atrophic Gastritis in Chiapas, Mexico. Cancer Epidemiol Biomarkers \& Prev 2001;10:107-12.

43. Andrew W, Wyatt J, Dixon MF. Observer variation in the assessment of chronic gastritis according to the Sydney system. Histopathology 1994;25:317-22.

44. Genta RM. Recognizing atrophy: another step toward a classification of gastritis. Am J Surg Pathol 1996;20:S23-S30. 


\section{Chapter 8}

General discussion 


\section{General discussion}

Recent years have witnessed widespread use of acid-suppressive medication in the management of various acid-related gastrointestinal disorders. In the Netherlands, $1-2 \%$ of the general population uses maintenance therapy with proton pump inhibitors ${ }^{1}$. This is not surprising, considering that the PPIs have the best profile of efficacy and adverse events. As a result of the huge experience with these pharmacological agents, many issues centred around their potential side-effects have been presently answered. It is important to realise, however, that there is a limited understanding of the complex changes in intragastric environment during acid suppression. Such insights are needed, since they may be essential for patient safety and further drug development.

The gist of this thesis focused on the development of chronic atrophic gastritis and ECL cell hyperplasia during treatment with acidsuppressive medication. Particular attention was paid to the role of intragastric H.pylori and non-H.pylori bacteria in this context. Finally, the clinical utility of serological markers for the aforementioned conditions was investigated.

\section{Gastrin and enterochromaffin-like cell proliferation during acid suppression}

Hypergastrinaemia and the proliferation of gastric ECL cells are common in H.pylori-infected subjects treated long-term with acid suppression. So far, the alleged risk of developing gastric carcinoid tumors in this setting has not been substantiated ${ }^{2}$. However, the consequences of 'life-long' iatrogenic hypergastrinaemia on the ECL cells in humans are presently not known, favouring a prudent attitude in this respect. As such, the non-invasive screening for $E C L$ cell hyperplasia may be advisable in young GORD patients who, will not chose for antireflux-surgery, but instead will undergo long-term treatment with acid inhibitory medication ${ }^{3}$. Recently, Waldum et al. described elevated serum chromogranin A after short-term treatment with omeprazole, and proposed its use as a marker of ECL cell hyperactivity and/or hyperplasia ${ }^{4}$. In this thesis, we have expanded these observations by showing that long-term treatment with PPIs was particularly associated with elevated serum $\mathrm{CgA}$, compared to $\mathrm{H}_{2} \mathrm{RA}$ treatment and non-treated subjects (Chapter 3). Novel aspects emerged regarding the relationship between serum CgA levels and H.pylori-induced chronic gastritis during treatment with acid-suppressive medication (Chapter 4). H.pylori-positive subjects treated with PPIs 
displayed markedly elevated serum $\mathrm{CgA}$, reflecting more severe hyperplastic lesions of the ECL cells. Interestingly, the correlation between gastrin and $\mathrm{CgA}$ seemed to be fitted best by a quadratic function. In contrast to serum gastrin - which described a 'plateau phenomenon' - serum CgA levels gradually increased during long-term acid suppression and were paralleled by increasing prevalence of ECL cell hyperplasia. In view of these observations, we suggested that increased serum $\mathrm{CgA}$ during acid-suppressive therapy initially may reflect a hypersecretory state of the ECL cells, in response to sustained hypergastrinaemia, whilst during long-term acid suppression such increase is likely to be the result of ECL cell hyperplasia. From a clinical viewpoint, serum $\mathrm{CgA}$ was found to be a useful test in screening for ECL cell hyperplasia in this setting. Furthermore, we suggested a potential benefit for serum $\mathrm{CgA}$, compared to serum gastrin, as this test was equally sensitive but more specific than serum gastrin.

\section{Non-H.pylori bacteria during acid suppression}

The concept of 'intragastric bacteria' ranks, undoubtedly, among the most fascinating topics in the history of gastroenterology. In 1875, the old dictum that no bacteria could survive in the acidic milieu of the stomach faded when Bottcher \& Letulle demonstrated bacterial colonies in the mucosal margins of ulcers ${ }^{5}$. They suggested a causative bacterial agent in ulcer disease. In 1889, Jaworski was the first who described spiral microorganisms (Vibrio rugula) in the gastric contents from humans ${ }^{5}$. Bacteriological examinations then revealed a wide spectrum of intragastric microorganisms, such as Streptococci, Staphylococci, and bacilli, albeit of unknown significance for gastric pathology. It was about one century latter (1984), when Warren \& Marshal demonstrated that an infective agent, Campylobacter pyloridis (later named Helicobacter pylori) was responsible for gastric and duodenal (ulcer) disease ${ }^{6}$. This was the beginning of a tremendously rapid growing area, and H.pylori has polarised this scientific scene for more than two decades. By contrast, the earlier identified, other 'non-H.pylori bacterial species' acted an obscure role only. In 1975, Correa et al. proposed a model for the histopathogenesis of gastric cancer of the intestinal type ${ }^{7}$. This hypothesis was further substantiated by Ruddell et $a{ }^{\beta, 9}$, who showed that chronic hypochlorhydria (e.g., due to atrophic gastritis with/without pernicious anaemia or post-gastrectomy) promotes the overgrowth of intragastric nitrate-reducing bacteria, which in turn may lead to an increased production of carcinogenic NOCs. These could initiate a series of mutations resulting in intestinal metaplasia, dysplasia, and finally gastric carcinoma. It has been argued, however, that given the technical difficulties in measuring NOCs, as well as the lagtime 
between the aforementioned events and development of gastric carcinoma it must be difficult to confirm or refute such theory ${ }^{10}$.

After the introduction of potent inhibitors of gastric acid secretion, much scientific interest has been directed to the intragastric growth of non-H.pylori bacteria ${ }^{11}$; thus far the clinical relevance of this phenomenon remains controversial. In line with previous studies by our group (in subjects with low-acid states of different origin) ${ }^{12,13}$, in this thesis we have shown that non-H.pylori bacteria not only contaminate the gastric juice but also colonise the gastric mucosa of the majority of patients treated long-term with acid suppression (Chapter 5). Culture of gastric juice identified mainly bacteria of oropharyngeal origin, although faecal-type flora was also isolated in some cases. Comparison between gastric luminal and mucosal growth of non-H.pylori bacteria revealed that the latter could provide important information concerning the changes in intragastric environment under these conditions. Thus, treatment with PPIs resulted in significantly higher $\mathrm{pH}$ levels and higher prevalence of non-H.pylori bacteria in gastric juice than the treatment with $\mathrm{H}_{2}$ RAs. Surprisingly, in spite of these differences in gastric juice bacterial overgrowth, the PPI-treated subjects and the $\mathrm{H}_{2} \mathrm{RA}$-treated subjects did not differ with regard to non-H.pylori bacterial growth in the gastric mucosa ( $\pm 60 \%$ in both groups). A plausible interpretation would be that the gastric luminal bacterial growth is a pH-dependent phenomenon, whilst the gastric mucosa during acid suppression seems to behave as a constant 'bacterial reservoir'.

Remarkably, in most cases non-H.pylori bacteria were located superficially, in the gastric mucus layer, but occasionally they co-located with H.pylori, on deeper mucosal positions (i.e., gastric crypts) (Chapter 5). With these observations in mind, we next addressed the relationship between gastric mucosal H.pylori, non-H.pylori bacteria and chronic gastritis during acid-suppressive therapy.

In a larger context, it is worthwhile to mention that, as of today, increasing evidence supports a role of commensal bacteria in several models of compromised gut (such as in patients with inflammatory bowel disease or celiac disease $)^{14}$. In view of this, to argue that intragastric non-H.pylori bacteria (secondary to acid suppression) is an 'innocent bystander' only is a dogmatic viewpoint: it should be pointed out that such bacteria represent, de facto, the predominant intragastric flora during acid suppression, which shares the habitat with the recognised gastric pathogen (H.pylori), and could yield complex, largely unidentified pathogenicity factors.

In this thesis we presented 'back-to-back' arguments that the gastric double infection with H.pylori and non-H.pylori bacteria during acid suppression may play a role in the aggravation of chronic gastritis and accelerated development of atrophy. H.pylori-positive subjects treated 
long-term with acid suppression were characterised by three features: non-H.pylori bacterial growth in the gastric mucosa, increased risk for atrophic body gastritis and increased serum pro-inflammatory cytokine levels, particularly IL-1 $\beta$ and IL-8. This was in stark contrast to the H.pylori-negative subjects on long-term PPI treatment, who had a very low rate of atrophy. The simultaneous gastric infection with H.pylori and non-H.pylori bacteria was associated with the highest serum levels of pro-inflammatory cytokines and the highest risk for atrophic gastritis. The type of interaction between H.pylori and non-H.pylori bacteria appeared to be synergistic. Additionally, we found that H.pylori cagApositivity increased the risk of atrophy, particularly of the antral mucosa. Taken together, these results suggest that on a background of compromised gastric mucosal barrier (caused by the H.pylori infection), the co-infection with non-H.pylori bacterial strains may upregulate the pro-inflammatory cytokine response, thereby leading to aggravation of the chronic gastritis and a more rapid development of atrophy (Chapter 6). However, further investigation is needed to elucidate the cellular and molecular mechanisms by which a double gastric infection may contribute to the pathogenesis of chronic atrophic gastritis.

The strength of these data resides in the large study material (including a sizeable control group). Furthermore, in an attempt to reflect an everyday clinical situation, patients were recruited consecutively via an open-access endoscopy unit. Every effort was made to estimate the role of the time factor in the development of chronic atrophic gastritis. However, data were gathered in a crosssectional design. Hence, the question as to whether non-H.pylori bacterial flora is a causal risk factor for the development of atrophic gastritis or merely a marker for a risk condition cannot be finally answered and remains open for future research.

In this sense, it would be important to further identify these bacteria through culture and/or molecular methods, to unravel their potential pathogenicity factors (e.g., adhesion properties, production of cytotoxic and pro-inflammatory agents), as well as their potential role in the modulation of immune response. It is worth commenting that we found a weak association between presence of non-H.pylori bacteria alone, serum pro-inflammatory cytokines, and the risk for atrophy (Chapter 6), with numerically higher cytokine levels in these subjects (especially IL8) and a trend towards increased risk for body atrophy compared to subjects without any type of bacteria. Importantly, recent evidence from animal studies indicates that concurrent infections may alter the Th1polarised cytokine response associated to the H.pylori infection ${ }^{15}$. The behaviour of Th1/Th2 balance during the gastric infection with H.pylori and other non-H.pylori bacteria was not addressed in these studies. It will be, therefore, the challenge of future research to define the 
peripheral and gastric mucosal $T$ cell phenotype in relation to total intragastric bacteria. Furthermore, longitudinal studies are needed to elucidate the time-course of gastric mucosal changes due to a double bacterial infection.

Atrophic body gastritis and intestinal metaplasia are considered preneoplastic gastric lesions ${ }^{16,17}$, and therefore efficient screening for such lesions is an important public health issue. We have investigated whether the measurement of serum pro-inflammatory cytokines in this context offers additional information on the histomorphologic status of the body mucosa, compared to the measurement of serum gastrin and serum pepsinogens (Chapter 7). In an attempt to optimise the prediction of body atrophy, we have defined the atrophic body gastritis $(A B G)$ index, that is the ratio between the simultaneously measured IL8 level and pepsinogen $A: C$. The $A B G$ index performed significantly better than serum gastrin alone and serum pepsinogen $A: C$ alone; at a cut-off value of $1.8 \mathrm{pg} / \mathrm{ml}$ the total proportion of well-predicted cases was $91 \%$. It is conceivable that besides indicating 'established' glandular loss in the body mucosa, this test may reflect ongoing chronic active inflammation, which in long-term may progress to gastric cancer.

The results presented in this thesis add to a growing body of evidence, indicating that chronic atrophic gastritis is a multifactorial condition. They also provide compelling arguments that, apart from the genetic set-up and H.pylori-related factors, the environmental factors, like chronic use of acid-suppressive medication, may play an important role in this development. Figure $\mathbf{8 . 1}$ summarizes the available data concerning the pathophysiology of chronic atrophic gastritis: chronic hypochlorhydria and subsequent overgrowth of non-H.pylori bacteria may enhance and perpetuate the gastric mucosal damage initiated by the H.pylori infection through: (i) increased $\mathrm{N}$-nitrosation ${ }^{18}$, (ii) bacterial production of acetaldehyde ${ }^{19}$, and (iii) upregulation of the proinflammatory cytokines ${ }^{20}$.

\section{What are the clinical implications of these studies?}

Given the potential harmful effect of the double gastric infection with H.pylori and non-H.pylori bacteria - namely worsening of body gastritis and an accelerated development of body atrophy with hyperplasia of the ECL cells - one should consider a strategy of testing for H.pylori followed by eradication therapy when positive, before starting long-term gastric acid inhibition. 


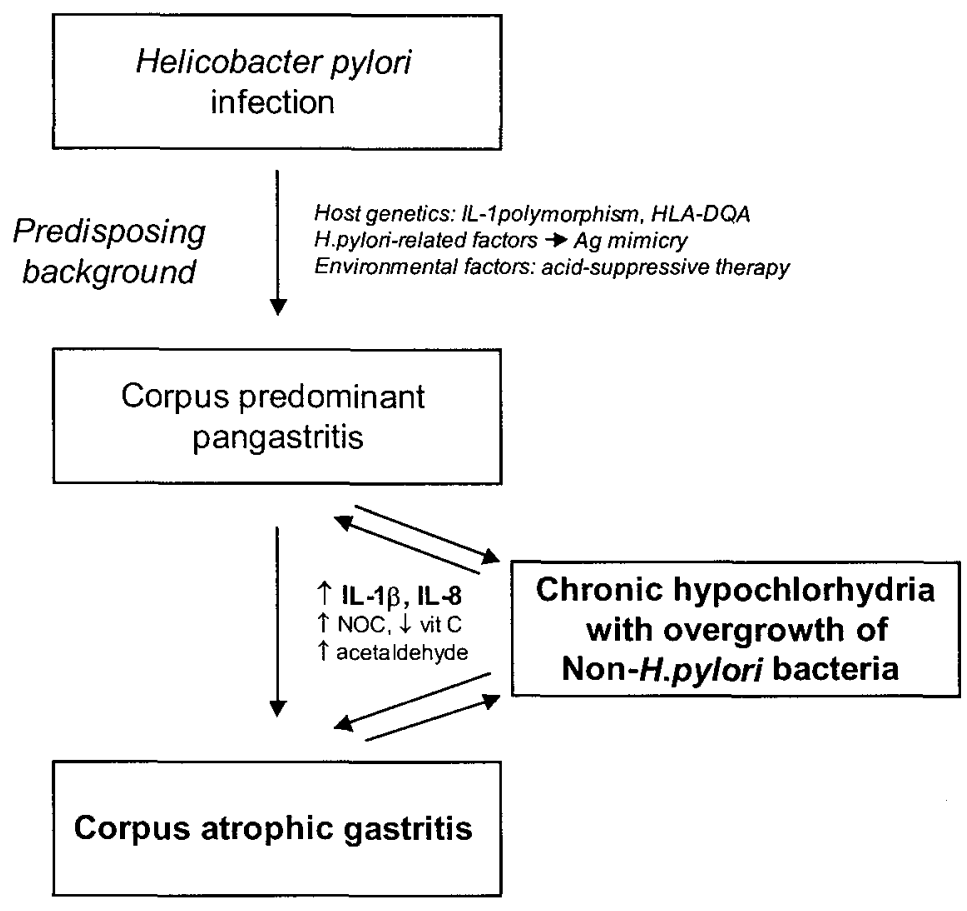

Figure 8.1 Schematic diagram illustrating possible key events in the development of corpus atrophic gastritis.

The most important argument in favour of such strategy is the potential reduction in chronic body gastritis and development of atrophy ${ }^{21,22}$, which is a precursor lesion for non-cardia gastric cancer. The arguments against this strategy include the cost, the potential adverse events associated to antibiotic therapy, and potential negative consequences of eradication, such as increasing incidence of GORD ${ }^{23}$. Pending available evidence, the recent European Consensus regarding H.pylori management guidelines (Maastricht, 2000) ${ }^{24}$ stated that: 'H.pylori should be eradicated in patients requiring long-term profound acid suppression'. The present studies will probably increase the level of scientific evidence in favour of this clinical policy. 


\section{References}

1. Hurekamp GJB, Grundmeyer HGLM, Bindels PJE, Tytgat GNJ, van der Hulst RWM. A population-based inventarisation of long-term acid suppressant use in 24 general practices in the Netherlands. Digestion 1998;59(Suppl.3):101.

2. Yeomans ND, Dent J. Personal review: alarmism or legitimate concerns about long-term suppression of gastric acid secretion? Aliment Pharmacol Ther 2000;14:267-71.

3. Waldum HL, Brenna E. Personal review: is profound acid inhibition safe? Aliment Pharmacol Ther 2000;14:15-22.

4. Waldum HL, Arnestad JS, Brenna E, et al. Marked increase in gastric acid secretory capacity after omeprazole treatment. Gut 1996;39:649-53.

5. Modlin IM, Farhadi J, Kidd M. From the pump to the helix. In: Hunt RH, Tytgat GNJ, editors, Helicobacter pylori. Basic Mechanisms to Clinical Cure. Dordrecht: Kluwer Academic Publishers 2000;347-72.

6. Marshall BJ, Warren JR. Unidentified curved bacilli in the stomach of patients with gastric and peptic ulceration. Lancet 1984;i:1311-15.

7. Correa P, Haenszel W, Cuello $C$, Tannenbaum S, Archer M. A model for gastric cancer epidemiology. Lancet 1975;2:58-60.

8. Ruddell WSJ, Bone ES, Hill MJ, Blendis LM, Walters CL. Gastric juice nitrite. A risk factor for cancer in the hychlorhydric stomach? Lancet 1976;ii:1037-1039.

9. Ruddell WSJ, Bone ES, Hill MJ, Walters CL. Pathogenesis of gastric cancer in pernicious anaemia. Lancet 1978;ii:521-523.

10. Houben GMP, Stockbrügger RW. Bacteria in the aetio-pathogenesis of gastric cancer: a review. Scand J Gastroenterol 1995;30(S 212):13-8.

11. Stockbrügger RW, Cotton-PB, Eugenides N, Bartholomew BA, Hill MJ, Walters CL. Intragastric nitrites, nitrosamines, and bacterial overgrowth during cimetidine treatment. Gut 1982;23(12):1048-54.

12. Jonkers D, Gisbertz I, de Bruine A, Bot F, Arends JW, Stobberingh $E$, et al. Helicobacter pylori and non-Helicobacter pylori bacterial flora in gastric mucosal and tumour specimens of patients with primary gastric lymphoma. Eur J Clin Invest 1997;27:885-92.

13. Jonkers D, Houben $P$, Hameeteman W, Stobberingh $E$, de Bruine A, Arends JW, et al. Differential features of gastric cancer patients, either Helicobacter pylori positive or Helicobacter pylori negative. Ital J Gastroenterol Hepatol 1999;31(9):836-41.

14. Sartor RB. The role of luminal bacteria in colitis: more than an antigenic drive. Eur $\mathrm{J}$ Clin Invest 1998;28(12):1027-9.

15. Fox JG, Beck P, Dangler CA, Whary MT, Wang TC, Shi HN, et al. Concurrent enteric helminth infection modulates inflammation and gastric immune responses and reduces helicobacter-induced gastric atrophy. Nature-Medicine 2000;6(5):536542.

16. Sipponen P, Kekki M, Haapakoski J, Ihamäki T, Siurala M. Gastric cancer risk in chronic atrophic gastritis: statistical calculations od cross-sectional data. Int J Cancer 1985;35:173-7.

17. Tatsuta $M$, lishi $H$, Kakaizumi $A$, et al. Fundal atrophic gastritis as a risk factor for gastric cancer. Int J Cancer 1993;53:70-4.

18. Mowat C, Williams C, Gillen D, Hossack M, Gilmour D, Carswell A, et al. Omeprazole, Helicobacter pylori status, and alterations in the intragastric milieu facilitating bacterial N-nitrosation. Gastroenterology 1999;116:339-47. 
19. Väkeväinen $S$, Tillonen $J$, Salaspuro $M$, Jousinies-Somer $H$, Nuutinen $H$, Färkkilä M. Hypochlorhydria induced by a proton pump inhibitor leads to intragastric microbial production of acetaldehyde from ethanol. Aliment Pharmacol Ther 2000;14:1511-8.

20. Sanduleanu S, Jonkers $D$, de Bruïne A, Hameeteman W, Stockbrügger RW. Double infection of the stomach with Helicobacter pylori and non-Helicobacter pylori bacteria: increase of pro-inflammatory cytokines and development of atrophic gastritis. Aliment Pharmacol Ther 2001;in press.

21. Schenk BE, Kuipers EJ, Nelis GF, Bloemena E, Thijs JC, Snel P, et al. Effect of Helicobacter pylori eradication on chronic gastritis during omeprazole therapy. Gut 2000;46:615-21.

22. Moayyedi P, Wason C, Peacock R, Walan A, Bardhan K, Axon ATR, et al. Changing patterns of H.pylori gastritis in long-standing acid suppression. Helicobacter 2001;5(4):206-14.

23. O'Connor HJ. Helicobacter pylori and gastro-esophageal reflux disease - clinical implications and management. Aliment Pharmacol Ther 1999(13);2:117-27.

24. Malfertheiner $P$ et al. Current Concepts in the Management of Helicobacter pylori Infection - The Maastricht Consensus Report 2000. Gut 2001 (in preparation). 


\section{Chapter 9}

Summary and concluding remarks 


\section{Summary}

This thesis enlightens some aspects concerning the development of chronic atrophic gastritis and ECL cell hyperplasia during acidsuppressive therapy. Special attention was dedicated to the role of intragastric H.pylori and non-H.pylori bacteria in this context. Finally, the clinical utility of serological markers for these conditions was addressed.

In Chapter 1, an overview is presented of current knowledge about the changes in gastric mucosa and luminal environment during treatment with acid-suppressive medication. In summary, worldwide experience with these pharmacological agents presently reassures their general safety. However, the mechanistic aspects underlying their gastrointestinal effects are still far from complete understanding. Such information is needed, as this may have impact on patient care and further drug development.

Chapter 2 presents the aims and outline of the thesis.

In Chapter 3 the relationship between serum gastrin and serum $\mathrm{CgA}$ levels during medium- and long-term acid-suppressive therapy was investigated. We reported significantly higher serum gastrin and serum $\mathrm{CgA}$ levels after long-term PPI therapy compared to $\mathrm{H}_{2} \mathrm{RA}$ therapy and non-treated controls. Elevated serum CgA correlated to positive H.pylori serology and the length of acid inhibitory treatment. We next sought to determine the relationship between serum $\mathrm{CgA}$ levels and fundic $\mathrm{ECL}$ cell hyperplasia during acid suppression (Chapter 4). H.pylori-positive subjects treated long-term with PPls had markedly elevated serum $\mathrm{CgA}$, which correlated to the severity of ECL cell hyperplasia. The clinical utility of serum $\mathrm{CgA}$ in this regard was compared to that of serum gastrin. As such, we found that during long-term acid suppression, serum CgA was equally sensitive but more specific than serum gastrin for the detection of ECL cell hyperplasia. In view of the potential negative consequences of iatrogenic hypergastrinaemia on gastric mucosa, it might be prudent to monitor serum $\mathrm{CgA}$ levels during longterm acid suppression. This holds especially true in young GORD patients, not referred for antireflux-surgery.

Chapter 5 describes the gastric luminal and mucosal growth of nonH.pylori bacteria during acid suppression. In gastric juice, prevalence rate for non-H.pylori bacteria was higher in the PPI group than controls and $\mathrm{H}_{2} \mathrm{RA}$ group; no difference was found between the $\mathrm{H}_{2} \mathrm{RA}$ group and controls. In gastric mucosa, prevalence rates for non-H.pylori bacteria were higher in patients on acid suppresion - either with PPIs or $\mathrm{H}_{2} \mathrm{RAs}$ than in the controls; no difference was found between the PPI group and $\mathrm{H}_{2} \mathrm{RA}$ group. Both luminal and mucosal growth of non-H.pylori 
bacteria were significantly greater in H.pylori-positive than -negative patients on PPIs. Luminal growth of non-H.pylori flora increased with the intragastric $\mathrm{pH}$ level, while mucosal bacterial growth increased with the duration of acid inhibition.

In Chapter 6 the relationship between intragastric bacteria and chronic atrophic gastritis during acid-suppressive therapy has been studied. The hypothesis tested was that the gastric double infection with H.pylori and non-H.pylori bacteria may bring about an enhanced proinflammatory cytokine response, thereby contributing to the accelerated development of atrophic gastritis under these conditions. We reported that the simultaneous presence of H.pylori and non-H.pylori bacteria was associated with elevated serum pro-inflammatory cytokines, particularly IL-1 $\beta$ and IL-8, and a markedly increased risk for atrophic gastritis. The type of interaction between H.pylori and non-H.pylori bacteria was synergistic. In view of these findings, we suggested that non-H.pylori bacteria may be a co-factor in the development of atrophic gastritis during acid-suppressive therapy. Further studies are needed, however, to elucidate whether this association reflects a causative role.

Chapter 7 addressed the clinical utility of measuring serum proinflammatory cytokines - IL-1 $\beta, \mathrm{IL}-6$, and IL-8 - together with serum gastrin and serum pepsinogens in screening for atrophic body gastritis. In an attempt to optimise the detection of this condition we have defined the atrophic body gastritis ( $A B G)$ index, as the ratio between the simultaneously measured IL-8 level and pepsinogen A:C. The $A B G$ index performed significantly better than serum gastrin alone and serum pepsinogen $\mathrm{A}: \mathrm{C}$ alone. Additionally, such test seems to reflect ongoing chronic active inflammation, which in long-term may evolve to gastric cancer. We therefore recommend its use in screening for atrophic body gastritis in large-scale population studies.

Finally, Chapter 8 synthesises the results of these studies, and indicates their possible implications for clinical practice and future research into this area. 


\section{What do these studies add to current knowledge?}

- Long-term acid suppression in the presence of H.pylori infection is associated with:

- non-H.pylori bacterial growth in the gastric mucosa

- increased serum pro-inflammatory cytokine levels

- high rate of atrophic body gastritis and ECL cell hyperplasia.

- The gastric double infection with H.pylori and non-H.pylori bacteria increases the risk of atrophic body gastritis, possibly through eliciting an enhanced pro-inflammatory cytokine response. In view of this, H.pylori eradication should be recommended before the start of long-term acid suppression in order to prevent the potential cumulative damage to the mucosa due to a double bacterial infection.

- The $A B G$ index is a reliable screening test for atrophic body gastritis. Additionally, serum $\mathrm{CgA}$ is a useful screening test for $E C L$ cell hyperplasia, being more specific than serum gastrin in this regard.

In conclusion, the research described in this thesis may be relevant to our evolving understanding of chronic atrophic gastritis as a multifactorial process. The host genetic factors set up the baseline immune response to the H.pylori infection. Additionally, the environmental factors might play a major role in the modulation of this response, and the final determination of disease outcome.

It is probably too early to draw firm conclusions about the interrelation between H.pylori and non-H.pylori bacteria in the pathogenesis of chronic atrophic gastritis and gastric cancer. As a first step in this sense, efforts should be directed to identify the total intragastric bacteria in the context of acid suppression, their pathogenicity factors, as well as their potential role in gastric immune response.

Finally, we have gathered now substantial evidence to advocate for the eradication of H.pylori in patients considered for long-term acidsuppressive therapy. 


\section{Chapter 10}

Samenvatting \& conclusies 
Samenvatting en conclusies

154 


\section{Samenvatting}

In dit proefschrift worden verscheidene aspecten betreffende de ontwikkeling van chronische atrofische gastritis en hyperplasie van de ECL cellen tijdens de behandeling met maagzuurremmende medicatie beschreven. Bij deze ontwikkeling wordt er speciale aandacht besteed aan de rol van H.pylori en non-H.pylori maagbacteriën. Tevens is de klinische bruikbaarheid van serologische markers voor chronische atrofische gastritis en voor hyperplasie van de ECL cellen bepaald.

Het bestudeerde cohort bestond uit 230 opeenvolgende dyspeptische patiënten die een gastroscopie ondergingen in het AZM. Hierbij werden drie groepen onderscheiden: patiënten met gastro-oesofageale reflux ziektes die werden behandeld met proton pomp inhibitoren ( $P P I, n=117$ ) of met histamine ${ }_{2}$-receptor antagonisten $\left(H_{2} R A, n=37\right)$ en niet behandelde controle patiënten, met normale endoscopische bevindingen $(n=76)$.

In Hoofdstuk 1 wordt een overzicht gegeven van de actuele kennis ten aanzien van de veranderingen in het maagmilieu tijdens de behandeling met maagzuurremmers, in het bijzonder de hypergastrinaemie, de proliferatie van ECL cellen en intragastrische bacteriële overgroei. De pathofysiologie van bovengenoemde veranderingen is vooralsnog echter weinig bekend. Kennis omtrent deze aspecten is essentieel voor de klinische behandelingstrategieën en toekomstige ontwikkelingen van de maagzuurremmende medicatie.

In Hoofdstuk 2 wordt de achtergrond van dit proefschrift en de daaruit voortvloeiende vragen besproken.

In Hoofdstuk 3 wordt de relatie bestudeerd tussen serum gastrine en serum chromogranine $A(\mathrm{CgA})$, een marker voor neuroendocrine proliferatie, tijdens middellange en langdurige maagzuurremming, om na te gaan of deze behandelingen in staat zijn ECL hyperactiviteit of ECL cell hyperplasie te induceren.

Serum gastrine en serum $\mathrm{CgA}$ waarden waren significant hoger bij patiënten die behandeld werden met een PPI ten opzichte van $\mathrm{H}_{2} \mathrm{RA}$ behandelde en de niet-behandelde controles. Er werden positieve correlaties gevonden tussen serum $\mathrm{CgA}$ waarden en een positieve serologie voor H.pylori en tussen serum $\mathrm{CgA}$ en de duur van de behandeling met een PPI. 
In Hoofdstuk 4 wordt de relatie onderzocht tussen serum gastrine, serum CgA waarden en hyperplasie van de ECL cellen in de mucosa van de maagcorpus/fundus tijdens maagzuurremmende therapie. Hierbij werd aangetoond dat $H$.pylori-positieve patiënten met langdurige PPI behandeling worden gekenmerkt door een toename in serum CgA waarden. Deze verhoogde waarden zijn gecorreleerd met de aanwezigheid en de histologische graad van de hyperplasie van de ECL cellen. Daarnaast is de klinische bruikbaarheid van serum $\mathrm{CgA}$ als marker voor de ECL cel hyperplasie vergeleken met serum gastrine: serum CgA was even sensitief $(91.3 \%)$, maar had een hogere specificiteit dan serum gastrine $(73 \%$ vs $43 \%, P<0.0001)$ voor de detectie van hyperplasie van de ECL cellen bij patiënten die langdurig behandeld zijn met maagzuurremmers.

Vanwege het potentiele negatieve effect van de iatrogene hypergastrinaemie (b.v. inductie van neoplasie in de maag en elders), is het wenselijk om de $\mathrm{CgA}$ waarden bij deze patiënten te monitoren. Dit geldt vooral voor jonge patiënten met gastro-esofageale reflux ziektes die langdurig behandeld moeten worden met maagzuurremmers.

De intragastrische bacteriële flora tijdens zuurremmende therapie wordt beschreven in Hoofdstuk 5. Hiervoor is de overgroei van non-H.pylori bacteriën in het maagsap en in de mucosa van de maag bestudeerd. $\mathrm{Er}$ werd aangetoond dat de PPI groep een significant hogere prevalentie heeft van non-H.pylori bacteriën in het maagsap ten opzichte van de $\mathrm{H}_{2} \mathrm{RA}$ groep en de controles ( $58.7 \%$ vs $22.6 \%$ en vs $30.6 \%$ ). Daarnaast werd aangetoond dat zowel de PPI groep als ook de $\mathrm{H}_{2} \mathrm{RA}$ groep een significant hogere prevalentie heeft van de non-H.pylori bacteriën in de mucosa dan de controles ( $61.1 \%$ en $59 \%$ vs $29 \%$ ). Zoals werd verwacht was de overgroei van de non-H.pylori bacteriën in het maagsap positief gecorreleerd met de intragastrische $\mathrm{pH}$-waarde. Het was echter opmerkelijk dat de overgroei van de non-H.pylori flora in de mucosa steeg met de duur van de behandeling en dat non-H.pylori bacteriën significant vaker werden aangetoond bij de H.pylori-positieve patiënten dan bij de H.pylori-negatieve patiënten. Het kan verondersteld worden dat de maagmucosa een 'reservoir' vormt voor non-H.pylori bacteriën tijdens krachtige en langdurige maagzurremming.

In Hoofdstuk 6 wordt de nadruk gelegd op de relatie tussen de intragastrische bacteriële flora en de ontwikkeling van chronische (atrofische) gastritis tijdens maagzuurremmende therapie. Het is bekend dat bij H.pylori positieve patiënten langdurige behandeling met maagzuurremmende medicatie geassocieerd is met een toename van corpus gastritis en een versnelde ontwikkeling van chronische 
atrofische gastritis. Het pathofysiologisch mechanisme dat hieraan ten grondslag ligt is tot op heden onbekend.

De hypothese van de in dit proefschrift gepresenteerde studie was dat een dubbele infectie van de maag met H.pylori én non-H.pylori bacteriën tijdens zuurremmende therapie zou kunnen leiden tot een verhoogde inflammatoire respons, welke aanleiding kan geven tot een versnelde ontwikkeling van atrofische gastritis. Omdat atrofie in de corpus mucosa een precursor laesie is van maagkanker, werd specifiek gekeken naar het vóórkomen hiervan.

Met behulp van een logistische regressie analyse bleek dat H.pylori (OR 11.7), non-H.pylori bacteriën (OR 6.4) maar met name de gelijktijdige aanwezigheid van beide typen bacteriën (OR 20.4) geassocieerd was met een verhoogd risico voor atrofie in de corpus mucosa. Daarnaast was de gelijktijdige aanwezigheid van $H$.pylori en non-H.pylori bacteriën geassocieerd met een sterke toename van de serum pro-inflammatoire cytokines, IL-1 $\beta$, IL-6 en IL-8. De interactie tussen H.pylori en non-H.pylori bacteriën bij deze ontwikkeling was synergistisch. Gebaseerd op deze bevindingen stellen we voor dat de non-H.pylori bacteriële flora een co-factor is bij de ontwikkeling van atrofische gastritis tijdens maagzuurremming. Longitudinale studies zijn nodig om na te gaan of dit verband causaal is.

Deze studie heeft directe consequenties voor de klinische behandeling van patiënten die in aanmerking komen voor langdurige maagzuuremmende medicatie. Bij deze patiënten is screening op de aanwezigheid van H.pylori en de eradicatie hiervan aan te bevelen vóór de start van een langdurige behandeling met maagzuurremmers. Hiermee kan het potentiele schadelijke effect van een dubbele infectie van de maag voorkómen worden.

In Hoofdstuk 7 wordt de klinische bruikbaarheid onderzocht van de bepaling van het profiel van de pro-inflammatoire cytokines, IL-1 $1 \beta$, IL-6 en IL-8, samen met serum gastrine en serum pepsinogeen $A$ en $C$ voor de screening van atrofische corpus gastritis. Hoge serum gastrine waarden en een lage pepsinogeen $A: C$ ratio zijn bekende voorspellers van atrofie in de corpus mucosa. De mogelijke diagnostische waarde hierbij van pro-inflammatoire cytokines is niet bekend. Daarom hebben wij de zogenoemde ' $A B G$ (atrophic body gastritis) index' voorgesteld en gedefinieerd als de ratio tussen serum IL-8 waarde en serum pepsinogen A:C. Deze $A B G$ index blijkt een significant betere voorspeller voor atrofische corpus gastritis te zijn dan serum gastrine en serum pepsinogeen $\mathrm{A}: \mathrm{C}(\mathrm{P}<0.05)$. Bovendien weerspiegelt deze test de 'continue chronische ontsteking' van de corpus mucosa, welke aanleiding kan geven tot de ontwikkeling van atrofische gastritis en maagkanker. De $A B G$ index zou gebruikt kunnen worden bij screening 
van 'hoge-risico' populaties als voorspeller voor atrofische gastritis in het corpus.

Hoofdstuk 8 bevat de slotdiscussie en conclusies omtrent de veranderingen in het maagmilieu tijdens middellange en langdurige behandeling met maagzuurremmers, waarbij de gegevens van de klinische studies, gepresenteerd in de voorgaande hoofdstukken, worden geïntegreerd. De klinische implicaties van deze bevindingen worden benadrukt.

\section{Wat voegen de studies toe aan de huidige kennis?}

- H.pylori-positieve patiënten die langdurig maagzuurremmers hebben gebruikt worden gekenmerkt door:

- een non-H.pylori bacteriële groei in de maagmucosa,

- een toename van de pro-inflammatoire cytokines in het serum, en

- een versnelde ontwikkeling van atrofische gastritis in het corpus.

- De dubbele infectie van de maag met H.pylori en non-H.pylori bacteriën tijdens zuurremmende therapie is geassocieerd met een verhoogd risico voor atrofie, mogelijk als gevolg van een verhoogde inflammatoire respons.

Daarom is een H.pylori 'test and treat' strategie geïndiceerd alvorens te starten met langdurige maagzuurremmende therapie, om zo het potentiele schadelijke effect van een dubbele infectie van de maag te voorkómen.

- De $A B G$ index is een betrouwbare screeningstest voor atrofische gastritis in het corpus van de maag.

- Serum CgA is een betrouwbare screeningstest voor de ECL cel hyperplasie tijdens zuurremming en specifieker dan serum gastrine.

De in dit proefschrift beschreven resultaten kunnen het inzicht in de pathogenese van chronische atrofische gastritis als precancereuze laesie van de maag en veiligheidsaspecten van de behandeling met maagzuurremmers vergroten. Genetische factoren spelen een belangrijke rol bij de ontwikkeling van chronische atrofische gastritis in de aanwezigheid van H.pylori, maar zoals nu blijkt kunnen milieu factoren, als een langdurige behandeling met maagzuurremmers, deze ontwikkeling moduleren en de klinische uitkomst bepalen.

Het is waarschijnlijk te vroeg om definitieve conclusies te trekken betreffende de relatie tussen H.pylori en non-H.pylori bacteriën bij de ontwikkeling van atrofische gastritis en maagkanker. Een eerste stap 
hiertoe zou het identificeren moeten zijn van de totale intragastrische flora en vervolgens het bestuderen van de pathogenetische mechanismen en de mogelijke rol van deze bacteriën bij de lokale en systemische immuunrespons.

De in dit proefschrift beschreven studies ondersteunen het praktische concept dat eradicatie van H.pylori, alvorens te starten met maagzuurremmende therapie, noodzakelijk is. 
Addendum

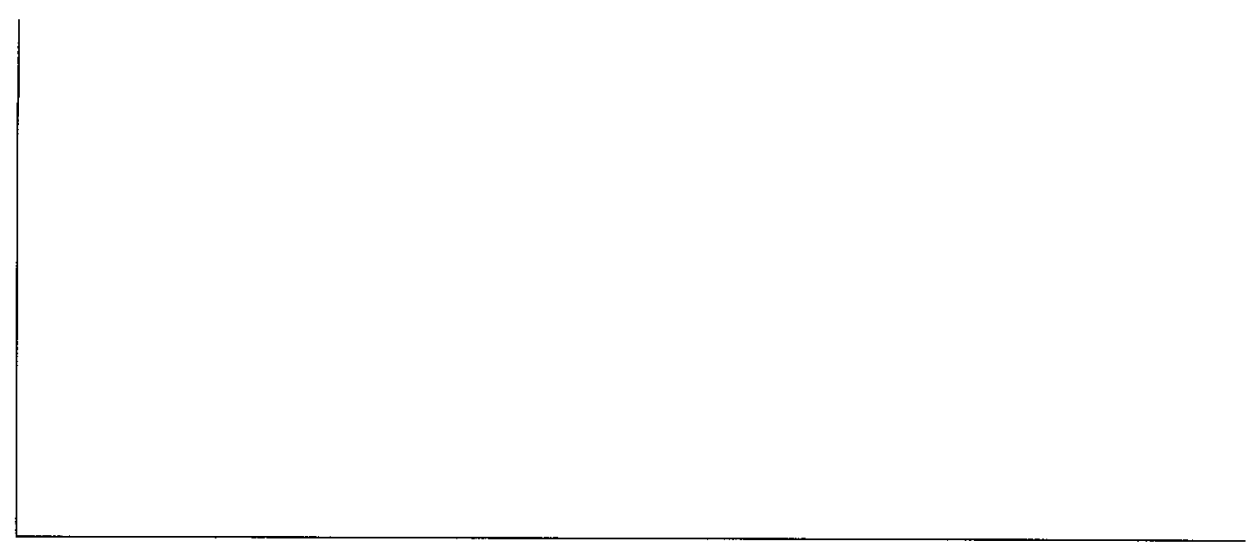


A

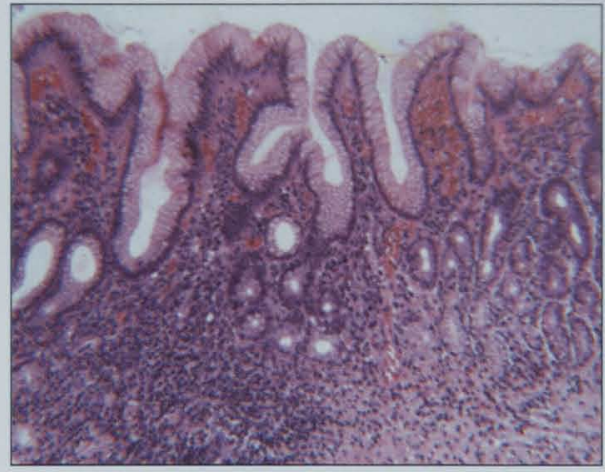

B

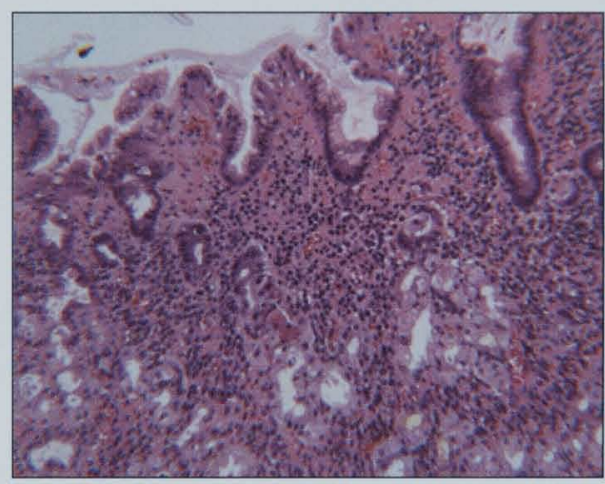

$\mathrm{C}$

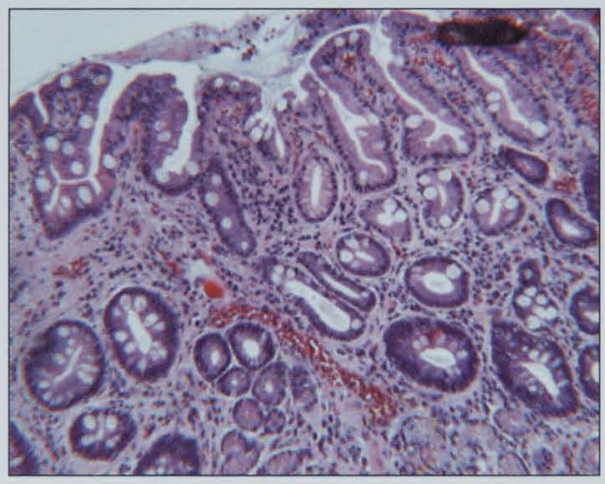

$\mathrm{D}$

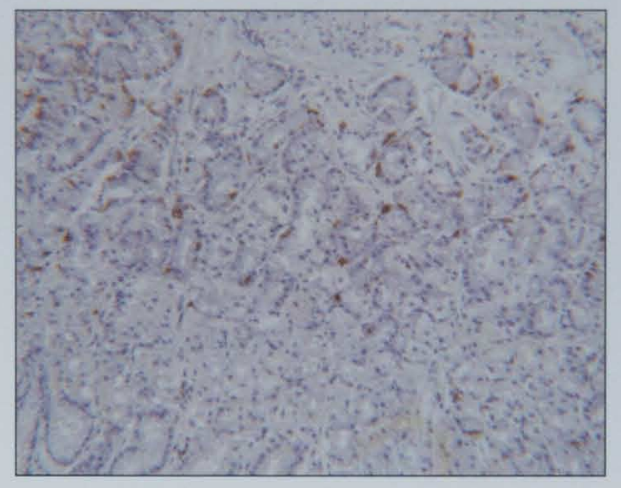

$\mathrm{E}$

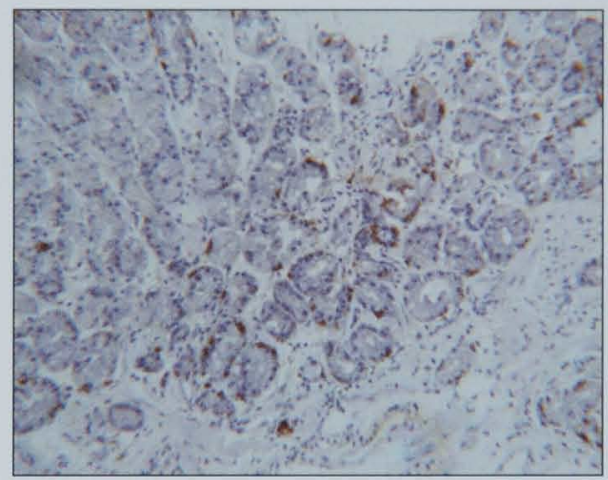

F

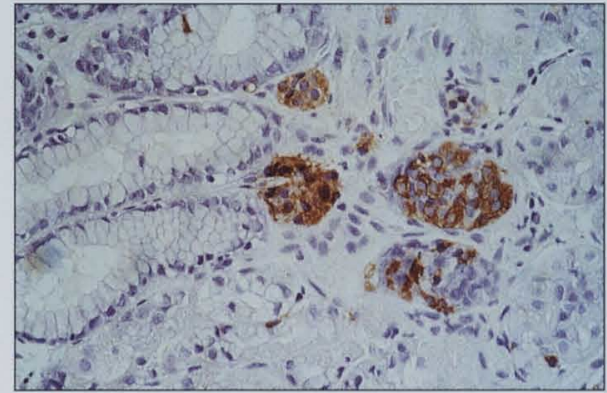

Different patterns of chronic gastritis. (A) diffuse non-atrophic gastritis of the corpus mucosa; (B) antral predominant atrophic gastritis; (C) corpus predominant atrophic gastritis with intestinal metaplasia (H\&E). Different patterns of ECL cell hyperplasia in the oxyntic mucosa of patients under long-term acid-suppressive therapy. (D) diffuse; (E) linear; $(F)$ micronodular growth pattern ( $\mathrm{CgA}$ immunostaining). Original magnification $\times 200$. 
Aknowledgement

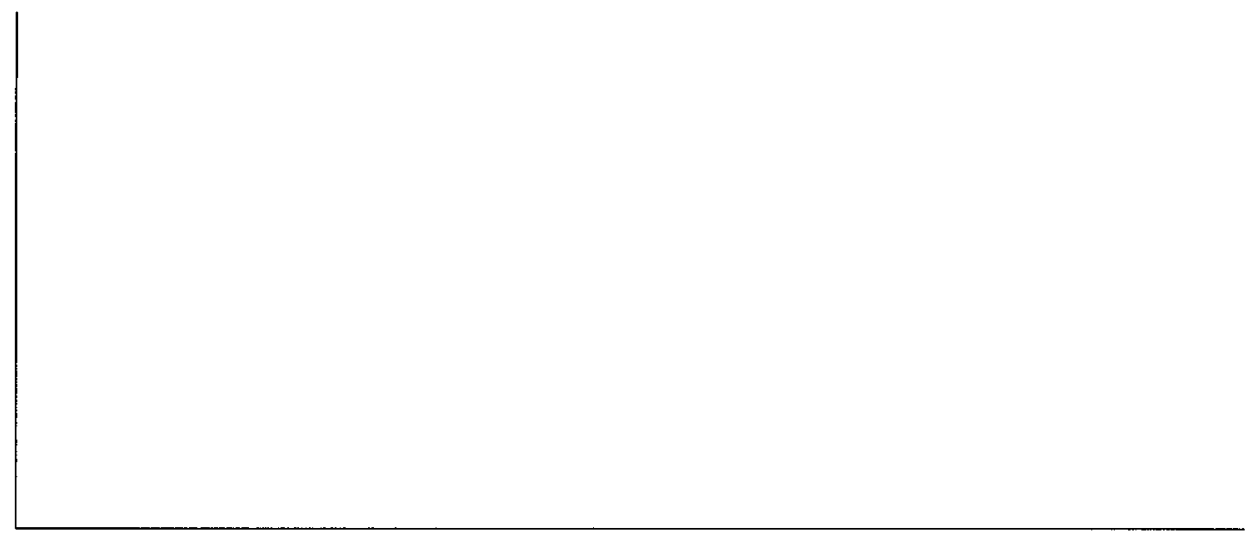




\section{Acknowledgement}

At the very beginning, it was a white sheet of paper and a puzzling equation with many variables:

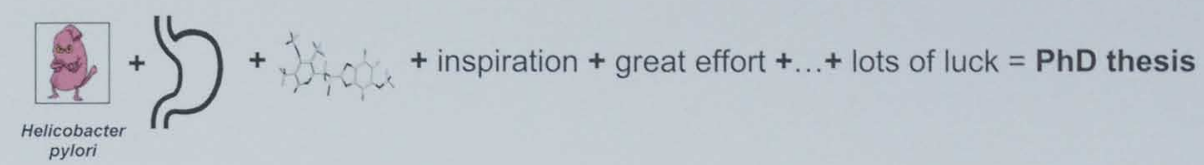

I was carefully looking to find the right words, when my Dutch colleagues just told me: 'je moet ergens beginnen' (you should start somewhere). So I did! I was always inspired by George Bernard Shaw's words: 'If you have an apple and I have an apple and if we exchange these apples then we will still each have one apple. But if you have an idea and I have an idea and if we exchange these ideas, then each of us will have two ideas...' An extrapolation of this wisdom to my experience in the last years would be: 'Een proefschrift is altijd teamwerk' ( $\mathrm{A} P \mathrm{Ph}$ thesis always means teamwork). Not only in the sense of resourceful thinking, but mainly in that of strenous effort and continuity in achieving a goal.

I would, therefore, like to express my gratitude to all the people who have contributed with their own experience to the writing of this thesis.

Allereerst alle patiënten die hebben deelgenomen aan de onderzoeken beschreven in dit proefschrift. Dank u wel voor jullie bereidwilligheid! Ik hoop dat, zoals beloofd, dit onderzoek inderdaad toekomstige patiënten zal helpen.

Voorts gaat mijn dank uit naar mijn promotor, Prof. Stockbrügger. Beste Reinhold, ik ben je zeer erkentelijk voor de begeleiding van dit project. Dankzij jouw scherpe en kritische denkwijze, waardevolle ideeën en kennis is dit proefschrift er gekomen. Onderzoek is inderdaad 'a glass of pearls', een feit dat ik ook van je geleerd heb.

Daarnaast wil ik mijn beide co-promotores bedanken. Wim Hameeteman, je hebt me altijd gestimuleerd om het verband tussen de wetenschappelijke en klinische betekenis te zoeken. Tijdens onze discussies om resultaten op papier te zetten vroeg je mij altijd 'Wat zijn de gevolgen van deze data voor een klinicus?' Bedankt voor al je inzet en bovenal voor de mentale steun.

Adriaan de Bruïne, voor de vele kennis en kunde over de wereld van cellen, Helicobacters en non-Helicobacters die je mij hebt gedoceerd 
ben ik je zeer dankbaar. Jouw tomeloze energie en enthousiasme hebben me altijd enorm gemotiveerd. Samen hebben we duizenden histologische coupes 'gecodeerd' om uiteindelijk deze fascinerende wereld te kunnen 'ontcijferen'. Bedankt!

Daisy Jonkers, beste Daisy, bedankt voor jouw begeleiding gedurende het hele traject van dit proefschrift. Je betrokkenheid en collegialiteit heb ik zeer gewaardeerd. Het belangrijkste is (denk ik) dat in onze discussies veel nieuwe ideeën contour hebben gekregen. Bedankt voor al je steun!

Ik wil alle leden van de beoordelingscommissie, Prof. C. Bruggeman, Prof. E. Kuipers, Prof. P. van den Brandt en Prof. J.W. Cohen Tervaert bedanken voor hun bereidheid dit proefschrift te lezen en te beoordelen.

Dear Prof. P. Sipponen, I would like to thank you for your participation in the Assessment Committee of this PhD thesis.

Uiteraad was in de beginperiode de steun van het personeel van de endoscopie-afdeling AZM essentieel! De endoscopisten Eric Schoon, Ton Vrij, Rob Adang, Robert Bragelman, Robert-Jan Brummer, Maurice Russel, Ger Koek en Ingrid Pladett dank ik hartelijk voor het nemen van de extra biopten voor mijn studie en met name voor de plezierige werksfeer en steun. De endoscopie-assistentes (Ria, Daisy, Meggie en Bertien) en de balie-medewerksters (Monique, Lucie en Andy) wil ik graag zeer bedanken voor hun inspanningen en prettige samenwerking.

Tijdens 'mijn reis' door de wereld van cellen en bacteriën was ik zeker verdwaald zonder 'de onmisbare oriëntatiekaarten' van de mensen van de afdelingen pathologie en microbiologie. In het bijzonder wil ik Margriet, Anniek en Andrea bedanken voor de hulp bij het kleuren van de coupes. Sjaak, Jan, Jon en Barnabas bedankt voor de hulp bij het verwerken van het histologische materiaal. Ellen Stobberingh, wil ik danken voor de goede begeleiding gedurende de voorbereidingsfase van deze studies. Ook Christel, Monique en Nancy, allemaal bedankt, het werken met jullie was zeer plezierig.

Prof. C. Lamers en Dr. 1. Biemond wil ik bedanken voor de bereidwilligheid om de serum gastrine- en pepsinogeenbepalingen uit te voeren, en tevens voor het waardevolle commentaar betreffende de hoofdstukken III, IV, en VII.

Dear Prof. G. Lundqvist and dear Prof. M. Stridsberg. I would like to thank you for the indispensable help with the measurement of serum chromogranin $A$, as well as for the prompt and valuable comments on the manuscripts described in chapters III, IV, and VII.

Ook wil ik een speciaal woord van dank richten tot Reini Bretveld. Voor de onmisbare steun bij de statistische analyses ben ik je zeer erkentelijk. Ik wens je veel succes met jouw promotie! René van Oerle, reuze bedankt voor de fraaie en snel gemaakte illustraties! 
Dank gaat ook uit naar mijn collega's binnen de werkgroep Gastroenterologie: AnneMarie, Frank, Ardi, Marc, Daisy, Ingrid, Martine, Dominique, Bertine en Michiel. ledereen bedankt voor de aangename werksfeer en steun. In het bijzonder wil ik Ardi bedanken voor de fijne collegialiteit en gezellige discussies over de wereld 'van binnen en van buiten'. Ik ben blij dat we uiteindelijk hebben besloten de (samen 'geconspireerde') stelling: 'Ik wil niks ter wereld veranderen, behalve de Nederlandse grammatica' weg te laten. Deze was...bijna niet te verdedigen! Bedankt voor alles Ar en veel succes met jouw promotie! Ik ben ook blij dat jij en Daisy mijn paranimfen wilden worden.

Ook wil ik Edith en Lilian bedanken voor alle behulpzaamheid tijdens deze studies.

Prof. $\mathrm{H}$. Hillen wil ik graag bedanken voor het vertrouwen in de goede afronding van dit proefschrift.

De medewerkers van de firma AstraPharmaceutica BV Nederland wil ik hartelijk bedanken voor de wetenschappelijke inzet en onmisbare financiële ondersteuning bij dit proefschrift. Daniëlle Dols, Els van Rooy Anja Geertsen, Robert-Kees Stad, hartelijk dank voor de uitstekende samenwerking.

Dear Prof. A. Walan, I am grateful that you accepted to participate in the thesis committee. Also, I would like to thank you for the longstanding scientific dialogue, which was of great value in the preparation of this thesis.

Dear Prof. C. O'Morain, I would like to thank you for the critical review and valuable scientific comments concerning chapter $V$ of this thesis.

Marie-Noëlle Janssen en Pamela Falger, hartelijk dank voor de Engelse correcties van dit proefschrift.

Tiny Wouters, ik dank je hartelijk voor de lay-out van dit boek!

In final, calatorind inapoi in timp, multumesc din suflet parintilor mei care mi-au cultivat intotdeauna dorinta de a studia.

Sebi, tie iti multumesc pentru intelegerea si echilibrul pe care mi le-ai daruit in toti acesti ani, si mai cu seama pentru surpriza unica de a descoperi intr-un 'omulet' intelepciunea si spiritul critic al unui 'om mare'.

Miki, de la tine am invatat ca stiinta (oricare ar fi numele ei) are un numitor comun: adevarul simplu, fundamental. Tu stii bine ca fara ajutorul tau nu as fi izbutit sa dezleg ecuatia cu multe necunoscute. Datorita voua pot pune acum PUNCT (temporar!) povestii fara sfirsit. 
Publications 


\section{Publications}

\section{ARTICLES}

- S. Sanduleanu, M. Stridsberg, D. Jonkers, W. Hameeteman, I. Biemond, Lundqvist, C. Lamers, R.W. Stockbrugger. "Serum gastrin and chromogranin A levels during medium- and long-term acid suppressive therapy: a case-control study". Aliment Pharmacol Ther 1999;13:145-53.

- S. Sanduleanu, D. Jonkers, A de Bruine, W. Hameeteman, R.W. Stockbrugger. "Non-H.pylori bacterial flora during acid-suppressive therapy: differential findings in gastric juice and gastric mucosa". Aliment Pharmacol \& Ther 2001:15(3):379-88.

- S. Sanduleanu, D. Jonkers, A de Bruine, W. Hameeteman, R.W. Stockbrugger. "Double gastric infection with H.pylori and non-H.pylori bacteria during acidsuppressive therapy: enhanced pro-inflammatory cytokine response and development of atrophic gastritis". Aliment Pharmacol \& Ther 2001;15:1163-75.

- S. Sanduleanu, D. Jonkers, A de Bruine, W. Hameeteman, R.W. Stockbrugger. "Changes in gastric mucosa and luminal environment during acid-suppressive therapy: a review in depth". Dig Liv Dis 2001 (in press).

- S. Sanduleanu, A. de Bruine, M. Stridsberg, D. Jonkers, I. Biemond, W. Hameeteman, G. Lundqvist, R.W. Stockbrugger. "Serum chromogranin A as a screening test for gastric enterochromaffin-like cell hyperplasia during acidsuppressive therapy". Eur J Clin Invest 2001 (accepted).

\section{ABSTRACTS}

S. Sanduleanu, M. Stridsberg, D. Jonkers, W. Hameeteman, G. Lundqvist, R. W. Stockbrugger. "Plasma chromogranin A levels during gastric acid suppressive therapy". Gastroenterology 1998;114 (supp/ 4):G1133.

- S. Sanduleanu, A de Bruine, M. Stridsberg, W. Hameeteman, J.W. Arends, G. Lundqvist, R.W. Stockbrugger. "Plasma chromogranin A is related to enterochromaffin-like (ECL) cell proliferation during medium- and long-term gastric acid inhibition". Gastroenterology 1998;114 (supp/ 4):G4813.

- S. Sanduleanu, A de Bruine, M. Stridsberg, I. Biemond, W. Hameeteman, G. Lundqvist, R.W. Stockbrugger. "Serum gastrin, chromogranin A and gastric fundic ECL cell hyperplasia during medium- and long-term acid inhibition". Digestion 1998;59 (supp/ 3):A 2144.

- S. Sanduleanu, A de Bruine, D. Jonkers, W. Hameeteman, R.W. Stockbrugger. "Increased serum interleukin-8 during profound acid inhibition reflects gastric mucosal atrophy". Gastroenterology 1999,116:A 1313.

- S. Sanduleanu, D. Jonkers, A de Bruine, W. Hameeteman, R.W. Stockbrugger. "Non-H.pylori bacterial flora in gastric juice and gastric mucosa of patients treated with gastric acid inhibition". Gut 2000; 47(suppl. III):A80.

- S. Sanduleanu, D. Jonkers, A de Bruine, W. Hameeteman, R.W. Stockbrugger. "Double infection of the stomach with H.pylori and non-H.pylori bacterial flora increases the expression of pro-inflammatory cytokines". Gut 2000;47(suppl. III): A110. 
- S. Sanduleanu, A. de Bruine, M. Stridsberg, D. Jonkers, I. Biemond, W. Hameeteman, G. Lundqvist, R.W. Stockbrugger. "Serum chromogranin A is a useful screening test for gastric enterochromaffin-like cell hyperplasia during acidsuppressive therapy". Gut 2000;47(suppl. III): A206.

- S. Sanduleanu, A. de Bruine, M. Stridsberg, D. Jonkers, I. Biemond, W. Hameeteman, G. Lundqvist, C. Lamers, R.W. Stockbrugger. "Prediction of atrophic body gastritis by serum markers: observational study" Proceedings 4th International Gastric Cancer Congress, New York 2001.

- S. Sanduleanu, D. Jonkers, A de Bruine, W. Hameeteman, R.W. Stockbrugger. "Double infection of the stomach with H.pylori and non-H.pylori bacteria: a risk factor for the development of atrophic gastritis during acid-suppressive therapy" distinguished award, Proceedings 4th International Gastric Cancer Congress, New York 2001.

- S. Sanduleanu, D. Jonkers, A de Bruine, W. Hameeteman, R.W. Stockbrugger. "Double infection of the stomach with H.pylori and non-H.pylori bacteria: a cause for the development of atrophic gastritis during acid-suppressive therapy? Neth $J$ Med 2001;58:A17.

- $\quad$ R.W. Stockbrugger, S. Sanduleanu, D. Jonkers, A de Bruine, W. Hameeteman. “ Get rid of H.pylori before you start a PPI" www. GastroHep.com.15-07-2000.

\section{COMMUNICATIONS}

- S. Sanduleanu, D. Jonkers, A de Bruine, W. Hameeteman, R.W. Stockbrugger. "Does double infection of the stomach with H.pylori and non-H.pylori bacteria accelerate the development of atrophic gastritis during acid-suppressive therapy?" (oral presentation, 8th European Gastroenterology Week 2000, Brussel).

- S. Sanduleanu, D. Jonkers, A de Bruine, W. Hameeteman, R.W. Stockbrugger. "The rapid development of atrophic gastritis during gastric acid inhibition is due to a combined gastric infection with H.pylori and non-H.pylori bacteria" (oral presentation, European Cancer Prevention Congress, Maastricht 2000).

- S. Sanduleanu, D. Jonkers, A de Bruine, W. Hameeteman, R.W. Stockbrugger. "Double gastric infection with H.pylori and non-H.pylori bacteria: a risk for the development of atrophic gastritis during acid-suppressive therapy?" (oral presentation, Dutch Society of Gastroenterology/ Hepatology Congress, Veldhoven 2000). 
Curriculum Vitae 


\section{Curriculum Vitae}

Silvia Sanduleanu was born on June 16, 1965 in Dorohoi, Romania. After finishing the High School of Mathematics and Physics 'Grigore Ghica' in Dorohoi (July 1984), she immediately started studying Medicine at the University of Medicine and Pharmacy from lasi. She graduated and obtained her medical bachelor degree in 1990 (Cum Laude). From 1990 to 1995 she was trained as a resident in Internal Medicine at the University Hospital in lasi (first rank at final examination). In February 1995 she was registered an internist in Romania, became a physician in charge, and was appointed to assistant professor at this university.

In June 1996 she received an EC grant to study at the Department of Internal Medicine, Division of Gastroenterology of the University Hospital Maastricht. She continued with the research work described in this thesis under the supervision of Prof. Dr. R.W. Stockbrügger. From October 1998 to June 1999 she worked as a resident in Internal Medicine at the University Hospital Maastricht, under the supervision of Prof. Dr. H. Hillen. She will continue further training in Gastroenterology.

Her research interest involves precancerous lesions of the gastrointestinal tract, with focus on chronic atrophic gastritis, gastric ECL hyperplasia, and colorectal polyps. 